INSTITUTO DE PESQUISAS ENERGÉTICAS E NUCLEARES AUTARQUIA ASSOCIADA À UNIVERSIDADE DE SÃO PAULO

Desenvolvimento de hidrogel nanoestruturado contendo complexo de papaína e ciclodextrina

Gustavo Henrique Costa Varca

Tese apresentada como parte dos requisitos para obtenção do Grau de Doutor em Ciências na Área de Tecnologia Nuclear Materiais

Orientador:

Prof. Dr. Ademar Benévolo Lugão

Versão corrigida

São Paulo

2014 


\section{Dedicatória}

\section{"IN MEMORIAN"}

Dedico esta tese à minha querida avó Mafalda Filomena Costa, eterna fonte de inspiração e força, sempre ao meu lado, mesmo após sua passagem, e à minha querida avó, Alice Antunes Varca. Aos guias espirituais Sebastião Mota de Melo e Raimundo Irineu Serra pelas belas lições.

Ao querido amigo Handerson Abbondanza Lima pela motivação e apoio. Ao Kleber Danilo e Marco Rogério pelos momentos que dividimos em vida. E ao Bruno Enrico Souza Pilan, grande amigo de infância. Um dia nos encontraremos novamente. 


\section{Agradecimentos aos familiares:}

Agradeço a Deus por tudo. A cada momento, vivendo na certeza de nunca seguir desamparado. Aos meus pais, Ângelo Márcio Antunes Varca e Maria Beatriz Camargo Costa Varca, pelo exemplo diário de pai e mãe, honestidade e carinho. Devo tudo a vocês e nada seria possível sem que tivessem dedicado suas vidas para garantir meu futuro.

Agradeço ao meu tio Pedro Camargo Costa e minha tia tessalonicense Eleni Michaelidou Costa que tornaram possível esta etapa de estudos em São Paulo, assim como os aprendizados e a convivência diária. Muito obrigado!

Ao meu tio Carlos Camargo Costa, verdadeiro mestre dos mestres, exemplo para a família e todos os amigos. Quando penso em um professor de verdade, me lembro de você, meu querido tio.

Ao meu irmão Marcelo Augusto Costa Varca, pelo exemplo de dedicação e esforço, e por todos os momentos que passamos juntos.

À Justine Paula Ramos de Oliveira, minha mulher, pela paciência e compreensão durante a redação da tese assim como nas viagens e no dia a dia, nos momentos mais difíceis. 


\section{Aos professores e pesquisadores:}

Ao meu orientador Prof. Dr. Ademar Benévolo Lugão pelo apoio e oportunidade, assim como todo o aprendizado frente a cada dificuldade.

À professora Dra. Patricia Santos Lopes por ter acreditado em mim desde a faculdade, quando tudo começou. Hoje, ao finalizar o doutorado, reconheço sua salutar influência em minha formação.

À professora Dra. Monica B. Mathor pelo apoio e compreensão nas horas mais difíceis, principalmente pelos conselhos, ombro amigo e discussões científicas.

Ao professor Dr. Newton Andréo Filho, pelo apoio e os ensinamentos desde a graduação; e ao professor Dr. Luiz Ricardo Goulart Filho, pela oportunidade de visita científica e parceria.

Aos poloneses, em especial o Dr. Sławomir Kadłubowsky, Dr. Piotr Ulanski e Dr. Janusz M. Rosiak, pelo treinamento e a oportunidade de estagiar em seu laboratório.

Ao Dr. Traian Zaharescu, amigo pessoal, professor e parceiro de pesquisa. Agradeço por sua amizade e por ser parte da família.

Ao Dr. Emílio Ruiz-Bucio por todos os ensinamentos, e acima de tudo, por ensinar a seus alunos que se ensina, sobretudo, com o exemplo. Meu muito obrigado!

Ao Dr. Mariano Grasselli pelo apoio, parceria e orientação.

Ao professor Élio Fernandes Más, por sempre ter me apoiado e acreditar em mim desde a graduação. Valeu pelo incentivo!

À Elizabeth S. R. Somessari e Carlos Gaia da Silveira pela irradiação das amostras.

À pesquisadora Dra. Yasko Kodama por sua atenção e parceria.

À Caroline Cristina Ferraz por sua amizade e parceria na pesquisa desde sempre. Muito obrigado por tudo! 
Ao Jorge Gabriel dos Santos Batista e ao Rodrigo Guimarães Queiroz, parceiros e amigos de experimento e do dia a dia. Valeu pela força, amizade e motivação.

Agradeço também as pesquisadoras Mayara Ingrid e Patrícia Terra pela atenção e relevante contribuição para conclusão da tese; a Gabriela G. Perossi, Bruna Melo Diniz, Diana Rodriguez Linares, Maria José Alves de Oliveira, Mara Tânia Alcântara e a todos os que colaboraram direta ou indiretamente com o desenvolvimento do projeto. 


\section{Às instituições e agências de fomento:}

Ao Instituto de Pesquisas Energéticas e Nucleares (IPEN-CNEN/SP) e à Universidade de São Paulo, pela infraestrutura disponível e o ambiente agradável de aprendizado.

À Fundação de Amparo à Pesquisa do Estado de São Paulo (FAPESP) pela bolsa de doutorado direto, essencial para o desenvolvimento do trabalho.

À Agencia Internacional De Energia Atômica (Internacional Atomic Energy Agency - IAEA) pelo apoio financeiro destinado a este trabalho.

À Associação Internacional de Irradiação (International Irradiation Association - iia) e ao Congresso de Radiação lonizante e Polímeros (lonizing Radiation and Polymers Symposium - IRaP) pelos prêmios científicos concedidos, bem como pela oportunidade de divulgar este trabalho em diversos países.

Ao Instituto de Química das Radiações Aplicadas (Institute of Applied Radiation Chemistry), em Lodz na Polônia, pela oportunidade de aprendizagem e realização de experimentos.

À Universidade Federal de Uberlândia - UFU, mais especificamente ao Laboratório de Nanobiotecnologia, pela oportunidade de realização de experimentos fundamentais para a tese e pela parceria científica. 
"O cientista não é o homem que fornece as verdadeiras respostas; é quem faz as verdadeiras perguntas".

Claude Lévi-Strauss 


\title{
DESENVOLVIMENTO DE HIDROGEL NANOESTRUTURADO CONTENDO COMPLEXO DE PAPAÍNA E CICLODEXTRINA
}

\author{
Gustavo Henrique Costa Varca
}

\section{RESUMO}

A papaína é uma enzima proteolítica empregada no debridamento e cicatrização de feridas. Contudo, problemas de estabilidade na forma farmacêutica, bem como reações alérgicas reportadas por pacientes submetidos à tratamentos com a enzima, culminaram na restrição aos produtos contendo papaína para uso tópico por órgãos regulatórios internacionais. Este trabalho objetivou desenvolver hidrogel nanoestruturado contendo complexo de papaína e ciclodextrina visando obter forma farmacêutica estável e eficaz como curativo dérmico, com redução da resposta imunológica. A síntese do hidrogel foi realizada combinando fenômenos de cristalização e/ou reticulação e esterilização simultânea induzida por radiação gama, de modo a promover nanoestruturação adequada da membrana para veiculação da papaína nativa e do complexo. O complexo e o produto final tiveram suas propriedades biológicas e físico-químicas avaliadas. $O$ hidrogel a base de PVA contendo complexo de papaína-ciclodextrina apresentou características adequadas para aplicação como curativo, além de apresentar indícios de redução na resposta imunológica e melhora na citocompatibilidade quando comparado à papaína nativa, isso devido ao encapsulamento molecular com a ciclodextrina e à alta retenção do complexo por parte da matriz. Por outro lado, a irradiação, não alterou o perfil citotóxico da enzima, mas acarretou leve diminuição em seu potencial imunogênico. O hidrogel se mostrou promissor para uso como curativo e demonstrou potencial redução nas reações adversas desencadeadas pelo uso da papaína.

Palavras-Chaves: Complexo de Papaína e Ciclodextrina, Hidrogel, Radiação ionizante, Imunogenicidade, Citotoxicidade. 


\title{
DEVELOPMENT OF A NANOSTRUCTURED HYDROGEL CONTAINING PAPAIN AND CYCLODEXTRIN COMPLEX
}

\author{
Gustavo Henrique Costa Varca
}

\begin{abstract}
Papain is a proteolytic enzyme applied for wound healing and debridement. However, stability issues as well as allergenic reactions reported by patients submitted to papain pharmaceutics led to restriction of papain containing products for topical use by international regulatory agencies. This work aimed the development of nanostructured hydrogel containing papain and cyclodextrin complex or papain in order to obtain stable and suitable pharmaceutical form as a wound dressing with reduced allergenic properties. The hydrogel synthesis was performed by combining freezing cycles and the simultaneous crosslinking and sterilization process promoted by gamma irradiation to achieve a nanostructured hydrogel for the loading of the papain and cyclodextrin complex. The biological and physical-chemical properties of the complex and the final product were assayed. The PVA based hydrogel containing cyclodextrin-papain complex presented desirable characteristics for wound dressing purposes. In addition, an in vitro shift in the immunological response and an increase in the cytocompatibility if compared to native papain were observed as a function of the molecular encapsulation with cyclodextrin. The process of irradiation was not capable of altering papain cytotoxicity, but conferred a slight decrease in the immunogenic properties. In conclusion, the developed hydrogel was promising as a novel papain containing dressing with potential reduced adverse reactions.
\end{abstract}

Key-Words: Papain and Cyclodextrin complex; Hydrogel; lonizing radiation, Immunogenicity, Cytotoxicity. 


\section{SUMÁRIO}

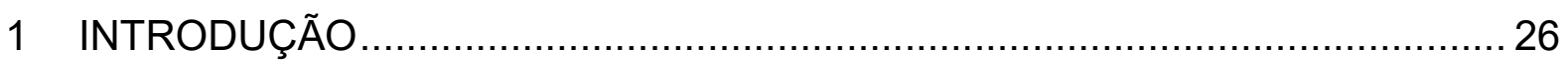

2 OBJETIVOS

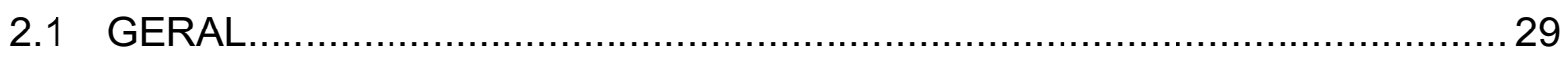

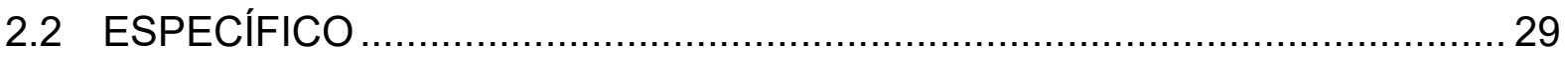

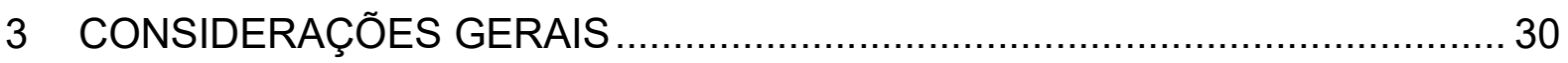

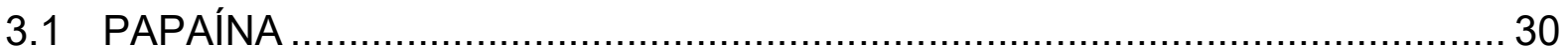

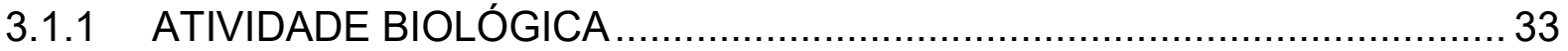

3.1.2 APLICAÇÕES FARMACÊUTICAS E BIOTECNOLÓGICAS ....................... 34

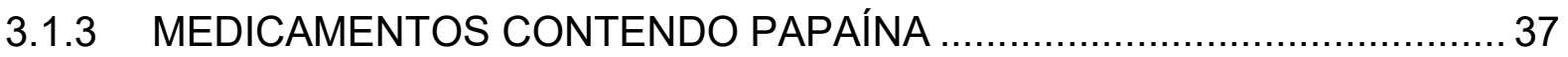

3.1.4 SISTEMAS DE ESTABILIZAÇÃO DA PAPAÍNA …................................. 39

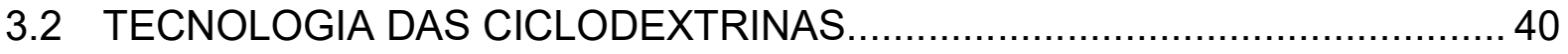

3.2.1 COMPLEXOS ENTRE CICLODEXTRINAS E PROTEÍNAS ….................. 42

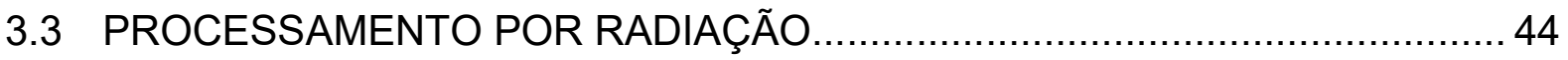

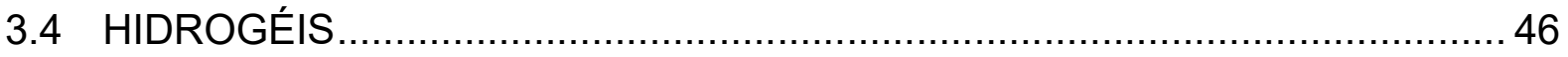

3.4.1 HIDROGÉIS PARA LIBERAÇÃO DE PROTEÍNAS .................................. 48

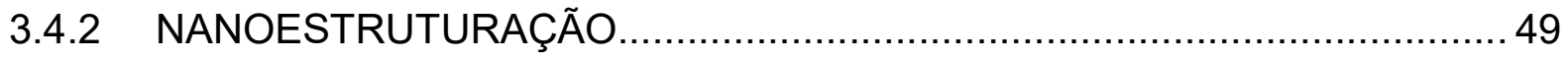

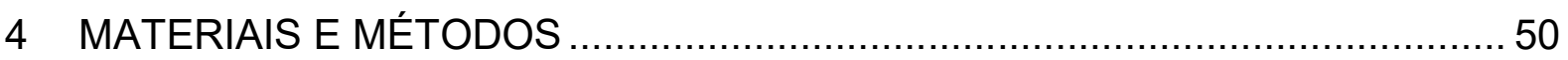

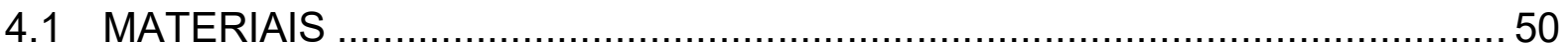

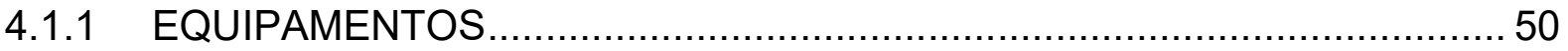

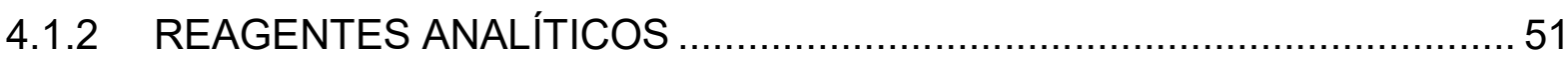

4.1.3 ANIMAIS, LINHAGENS CELULARES E MICROORGANISMOS ...............54

4.2 MÉTODOS 
4.2.1 DESENVOLVIMENTO DE COMPLEXO DE PAPAÍNA E CICLODEXTRINA

4.2.1.1 ESTUDOS COMPUTACIONAIS .55

4.2.1.2 DETERMINAÇÃO DOS PARÂMETROS FÍSICO-QUÍMICOS ADEQUADOS PARA COMPLEXAÇÃO 56

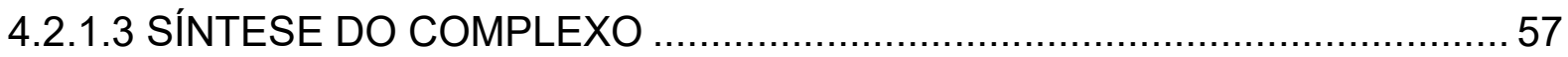

4.2.1.4 CARACTERIZAÇÃO FÍSICO-QUÍMICA DO COMPLEXO ........................ 57

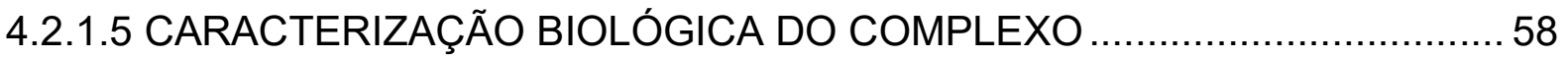

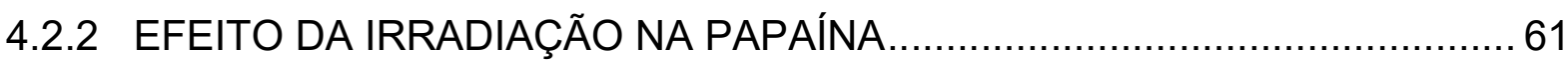

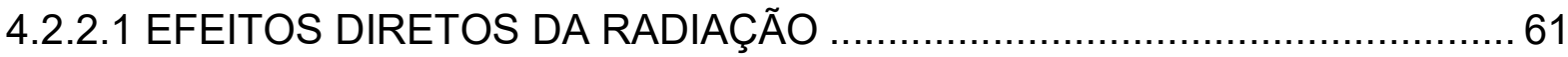

4.2.2.2 EFEITOS INDIRETOS DA RADIAÇÃO .............................................. 61

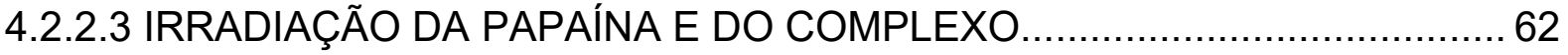

4.2.3 DESENVOLVIMENTO DO HIDROGEL CONTENDO COMPLEXO DE PAPAÍNA E CICLODEXTRINA ...................................................... 63

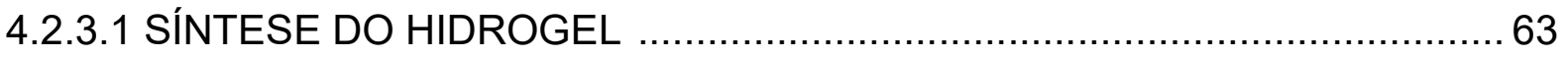

4.2.3.2 CARACTERIZAÇÃO DA FORMA FARMACÊUTICA ..............................6 66

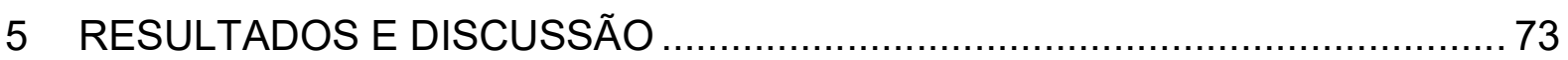

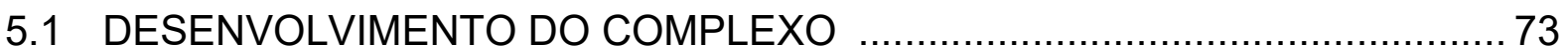

5.1.1 IMPLICAÇÕES DA ESTRUTURA PROTEICA NA FORMAÇÃO DO

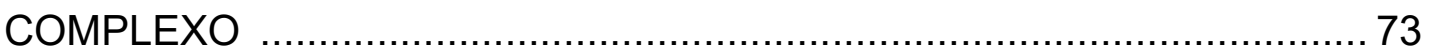

5.1.1.1 AVALIAÇÃO DA ESTRUTURA DA PAPAÍNA ....................................... 73

5.1.1.2 INTERAÇÃO PROTEÍNA SOLVENTE ............................................... 75

5.1.1.3 ÁREA ACESSÍVEL AO SOLVENTE FRACIONADA ............................. 78

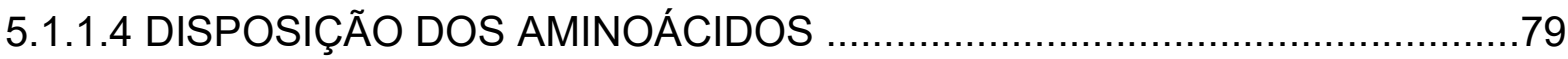

5.1.2 DETERMINAÇÃO DOS PARÂMETROS DE SÍNTESE DO COMPLEXO ... 87

5.1.3 OTIMIZACÃO DO COMPLEXO DE PAPAINA E CICLODEXTRINA ..........95

5.1.4 SÍNTESE DO COMPLEXO DE PAPAÍNA E CICLODEXTRINA ............... 96 
5.1.5.1 CITOTOXICIDADE

5.1.5.2 AVALIÇÃO DO POTENCIAL INFLAMATÓRIO E IMUNOGÊNICO 102

5.2 EFEITO DA IRRADIACÃO NA PAPAÍNA 111

5.2.1 EFEITOS DIRETOS DA IRRADIAÇÃO 111

5.2.2 EFEITOS INDIRETOS DA RADIAÇÃO 113

5.3 DESENVOLVIMENTO DO HIDROGEL 116

5.3.1 HIDROGEL DE PVP 116

5.3.2 HIDROGEL DE PVA 120

5.3.1.1 PROPRIEDADES DE INTUMESCIMENTO 122

5.3.1.2 FRAÇÃO GEL 124

5.3.1.3 DENSIDADE DE RETICULAÇÃO 125

5.3.1.4 VEICULAÇÃO DA PAPAÍNA E DO COMPLEXO 127

5.3.1.5 AVALIAÇÃO DA LIBERAÇÃO DO COMPLEXO PELO HIDROGEL 128

5.3.1.6 AVALIAÇÃO DO POTENCIAL CITOTÓXICO DO HIDROGEL 130

5.3.1.7 AVALIÇÃO DO POTENCIAL INFLAMATÓRIO E IMUNOGÊNICO 133

6 CONCLUSÃO 141

7 REFERÊNCIAS 143 


\section{LISTA DE ABREVIAÇÕES E SIGLAS}

A - Angstrom

BAPA - Cloridrato de benzoil DL-arginina $\rho$-nitroanilida

$\beta: C D$ - Beta-ciclodextrina

${ }^{\circ} \mathrm{C}$ - Grau Celsius

CAAE - Certificado de Apresentação para Apreciação Ética

CNEN/SP - Comissão Nacional de Energia Nuclear / São Paulo

COEP - Comitê de Ética em Pesquisa

CTR - Centro de Tecnologia das Radiações

D10 - Nomenclatura adotada para o meio de cultura DMEM acrescido de $10 \%$ de soro fetal bovino

Da - Dalton

dm- $\beta: C D$ - dimetil-beta-ciclodextrina

DMEM - Meio de Eagle modificado por Dulbecco (Dulbecco's Modified Eagle's Medium)

DMSO - Dimetilsulfóxido

$\mathbf{e}^{-}$aq - Elétron aquoso

EDTA - Ácido Etilenodiaminotetracético (Ethylenediaminetetraacetic Acid)

FDA - Food and Drug Administration

Gy - Gray

hp- $\beta: C D$ - hidroxipropil-beta-ciclodextrina

IAEA - Agência Internacional de Energia Atômica (International Atomic Energy Agency)

IFN- $\boldsymbol{\gamma}$ - Interferon Gamma 
IL - Interleucina

IPEN - Instituto de Pesquisas Energéticas e Nucleares

K- - Meio de cultura próprio para cultivo de queratinócitos isento de EGF

K+ - Meio de cultura próprio para cultivo de queratinócitos, acrescido de EGFa

kDa - Quilo Dalton

KGF - Fator de crescimento de queratinócitos (Keratinocyte growth factor)

m- $\beta: C D$ - Metil-beta-ciclodextrina

MEV - Microscópio eletrônico de varredura

MTT - brometo de 3-(4,5-dimetil-2-tiazolil)-2, 5-difenil-2H-tetrazólio

nm - Nanômetro

$\mathrm{OH}^{\bullet}$ - Radical Hidroxila

PVA - Álcool polivinílico

PBMC - Células Mononucleares do sangue periférico (Peripheral Blood Mononuclear Cells)

PEG - Polietilenoglicol

pH - Potencial hidrogeniônico

RPM - Rotações por minuto

TGF- $\boldsymbol{\beta}$ - Fator de transformação do crescimento beta

TNF- $\alpha$ - Fator de Necrose Tumoral Alfa (Tumor Necrosis Factor Alpha)

USP - Universidade de São Paulo

$\mu \mathbf{g}$ - Micrograma

$\mu \mathrm{L}-$ Microlitro

$\mu \mathrm{M}$ - Micromol

um - Micrômetro

UV - ultravioleta 


\section{LISTA DE FIGURAS}

FIGURA 1 - REPRESENTAÇÃO GRÁFICA DA MOLÉCULA DA PAPAÍNA E SUAS INTERAÇÕES

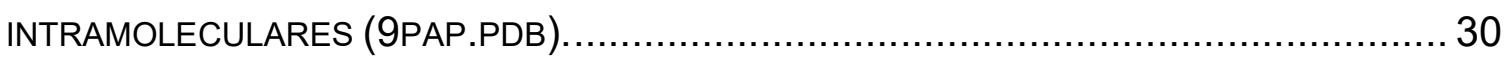

FIGURA 2 - SEQUÊNCIA DE AMINOÁCIDOS PRESENTES NA ESTRUTURA DA PAPAÍNA.

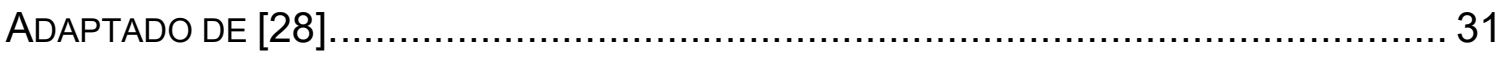

FIGURA 3 - DISTRIBUIÇÃO DOS AMINOÁCIDOS PRESENTES NA MOLÉCULA DE PAPAÍNA, DE ACORDO COM A POLARIDADE (9PAP.PDB), CONSIDERANDO QUE: A - RESÍDUOS POLARES (AZUL); B - TODOS OS RESÍDUOS; C - RESÍDUOS APOLARES (EM VERMELHO). 32

FIGURA 4 - DISTRIBUIÇÃO DOS AMINOÁCIDOS PRESENTES NA MOLÉCULA DE PAPAÍNA, DE ACORDO COM A CARGA (9PAP.PDB), CONSIDERANDO QUE: A - RESÍDUOS BÁSICOS, B RESÍDUOS NEUTROS (VERMELHO - APOLARES; AZUL - POLARES); C - RESÍDUOS ÁCIDOS.

FIGURA 5 - INTERAÇÃO ESPECÍFICA DA PAPAÍNA COM SUBSTRATO. ADAPTADO DE [35].... 33

FIGURA 6 - SELETIVIDADE E DIFERENÇA DA CLIVAGEM DE ANTICORPOS UTILIZANDO A PAPAÍNA E A PEPSINA. ADAPTADO DE [38].

FIGURA 7 - PAPAÍNA DE USO COMERCIAL (NEUROPAPAIN ${ }^{T M}$ - GELANTIS) ESPECÍFICA PARA DISSOCIAÇÃO DE CÉLULAS DE TECIDO NEURONAL. DISPONÍVEL EM [40]. 36

FIGURA 8 - SOLUÇÃO PADRONIZADA DE PAPAÍNA (ID-PAPAIN ${ }^{\circledR}$ ). DISPONÍVEL EM [41]...... 36

FIGURA 9 - POMADA CONTENDO PAPAÍNA, URÉIA E CLOROFILA (ALLANFILL ${ }^{\circledR}$ ). DISPONIVEL EM [42].

FIGURA 10 - EMULSÃO EM SPRAY CONTENDO PAPAÍNA E URÉIA (ACCUZYME ${ }^{\circledR}$ ) SE. DISPONÍVEL EM [43]. 37

FIGURA 11 - SUPLEMENTOS CONTENDO PAPAÍNA COMO AUXILIAR NA DIGESTÃO. DISPONÍVEL EM [45]. 38

FIGURA 12 - PAPAÍNA IMOBILIZADA EM AGAROSE COMERCIALMENTE DISPONÍVEL (IMMOBILIZED PAPAIN - THERMO SCIENTIFIC PIERCE). DISPONIVEL EM [52]. 39 
FIGURA 13 - REPRESENTAÇÃO GRÁFICA DA ESTRUTURA DAS CICLODEXTRINAS NATURAIS. ADAPTADO DE [54].

FIGURA 14 - ESQUEMA REPRESENTATIVO DA MOLÉCULA DE CICLODEXTRINA. ADAPTADO DE [53]. 41

FIGURA 15 - EXEMPLOS DE MODIFICAÇÕES REALIZADAS NAS B-CICLODEXTRINAS, CONSIDERANDO QUE: A - RADICAL HIDROXIPROPIL; B - RADICAL DIMETIL. 41

FIGURA 16 - ESQUEMA REPRESENTATIVO DA FORMAÇÃO DE COMPLEXOS ENTRE PROTEINAS GLOBULARES E CICLODEXTRINAS. 42

FIGURA 17 - AMINOÁCIDOS-ALVO DO ENCAPSULAMENTO MOLECULAR DAS CICLODEXTRINAS EM PROTEÍNAS GLOBULARES E PEPTÍDEOS. 43

FIGURA 18 - INTERAÇÃO ENTRE CICLODEXTRINAS E AMINOÁCIDOS, CONSIDERANDO QUE: A - FORMAÇÃO DOS COMPLEXOS DE INCLUSÃO MOLECULAR ENTRE AMINOÁCIDOS E CICLODEXTRINAS; B - FORÇA DE LIGAÇÃO ENTRE CICLODEXTRINA E OS AMINOÁCIDOSALVO.

FIGURA 19 - ESQUEMA REPRESENTATIVO DA RADIÓLISE DA ÁGUA. ADAPTADO DE [65] ... 45

FIGURA 20 - HIDROGÉIS À BASE DE PVP COMERCIALMENTE DISPONIVEIS PRODUZIDOS POR RADIAÇÃO (AQUA-GEL ${ }^{\circledR}$ DA KIKGEL) [70]. 47

FIGURA 21 - LENTE DE CONTATO CONSTITUÍDA DE HIDROGEL DE SILICONE [72] 47

FIGURA 22 - ESQUEMA DE PRODUÇÃO DOS HIDROGÉIS, CONSIDERANDO QUE: A - PREPARO DOS FILMES; B - CORTE DOS FILMES; C - MOLDAGEM DOS FILMES; D - TERMOFORMAGEM DOS BERÇOS; E - SOLUÇÃO DE POLÍMERO VERTIDA NO BERÇO PRONTO; F - SELAGEM A VÁCUO. 64

FIGURA 23 - REPRESENTAÇÃO GRÁFICA DA INTERAÇÃO PAPAÍNA-SOLVENTE, CONSIDERANDO QUE: A - SUPERFÍCIE ACESSIVEL AO SOLVENTE (CONSIDERA A ÁREA OBTIDA PELA SONDA DE 1,4 ANGSTRONS + O RAIO DE VAN DER WALLS); B - SUPERFÍCIE INACESSIVIEL POR SOLVENTE (TODA A ÁREA SITUADA DENTRO DOS LIMITES DA ÁREA OBTIDA POR UMA SONDA DE 1,4 ANGSTRONS). 75 
FIGURA 24 - REPRESENTAÇÃO GRÁFICA DA SUPERFÍCIE DE SOLVENTE (INTERFACE PAPAÍNASOLVENTE CORRESPONDENTE AOS LIMITES DA ÁREA OBTIDA POR UMA SONDA DE 1,4 ANGSTROMS).

FIGURA 25 - ÀREA ACESSIVEL POR SOLVENTE FRACIONADA OBTIDA PARA A MOLÉCULA DE PAPAÍNA (9PAP.PDB) UTILIZANDO O SOFTWARE VADAR.

FIGURA 26 - DISPOSIÇÃO E INTERAÇÃO DOS RESÍDUOS DE FENILALANINA PRESENTES NA PAPAÍNA COM O SOLVENTE, CONSIDERANDO QUE: A - DISTRIBUIÇÃO DOS RESÍDUOS; B SUPERFÍCIE MOLECULAR; C - SUPERFÍCIE INACESSIVEL POR SOLVENTE; D - ÁREA ACESSIVEL POR SOLVENTE. 800

FIGURA 27 - DISPOSIÇÃO E INTERAÇÃO DOS RESÍDUOS DE TRIPTOFANO PRESENTES NA PAPAÍNA COM O SOLVENTE, CONSIDERANDO QUE: A - DISTRIBUIÇÃO DOS RESÍDUOS; B SUPERFÍCIE MOLECULAR; C - SUPERFÍCIE INACESSIVEL POR SOLVENTE; D - ÁREA ACESSIVEL POR SOLVENTE.

FIGURA 28 - DISPOSIÇÃO E INTERAÇÃO DOS RESÍDUOS DE TIROSINA PRESENTES NA PAPAÍNA COM O SOLVENTE, CONSIDERANDO QUE: A - DISTRIBUIÇÃO DOS RESÍDUOS; B SUPERFÍCIE MOLECULAR, C - SUPERFÍCIE INACESSIVEL POR SOLVENTE; D - ÁREA ACESSIVEEL POR SOLVENTE. 84

FIGURA 29 - DISPOSIÇÃO E INTERAÇÃO DOS RESÍDUOS DE HISTIDINA PRESENTES NA PAPAÍNA COM O SOLVENTE, CONSIDERANDO QUE: A - DISTRIBUIÇÃO DOS RESÍDUOS; B SUPERFÍCIE MOLECULAR; C - SUPERFÍCIE INACESSIVEEL POR SOLVENTE; D - SUPERFÍCIE ACESSÍVEL POR SOLVENTE. 85

FIGURA 30 - INTERAÇÃO DOS RESÍDUOS DE PROLINA PRESENTES NA PAPAÍNA COM O SOLVENTE, CONSIDERANDO QUE: A - DISTRIBUIÇÃO DOS RESÍDUOS; B - SUPERFÍCIE MOLECULAR; C - SUPERFÍCIE INACESSIVEL POR SOLVENTE; D - SUPERFICIE ACESSIVEL POR SOLVENTE.

FIGURA 31 - ATIVIDADE ENZIMÁTICA DA PAPAÍNA EM FUNÇÃO DA ADIÇÃO DE CONCENTRAÇÕES DISTINTAS DE CICLODEXTRINA (1-10 NMOL-1) APÓS SOLUBILIZAÇÃO DOS COMPOSTOS $(\mathrm{T}=0)$. 88 
FIGURA 32 - ATIVIDADE ENZIMÁTICA DA PAPAÍNA EM FUNÇÃO DA ADIÇÃO DE CONCENTRAÇÕES DISTINTAS DE CICLODEXTRINA (25-200 NMOL-1) APÓS SOLUBILIZAÇÃO DOS COMPOSTOS $(\mathrm{T}=0)$.

FIGURA 33 - ATIVIDADE RELATIVA DA PAPAÍNA (PAPAÍNA ISOLADA CONSIDERADO 100\%) EM FUNÇÃO DA CONCENTRAÇÃO DE CICLODEXTRINA APÓS SOLUBILIZAÇÃO DOS COMPOSTOS. 90

FIGURA 34 - ESPECTRO DE FLUORESCÊNCIA (300-400 NM) DOS COMPLEXOS DE PAPAÍNA E CICLODEXTRINA APÓS SOLUBILIZAÇÃO DOS COMPOSTOS (T=0). 91

FIGURA 35 - ESPECTRO DE EMISSÃO (300-400 NM) DOS COMPLEXOS DE PAPAÍNA E CICLODEXTRINA EM DIFERENTES PROPORÇÕES MOLARES APÓS SOLUBILIZAÇÃO DOS COMPOSTOS $(\mathrm{T}=0)$. 92

FIGURA 36 - ESPECTRO DE FLUORESCÊNCIA DA PAPAÍNA E CICLODEXTRINA APÓS 24 HORAS DE INCUBAÇÃO. 93

FIGURA 37 - ATIVIDADE ENZIMÁTICA DOS COMPLEXOS DE PAPAÍNA E B-CICLODEXTRINA (125 ПMOL) APÓS 24 HORAS DE INCUBAÇÃO. 93

FIGURA 38 - ESPECTRO DE FLUORESCÊNCIA DE COMPLEXO DE PAPAÍNA E CICLODEXTRINA EM DIFERENTES PROPORÇÕES MOLARES NO TEMPO DE 48 HORAS. 94

FIGURA 39 - ESPECTROS DE FLUORESCÊNCIA DOS COMPLEXOS DE PAPAÍNA E DIFERENTES CICLODEXTRINAS APÓS 24 HORAS DE INCUBAÇÃO. 96

FIGURA 40 - COMPLEXO DE PAPAÍNA E B-CD DESENVOLVIDO, CONSIDERANDO QUE: A EMBALAGEM CONTENDO 1 G DO COMPLEXO; B - COMPLEXO LIOFILIZADO. 97

FIGURA 41 - ENSAIO DE VIABILIDADE CELULAR APÓS CONTATO DA PAPAÍNA E COMPLEXO EM QUERATINÓCITOS HUMANOS, UTILIZANDO COMO CORANTE VITAL O MTS. 98

FIGURA 42 - AVALIAÇÃO DA CITOTOXICIDADE DA PAPAÍNA EM PBMC APÓS 24 HORAS DE CONTATO. 100

FIGURA 43 - AVALIAÇÃO DA CITOTOXICIDADE DA PAPAÍNA EM PBMC APÓS 72 HORAS DE CONTATO 100 
FIGURA 44 - AVALIAÇÃO DA CITOTOXICIDADE DA PAPAÍNA COMPLEXADA COM B-CD EM PBMC APÓS 24 HORAS DE CONTATO. 101

FIGURA 45 - AVALIAÇÃO DA CITOTOXICIDADE DA PAPAÍNA EM PBMC APÓS 72 HORAS DE CONTATO. 102

FIGURA 46 - INTERAÇÃO PAPAÍNA-ANTICORPO POR MÉTODO DE ELISA DA PAPAÍNA NATIVA, IRRADIADA (10 KGY) E COMPLEXO DE PAPAÍNA E B-CD. ${ }^{* * *}=\mathrm{P}<0,0001$ 103

FIGURA 47 - AVALIAÇÃO DA LIGAÇÃO PAPAÍNA-ANTICORPO POR MÉTODO DE ELISA DOS COMPLEXOS DE PAPAÍNA E DIFERENTES CICLODEXTRINAS. *** ${ }^{*} \mathrm{P}<0,0001$ 104

FIGURA 48 - DOSAGENS DE IL2 PRODUZIDAS POR ESPLENÓCITOS MURINOS EXPOSTOS À PAPAÍNA PURA (PP), PAPAÍNA IRRADIADA (IP) E O COMPLEXO DE PAPAíNA E BCICLODEXTRINA (P-BC), REALIZADA POR CITOMETRIA DE FLUXO USANDO O KIT CBA... 106

FIGURA 49 - DOSAGENS DE IL6 PRODUZIDAS POR ESPLENÓCITOS MURINOS EXPOSTOS À PAPAÍNA PURA (PP), PAPAÍNA IRRADIADA (IP) E O COMPLEXO DE PAPAÍNA E BCICLODEXTRINA (P-BC), REALIZADA POR CITOMETRIA DE FLUXO USANDO O KIT CBA... 107

FIGURA 50 - DOSAGENS DE IFNY PRODUZIDAS POR ESPLENÓCITOS MURINOS EXPOSTOS À PAPAÍNA PURA (PP), PAPAÍNA IRRADIADA (IP) E O COMPLEXO DE PAPAÍNA E BCICLODEXTRINA (P-BC), REALIZADA POR CITOMETRIA DE FLUXO USANDO O KIT CBA... 108

FIGURA 51 - DOSAGENS DE TNFA PRODUZIDAS POR ESPLENÓCITOS MURINOS EXPOSTOS À PAPAÍNA PURA (PP), PAPAÍNA IRRADIADA (IP) E O COMPLEXO DE PAPAÍNA E BCICLODEXTRINA (P-BC), REALIZADA POR CITOMETRIA DE FLUXO USANDO O KIT CBA... 108

FIGURA 52 - DOSAGEM DE IL 17A PRODUZIDAS POR ESPLENÓCITOS MURINOS EXPOSTOS À PAPAÍNA PURA (PP), PAPAÍNA IRRADIADA (IP) E O COMPLEXO DE PAPAÍNA E BCICLODEXTRINA (P-BC), REALIZADA POR CITOMETRIA DE FLUXO USANDO O KIT CBA... 109

FIGURA 53 - DOSAGENS DE IL4 PRODUZIDAS POR ESPLENÓCITOS MURINOS EXPOSTOS À PAPAÍNA PURA (PP), PAPAÍNA IRRADIADA (IP) E O COMPLEXO DE PAPAÍNA E BCICLODEXTRINA (P-BC), REALIZADA POR CITOMETRIA DE FLUXO USANDO O KIT CBA... 110 
FIGURA 54 - DOSAGENS DE IL10 PRODUZIDAS POR ESPLENÓCITOS MURINOS EXPOSTOS À PAPAÍNA PURA (PP), PAPAÍNA IRRADIADA (IP) E O COMPLEXO DE PAPAíNA E BCICLODEXTRINA (P-CB), REALIZADA POR CITOMETRIA DE FLUXO USANDO O KIT CBA... 110

FIGURA 55 - ESPECTRO DE ABSORÇÃO NO UV-VIS DO ADUTO PAPAÍNA-OH• DETERMINADO POR RADIÓLISE DE PULSO EM ATMOSFERA DE N2O. PULSO DE 7 NS, 20 GY POR PULSO E $\wedge=290$ A 500 NM. 113

FIGURA 56 - DETERMINAÇÃO DA CONSTANTE DE REAÇÃO DO ADUTO PAPAÍNA-OH• POR RADIÓLISE DE PULSO EM ATMOSFERA DE N2O. PULSO DE 7 NS, 20 GY POR PULSO E $\Lambda=330$ NM. 114

FIGURA 57 - DETERMINAÇÃO DA CONSTANTE DE REAÇÃO DO ADUTO PAPAÍNA - E-'AQ. POR RADIÓLISE DE PULSO. PULSO DE 7 NS, 20 GY POR PULSO E $\Lambda=720$ NM. 115

FIGURA 58 - HIDROGEL DE PVP DESENVOLVIDO. 116

FIGURA 59 - MORFOLOGIA DOS HIDROGÉIS DESENVOLVIDOS A BASE DE PVP, CONSIDERANDO QUE: A - $6 \%$ DE PVP; B - $15 \%$ DE PVP. 118

FIGURA 60 - MICROSCOPIA ELETRÔNICA DOS HIDROGÉIS À BASE DE PVP, CONSIDERANDO QUE: A - 3\% DE PEG; B - $5 \%$ DE PEG; C - 3\% DE PEG NA PRESENÇA DE PAPAÍNA (0,5\%, P/P) COM AUMENTO DE 1000X; D - COM AUMENTO DE 10.000X NA PRESENÇA DE PAPAÍNA $0,5 \%(P / P)$. 119

FIGURA 61 - PREPARO E EMBALAGEM DOS HIDROGÉIS A BASE DE PVA CONTENDO PAPAÍNA E O COMPLEXO DE PAPAÍNA E B-CICLODEXTRINA, CONSIDERANDO QUE: A - DISPOSIÇÃO DAS SOLUÇÕES POLIMÉRICAS NAS EMBALAGENS; B - HIDROGÉIS ENFORMADOS; C E D HIDROGÉIS DISPOSTOS NA EMBALAGEM FINAL PARA ACONDICIONAMENTO. 121

FIGURA 62 - HIDROGEL CONTENDO O COMPLEXO DE PAPAÍNA E B-CICLODEXTRINA DESENVOLVIDO SENDO MANUSEADO, CONSIDERANDO QUE: A - AO INÍCIO DA REMOÇÃO DA PLACA; B - REMOÇÃO QUASE COMPLETA. 121

FIGURA 63 - HIDROGEL DESENVOLVIDO SENDO APLICADO, CONSIDERANDO QUE: A - NA MÃO; B - NO ANTEBRAÇO. 122 
FIGURA 64 - AVALIAÇÃO DA DISTRIBUIÇÃO DAS PROTEÍNAS NO HIDROGEL CONTENDO COMPLEXO DE PAPAÍNA E B-CICLODEXTRINA DESENVOLVIDO

FIGURA 65 - PERFIL DE LIBERAÇÃO DOS HIDROGÉIS À BASE DE PVA

FIGURA 66 - AVALIAÇÃO DA BIOATIVIDADE DOS HIDROGÉIS DESENVOLVIDOS 7 DIAS APÓS IRRADIAÇÃO. 130

FIGURA 67 - ENSAIO DE CITOTOXICIDADE DOS HIDROGÉIS À BASE DE PVA EM CONTATO DIRETO COM CÉLULAS MONONUCLEARES DO SANGUE PERIFÉRICO. 131

FIGURA 68 - ENSAIO DE CITOTOXICIDADE DAS EXTRAÇÕES DOS HIDROGÉIS À BASE DE PVA COM CÉLULAS MONONUCLEARES DO SANGUE PERIFÉRICO. 131

FIGURA 69 - ENSAIO DE CITOTOXICIDADE DAS EXTRAÇÕES DOS HIDROGÉIS À BASE DE PVA COM CÉLULAS MONONUCLEARES DO SANGUE PERIFÉRICO. 132

FIGURA 70 - DOSAGEM DE IL2 PRODUZIDAS POR ESPLENÓCITOS MURINOS EXPOSTOS AO HIDROGEL E SUAS EXTRAÇÕES, REALIZADA POR CITOMETRIA DE FLUXO USANDO O KIT CBA. 133

FIGURA 71 - DOSAGEM DE IL6 PRODUZIDAS POR ESPLENÓCITOS MURINOS EXPOSTOS AO HIDROGEL E SUAS EXTRAÇÕES, REALIZADA POR CITOMETRIA DE FLUXO USANDO O KIT CBA.

FIGURA 72 - DOSAGEM DE IFNY PRODUZIDAS POR ESPLENÓCITOS MURINOS EXPOSTOS AO HIDROGEL E SUAS EXTRAÇÕES, REALIZADA POR CITOMETRIA DE FLUXO USANDO O KIT CBA.

FIGURA 73 - DOSAGEM DE TNFA, PRODUZIDAS POR ESPLENÓCITOS MURINOS EXPOSTOS AO HIDROGEL E SUAS EXTRAÇÕES, REALIZADA POR CITOMETRIA DE FLUXO USANDO O KIT CBA. 135

FIGURA 74 - DOSAGEM DE IL10 PRODUZIDAS POR ESPLENÓCITOS MURINOS EXPOSTOS AO HIDROGEL E SUAS EXTRAÇÕES, REALIZADA POR CITOMETRIA DE FLUXO USANDO O KIT CBA. 
FIGURA 75 - AVALIAÇÃO DAS PROPRIEDADES ANTIMICROBIANAS DOS HIDROGÉIS DE PVA CONTENDO PAPAÍNA, COMPLEXO DE PAPAÍNA E B-CICLODEXTRINA FRENTE A CEPA DE ESCHERICHIA COLI (ATCC 8739) EM MEIO TSB UTILIZANDO MÉTODO DE DIFUSÃO EM DISCO. 136

FIGURA 76 - AVALIAÇÃO DAS PROPRIEDADES ANTIMICROBIANAS DOS HIDROGÉIS DE PVA CONTENDO PAPAÍNA E COMPLEXO DE PAPAÍNA E B-CICLODEXTRINA FRENTE A CEPA DE PSEUDOMONAS AERUGINOSA (ATCC 9027) EM MEIO TSB UTILIZANDO MÉTODO DE DIFUSÃO EM DISCO. 137

FIGURA 77 - AVALIAÇÃO DAS PROPRIEDADES ANTIMICROBIANAS DOS HIDROGÉIS DE PVA CONTENDO PAPAÍNA E COMPLEXO DE PAPAÍNA E B-CICLODEXTRINA FRENTE A CEPA DE STAPHYLOCOCCUS AUREUS (ATCC 6538). 138

FIGURA 78 - AVALIAÇÃO DAS PROPRIEDADES ANTIMICROBIANAS DOS HIDROGÉIS FRENTE À CEPA DE CANDIDA ALBICANS (ATCC 10231).... 138

FIGURA 79 - MICROGRAFIA OBTIDA POR MICROSCOPIA ÓPTICA (AUMENTO DE 1000X) DO CONTROLE DE FIBROBLASTOS UTILIZADOS PARA O TESTE DE ADESÃO CELULAR, CONSIDERANDO QUE: A - CAMPO ESCURO; B - CAMPO CLARO. 139

FIGURA 80 - MICROGRAFIA OBTIDA POR MICROSCOPIA ÓPTICA DO HIDROGEL DE PVA SEM PAPAÍNA APÓS 24 HORAS DE CONTATO COM AS CÉLULAS BALB/C 3T3 PARA O TESTE DE ADESÃO CELULAR, CONSIDERANDO QUE: A - UTILIZANDO AUMENTO DE 1000X; B UTILIZANDO AUMENTO DE 4000X. 140

FIGURA 81 - MICROGRAFIA OBTIDA POR MICROSCOPIA ÓPTICA (AUMENTO DE 1500X) DO HIDROGEL À BASE DE PVA APÓS 24 HORAS DE CONTATO COM AS CÉLULAS BALB/C 3T3 PARA O TESTE DE ADESÃO CELULAR, CONSIDERANDO QUE: A - HIDROGEL COM PAPAíNA; B - HIDROGEL CONTENDO O COMPLEXO. 140 


\section{LISTA DE TABELAS}

TABELA 1 - RESUMO DAS PRINCIPAIS APLICAÇÕES INDUSTRIAIS DA PAPAÍNA E OUTRAS CISTEÍNO-PROTEASES.

TABELA 2 - FORMULAÇÕES-BASE DO HIDROGÉIS À BASE DE PVP. 64

TABELA 3 - FORMULAÇÕES DOS HIDROGÉIS PARA VEICULAÇÃO DO COMPLEXO À BASE DE PVA. 666

TABELA 4 - DISTRIBUIÇÃO DAS SUBESTRUTURAS PROTEICAS NA MOLÉCULA DE PAPAÍNA.73

TABELA 5 - LIGAÇÕES DE HIDROGÊNIO PRESENTES NA ESTRUTURA DA PAPAÍNA. 74

TABELA 6 - VALORES CALCULADOS E TEÓRICOS PARA OS ÂNGULOS DIÉDRICOS PRESENTES NA ESTRUTURA DA PAPAÍNA. 74

TABELA 7 - ÁREA DE SUPERFÍCIE ACESSÍVEL POR SOLVENTE DA MOLÉCULA DE PAPAÍNA.77

TABELA 8 - ÁREA DE SUPERFÍCIE ACESSÍVEL POR SOLVENTE PARA A CADEIA LATERAL

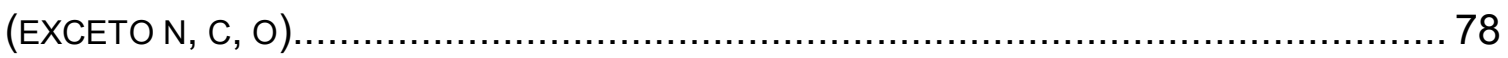

TABELA 9 - VOLUME CALCULADO DA MOLÉCULA DE PAPAÍNA. 78

TABELA 10 - ANÁLISE ESTRUTURAL DOS RESÍDUOS DE FENILALANINA PRESENTES NA PAPAÍNA. 81

TABELA 11 - ANÁLISE ESTRUTURAL DOS RESÍDUOS DE TRIPTOFANO. 82

TABELA 12 - ANÁLISE ESTRUTURAL DOS RESÍDUOS DE TIROSINA PRESENTES NA MOLÉCULA DA PAPAÍNA. 83

TABELA 13 - ANÁLISE ESTRUTURAL DOS RESÍDUOS DE HISTIDINA PRESENTES NA MOLÉCULA DA PAPAÍNA. 86

TABELA 14 - ANÁLISE ESTRUTURAL DOS RESÍDUOS DE PROLINA PRESENTES NA PAPAÍNA. 86 
TABELA 15 - VALORES DE ATIVIDADE RELATIVA (USP.U/ML) REGISTRADOS EM CADA MEIO FRENTE A DOSE DE RADIAÇÃO ESPECIFICADA............................................ 112

TABELA 16 - CARACTERIZAÇÃO DOS HIDROGÉIS À BASE DE PVP DESENVOLVIDOS. ...... 117

TABELA 17 - AVALIAÇÃO DAS PROPRIEDADES DE INTUMESCIMENTO MÁXIMO DOS HIDROGÉIS DESENVOLVIDOS À BASE DE PVA.......................................................... 123

TABELA 18 - AVALIAÇÃO DA FRAÇÃO GEL DOS HIDROGÉIS À BASE DE PVA DESENVOLVIDOS.

TABELA 19 - VALORES DE DENSIDADE DE RETICULAÇÃO OBTIDA PARA OS HIDROGÉIS À BASE DE PVA DESENVOLVIDOS PARA VEICULAÇÃO DO COMPLEXO. 126 


\section{LISTA DE EQUAÇÕES}

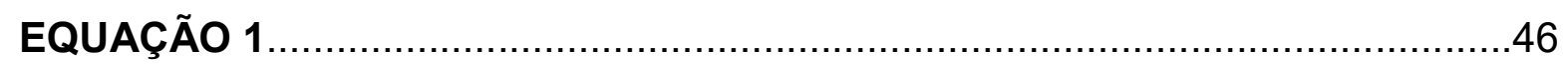

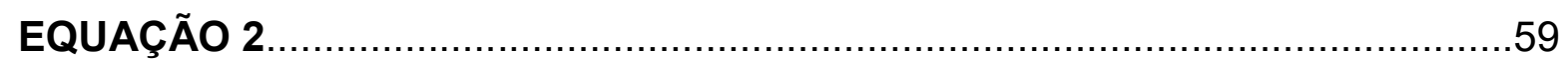

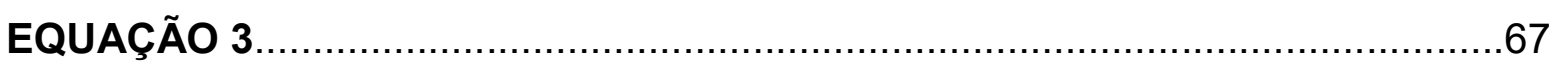

EQUAÇÃO 4

EQUAÇÃO 5

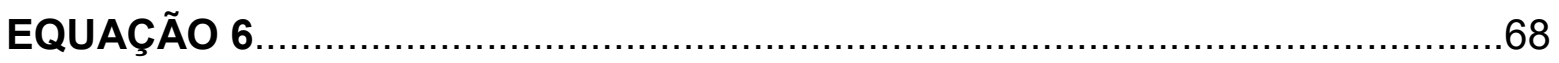

EQUAÇÃO 7

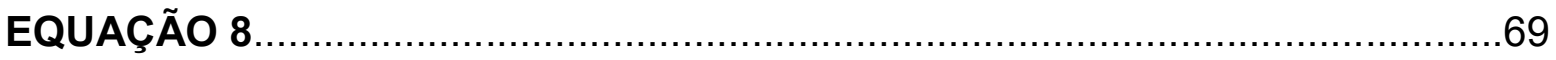




\section{INTRODUÇÃO}

A produção de medicamentos contendo enzimas vem sofrendo constante expansão, graças a seu amplo potencial terapêutico, constituindo novos recursos farmacológicos obtidos de fontes naturais. Tais produtos possuem diversas aplicações, como auxiliares na absorção cutânea [1] e agentes debridantes no tratamento de feridas e escaras [2], dentre outros.

O tratamento de feridas e escaras desafia os pesquisadores a desenvolverem sistemas de fácil aplicação capazes de conferir maior adesão e melhor desempenho do produto, com redução de custos e de tempo de uso, considerando o limitado número de medicamentos disponíveis. Os principais procedimentos empregados atualmente para tratar tais condições são restritos à utilização de agentes debridantes [3], e procedimentos cirúrgicos [4], dificultando assim o tratamento dos pacientes.

Enzimas proteolíticas, como a papaína e a bromelina são capazes de digerir o tecido necrosado, facilitando o acesso de células saudáveis à área afetada e, portanto, vêm sendo exploradas para aplicação em tratamentos domiciliar e hospitalar [2]. Embora sua eficácia após uso contínuo por alguns dias seja conhecida [4], estas enzimas são sensíveis às alterações de $\mathrm{pH}$, temperatura e agitação dentre outros fatores [5], os quais inviabilizam sua veiculação em determinadas formas farmacêuticas, que apresentam, por sua vez, baixa estabilidade.

A busca por novas formas farmacêuticas que forneçam ambiente adequado, capaz de promover maior estabilidade biológica e, consequentemente, proporcionar ao usuário garantia de utilização de medicamento ativo e eficaz, é de grande relevância industrial e para os pacientes em geral.

A papaína é utilizada no tratamento de escaras por reduzir o crescimento bacteriano e a formação de exsudatos, induzir a formação de grânulos e digerir o tecido necrosado [6]. Contudo, além de problemas relacionados à estabilidade enzimática, a Food and Drug Administration (FDA) impôs restrições aos produtos para uso tópico contendo papaína, em virtude das reações adversas graves reportadas, como reações anafiláticas, e hipersensibilidades severas, observadas em pacientes submetidos ao uso destes produtos [7]. Tais implicações tornam relevante a busca 
por alternativas para a resolução do problema e por medicamentos adequados, ampliando os recursos terapêticos e explorando o potencial dessa enzima.

Esta protease é veiculada em bases dermatológicas comuns, como emulsões e géis, e na forma extemporânea, devido à sensibilidade da própria enzima, que hidrolisa facilmente, expondo seu sítio ativo, e consequentemente, causando perda da atividade enzimática [8]. No entanto, estas formas farmacêuticas ainda não são capazes de manter a estabilidade por muito tempo, resultando em um produto final de curto prazo de validade.

Na busca pela estabilização e por formas farmacêuticas avançadas para a veiculação da papaína, diversos estudos vêm sendo realizados visando a ligação da enzima à matrizes poliméricas por meio de imobilização [9], ligações com metais [10], uso da ureia [11] e uso de carboidratos [12], dentre outras técnicas.

Os hidrogéis são uma forma farmacêutica útil para o tratamento de feridas e escaras, cujo emprego oferecer vantagens frente às formas convencionais de curativos, por permitir o controle de suas propriedades mecânicas específicas e de sua estrutura, além de promover a liberação controlada de ativos [13].

A polivinilpirrolidona (PVP) e o polivinil álcool (PVA) são exemplos de polímeros utilizados na produção de hidrogéis com baixos níveis de toxicidade e excelente biocompatibilidade $[14,15]$. Ambos são frequentemente empregados em sistemas de liberação controlada e apresentam características adequadas para a aplicação em feridas e escaras, bem como para a veiculação da papaína.

O desenvolvimento de nanoestrutura controlada num hidrogel é capaz de promover uma cinética específica de liberação do princípio ativo e de controlar as propriedades físicas do material, permitindo adequá-lo para aplicações ainda mais específicas [16]. Portanto, a técnica se demonstra útil para promover a liberação controlada da papaína e obter um produto com melhores propriedades.

A exposição à radiação gama, técnica adotada para formação do hidrogel, é eficaz na redução da imunogenicidade de venenos, derivados proteicos e alimentos [17], por meio de modificações causadas na estrutura, modulando, assim, o reconhecimento do material pelo organismo, além de causar a destruição de patógenos e microrganismos deteriorantes [18]. Adicionalmente, a irradiação 
promove a esterilização do produto, essencial para aplicação em feridas, e a reticulação das moléculas poliméricas, formando uma porção insolúvel denominada gel [19].

O emprego da radiação permite ainda a realização desse processo a frio e na embalagem final, minimizando a degradação enzimática frente à esterilização por calor ou por óxido de etileno e a manipulação humana do produto durante a produção. Contudo, a irradiação também é capaz de influir na estabilidade de compostos proteicos e causar degradação, devido aos efeitos secundários da radiação.

Considerando a possível degradação enzimática decorrente da síntese do hidrogel que contém a enzima, se faz necessária a escolha de um estabilizante adequado. A utilização de ciclodextrinas (CDs) para a formação de um complexo com a papaína, em particular, pode ser ferramenta útil para promover a estabilização, podendo ainda ocasionar alterações na sua solubilidade e melhora na estabilidade térmica, conforme observado em fármacos de diversas classes [20,21] e proteínas $[22,23,24]$. A formação do complexo com a ciclodextrina poderia acarretar tais efeitos, além de promover a manutenção da estabilidade da papaína, conferindo proteção aos resíduos complexados e à estrutura característica da enzima, auxiliando na preservação, integridade estrutural e consequentemente na atividade biológica da enzima.

A formação de complexos de ciclodextrina com papaína já foi alvo de estudo anteriormente, no qual foi avaliada a influência da ciclodextrina (CD) no perfil térmico e na citotoxicidade do complexo, fornecendo evidências preliminares do potencial do emprego das ciclodextrinas na melhora da estabilidade térmica e na citocompatibilidade da papaína [25].

De maneira mais específica, a complexação da papaína com ciclodextrina visa a promover sua estabilidade e reduzir sua imunogenicidade, enquanto a nanoestruturação da membrana de hidrogel tem o propósito de adequar o perfil de liberação às diferentes necessidades terapêuticas e, também, proporcionar resistência mecânica adequada da membrana às necessidades de um paciente imobilizado. O emprego da radiação ionizante, essencial para formação do hidrogel e esterilização, pode ainda vir a contribuir para a redução da imunogenicidade, conforme observado em diferentes compostos [17]. 


\section{OBJETIVOS}

\subsection{GERAL}

O presente trabalho visa ao desenvolvimento de forma farmacêutica membrana nanoestruturada de hidrogel para veiculação de complexo de papaína e ciclodextrina - para o tratamento de úlceras dérmicas e feridas.

\subsection{ESPECÍFICOS}

- Avaliação in silico das implicações estruturais da papaína na formação do complexo;

- Síntese e caracterização de complexo de papaína e ciclodextrina;

- Síntese e caracterização do hidrogel contendo o complexo de papaína e ciclodextrina;

- Nanoestruturacão do hidrogel para promover reticulação adequada do hidrogel contendo papaína;

- Avaliação da incorporação e liberação do complexo no hidrogel obtido;

- Avaliação da estabilidade da atividade biológica, perfil citotóxico, avaliação do potencial antimicrobiano e potencial alergênico da forma farmacêutica. 


\section{CONSIDERAÇÕES GERAIS}

\subsection{PAPAÍNA}

A papaína é uma enzima extraída e isolada do látex das folhas e do fruto verde do mamão papaia adulto, Carica papaya Linné [26]. Esta protease é constituída de uma cadeia polipeptídica composta de 212 resíduos de aminoácidos (FIGURA 1) que se dobra para formar dois domínios, L e R. Sua forma é elipsoidal, com dimensões aproximadas de 5,0 × 3,7 x 3,7 nm e apresenta massa molecular de 23.350 Daltons [8].

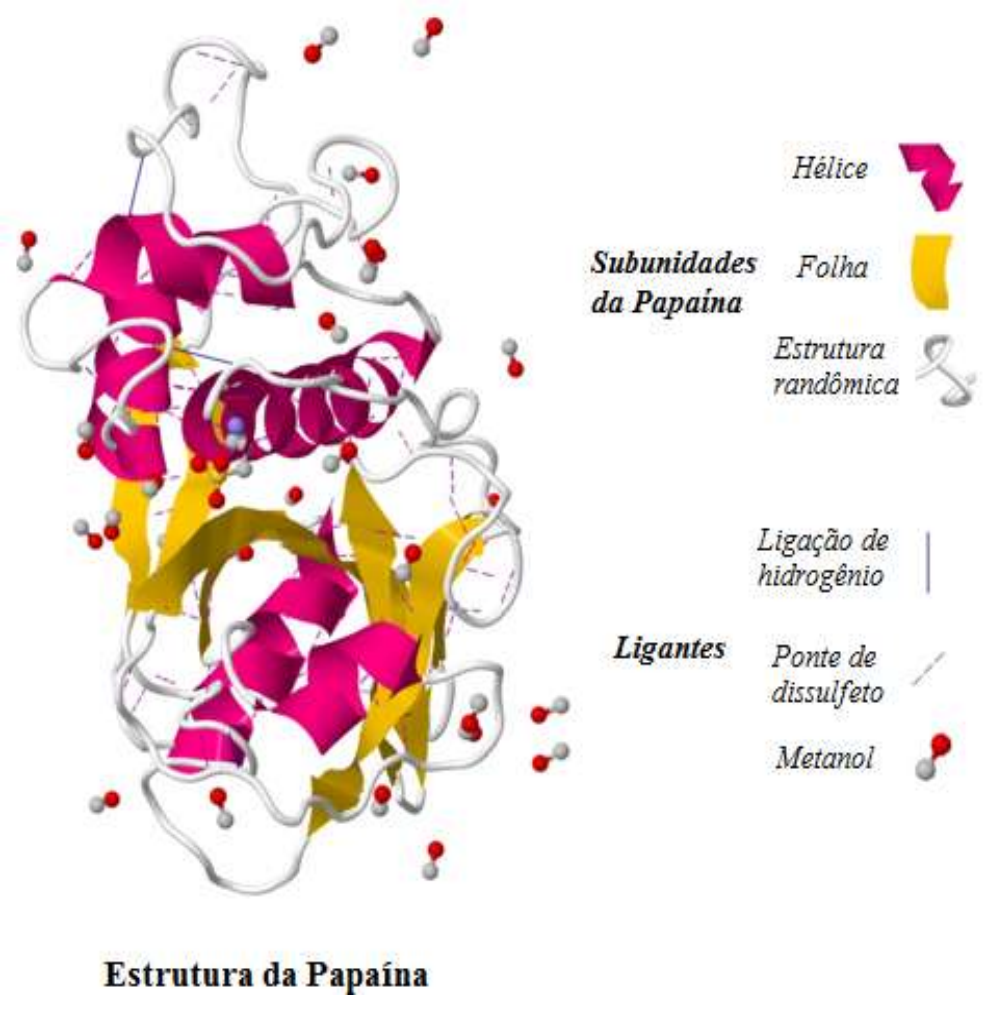

FIGURA 1 - Representação gráfica da molécula da papaína e suas interações intramoleculares (9pap.pdb).

Entre os domínios forma-se um profundo vale, onde se encontra o sítio ativo da enzima, composto pelos resíduos cisteína (Cys-25), histidina (His-159) e ácido 
aspártico (Asp-158). O resíduo Cys-25 possui o grupo sulfidrila essencial, que permanece livre na enzima ativa, enquanto outros seis resíduos de cisteína formam entre si pontes de dissulfeto que estabilizam a estrutura terciária da proteína $[8,27]$.

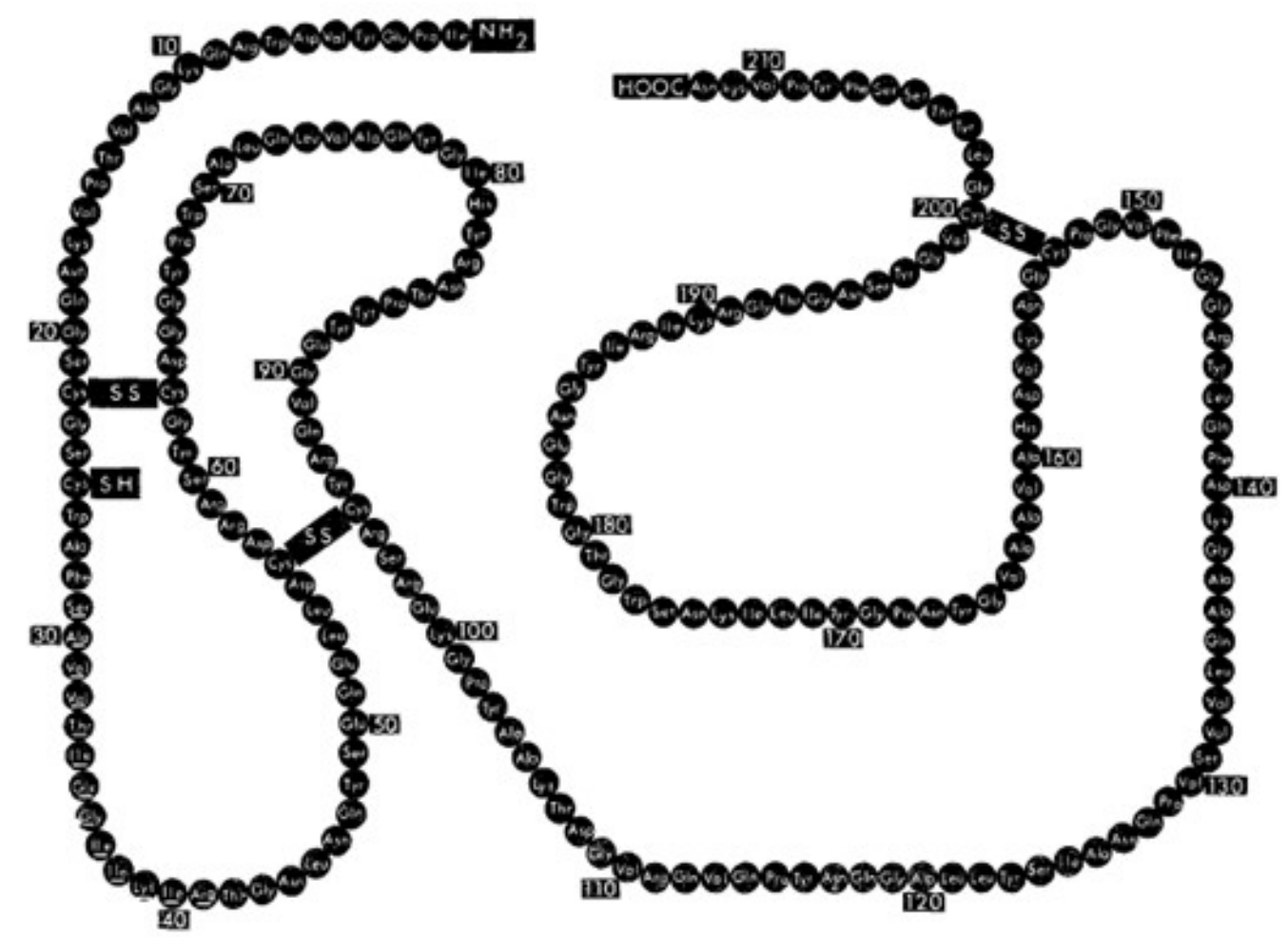

FIGURA 2 - Sequência de aminoácidos presentes na estrutura da papaína. Adaptado de [28].

A distribuição dos aminoácidos (FIGURA 2) ocorre de modo que os resíduos 10-11 e 207-212 estão localizados no domínio I, enquanto os resíduos 1-9 e 12-206 compõem o domínio $R$ [27], conferindo uma estrutura tridimensional composta por subestruturas conhecidas como alfa-hélices, folhas $\beta$-pregueadas, voltas $\beta$ etc $[8,28]$. O resíduo Cys-25 da papaína é posicionado no início da alfa-hélice no domínio $L$ (resíduos 24-42).

Com relação à polaridade dos resíduos presentes na molécula de papaína, sua distribuição e ocorrência está representada graficamente na FIGURA 3. A papaína apresenta grande quantidade de resíduos apolares e polares. 
A

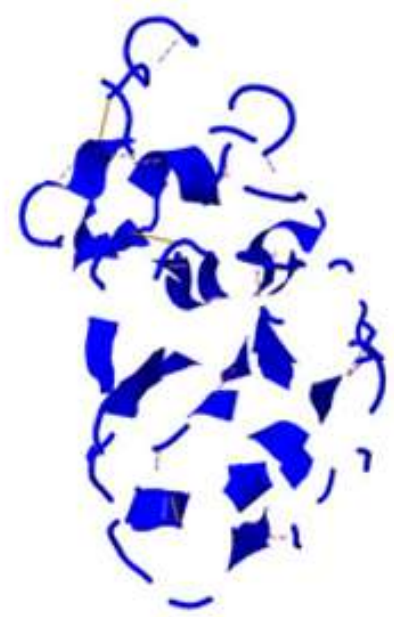

Distribuição dos Resíduos Polares

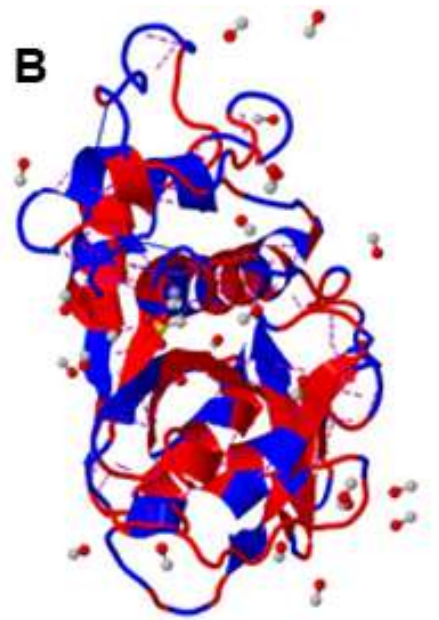

Distribuição de Polaridade

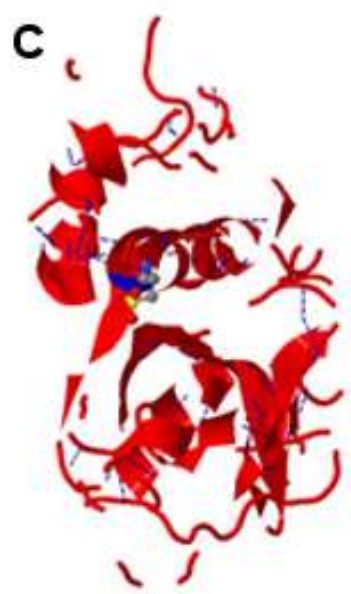

Distribuição dos Residuos Apolares

FIGURA 3 - Distribuição dos aminoácidos presentes na molécula de papaína, de acordo com a polaridade (9pap.pdb), considerando que: $\mathbf{A}$ - resíduos polares (azul); B - todos os resíduos; C - resíduos apolares (em vermelho);

A enzima apresenta ponto isoelétrico teórico de 8,88 [8], e a distribuição das diferentes cargas de cada resíduo que compõem a molécula da papaína está representada na FIGURA 4.

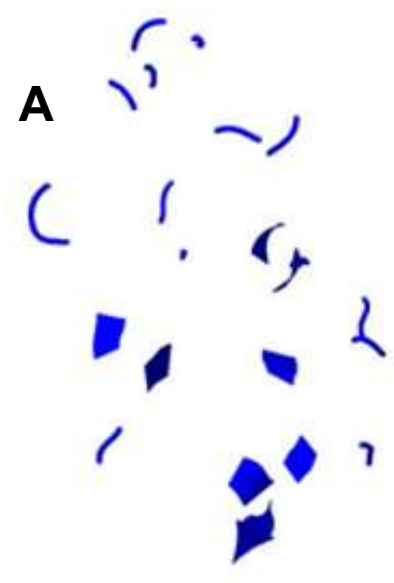

Distribuição de Aminoácidos Básicos

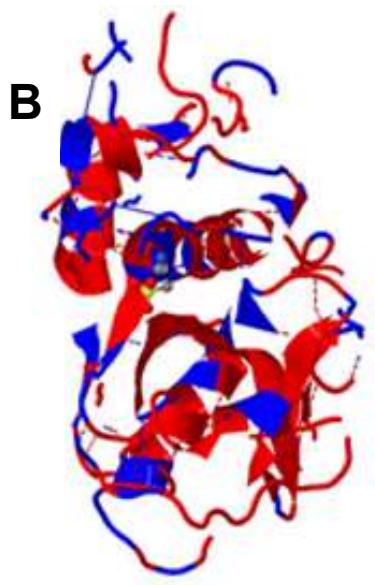

Distribuição de Aminácidos Neutros

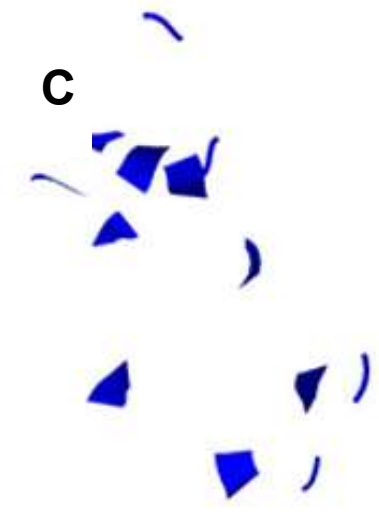

Distribuição de Aminoácidos Ácidos

FIGURA 4 - Distribuição dos aminoácidos presentes na molécula de papaína, de acordo com a carga (9pap.pdb), considerando que: A - resíduos básicos; B resíduos neutros (vermelho - apolares; azul - polares); C - resíduos ácidos. 
A papaína apresenta ampla faixa de estabilidade com relação ao $\mathrm{pH}$, variando entre 3-9, com pH ótimo de 6-7 [29] e estabilidade térmica, com temperatura ótima de $65^{\circ} \mathrm{C}[30]$ e solubilidade em água $10 \mathrm{mg} \cdot \mathrm{mL}^{-1}[31]$.

\subsubsection{ATIVIDADE BIOLÓGICA}

A papaína apresenta ampla atividade enzimática, considerando ação como endopeptidase, amidase e estearase [32]. A especificidade da papaína em geral é controlada pelo subsítio $S_{2}$, exercendo a função de acomodar a cadeia lateral do substrato $\left(P_{2}\right)$. Além deste, outros seis subsítios ( $S 1$, $S 3$ e $S 4$; $S 1^{\prime}$ - $\left.S 3^{\prime}\right)$, também acomodam um resíduo do substrato $\left(\mathrm{P}_{1}-\mathrm{P}_{4} ; \mathrm{P}_{1}{ }^{\prime}-\mathrm{P}_{3}{ }^{\prime}\right)$ em sua cavidade [33].

De maneira mais específica, a papaína cliva ligações peptídicas de aminoácidos básicos, como leucina ou glicina. Existe uma restrição para o resíduo valina na posição $P_{1}$ [34] e a enzima é capaz de hidrolisar ésteres e amidas [32]. $O$ esquema representativo da interação específica da papaína com substratos proteicos está descrito na FIGURA 5.

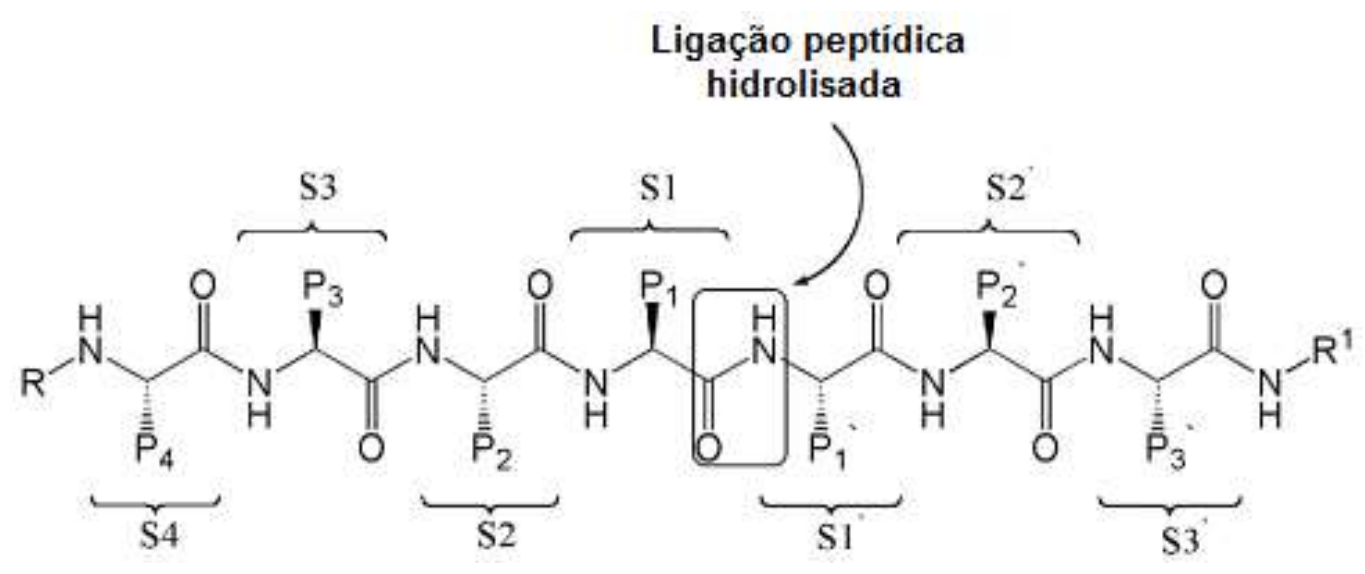

FIGURA 5 - Interação específica da papaína com substrato. Adaptado de [35]. 


\subsubsection{APLICAÇÕES FARMACÊUTICAS E BIOTECNOLÓGICAS}

As aplicações farmacêuticas e biotecnológicas da papaína são amplas, tanto em nível industrial (devido à sua estabilidade térmica e especificidade) quanto laboratorial ou ambulatorial. Dentre elas, destacam-se o isolamento de células como neurônios, retina e musculatura lisa, debridamento proteolítico (incluindo tratamento de escaras e queimaduras), fragmentação de anticorpos e peptídeos, clarificação de cerveja, mapeamento de proteínas e peptídeos, remoção de cáries, dentre outros [4, 32]. A TABELA 1 contém as principais aplicações industriais da papaína atualmente.

TABELA 1 - Resumo das principais aplicações industriais da papaína e outras cisteíno-proteases.

\begin{tabular}{|c|c|}
\hline Setor Industrial & Uso/Aplicação \\
\hline Detergente & Remoção de proteínas. \\
\hline \multicolumn{2}{|l|}{ biológico } \\
\hline Fermentações & $\begin{array}{l}\text { Remoção e separação de proteínas em cervejas e outros } \\
\text { produtos. }\end{array}$ \\
\hline Laticínios & Hidrólise do trigo; cura de queijo e derivados. \\
\hline Alimentícia & $\begin{array}{l}\text { Amaciante de carnes; estabilização de gelatinas; cura de } \\
\text { produtos. }\end{array}$ \\
\hline Trat. de efluentes & $\begin{array}{l}\text { Redução da viscosidade de extratos aquosos; quebra de } \\
\text { proteínas. }\end{array}$ \\
\hline Cosmética & $\begin{array}{l}\text { Promotor de absorção; peeling cutâneo; clareamento de } \\
\text { dentes. }\end{array}$ \\
\hline Farmacêutica & Limpeza de lentes; agente debridante; auxiliar na digestão; \\
\hline Têxtil & $\begin{array}{l}\text { Processamento de lãs; refinamento de seda; tratamento de } \\
\text { couros. }\end{array}$ \\
\hline Nutrição animal & Aumento da disponibilidade e inversão de proteínas. \\
\hline Indústria química & $\begin{array}{l}\text { Síntese de peptídeos e agentes antitumorais; fragmentação } \\
\text { de anticorpos. }\end{array}$ \\
\hline
\end{tabular}

${ }^{\star}$ Adaptado de [35]. 
A fragmentação de anticorpos é uma aplicação importante da papaína, conforme detalhado por diversos autores [36, 37], uma vez que esta, de maneira distinta de outras proteases, permite a separação em dois fragmentos Fab monovalentes e um fragmento de FC (FIGURA 6). Fatores como elevada estabilidade em ampla faixa de $\mathrm{pH}$, dentre outras propriedades da papaína, também contribuem para o uso em larga escala desta biomolécula.

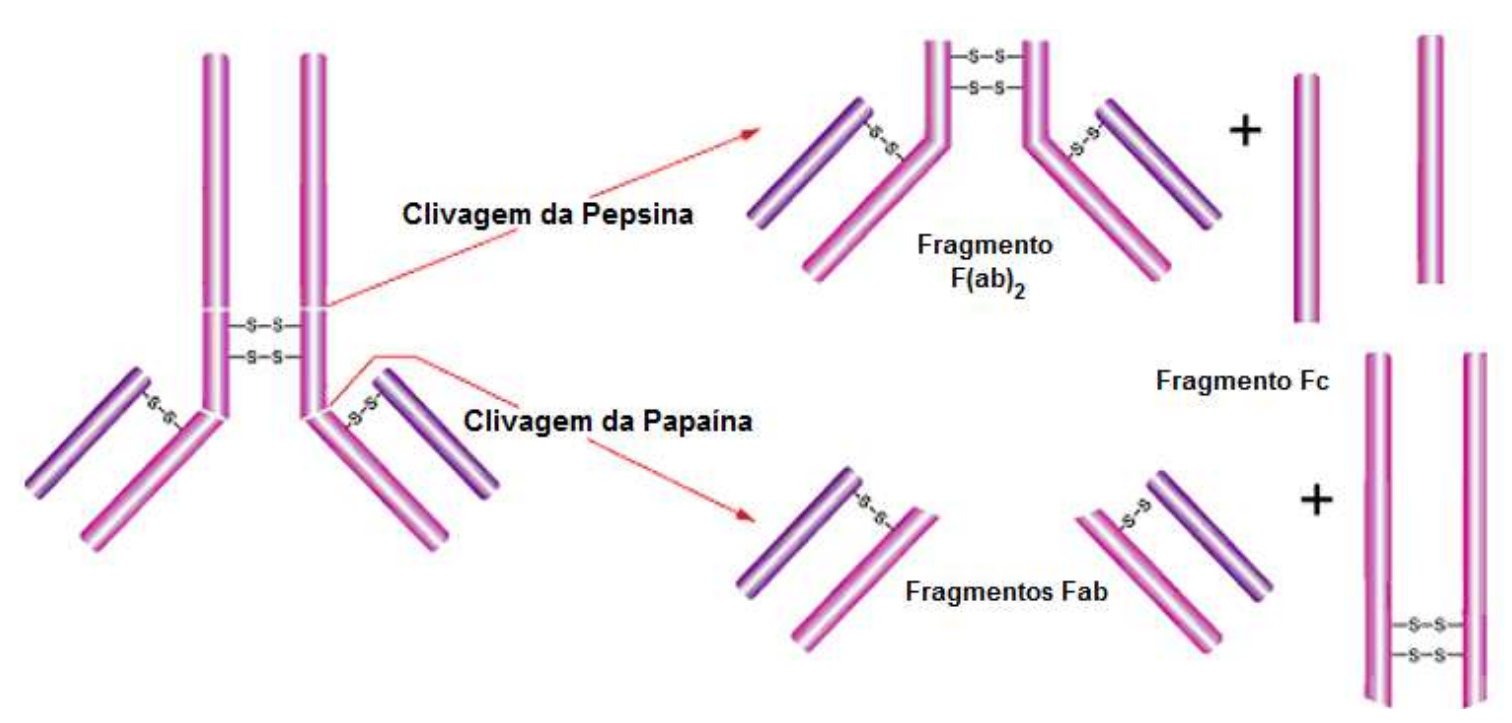

FIGURA 6 - Seletividade e diferença da clivagem de anticorpos utilizando a papaína e a pepsina. Adaptado de [38].

O isolamento de células corresponde a uma das aplicações mais conhecidas da papaína, considerando que, de maneira distinta em relação as outras proteases ou métodos, o referido processo na presença dessa enzima é desencadeado de modo a permitir um isolamento gradual e lento das células, acarretando maior rendimento e menor dano às células isoladas. Em especial, destaca-se o isolamento de células neuronais [39].

A seguir, (FIGURA 7) apresenta-se papaína disponível comercialmente para isolamento de células de tecido neuronal. 


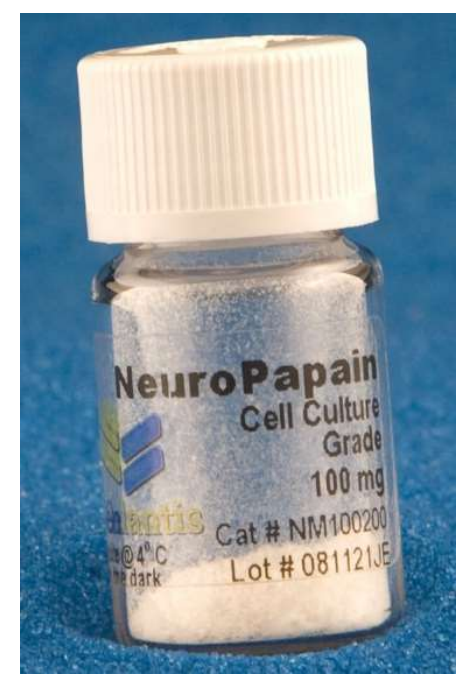

FIGURA 7 - Papaína de uso comercial (NeuroPapain ${ }^{\top \mathrm{M}}$ - Gelantis) específica para dissociação de células de tecido neuronal. Disponível em [40].

Segundo dados do fabricante, a formulação assegura uma dissociação facilitada e com altos índices de viabilidade celular. O produto apresenta estabilidade por seis meses sob armazenamento na forma sólida e temperaturas não superiores a $4{ }^{\circ} \mathrm{C}$.

$\mathrm{Na}$ FIGURA 8 observa-se uma solução padronizada de papaína, comercialmente conhecida como ID-Papain ${ }^{\circledR}$, destinada ao pré-tratamento de células vermelhas, ou emprego como aditivo no isolamento de células. A solução apresenta estabilidade por 7 semanas.

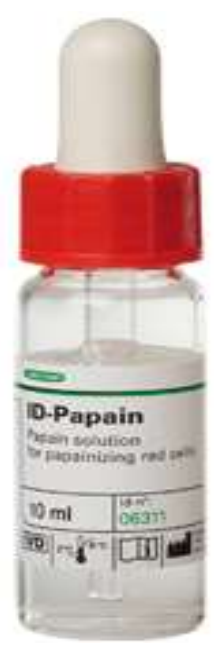

FIGURA 8 - Solução Padronizada de papaína (ID-Papain ${ }^{\circledR}$ ). Disponível em [41]. 


\subsubsection{MEDICAMENTOS CONTENDO PAPAÍNA}

Anteriormente à restrição imposta pela FDA [7], diversos produtos tópicos contendo papaína para uso humano estavam disponíveis no mercado. Produtos estes comumente associados a outros agentes, como a ureia, a clorofila, e alguns metais, com a finalidade de facilitar a ação da enzima, além de melhorar os efeitos destes agentes sobre a ferida em alguns casos [2].

Pomadas (FIGURA 9) e emulsões (FIGURA 10) consistiam, e talvez ainda sejam, as formas farmacêuticas de escolha para a veiculação da papaína, dado o baixo teor de água, favorecendo, assim, a manutenção da estabilidade da enzima.

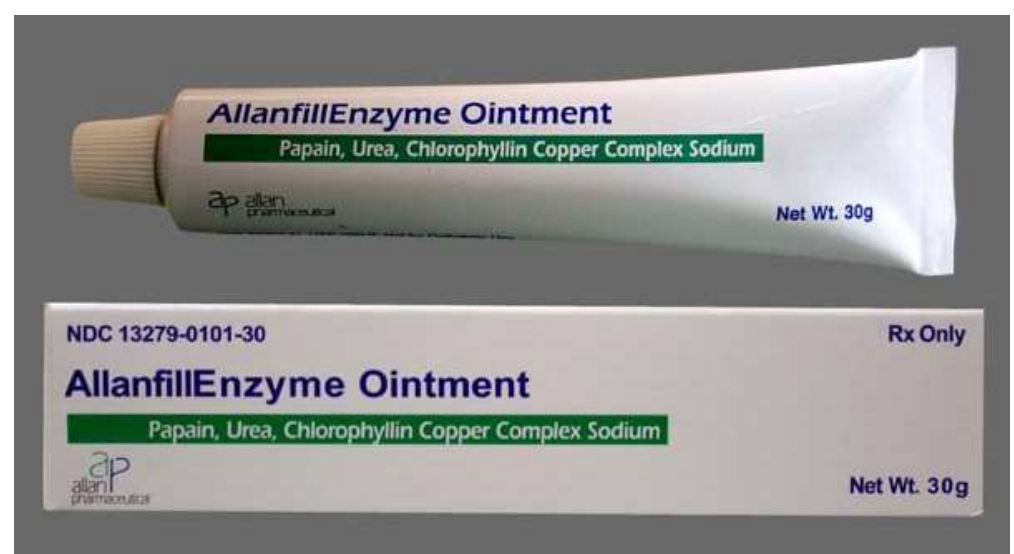

FIGURA 9 - Pomada contendo papaína, uréia e clorofila (Allanfill ${ }^{\circledR}$ ). Disponível em [42].

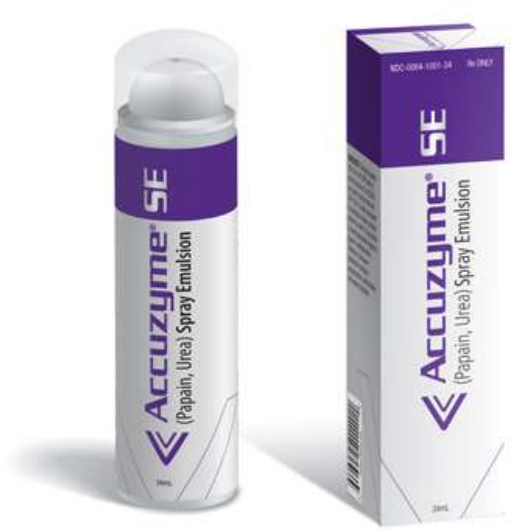

FIGURA 10 - Emulsão em spray contendo papaína e uréia $\left(\right.$ Accuzyme $^{\circledR}$ )SE. Disponível em [43]. 
No Brasil, atualmente a papaína é veiculada em géis que frequentemente apresentam baixa estabilidade, com prazo de validade estimado de 60 dias, e na forma extemporânea, sendo preparada solução para debridamento em condições assépticas.

No caso dos produtos para uso tópico, a aplicação da papaína foi restrita [4]. Suplementos alimentares que auxiliam na digestão e que contêm papaína em sua formulação (FIGURA 11) ainda são comercializados e, neste caso, não estão sujeitos à restrição. Muitas vezes, a formulação desses produtos contém papaína associada à bromelina [44].

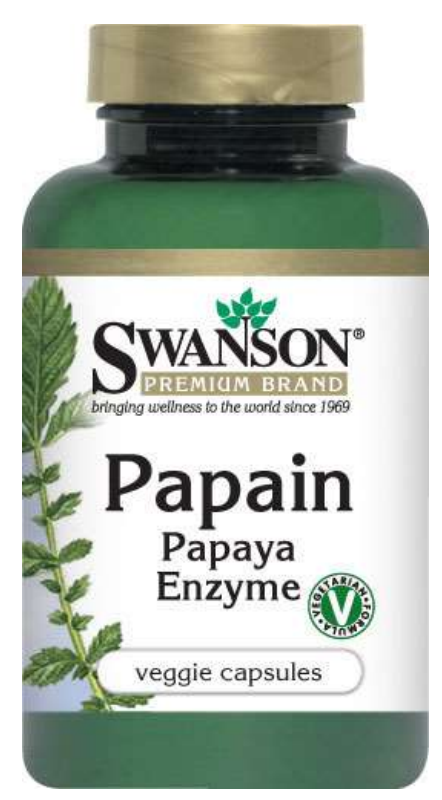

FIGURA 11 - Suplementos contendo papaína como auxiliar na digestão. Disponível em [45].

A forma sólida contendo papaína apresenta vantagens quando comparada a outras formas farmacêuticas, devido ao baixo teor de água e à pequena quantidade de processos necessários para obtenção do sistema [46]. 


\subsubsection{SISTEMAS DE ESTABILIZAÇÃO DA PAPAÍNA}

Como característica das cisteíno-proteases, a papaína possui uma cisteína no sítio ativo (Cis-25), e a oxidação deste resíduo é o principal mecanismo responsável pela inativação da enzima em soluções aquosas $[8,28]$. Adicionalmente a este fenômeno, a papaína apresenta um mecanismo natural de abertura que acarreta perda de atividade enzimática em soluções aquosas [8]. Do ponto de vista prático, o decréscimo da atividade enzimática em soluções aquosas ocorre na faixa de 1-2 \% ao dia [26].

Considerando estas premissas, a formulação e o desenvolvimento de medicamentos e formas farmacêuticas para veiculação da papaína correspondem a uma tarefa árdua e desafiadora, com relação à manutenção da estabilidade da atividade enzimática em função do tempo.

Atualmente, algumas técnicas avançadas são empregadas para estabilização da papaína, como a imobilização em suportes metálicos [47], nanocompósitos de ouro magnético [48], ou o aprisionamento em matrizes poliméricas [49,50] em tecidos à base de algodão [51], dentre outras. Na FIGURA 12 observa-se papaína imobilizada em resina de agarose, comercialmente disponível, utilizada para fragmentação de anticorpos.

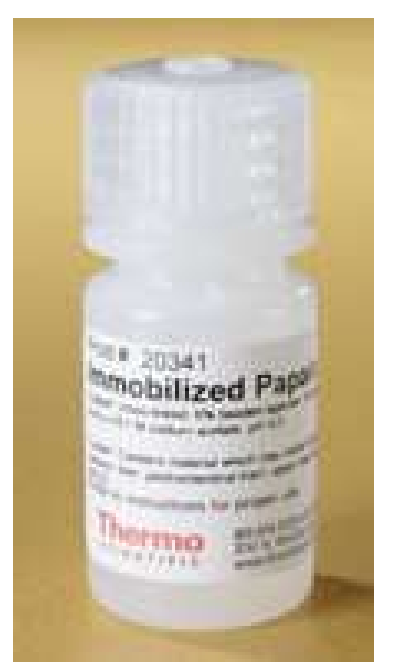

FIGURA 12 - Papaína imobilizada em agarose comercialmente disponível (immobilized Papain - Thermo Scientific Pierce). Disponível em [52]. 
É relevante destacar que, além de problemas atribuídos às reações adversas graves de origem imunológica, o problema de estabilidade biológica da papaína ainda permanece sem solução, mesmo nas formas mais avançadas de administração disponíveis.

\subsection{TECNOLOGIA DAS CICLODEXTRINAS}

As CDs são oligossacarídeos cíclicos formados por moléculas de D-glicose, unidas através de ligações $\alpha$ (1-4). De acordo com o número de unidades de glicose podemos classificar as ciclodextrinas (FIGURA 13) como $\alpha$-CD (6 glicoses), $\beta$-CD ( 7 glicoses) e $\gamma$-CD (8 glicoses) [53].

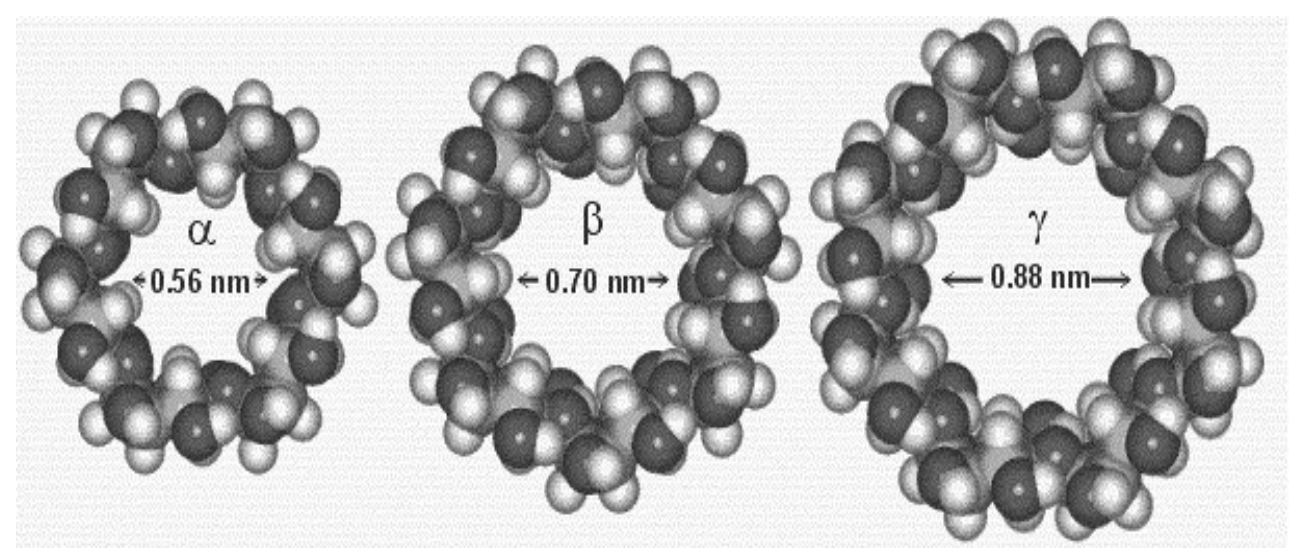

FIGURA 13 - Representação gráfica da estrutura das ciclodextrinas naturais. Adaptado de [54].

Em solução aquosa, as cavidades das CDs proporcionam uma região hidrofóbica em um ambiente hidrofílico, conferindo à molécula a habilidade de formar complexos de inclusão com diferentes moléculas, limitadas, dentre outros fatores, por restrições estéricas de sua cavidade interna. Tal propriedade justifica seu amplo uso industrial nas áreas farmacêutica, cosmética, alimentícia e agrícola [55]. A estrutura da molécula de ciclodextrina pode ser visualizada na FIGURA 14. 

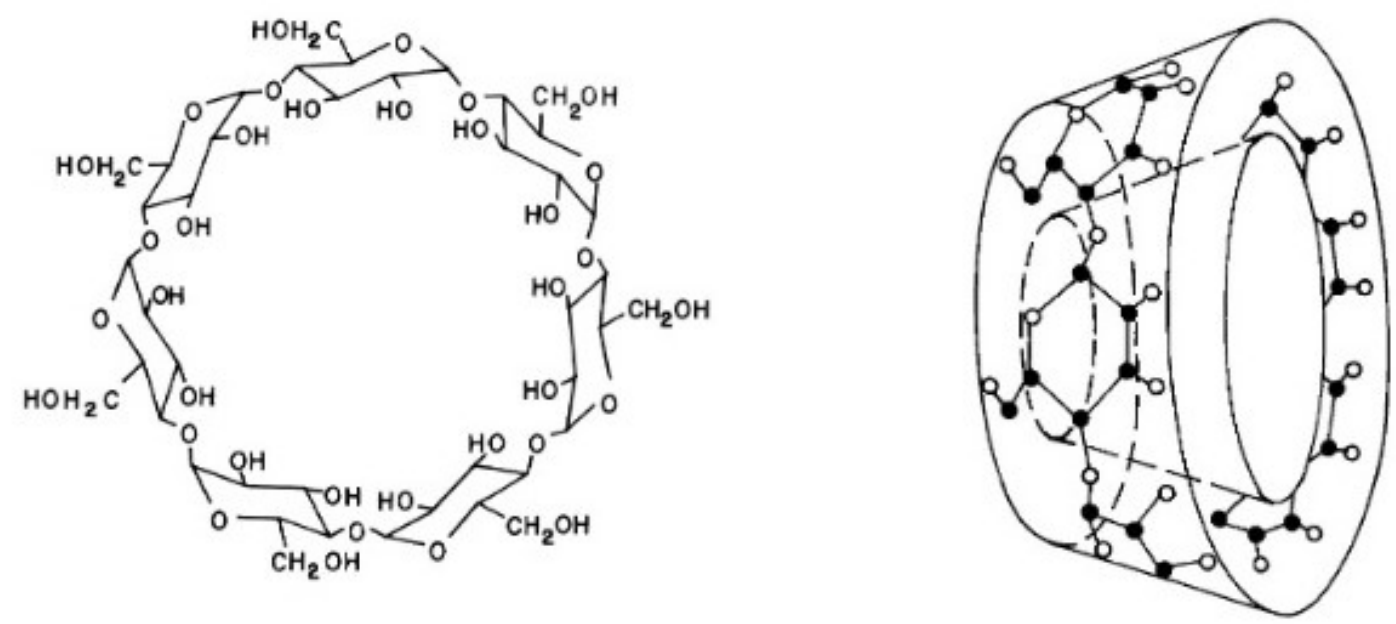

FIGURA 14 - Esquema representativo da molécula de ciclodextrina. Adaptado de [53].

O avanço da tecnologia em síntese molecular permitiu a elaboração de ciclodextrinas com propriedades melhoradas por meio da adição ou substituição de um radical na molécula, denominadas ciclodextrinas modificadas. Dentre tais propriedades, maior solubilidade em meios aquosos e melhor capacidade de formação de complexos de inclusão correspondem aos principais efeitos de tais modificações. Exemplos de radicais adicionados à estrutura da molécula podem ser visualizados na FIGURA 15.
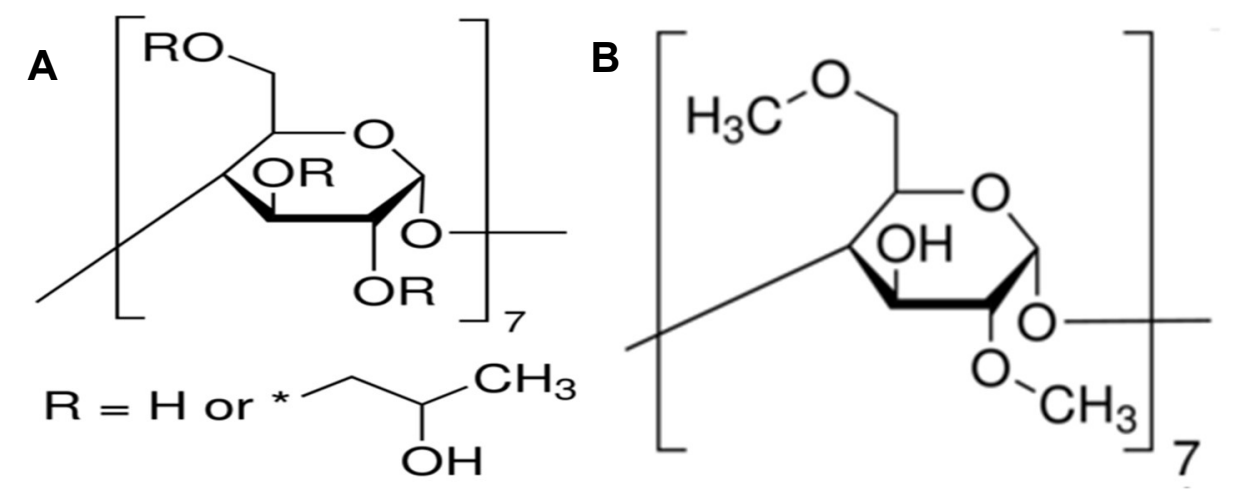

FIGURA 15 - Exemplos de modificações realizadas nas $\beta$-ciclodextrinas, considerando que: A - Radical hidroxipropil; B - Radical dimetil. 


\subsubsection{COMPLEXOS ENTRE CICLODEXTRINAS E PROTEÍNAS}

As CDs apresentam a capacidade de formar complexos com moléculas proteicas, por meio da formação de complexos de inclusão entre sua cavidade hidrofóbica interna e alguns aminoácidos específicos, o que leva a modificações nas propriedades da substância complexada $[22,24,56,57]$.

A seleção de $\beta$-ciclodextrina ao invés de $\alpha$ ou $\gamma-C D$ para a formação do complexo é devida à possibilidade de acomodação de moléculas biológicas no interior de sua cavidade com maior eficácia, além do custo inferior e obtenção mais simples [22,56]. A formação de complexos com proteínas pode ser observada na FIGURA 16.

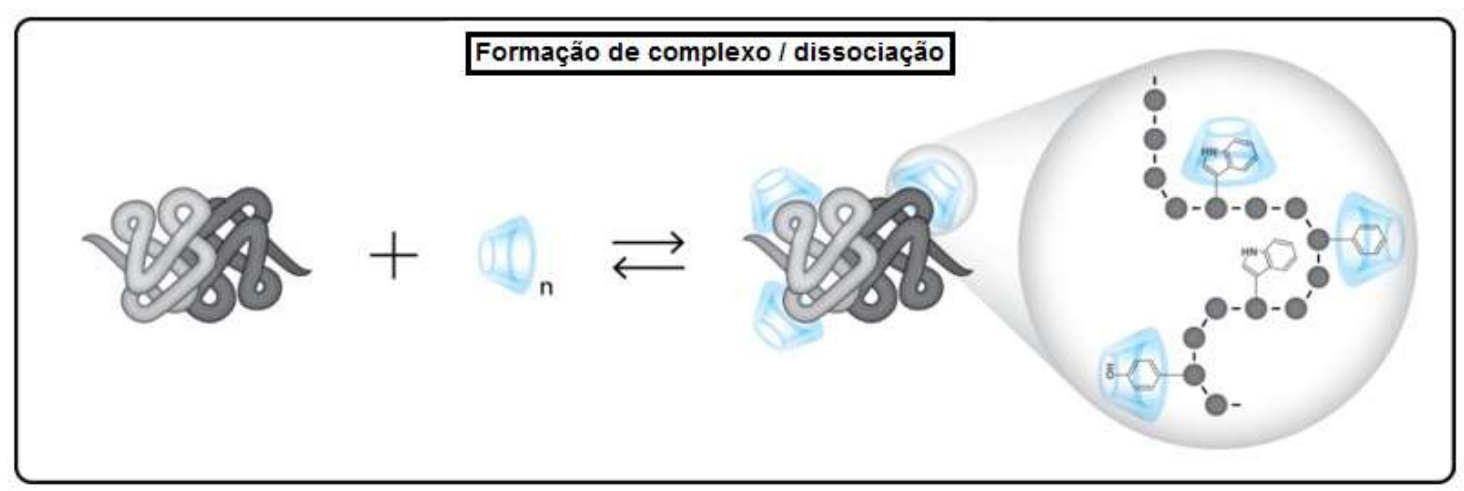

FIGURA 16 - Esquema representativo da formação de complexos entre proteínas globulares e ciclodextrinas.

A interação da ciclodextrina com proteínas ocorre através da formação de complexos de inclusão com alguns resíduos de aminoácidos específicos presentes na estrutura proteica, envolvendo os grupamentos aromáticos presentes na cadeia lateral de alguns aminoácidos, como os resíduos de fenilalanina, triptofano e tirosina [56,57,58]. Os aminoácidos passíveis de complexação com a ciclodextrina podem ser observados na FIGURA 17. 


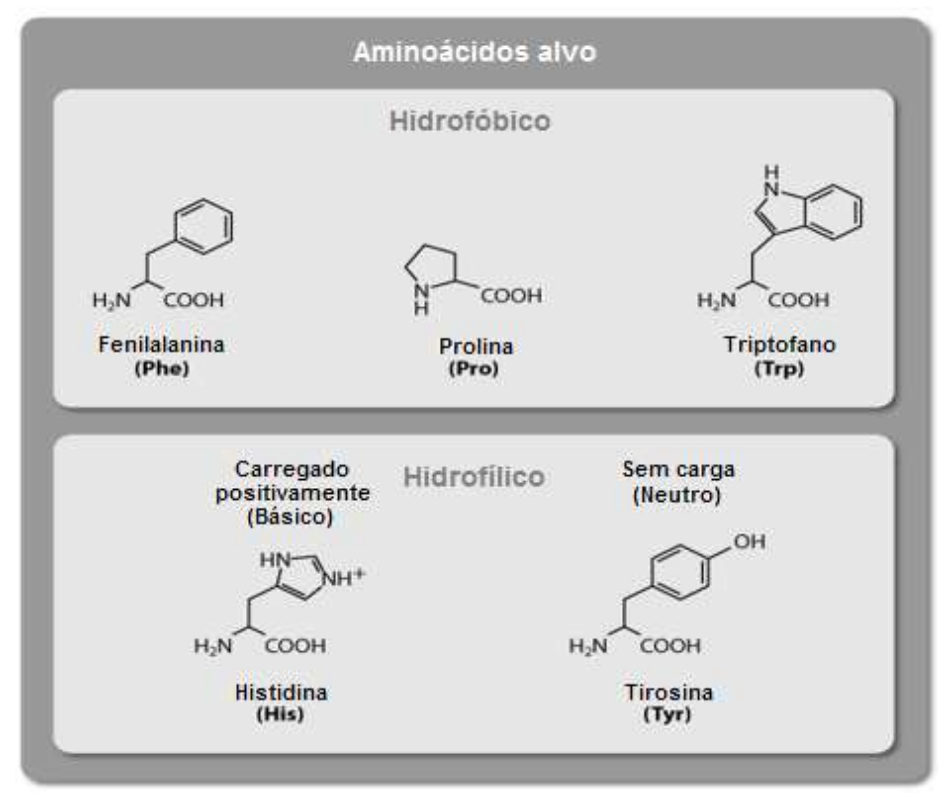

FIGURA 17 - Aminoácidos-alvo do encapsulamento molecular das ciclodextrinas em proteínas globulares e peptídeos.

A formação de complexo também pode ocorrer com resíduos de histidina e prolina. Contudo, em se tratando de ciclodextrinas naturais ( $\alpha, \beta$ e $\gamma-C D)$, as mesmas tendem a apresentar uma força de ligação muito baixa, graças à pouca afinidade entre as estruturas apresentadas (FIGURA 18 A e B), dentre outros aspectos, e à presença de cargas (histidina) ou efeitos estéricos (prolina) $[56,57,58]$.
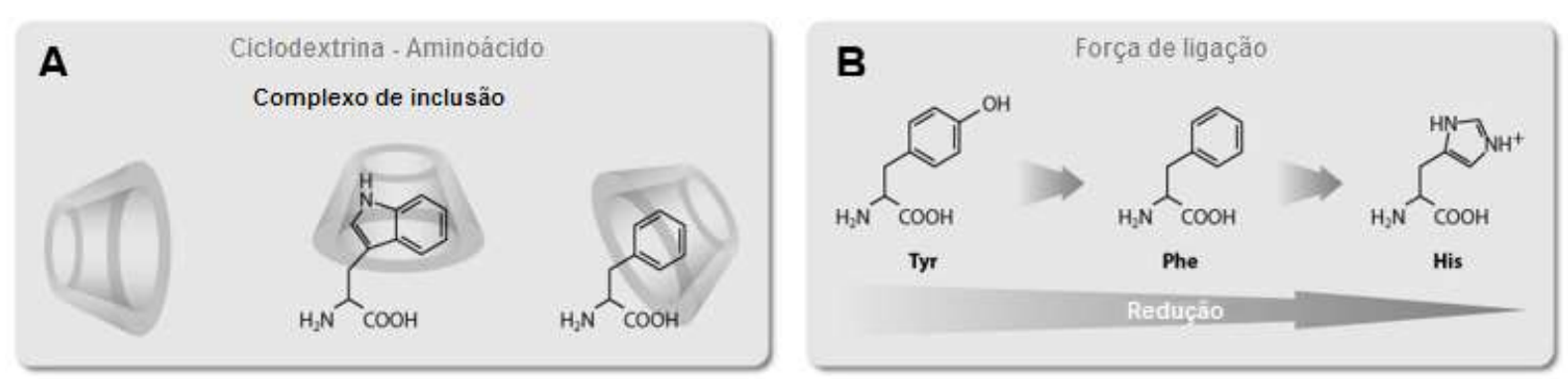

FIGURA 18 - Interação entre ciclodextrinas e aminoácidos, considerando que: A formação dos complexos de inclusão molecular entre aminoácidos e ciclodextrinas; B - força de ligação entre ciclodextrina e os aminoácidos-alvo. 
O emprego de ciclodextrinas para formação do complexo com proteínas é conhecido por auxiliar na renaturação proteica (protein folding agents) e promover melhora na estabilidade térmica e biológica, entre outros [56,58].

Estudos anteriores forneceram indícios da formação de complexo entre papaína e ciclodextrina, resultando em melhora na citotoxicidade e na estabilidade térmica da enzima [25]. No entanto, não existem evidências concretas de que as melhorias ocorreram em função da formação do complexo, ou apenas em função da presença do oligossacarídeo. Além da importância de caracterização adequada da formação do complexo de papaína e ciclodextrina, se faz necessária uma avaliação da citocompatibilidade do ativo desenvolvido, bem como da influência da ciclodextrina nas propriedades imunogênicas da papaína, uma vez que tais propriedades podem ser alteradas em função da complexação.

\subsection{PROCESSAMENTO POR RADIAÇÃO}

A irradiação por altas energias é um processo amplamente utilizado internacionalmente, com aplicações na agricultura, biomedicina, alimentos e outras áreas relacionadas. Dentre as principais aplicações, estão a esterilização de dispositivos biomédicos e o desenvolvimento de materiais avançados. Do ponto de vista nanotecnológico, a irradiação consiste em técnica promissora para o desenvolvimento de materiais nanoestruturados $[59,60]$.

O efeito da radiação sobre as moléculas induz à quebra das ligações moleculares, levando à formação de radicais livres [61], como o radical superóxido [62,63], (subproduto da radiólise da água) (FIGURA 19). Esses radicais são capazes de induzir a degradação enzimática [64]. Há também os intermediários formados, $\mathrm{OH}^{*}$ e e`aq, que são responsáveis pela maioria dos efeitos causados às biomoléculas. 
RADIÓLISE DA ÁGUA

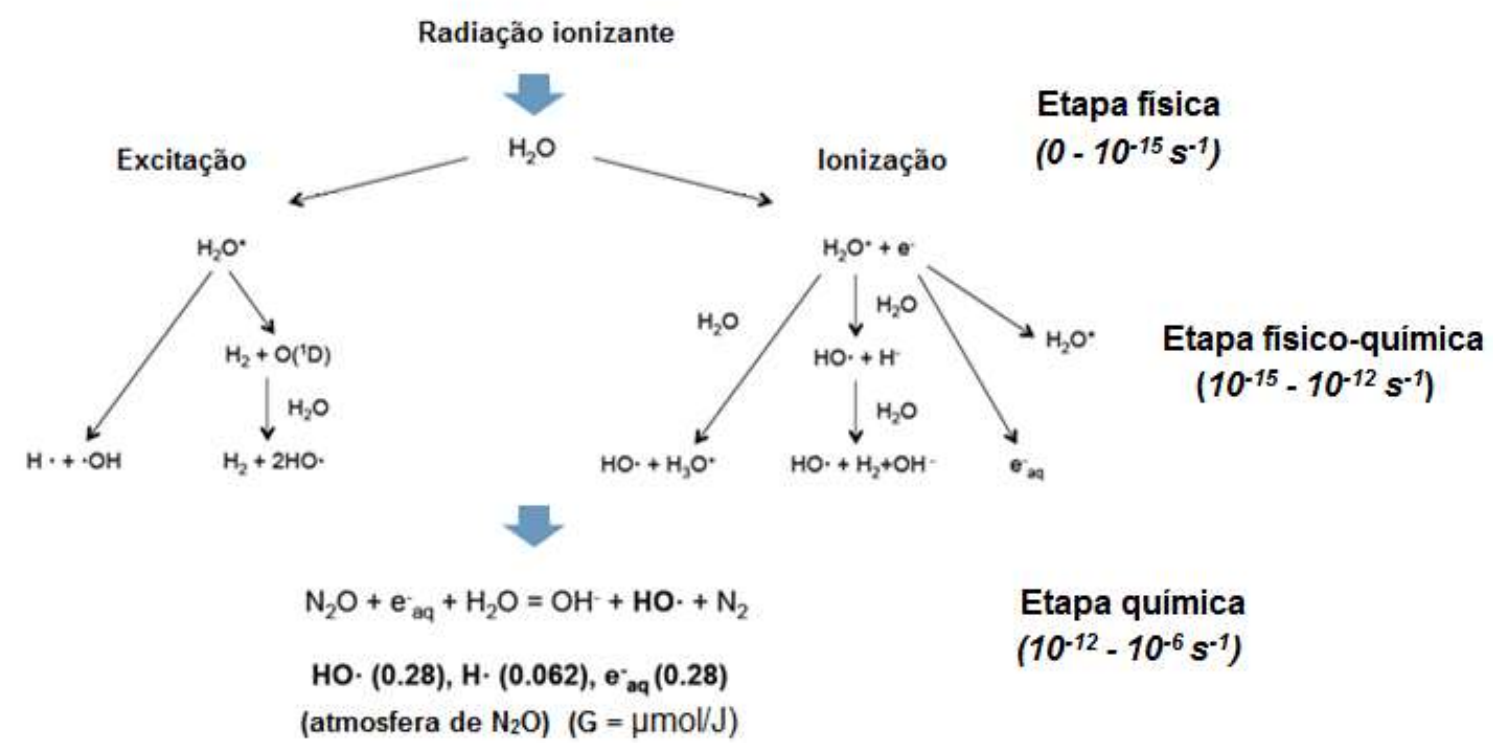

FIGURA 19 - Esquema representativo da radiólise da água. Adaptado de [65].

Os efeitos destes radicais sobre estruturas proteicas podem levar a alterações na cadeia lateral dos aminoácidos, comprometendo a integridade dos resíduos atingidos e, desta forma, comprometendo a estrutura secundária, terciária e quaternária da enzima; causando, consequentemente, alterações na conformação da proteína, e na estabilidade destas biomoléculas [66]. Tais efeitos, contudo, dependem da dose e da fonte de radiação utilizadas, das condições de irradiação, do meio e seus componentes e da proteína propriamente dita.

A exposição à radiação gama consiste em técnica importante para a resolução do problema de imunogenicidade da papaína, uma vez que o processo pode alterar o perfil imunogênico de compostos proteicos [17] por meio de alterações na estrutura de proteínas, além de causar a destruição de patógenos e microrganismos deteriorantes [18] e, desta forma, promover esterilização.

De maneira mais específica, os principais efeitos causados pela radiação são divididos em dois tipos: os efeitos diretos resultantes da transferência direta de energia [67], conforme supracitado, e os efeitos indiretos, relacionados às espécies reativas produzidas. 
Em meios aquosos, os efeitos indiretos são mais pronunciados, enquanto, na forma sólida, os efeitos causados são resultantes da transferência direta de energia. Com relação à radiólise da água, as espécies mais reativas correspondem à radical hidroxila $\left(\mathrm{OH}^{\circ}\right)$ e o elétron aquoso $e^{-}{ }^{-}$[67].

A interação entre os radicais oriundos da radiólise da água com as estruturas proteicas pode ser definida pela EQUAÇÃO 1 A e B, onde k representa a constante da reação.

$$
\text { papaína }+\mathrm{OH}_{\boldsymbol{k}}^{\rightarrow} \underset{\text { papaína }}{ }+\mathrm{H}_{2} \mathrm{O}
$$

$$
\text { papaína }+e_{a q}^{-} \underset{k}{\rightarrow} \text { papaína }^{-}
$$

Os alvos principais destes radicais correspondem à histidina, tirosina, triptofano, metionina e cisteína, acarretando degradação proteica e perda considerável de atividade enzimática [68]. A determinação destes parâmetros é fundamental para se entender a interação da radiação com a molécula em estudo.

\subsection{HIDROGÉIS}

Hidrogéis são sistemas poliméricos reticulados que apresentam a capacidade de reter água dentro da malha tridimensional formada. Tais reticulações ou entrecruzamentos correspondem à porção insolúvel, denominada gel [19].

Atualmente, os hidrogéis são empregados como curativos por serem não tóxicos, hipoalergênicos, e permitirem a redução do trauma durante a troca de curativos [69]. Na FIGURA 20 destacam-se hidrogéis comercialmente disponíveis à base de polivinilpirrolidona para aplicação como curativos dérmicos. 

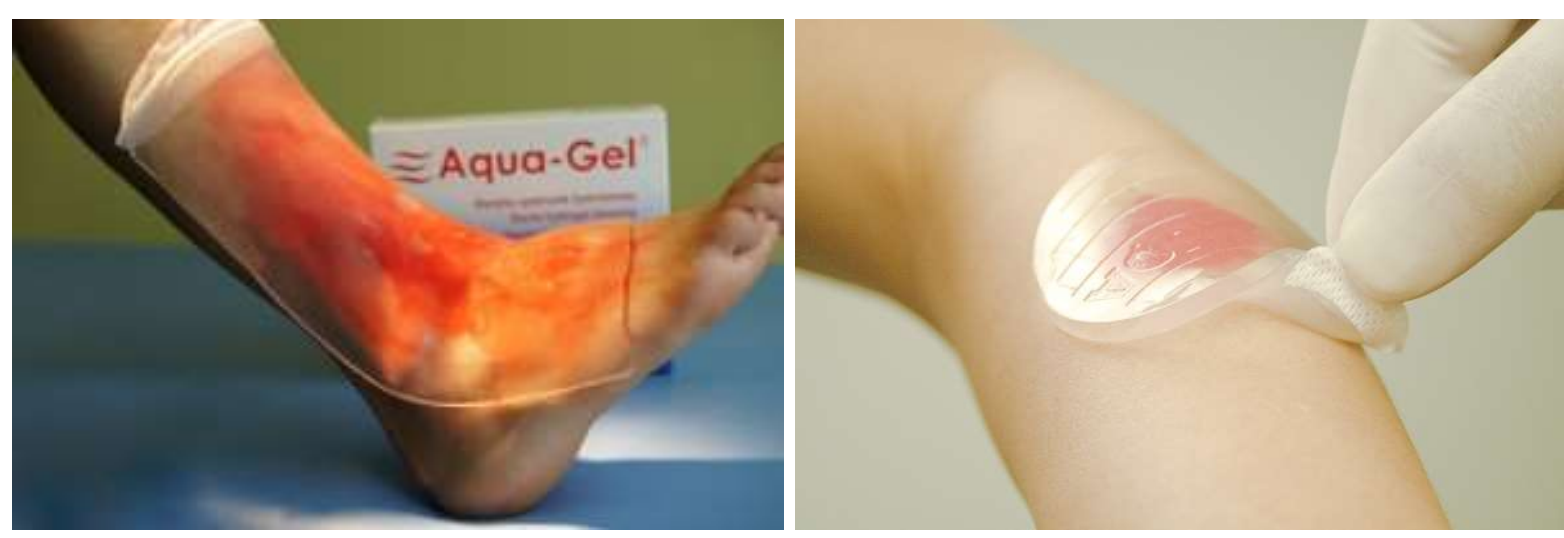

FIGURA 20 - Hidrogéis à base de PVP comercialmente disponíveis produzidos por radiação (Aqua-Gel ${ }^{\circledR}$ da KikGel) [70].

Tais materiais também são alvos de estudos relacionados à veiculação de drogas, sendo amplamente utilizados como carreadores de ativos, principalmente por promover uma cinética de liberação específica, além de permitir a possibilidade de veiculação de uma vasta classe de moléculas e compostos de interesse.

Uma outra aplicação importante dos hidrogéis envolve a produção de lentes de contato (FIGURA 21), as quais podem ainda apresentar ou não fármaco encapsulado [71].

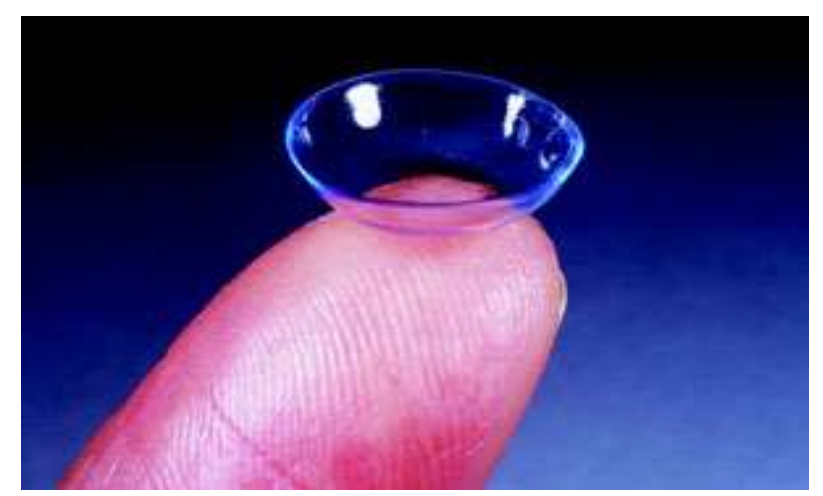

FIGURA 21 - Lente de contato constituída de hidrogel de silicone [72].

O emprego da radiação na formação de hidrogéis possibilita diminuição no número de processos para obtenção do produto final frente às técnicas usuais de produção, promovendo a esterilização do produto, que é essencial para a aplicação 
em feridas e escaras, além da formação simultânea do hidrogel em si, por meio da reticulação das moléculas poliméricas [19,69]. Desta forma, a possível degradação enzimática relacionada ao processamento é minimizada, quando o processamento por radiação é empregado.

\subsubsection{HIDROGÉIS PARA LIBERAÇÃO DE PROTEÍNAS}

O processo de enredamento (ou imobilização por enredamento) consiste no aprisionamento da proteína nos poros da rede do hidrogel, sob a influência de efeitos estéricos, não estando, necessariamente, ligada quimicamente à matriz. Embora processos de imobilização, como por enredamento ou via ligações covalentes, acarretem perda de parte da atividade enzimática decorrente da imobilização, a veiculação de proteínas em hidrogéis é particularmente interessante, umas vez que, embora o sistema possua alta quantidade de água, entre $80-90 \%$, essa água é compreendida entre a matriz polimérica assim como a proteína, conferindo mobilidade restrita a ambas, propiciando maior estabilidade a proteína, mesmo em um ambiente aquoso, frente aos sistemas convencionais.

A literatura dispõe de alguns trabalhos relacionados ao desenvolvimento de hidrogéis para liberação da papaína. Fogaça e colaboradores (2009) desenvolveram hidrogel superabsorvente contendo papaína e prata $\left(\mathrm{Ag}^{+}\right)$para aplicação em feridas crônicas, com atividade biocida e liberação adequada [75]. Embora a forma farmacêutica fosse comprovadamente eficaz, a imunogenicidade e a estabilidade biológica não foram avaliadas.

Acrilatos são exemplos de classe de polímeros adequada para síntese de hidrogéis superabsorventes, capazes de conferir um perfil de liberação adequado da papaína [49]. Outros sistemas poliméricos também foram desenvolvidos para administração da papaína. Zulli (2008) desenvolveu uma matriz polimérica com base de silicone mono e bicomponente para a liberação controlada da papaína. Porém, esta liberação promovida pelas membranas avaliadas foi inadequada, devido aos problemas na nanoestruturação do gel, que conferiu poros de tamanho reduzido que comprometeram a liberação da enzima [50]. 
No entanto, problemas relacionados aos possíveis efeitos imunogênicos da papaína contida nos medicamentos disponíveis comercialmente e em sistemas avançados ainda permanecem não solucionados. Por consequência, a busca por uma forma farmacêutica ou um sistema capaz de promover redução na imunogenicidade da enzima se faz de grande relevância na atualidade.

\subsubsection{NANOESTRUTURAÇÃO}

A formação da rede tridimensional do hidrogel, decorrente da reticulação polimérica é, dependente de vários fatores, como o meio reacional, influenciada pela presença de aditivos, a concentração polimérica, o método de obtenção, além de propriedades intrínsecas dos polímeros, como grau de cristalinidade dentre outros fatores [76].

O controle e domínio de tais parâmetros permite controle da nanoestrutura formada, levando a modificações nas propriedades da rede polimérica [16], como a cinética de liberação específica de fármacos e, propriedades mecânicas específicas, como a macroporosidade e a integridade física da membrana.

O estudo da densidade de reticulação, bem como a determinação de outros parâmetros de rede, permitem uma avaliação precisa sobre a estrutura do material desenvolvido, o que está diretamente relacionada com as propriedades finais do produto [77]. 


\section{MATERIAIS E MÉTODOS}

\subsection{MATERIAIS}

\subsubsection{EQUIPAMENTOS}

Os seguintes equipamentos foram utilizados durante a pesquisa:

- $\quad$ Acelerador linear (6 MeV) ELU-6 - Linac Eksma ${ }^{\circledR}$

- $\quad$ Autoclave vertical $415-$ Fanem $^{\circledR}$

- $\quad$ Balança analítica BP121S - Sartorius ${ }^{\circledR}$

- $\quad$ Banho termostatizado Q-226N1 - Quimis $^{\circledR}$

- $\quad$ Câmara de Neubauer 9020-01 - HBG ${ }^{\circledR}$

- $\quad$ Câmera de segurança biológica SBIIA-1266/4 classe II A1 - Filterflux ${ }^{\circledR}$

- $\quad$ Centrífuga refrigerada $5804 \mathrm{R}$ - Eppendorf ${ }^{\circledR}$

- $\quad$ Citômetro de fluxo C6 - Accuri ${ }^{\circledR}$

- Dosímetro de Alanina e-Scan - Bruker ${ }^{\circledR}$

- $\quad$ Espectrofotômetro de microplacas Multiskan EX Microplate - Thermo Scientific ${ }^{\circledR}$

- $\quad$ Espectrofotômetro UV/Vis Cary 300 - Varian ${ }^{\circledR}$

- $\quad$ Estufa para secagem $520-$ Fanem $^{\circledR}$

- $\quad$ Estufa incubadora de $\mathrm{CO}_{2}$ Orion 520 - Fanem $^{\circledR}$

- $\quad$ Extrator Soxhlet - Vidrolabor ${ }^{\circledR}$

- $\quad$ Fluorímetro F-4500 - Hitachi ${ }^{\circledR}$ 
- $\quad$ Freezer $\left(-18^{\circ} \mathrm{C}\right) \mathrm{CVT} 10 \mathrm{BBBN}-$ Consul $^{\circledR}$

- $\quad$ Homogeneizador 723 - Fisatom ${ }^{\circledR}$

- Incubadora refrigerada TE-421 - Tecnal ${ }^{\circledR}$

- Incubadora tipo Shaker TE-420 - Tecnal ${ }^{\circledR}$

- $\quad$ Irradiador GammaCell fonte ${ }^{60} \mathrm{Co}$ - Atomic Energy of Canada Limited ${ }^{\circledR}$

- $\quad$ Liofilizador, modelo Dura Stop - TDS 3 Dura Dry - FTS Systems ${ }^{\circledR}$

- $\quad$ Microscópio eletrônico de varredura XL $30-$ Phillips $^{\circledR}$

- Microscópio Invertido de campo claro e escuro TMS - Nikon ${ }^{\circledR}$

- $\quad$ Paquímetro digital de precisão 100.280 (Resolução de 0,01 mm) Digimess $^{\circledR}$

- $\quad$ pHmetro DL 15 Titrator - Mettler Toledo ${ }^{\circledR}$

- $\quad$ Seladora à vácuo - SINBO $\left(\right.$ Registron $\left.{ }^{\circledR}\right)$

- $\quad$ Termoformadora SR $200000-$ Croydon $^{\circledR}$

\subsubsection{REAGENTES ANALÍTICOS}

Os reagentes empregados na pesquisa correspondem à:

- $\quad$ Ácido acético glacial $100 \%$, P.A. - Synth ${ }^{\circledR}$

- $\quad$ Ácido clorídrico 37\%, P.A. - Synth ${ }^{\circledR}$

- $\quad$ Ágar Muller Hinton - Difco ${ }^{\circledR}$

- $\quad$ Água de osmose reversa

- $\quad$ Albumina de Soro Bovina - Sigma Aldrich ${ }^{\circledR}$

- $\quad$ Álcool terc-butílico - Merck ${ }^{\circledR}$ 
- $\quad$ Anticorpo monoclonal lgG de cabra conjugado com peroxidase (HRPconjugated anti-goat lgG) - Sigma-Aldrich ${ }^{\circledR}$

- $\quad$ Anticorpo de cabra policlonal anti-Carica papaya (LS-C59235) - LSbio ${ }^{\circledR}$

- $\quad$ Argônio (>99.9\%) - Praxair $^{\circledR}$

- $\quad$ Azul de Tripan - Sigma-Aldrich ${ }^{\circledR}$

- $\quad \beta$-ciclodextrina - Sigma Aldrich ${ }^{\circledR}$

- $\quad$ Kit de citocinas CBA (Cytometry Bead Array) - BD Biosciences ${ }^{\circledR}$

- $\quad$ Cloreto de sódio P.A. - Synth ${ }^{\circledR}$

- $\quad$ Cloridrato de L-cisteína monohidratado - Synth ${ }^{\circledR}$

- $\quad$ Cloridrato de Na-benzoil-DL-arginina p-nitroanilida - Sigma Aldrich ${ }^{\circledR}$

- $\quad$ Dimetil- $\beta$-ciclodextrina - Sigma Aldrich ${ }^{\circledR}$

- $\quad$ Dimetilsulfóxido - Synth ${ }^{\circledR}$

- $\quad$ Etilenodiaminotetracetato de sódio - Merck ${ }^{\circledR}$

- $\quad$-(2-hidroxipropil)- $\beta$-ciclodextrina - Sigma ${ }^{\circledR}$

- $\quad$ Histopaque - Sigma Aldrich ${ }^{\circledR}$

- $\quad$ Fosfato de sódio dibásico heptahidratado - Synth ${ }^{\circledR}$

- $\quad$ Gel de Aristoflex ${ }^{A V C}-$ PharmaSpecial $^{\circledR}$

- $\quad$ Heptakis (2,6-di-O-metil)-ß-ciclodextrina - Sigma Aldrich ${ }^{\circledR}$

- Hidrogenocarbonato de sódio P. A. $100 \%$ - Synth ${ }^{\circledR}$

- $\quad$ Hidróxido de sódio P.A. $100 \%$ - Synth ${ }^{\circledR}$

- $\quad$ Metil- $\beta$-ciclodextrina - Sigma Aldrich ${ }^{\circledR}$

- $\quad$ Meio de cultura DMEM - Gibco ${ }^{\circledR}$

- $\quad$ Meio de cultura RPMI $1640-$ Gibco $^{\circledR}$ 
- $\quad$ Meio de cultura TSA (Trypic soy Agar soybean-casein digest agar) USP 23 - Acumedia $^{\circledR}$

- $\quad$ Meio de cultura TSB (tryptic soybroth Soybean-casein digest medium) BactoTM $^{\circledR}$

- $\quad$ Meio de cultura antibiótico $n^{0} 1-$ Acumedia $^{\circledR}$

- $\quad$ Meio de cultura antibiótico no $11-$ Acumedia $^{\circledR}$

- $\quad$ Metanol P. A. - Synth ${ }^{\circledR}$

- $\quad$ MTT (3-(4,5-Dimethylthiazol-2-yl)-2,5-Diphenyltetrazolium Bromide) Sigma Aldrich ${ }^{\circledR}$

- $\quad$ N-dimetilformamida - Sigma Aldrich ${ }^{\circledR}$

- $\quad$ Substrato para peroxidase (o-phenylenediamine dihydrochloride OPD Sigma Fast) - Sigma-Aldrich ${ }^{\circledR}$

- $\quad$ Disco de ouro $(99,99 \%)$ de $60 \mathrm{~mm}$ de diâmetro e $3 \mathrm{~mm}$ de espessura Ted Pella ${ }^{\circledR}$

- $\quad$ Óxido nitroso (>99\%) - Praxair $^{\circledR}$

- Papaína (30000 USP-U/mg) para fins bioquímicos - Merck $^{\circledR}$

- $\quad$ Pellets de Alanina - Brucker $^{\circledR}$

- $\quad$ Polivinil álcool (Celvo ${ }^{\circledR} 325$, grau de hidrólise 98.4\%) - Sigma Aldrich ${ }^{\circledR}$

- $\quad$ Polivinilpirrolidona (PVP K90) - Sigma Aldrich ${ }^{\circledR}$

- $\quad$ Polietilenoglicol 400 P.A. - Synth ${ }^{\circledR}$

- $\quad$ Soro fetal bovino - Merck ${ }^{\circledR}$

- $\quad$ Trealose - Sigma Aldrich ${ }^{\circledR}$

- $\quad$ Tween 20 - Sigma Aldrich ${ }^{\circledR}$

- Violeta de Genciana - Sigma Aldrich ${ }^{\circledR}$ 


\subsubsection{ANIMAIS, LINHAGENS CELULARES E MICROORGANISMOS}

As linhagens e cepas celulares, bem como os microrganismos empregados na pesquisa estão descritos abaixo:

- $\quad$ Esplenócitos de camundongo (Swiss)

- $\quad$ Candida albicans (ATCC 10231) - ATCC $^{\circledR}$

- Células mononucleares do sangue periférico

- $\quad$ Escherichia coli (ATCC 25922) - ATCC $^{\circledR}$

- $\quad$ Escherichia coli (ATCC 8739) - ATCC $^{\circledR}$

- $\quad$ BALB/3T3 clone A31 (ATCC ${ }^{\circledR}$ CCL-163 ${ }^{\text {TM }}$ ) - ATCC ${ }^{\circledR}$

- $\quad$ Klebsiella pneumoniae (cepa selvagem)

- $\quad$ Pseudomonas aeruginosa (ATCC 9027) - ATCC $^{\circledR}$

- $\quad$ Pseudomonas aeruginosa (cepa selvagem)

- $\quad$ Staphylococcus aureus (ATCC 25923) - ATCC $^{\circledR}$

- Staphylococcus aureus (ATCC 6538) - ATCC $^{\circledR}$ 


\subsection{MÉTODOS}

\subsubsection{DESENVOLVIMENTO DE COMPLEXO DE PAPAÍNA E CICLODEXTRINA}

O desenvolvimento do complexo de papaína e ciclodextrina foi realizado englobando desde os estudos computacionais até a síntese, caracterização físicoquímica e biológica do complexo.

\subsubsection{ESTUDOS COMPUTACIONAIS}

Os estudos computacionais foram realizados visando determinar parâmetros estruturais como a área acessível ao solvente (AAS), a área acessível ao solvente fracionada (AASf) e a disposição dos aminoácidos na estrutura da papaína, visando compreender as possíveis implicações da estrutura da papaína na formação do complexo.

\section{ÁREA ACESSÍVEL POR SOLVENTE}

As áreas acessíveis foram calculadas baseando-se em um peptídeo fornecido pelo programa VADAR - Volume, Area, Dihedral Angle Reporter [78], cuja sequência corresponde à Gly-Xaa-Gly na posição phi=180 e psi=-180. Cada um dos 20 aminoácidos foi substituído na posição Xaa. $\mathrm{A}$ área de cada átomo do resíduo foi calculada utilizando o ANAREA [79] a partir do raio atômico de SHRAKE [80]. O volume de cada resíduo foi obtido utilizando o programa VOLUME [81].

Os cálculos foram realizados considerando os dados obtidos por ensaios de RMN e Raios-X de alta resolução [8] disponíveis na base de dados de proteínas Protein Data Base (PDB) - (código 9pap.pdb - 1.65Å). Os seguintes parâmetros foram utilizados: raio de van der Waals (van der Waals radii) obtido de [80]; e as pontes de hidrogênio consideradas como para molécula de água. 
A área acessível fracionada foi determinada através da divisão do valor da área acessível por solvente referente ao resíduo, pelo valor da AAS do resíduo localizado no tripeptídeo Gly-Xaa-Gly, utilizando o programa VADAR.

\section{DISPOSIÇÃO DOS AMINOÁCIDOS}

A representação gráfica das estruturas, bem como da área acessível por solvente, foi realizada utilizando o programa Jmol v. 12.0.4.1. [82]. Os valores referentes à acessibilidade ao solvente, calculados para cada aminoácido presente na estrutura da papaína, foram obtidos no VADAR, conforme descrito acima.

\subsubsection{DETERMINAÇÃO DOS PARÂMETROS FÍSICO-QUÍMICOS ADEQUADOS PARA COMPLEXAÇÃO}

Com a finalidade de determinar as condições mais propícias à formação do complexo, o processo de encapsulamento molecular foi realizado utilizando parâmetros como tempo e concentração de ciclodextrina. As amostras foram, então, submetidas aos ensaios de caracterização.

Os efeitos das concentrações de $\beta$-ciclodextrina ( $\beta: C D)$ na atividade biológica, bem como nas propriedades físico-químicas da papaína foram avaliados nas proporções molares de 1-200 ฤMol. $\mathrm{mL}^{-1}$ (papaína/ $\beta$-ciclodextrina). As alíquotas foram submetidas à incubação e coletadas em função do tempo, sendo divididas em avaliação inicial (0-120 minutos), e prolongada (0-48 horas) sob temperatura ambiente. Após cada tempo, as alíquotas foram avaliadas por fluorescência e quanto à atividade enzimática da papaína.

Após determinados os parâmetros de síntese (tempo de 24 horas e proporção molar de 1:10), os complexos foram novamente sintetizados utilizando ciclodextrinas modificadas, como a dimetil- $\beta: C D$ (dm- $\beta: C D)$, metil- $\beta: C D$ (m- $\beta: C D)$, hidroxipropil$\beta: C D(h p-\beta: C D)$ e trealose. 


\subsubsection{SÍNTESE DO COMPLEXO}

Em solução-tampão fosfato $(\mathrm{pH}=6,0)$ foram acrescentadas a papaína e a $\beta: C D$ dm- $\beta: C D, m-\beta: C D$, hp- $\beta: C D$ ou trealose, na proporção molar de 1:10. O processo de complexação foi realizado em incubadora refrigerada, sob agitação mecânica de 80 rpm e temperatura ambiente, determinados de acordo com cada condição avaliada. As amostras foram avaliadas novamente por fluorescência quanto a evidências da complexação, e o ensaio de atividade enzimática, visou a busca por alterações na atividade enzimática da papaína.

\section{ESTADO SÓLIDO}

O complexo de papaína e $\beta-C D$ (1:10) contendo uma concentração de papaína de $5 \mathrm{mg} \cdot \mathrm{mL}^{-1}$ foi coletado após incubação por 24 horas sob temperatura ambiente e congelado utilizando nitrogênio líquido. Após essa etapa, o complexo congelado foi submetido ao processo de liofilização por 72 horas. O material liofilizado foi então selado e armazenado em freezer $\left(-20^{\circ} \mathrm{C}\right)$.

\subsubsection{CARACTERIZAÇÃO FÍSICO-QUÍMICA DO COMPLEXO}

A caracterização físico-química do complexo foi realizada por meio de análises de espectrofotometria na faixa ultravioleta (UV) e de fluorescência.

UV

Amostras dos complexos selecionadas para análise de fluorescência foram submetidas previamente à leitura em espectrofotômetro no comprimento de onda fixo de $280 \mathrm{~nm}$ e, posteriormente, diluídas em tampão para ajustar o conteúdo proteico, considerando valores equivalentes de absorbância. 


\section{FLUORESCÊNCIA}

As amostras de papaína e do complexo, coletadas em função do tempo (0-48 horas), foram submetidas a análises de fluorescência utilizando um comprimento de onda de excitação $\left(\lambda_{E x}\right)$ de $280 \mathrm{~nm}$ e varrendo a emissão $\left(\lambda_{E m}\right)$ de 300-400 nm, Ex $x_{\text {slit }}$ de $5 \mathrm{~nm}$ e Emslit de $10 \mathrm{~nm}$, com fenda de $1 \mathrm{~cm}$ e velocidade de varredura (scan speed) de $240 \mathrm{~nm} \cdot \mathrm{min}^{-1}$.

\subsubsection{CARACTERIZAÇÃO BIOLÓGICA DO COMPLEXO}

As análises realizadas para caracterização biológica do complexo de papaína e ciclodextrina corresponderam aos ensaios de atividade enzimática, ensaios de citotoxicidade, imunogenicidade e capacidade de ligação com anticorpo específico.

\section{DOSEAMENTO DA ATIVIDADE ENZIMÁTICA}

A quantificação da atividade enzimática da papaína e do complexo foi realizada em placas de 96 poços, utilizando como substrato específico o cloridrato de benzoil DL-arginina $\rho$-nitroanilida (BAPA). A reação foi realizada por 45 minutos a $40^{\circ} \mathrm{C}$, em banho termostatizado, utilizando ácido acético $10 \%(\mathrm{v} / \mathrm{v})$ para interromper a reação. A $\rho$-nitroanilina liberada foi estimada colorimetricamente, utilizando-se de leitora de microplacas, na faixa de $405 \mathrm{~nm}[83,84]$.

\section{CITOTOXICIDADE}

\section{Queratinócitos humanos}

Os queratinócitos humanos foram fornecidos pelo Banco de Tecidos do Instituto Central do Hospital das Clínicas da Faculdade de Medicina da Universidade de São Paulo, obtidos por cirurgia plástica de redução de mama, sob responsabilidade do Dr. André Oliveira Paggiaro e Dra. Monica Beatriz Mathor. As células foram extraídas pela técnica da desagregação enzimática [85]. O registro de 
aprovação do comitê de ética para utilização das células humanas no estudo corresponde ao CAAE 00927912.7.0000.5421.

As células foram transferidas $\left(2 \times 10^{4}\right.$ célula/poço) para placa de 96 poços e incubadas em estufa a $37^{\circ} \mathrm{C}, 5 \% \mathrm{CO}_{2}$ por 24 horas. As amostras foram adicionadas (0.02-1 mg/poço) e, após estímulo de $24 \mathrm{~h}$, aproximadamente $120 \mu \mathrm{L}$ de meio de cultura foram adicionados ao sistema, visando neutralizar/minimizar a ação da papaína. As placas foram, então, mantidas em estufa a $37{ }^{\circ} \mathrm{C}, 5 \% \mathrm{CO}_{2}$ por 10 minutos, centrifugadas por mais 10 minutos a $1000 \mathrm{rpm}$ e retornaram para a estufa por 4 horas. Após esse período, o meio foi aspirado e $120 \mu \mathrm{L}$ de meio de cultura contendo MTS [86] foi adicionado a cada poço. Decorridas 2 horas, a leitura das placas foi realizada em comprimento de onda fixo de $490 \mathrm{~nm}$. O cálculo de viabilidade celular foi realizado conforme EQUAÇÃO 2, onde $D O=$ densidade ótica.

$\%$ Viabilidade celular $=\frac{(\text { DO células Tratadas }- \text { Do branco })}{(\text { DO controle negativo }- \text { DO branco })} * 100$

Células Mononucleares do Sangue Periférico

A coleta de sangue periférico $(15 \mathrm{~mL})$ foi realizada utilizando voluntários saudáveis, entre 20 e 30 anos, sem uso de medicamentos nem ingestão de bebidas alcoólicas, mediante assinatura de termo de consentimento, através de punção venosa utilizando frascos com heparina. As células mononucleares do sangue periférico (PBMC) foram isoladas utilizando o Ficoll-Hypaque, lavadas e diluídas em meio RPMI. O registro de aprovação do Comitê de Ética em Pesquisas com Seres Humanos para utilização destas células no estudo corresponde ao CEP 176/08.

A suspensão celular foi transferida para placas de 96 poços na ordem de $1 \times 10^{6}$ células por poço, e, em seguida, as amostras foram adicionadas e as placas acondicionadas em estufa a $37^{\circ} \mathrm{C}$ e $5 \% \mathrm{CO}_{2}$ por períodos de 24 e 72 horas. Após cada período determinado, foram adicionados $10 \mu \mathrm{L}$ de MTT (5 mg. $\mathrm{ml}^{-1}$ em PBS) por poço e as placas foram novamente colocadas na estufa por 4 horas, seguida da adição de $50 \mu \mathrm{L}$ de tampão de bloqueio (N-dimetilformamida) por poço e, incubação em estufa por 12 horas. A leitura foi, então, realizada em leitora de microplacas, 
utilizando o comprimento de onda fixo de $592 \mathrm{~nm}$. O cálculo de viabilidade celular foi realizado conforme EQUAÇÃO 2.

\section{ENSAIOS DE IMUNOGENICIDADE}

Avaliação da ligação antígeno-anticorpo

Análises de Elisa foram realizadas em triplicata, em placas de 96 poços. Os poços foram sensibilizados por 12 horas utilizando $1 \mu \mathrm{g}$ de amostra contendo papaína pura ou complexo por poço em $50 \mu \mathrm{L}$ de solução-tampão carbonato $\left(0,1 \mathrm{M} \mathrm{NaHCO}_{3}\right.$, $\mathrm{pH} 8,6$ ) a $4{ }^{\circ} \mathrm{C}$. Os poços foram lavados com PBS contendo $0,05 \%$ de Tween 20 (PBS-T) e, então, bloqueados com $3 \%$ albumina de soro bovino (BSA) em PBS por $1 \mathrm{~h}$ a $37^{\circ} \mathrm{C}$, seguido de 5 lavagens com PBS-T e incubação com o anticorpo de cabra policlonal anti-Carica papaya previamente diluído (1:5000 in BSA/PBS) por uma hora a $37^{\circ} \mathrm{C}$. A placa foi novamente lavada por 5 vezes com PBS-T e incubada com o antiIgG conjugado com peroxidase diluído em (1:1000) BSA/PBS. As amostras foram reveladas utilizando substrato para peroxidase e as leituras realizadas a $490 \mathrm{~nm}$ em leitora de microplacas.

\section{Dosagem de citocinas}

As células do compartimento peritoneal de camundongos Swiss foram coletadas através de lavagem peritoneal utilizando $5 \mathrm{~mL}$ de PBS. Após centrifugação por 10 minutos a $4000 \mathrm{rpm}$, sob temperatura de $25^{\circ} \mathrm{C}$, foi realizada nova lavagem utilizando tampão de lise celular. Após centrifugação e lavagem com PBS, as células foram quantificadas utilizando câmara de Neuebauer e Azul de Tripan.

Os esplenócitos, $\left(1 \times 10^{6}\right.$ células por poço) foram cultivados em placas de 96 poços, utilizando meio de cultura RPMI suplementado a $37^{\circ} \mathrm{C}$ em atmosfera contendo $5 \% \mathrm{CO}_{2}$. As células foram estimuladas com a papaína pura, irradiada, o complexo e o hidrogel, sendo incubadas por um período de 5 dias em estufa a $37{ }^{\circ} \mathrm{C}$ e $5 \% \mathrm{CO}_{2}$. O meio RPMI foi trocado a cada 12 horas. O registro de aprovação no Comitê de Ética 
na Utilização de Animais da Universidade Federal de Uberlândia para utilização destas células no estudo corresponde ao CEUA 128/11.

A dosagem de citocinas murinas - Th1/Th2/ Th17 foi realizada utilizando o kit de citocinas CBA. As leituras foram realizadas em triplicata em citômetro de fluxo. A amostragem realizada considerou 2100 eventos para cada análise.

\section{ANÁLISE ESTATÍSTICA}

Os resultados selecionados foram tratados estatisticamente por análise de variância (ANOVA) utilizando o programa STATISTICA, (data analysis software system - StatSoft, Inc.) v. 7.1., e o GraphPad Prisma v.4.0. (GraphPad Software, Inc.). Os resultados foram considerados estatisticamente significativos com $p<0,05$.

\subsubsection{EFEITO DA IRRADIAÇÃO NA PAPAÍNA}

\subsubsection{EFEITOS DIRETOS DA RADIAÇÃO}

A papaína foi irradiada em diferentes meios - pó, solução aquosa, tampão fosfato $\mathrm{pH} 6,0(50 \mathrm{mM})$ contendo cisteína $(0,2 \%, \mathrm{p} / \mathrm{v})$ e gel de aristoflex ${ }^{\mathrm{AVC}}(2 \%, \mathrm{p} / \mathrm{v})$ contendo de cisteína (0,2\% p/v) - sob diferentes doses de radiação (0-25 kGy) em irradiador com fonte de ${ }^{60} \mathrm{Co}$ (Gammacell). As amostras foram avaliadas quanto à atividade enzimática da papaína.

\subsubsection{EFEITOS INDIRETOS DA RADIAÇÃO}

\section{RADIÓLISE DE PULSO}

Os experimentos de radiólise de pulso foram realizados em um acelerador de elétrons linear de $6 \mathrm{MeV}$, gerando pulsos de 7 ns de duração e $20 \mathrm{~Gy}$. A dosimetria do pulso foi realizada pelo método da alanina em um dosímetro para determinação 
da dose utilizada [87]. O sistema de detecção ótica utilizado e tratamento de dados foram realizados conforme descrito na literatura [88].

Espectro do aduto papaína-OH*

A papaína em solução aquosa $(4,2 \times 10-5 \mathrm{~mol} . \mathrm{dm}-3)$ foi submetida a borbulha com $\mathrm{N}_{2} \mathrm{O}$ por 45 minutos e, então, ao processo de irradiação, sob borbulha. Os pulsos foram aplicados e a absorbância foi registrada na faixa de comprimento de onda de $290-500 \mathrm{~nm}$.

Determinação da constante de reação papaína- $\mathrm{OH}^{\bullet}$

Os pulsos foram aplicados à solução aquosa contendo papaína nas concentrações de $1,9 \times 10^{-5}$ até $4,2 \times 10^{-5} \mathrm{~mol}^{-d m^{-3}}$ e as medidas de absorbância foram realizadas no comprimento de onda fixo de $330 \mathrm{~nm}$. A solução aquosa foi tratada com $\mathrm{N}_{2} \mathrm{O}$ conforme descrito acima.

Determinação da constante de reação papaína-e-aq

Em solução aquosa contendo $0,1 \mathrm{~mol}^{-\mathrm{dm}^{-3}}$ de terc-butanol, os pulsos foram aplicados e as medidas de absorbância realizadas no comprimento de onda fixo de $720 \mathrm{~nm}$. A enzima foi adicionada em concentrações variando de $1,4 \times 10^{-5}$ a $4,2 \times 10^{-}$ 5 mol.dm ${ }^{-3}$, e as soluções foram submetidas à borbulha com argônio por 45 minutos previamente à irradiação e mantidas durante o processo.

\subsubsection{IRRADIAÇÃO DA PAPAÍNA E DO COMPLEXO}

EM SOLUÇÃO

A papaína (5 mg.mL $\left.{ }^{-1}\right)$ e o complexo de papaína e $\beta-C D$ na proporção molar de 1:10 foram submetidos à radiação gama em irradiador com fonte de ${ }^{60} \mathrm{Co}$ até atingir 
dose de $10 \mathrm{kGy}$. Estas amostras foram avaliadas quanto à atividade enzimática, ligação antígeno-anticorpo e produção de citocinas.

\section{LIOFILIZADO}

As embalagens contendo o complexo de papaína e $\beta$-CD na proporção molar de 1:10 foram submetidas à irradiação em irradiador com fonte de ${ }^{60} \mathrm{Co}$ até atingir dose de $25 \mathrm{kGy}$, dose capaz de esterilizar materiais [89]. A taxa de dose variou entre 1,2 a $1,5 \mathrm{kGy} \cdot \mathrm{h}^{-1}$. As amostras foram mantidas congeladas (em $\mathrm{CO}_{2}$ sólido) durante toda a exposição aos raios gama. Após a irradiação, a atividade enzimática da papaína foi quantificada conforme descrito para o complexo.

\subsubsection{DESENVOLVIMENTO DO HIDROGEL CONTENDO COMPLEXO DE PAPAÍNA E CICLODEXTRINA}

\subsubsection{SÍNTESE DO HIDROGEL}

A síntese do hidrogéis foi realizada pela técnica de reticulação e esterilização simultânea utilizando radiação ionizante desenvolvida por Rosiak e colaboradores [19]. Para o hidrogel à base de PVA, ciclos térmicos foram realizados previamente à técnica de reticulação e esterilização simultânea.

\section{HIDROGEL À BASE DE PVP}

O preparo das formulações a serem estudadas foi realizado através da solubilização e homogeneização dos componentes em água de osmose reversa sob aquecimento com auxílio de homogeneizador. Após resfriamento da solução até 
temperaturas não inferiores a $40{ }^{\circ} \mathrm{C}$, a papaína, cisteína e/ou complexo foram adicionados sob agitação manual, equivalente a $0,5 \%$ (p/p) de papaína.

Após solubilização total dos componentes, o conteúdo foi vertido em embalagens de polipropileno termoformadas, que foram seladas em seladora à vácuo (FIGURA 22) e submetidas à irradiação gama.
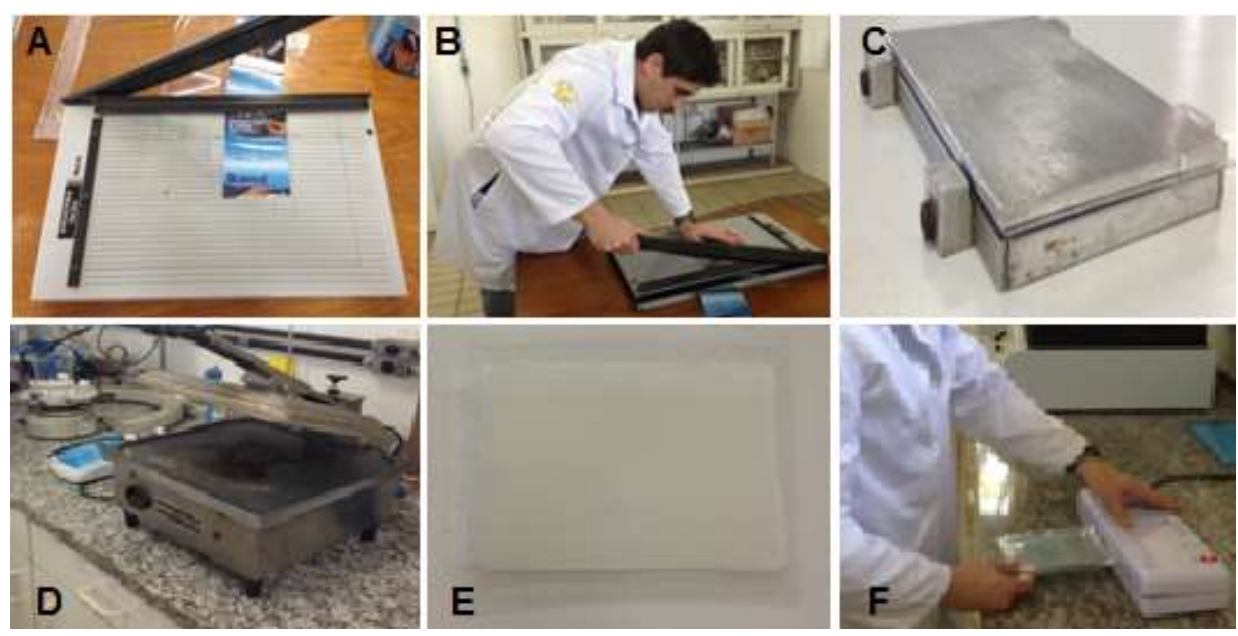

FIGURA 22 - Esquema de produção dos hidrogéis, considerando que: A - Preparo dos filmes; B - corte dos filmes; C - moldagem dos filmes; D - termoformagem dos berços; $\mathbf{E}$ - solução de polímero vertida no berço pronto; $\mathbf{F}$ - selagem a vácuo.

A composição das formulações utilizadas para produção dos hidrogéis à base de PVP está descrita na TABELA 2.

TABELA 2 - Formulações-base do hidrogéis à base de PVP.

\begin{tabular}{lcccc}
\hline & \multirow{2}{*}{ Formulações } & \multicolumn{3}{c}{ Composição (\%, p/p) } \\
\cline { 2 - 5 } & PVP & PEG & Agar \\
\hline F-1A & 6 & 0 & 0 \\
F-2A & 6 & 1,5 & 0 \\
F-3A & 6 & 5 & 0 \\
F-1B & 6 & 0 & 0,5 \\
F-2B & 6 & 1,5 & 0,5
\end{tabular}


TABELA 2 - Formulações-base do hidrogéis à base de PVP (continuação).

\begin{tabular}{lccc} 
F-3B & 6 & 5 & 0,5 \\
F-1C & 6 & 0 & 1,5 \\
F-2C & 6 & 1,5 & 1,5 \\
F-3C & 6 & 5 & 1,5 \\
F-1D & 15 & 0 & 0 \\
F-2D & 15 & 1,5 & 0 \\
F-3D & 15 & 5 & 0 \\
F-1E & 15 & 0 & 0,5 \\
F-2E & 15 & 1,5 & 0,5 \\
F-3E & 15 & 5 & 0,5 \\
F-1F & 15 & 0 & 1,5 \\
F-2F & 15 & 1,5 & 1,5 \\
F-3F & 15 & 5 & 1,5 \\
\hline
\end{tabular}

HIDROGEL À BASE DE PVA

O PVA e os outros componentes foram adicionados sob agitação utilizando homogeneizador e submetidos a autoclavagem utilizando autoclave vertical por 3045 minutos para solubilização adequada dos componentes descritos na TABELA 3. A adição da papaína e/ou do complexo e da cisteína foi realizado conforme descrito para os hidrogéis a base de PVP.

Aproximadamente $10 \mathrm{~mL}$ do conteúdo foram, então, vertidos nas embalagens termoformadas, as quais foram seladas a vácuo e submetidas ao ciclo térmico, que consistiu no congelamento das amostras a $-20^{\circ} \mathrm{C}$ por 24 horas, seguido de descongelamento sob temperatura ambiente por 24 horas. 
TABELA 3 - Formulações dos hidrogéis para veiculação do complexo à base de PVA.

\begin{tabular}{llllllllll}
\hline & \multicolumn{7}{c}{ Formulações (\%, p/p) } \\
\cline { 2 - 9 } Componentes & A & B & C & D & E & F & G & Controle \\
\hline PVA & 10 & 10 & 10 & 10 & 10 & 10 & 10 & 10 \\
Ágar & 1 & 1 & 1 & 1 & 1 & 1 & 1 & 1 \\
PEG 400 & 1,5 & 1,5 & 1,5 & 1,5 & 1,5 & 1,5 & 1,5 & 1,5 \\
Papaína & 2 & 2 & 2 & 2 & 2 & 2 & 2 & - \\
Cisteína & 0,2 & 0 & 0,6 & - & - & 0,2 & 0,2 & - \\
B-Ciclodextrina & 0 & 0 & 0 & 0,96 & - & 0,96 & - & - \\
Trealose & 0 & 0 & 0 & 0 & 0,29 & 0 & 0,29 & - \\
Água O.R. & Qsp & Qsp & Qsp & Qsp & Qsp & Qsp & Qsp & Qsp \\
\hline
\end{tabular}

O.R.= Osmose Reversa; Qsp = Quantidade suficiente para.

IRRADIAÇÃO DO HIDROGEL

As amostras previamente congeladas foram submetidas à radiação gama em irradiador com fonte de ${ }^{60} \mathrm{Co}$, até atingir dose de $25 \mathrm{kGy}$. A taxa de dose variou entre 1,2 a 1,5 kGy.h-1. As amostras foram mantidas congeladas (em $\mathrm{CO}_{2}$ sólido) durante toda a exposição à radiação.

\subsubsection{CARACTERIZAÇÃO DA FORMA FARMACÊUTICA}

DETERMINAÇÃO DAS DIMENSÕES DO HIDROGEL

Parâmetros como espessura, comprimento e largura foram realizados utilizando paquímetro digital de precisão. A amostragem foi realizada utilizando 3 membranas de cada formulação produzida, selecionadas de modo aleatório. 


\section{DETERMINAÇÃO DA MASSA}

A determinação da massa do hidrogel foi realizada individualmente utilizando balança digital analítica. A amostragem foi realizada conforme supracitado e as massas registradas correspondem aos valores médios obtidos.

\section{FRAÇÃO GEL}

Amostras de $0,5 \mathrm{~g}$ foram secas em estufa a $50{ }^{\circ} \mathrm{C}$ até peso constante, embaladas em non woven e colocadas em soxhlet contendo água por 48 h. Após extração, as membranas foram secas novamente até peso constante, conforme estabelecido pela norma [90]. Os resultados de fração gel foram tratados utilizando as EQUAÇÕES 3 e 4.

$$
\begin{aligned}
& F \boldsymbol{S}(\%)=\frac{m f-m i}{m i} \\
& F \boldsymbol{g}(\%)=100-F S
\end{aligned}
$$

Considerando que: $F s$ = fração solúvel; $F g$ = fração gel; $m i$ = massa inicial da amostra seca $\mathrm{e} ; \mathrm{mf}=$ massa final da amostra seca.

\section{INTUMESCIMENTO MÁXIMO}

Amostras de $0,3 \mathrm{~g}$ do hidrogel foram imersas em água de osmose reversa e retiradas, posteriormente, em intervalos regulares de tempo até atingir massa constante. $O$ ensaio foi realizado de acordo com a norma vigente [90]. O grau de intumescimento foi calculado conforme descrito na EQUAÇÃO 5. 


$$
I(\%)=\frac{m f-m i}{m i} * 100
$$

Considerando que: $\mathrm{I}=$ Intumescimento $(\%) ; \mathrm{I}=$ Valor de Intumescimento $(\%) ; \mathrm{mi}=$ massa inicial da amostra seca e; $\mathrm{mf}=$ massa da amostra intumescida.

\section{CARACTERIZAÇÃO NANOESTRUTURAL}

Densidade de reticulação

A caracterização nanoestrutural foi realizada por meio da avaliação da densidade de reticulação e do tamanho de poro. Os valores de intumescimento máximo em equilíbrio foram tratados segundo a equação de Flory-Rehner [77], indicando a densidade de reticulação.

O valor de $X$ é correspondente à fração do volume molar do polímero, e é determinado utilizando as EQUAÇÕES 6 e 7, a partir dos valores de intumescimento máximo obtidos:

$$
\begin{aligned}
& I=\frac{(m f-m i)}{m i} * \frac{d p}{d s} \\
& \chi=1 /(1+I)
\end{aligned}
$$

Considerando que: $\mathrm{I}$ = razão de Intumescimento; $\mathrm{mi}$ = massa inicial da amostra seca; $\mathrm{mf}=$ massa da amostra intumescida; $d_{s}$ à densidade do solvente $\mathrm{e} ; d_{p}$ à densidade do polímero. 
Após obtenção de tais valores, foi então aplicada a EQUAÇÃO 8:

$$
\boldsymbol{q}=[\boldsymbol{\operatorname { l n }}(\mathbf{1}-\chi)+\chi+\mu \cdot \chi \mathbf{2}+\boldsymbol{p} \cdot \boldsymbol{v}] / M c \cdot(\chi 1 / 3-0,5 \chi)^{*} m
$$

Considerando que: $x=$ fração do volume molar do polímero intumescido; $p=$ densidade do polímero; $v$ = volume molar do solvente; $m=$ volume molar das unidades monoméricas na cadeia do polímero; $M c=$ média de massa molar entre as cadeias reticuladas do polímero; $\mu=$ valor de interação entre polímero e solvente, e; $q=$ densidade de reticulação em mol.cm ${ }^{-3}$.

\section{CARACTERIZAÇÃO MORFOLÓGICA}

\section{Microscopia eletrônica de varredura}

Amostras dos hidrogéis com $0,1 \mathrm{~g}$ foram previamente secas em estufa na temperatura de $25{ }^{\circ} \mathrm{C}$, e então, acondicionadas em frasco fechado a vácuo. As amostras foram fixadas em um suporte e recobertas com ouro e, após este processo, observadas utilizando microscópio eletrônico de varredura.

\section{AVALIAÇÃO DA LIBERAÇÃO IN VITRO DE PAPAíNA E DO COMPLEXO}

\section{Ensaio de liberação in vitro}

A avaliação da liberação da papaína e do complexo no hidrogel foi realizada utilizando Incubadora tipo Shaker. Amostras selecionadas dos hidrogéis, cortadas em pedaços de $1 \times 1 \times 0,33 \mathrm{~cm}^{3}$ e aproximadamente $0,3 \mathrm{~g}$ foram imersas em solução fisiológica $(0,9 \% \mathrm{NaCl}), \mathrm{pH} 7,4$ e temperatura de $37^{\circ} \mathrm{C}$. Alíquotas de $2 \mathrm{~mL}$ foram coletadas nos tempos determinados e avaliadas quanto ao conteúdo proteico e a atividade enzimática, com subsequente reposição do meio extrator. $O$ teste foi realizado em triplicata. 
Quantificação do conteúdo proteico

As alíquotas coletadas envolvendo período de 48 horas foram filtradas, utilizando filtros para seringa de 0,45 $\mu \mathrm{m}$, e analisadas por espectrofotometria UV, utilizando espectrofotômetro UV/vis no comprimento de onda fixo de $280 \mathrm{~nm}$.

\section{Doseamento da atividade enzimática}

O doseamento da atividade enzimática foi realizado a partir das alíquotas retiradas para quantificação do conteúdo proteico, de maneira idêntica ao doseamento realizado para a atividade da papaína no complexo.

\section{AVALIAÇÃO DO POTENCIAL ANTIMICROBIANO DO HIDROGEL}

\section{Ensaio de inibição microbiana}

A avaliação das propriedades antimicrobianas, ou ensaio de inibição microbiana dos hidrogéis à base de PVA desenvolvidos foi realizada de acordo com [91], utilizando as seguintes cepas microbianas: Staphylococcus aureus (ATCC 6538 e ATCC 25923), Klebsiella pneumoniae (linhagem selvagem), Pseudomonas aeruginosa (ATCC 9027 e linhagem selvagem), Candida albicans (ATCC 10231), e Escherichia coli (ATCC 8739 e ATCC 25922), utilizando o método de difusão em ágar.

Para esse teste, o método escolhido foi o de bicamada sendo que em placas de Petri foram adicionados $15 \mathrm{~mL}$ de meio TSA e $5 \mathrm{~mL}$ de meio Antibiótico 11 [91] onde foram inoculados $106 \mathrm{UFC} / \mathrm{cm}^{2}$ de cada microrganismo testado (E. coli, $C$. Albicans, $S$. aureus e $P$. aeruginosa). Os hidrogéis previamente cortados em forma circular foram esterilizados utilizando radiação UV por 5 minutos cada lado e posicionados sobre o ágar na placa de Petri. As placas foram incubadas por 24 horas a uma temperatura de $35^{\circ} \mathrm{C}$ para as bactérias e $25^{\circ} \mathrm{C}$ para a levedura. Após esse período foi efetuada a leitura dos halos de inibição formados utilizando paquímetro para cada amostra.

Os seguintes microrganismos Staphylococcus aureus (ATCC 25923), Pseudomonas aeruginosa (cepa selvagem), Klebsiella pneumoniae (cepa selvagem), 
Escherichia coli (ATCC 25922) foram cultivados utilizando ágar Muller Hinton e plaqueados conforme supracitado.

\section{AVALIAÇÃO DA CITOTOXICIDADE DO HIDROGEL}

A avaliação da citotoxicidade do hidrogel foi realizada por meio de testes de citotoxicidade direta, cujos efeitos são resultantes do contato direto do hidrogel com as células, e testes de toxicidade indireta, cujas células ficam em contato com líquido extrator contendo os possíveis componentes tóxicos extraídos do hidrogel. O procedimento foi realizado utilizando PBMC.

\section{Citotoxicidade direta}

Os hidrogéis previamente cortados em fluxo laminar com dimensões de aproximadamente $3 \mathrm{~mm}$ de diâmetro foram esterilizados em radiação UV por 15 minutos cada lado e transferidos para cada poço da microplaca.

\section{Citotoxicidade indireta}

As membranas, previamente esterilizadas por radiação UV foram mantidas em meio extrator, meio de cultura e DMEM acrescido de $10 \%$ de soro bovino, por 6 horas a $70{ }^{\circ} \mathrm{C}$, conforme estabelecido [92] e foram realizadas diluições seriadas utilizando meio de cultura, de modo a atingir as concentrações de 25-100 \%, para serem então submetidos ao contato com as células.

\section{AVALIAÇÃO DA IMUNOGENICIDADE DO HIDROGEL}

Dosagem de citocinas

Os hidrogéis foram avaliados quanto à capacidade de induzir a produção de citocinas, conforme descrito para avaliação da resposta imunológica do complexo. As 
células foram expostas aos hidrogéis à base de PVA e suas extrações realizadas conforme descrito para o ensaio de citotoxicidade.

\section{AVALIAÇÃO DAS PROPRIEDADES DE ADESÃO CELULAR}

\section{Ensaio de adesão celular}

Para determinar o potencial de adesão celular dos hidrogéis, fibroblastos de Balb/c 3T3 foram cultivados em garrafas (passagem 17) com meio de cultura DMEM suplementado com $10 \%$ de soro fetal bovino utilizando incubadora úmida com $5 \%$ de $\mathrm{CO}_{2}$ e $37{ }^{\circ} \mathrm{C}$ por 24 horas. Após atingir $80 \%$ de confluência, as células foram descoladas da garrafa de cultura com auxílio de um removedor de células (cell scraper).

Os hidrogéis previamente esterilizados conforme descrito nos ensaios de citotoxicidade foram transferidos para placa estéril de 12 poços. Aproximadamente 50.000 células foram inseridas em cada poço em meio de cultura (DMEM suplementado com $10 \%$ de soro fetal bovino) e subsequentemente incubadas por 4 horas a $37^{\circ} \mathrm{C}$. Os hidrogéis foram retirados dos poços e transferidos para outra placa.

A fixação das células foi realizada utilizando metanol, considerando 5 minutos de contato, e lavagem com PBS pH 7,2. Após fixação, as células foram coradas com violeta de genciana e os hidrogéis foram visualizados em microscópio ótico invertido. O controle positivo correspondeu às células e o negativo, a um poço vazio. 


\section{RESULTADOS E DISCUSSÃO}

\subsection{DESENVOLVIMENTO DO COMPLEXO}

Para desenvolvimento do complexo de papaína e ciclodextrina foram realizadas avaliações das implicações estruturais da enzima na formação do complexo, efeito da concentração de ciclodextrina e tempo de complexação, visando determinar as condições adequadas para síntese.

\subsubsection{IMPLICAÇÕES DA ESTRUTURA PROTEICA NA FORMAÇÃO DO COMPLEXO}

\subsubsection{AVALIAÇÃO DA ESTRUTURA DA PAPAÍNA}

Para um estudo específico sobre a estrutura molecular da enzima, assim como sobre a disposição dos aminoácidos na molécula, foi estimada a distribuição das subestruturas proteicas, onde observou-se um predomínio das folhas- $\beta$ sobre a ocorrência da $\alpha$-hélices (TABELA 4), além da ocorrência de voltas ( $\beta$ turns) e zonas que não apresentam estrutura secundária definida (random coil).

TABELA 4 - Distribuição das subestruturas proteicas na molécula de papaína.

\begin{tabular}{lcc}
\hline Estrutura secundária & Ocorrências & Porcentagem (\%) \\
\hline Helix & 58 & 27 \\
Beta & 69 & 32 \\
Random Coil & 84 & 39 \\
Voltas $\beta$ & 28 & 13 \\
\hline * Cálculos realizados considerando o raio atômico obtido de [80].
\end{tabular}


A seguir, foram avaliadas as ligações de hidrogênio (TABELA 5) e a ocorrência e distribuição dos ângulos diédricos (TABELA 6).

TABELA 5 - Ligações de hidrogênio presentes na estrutura da papaína.

\begin{tabular}{lll}
\hline Parâmetro & Calculados & Esperado* \\
\hline Distância média $(\mathrm{A})$ & $2,2 \pm 0.4$ & $2,2 \pm 0.4$ \\
Energia média $(\mathrm{kcal} / \mathrm{mol})$ & $-1,7 \pm 1.0$ & $-2,0 \pm 0.8$ \\
Resíduos com Lig. H & $148(70 \%)$ & $158(75 \%)$ \\
\hline
\end{tabular}

*Valores esperados obtidos de [93]; Lig. - Ligação, H - Hidrogênio.

Os ângulos diédricos permitem avaliar a possibilidade de acesso ao solvente e definir as regiões específicas onde a combinação dos ângulos Phi e Psi de cada unidade peptídica apresentam ou não colisões estéricas entre átomos dos aminoácidos envolvidos [81].

TABELA 6 - Valores calculados e teóricos para os ângulos diédricos presentes na estrutura da papaína.

\begin{tabular}{lll}
\hline Estatística & Observado & Teórico* \\
\hline Helix Phi médio & $-68,6( \pm 14.2)$ & $-65,3( \pm 11,9)$ \\
Helix Psi médio & $-37,3( \pm 13.3)$ & $-39,4( \pm 25,5)$ \\
res com Gauche+ Chi & $79(49 \%)$ & $87(55 \%)$ \\
res com Gauche- Chi & $25(15 \%)$ & $31(20 \%)$ \\
res com Trans Chi & $55(34 \%)$ & $39(25 \%)$ \\
Chi Gauche+ médio & $-62,3( \pm 18.0)$ & $-66,7( \pm 15,0)$ \\
Chi Gauche- médio & $59,1( \pm 18,2)$ & $64,1( \pm 15,7)$ \\
Chi Trans médio & $168,1( \pm 12,4)$ & $168,6( \pm 16,8)$ \\
Desvio padrão de chi & 16,11 & 15,70 \\
Média Omega $(>90)$ & $-179,8( \pm 5,4)$ & $180,0( \pm 5,8)$
\end{tabular}


TABELA 6 - Valores calculados e teóricos para os ângulos diédricos presentes na estrutura da papaína (continuação).

Resíduos com (<90) $\quad 1(0 \%)$

* Valores obtidos por [95].

\subsubsection{INTERAÇÃO PROTEÍNA SOLVENTE}

A avaliação da interação proteína-solvente fornece informações específicas sobre a estrutura da proteína, permitindo uma análise da interação de cada aminoácido presente na molécula com o solvente, considerando as possíveis implicações da estrutura proteica [81]. Os resultados a seguir são baseados na estrutura da papaína obtida por raio-X com resolução de 1,65 A [8].

A representação gráfica dos resultados obtidos com relação a avaliação estrutural da papaína e sua interação com o solvente estão representadas abaixo (FIGURA 23).

A
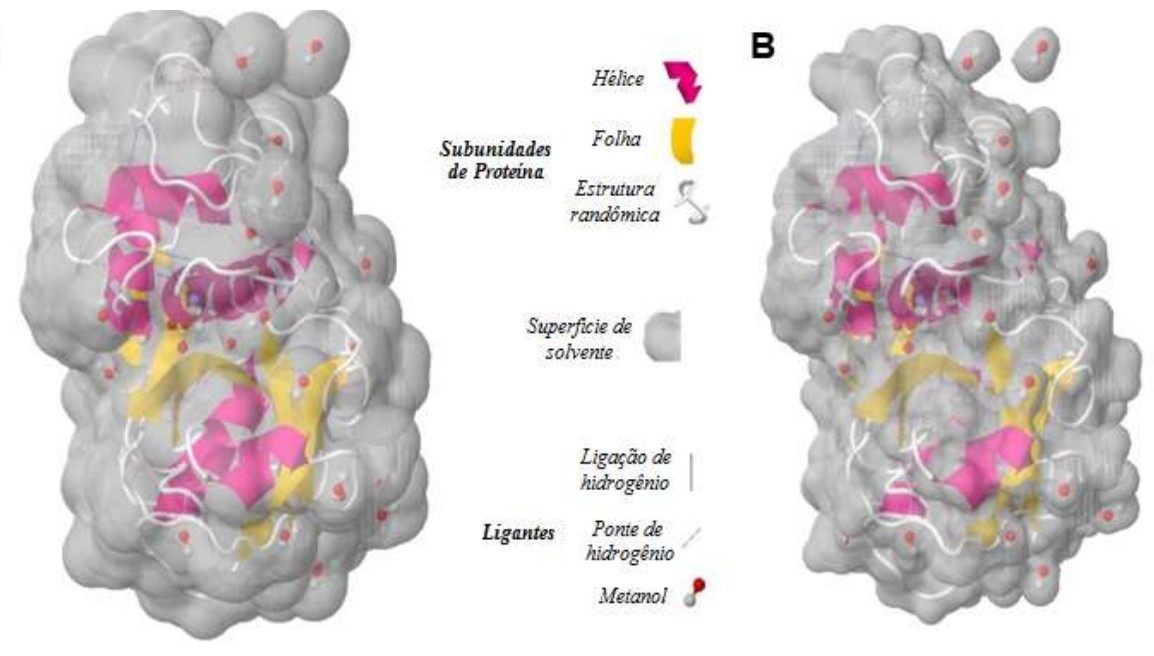

Superficie inacessivel por solvente

Superficie acessivel por solvente (Raio de Van der Waals + Sonda de 1,4 angstrons)

(Sonda de 1,4 angstrons)

FIGURA 23 - Representação gráfica da Interação papaína-solvente, considerando que: $\mathbf{A}$ - superfície acessível ao solvente (considera a área obtida pela sonda de 1,4 angstrons + o raio de Van der Walls); $\mathbf{B}$ - superfície inacessível por solvente (toda a área situada dentro dos limites da área obtida por uma sonda de 1,4 angstrons). 
A superfície do solvente, relacionada a interface papaína-solvente foi obtida e está representada graficamente a seguir (FIGURA 24).

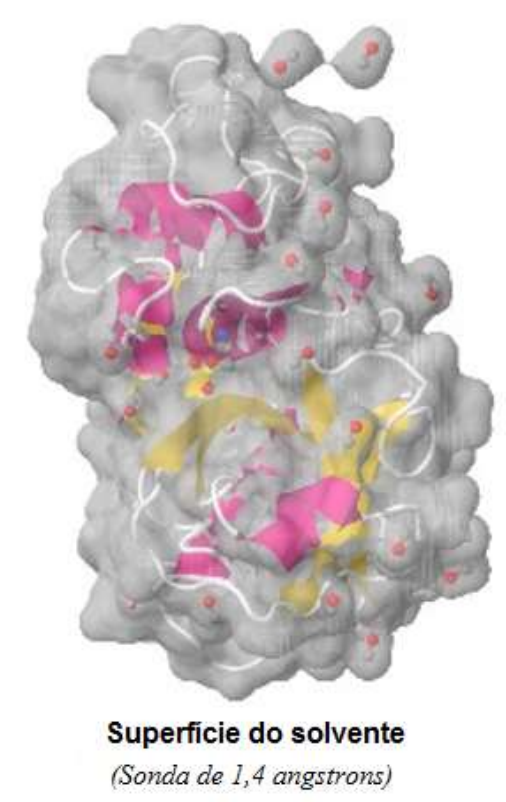

FIGURA 24 - Representação gráfica da superfície de solvente (interface papaínasolvente correspondente aos limites da área obtida por uma sonda de 1,4 angstroms)

A área acessível por solvente da papaína (TABELA 7) foi calculada considerando os valores estimados com relação aos dados descritos nas TABELAS 5 e 6. Observa-se uma AAS total de $9142,3 \AA^{2}$, onde $7842,2 \AA^{2}$ são atribuídos à cadeia lateral, e $1300,1 \AA^{2}$ à estrutura proteica (backbone).

A determinação da AAS da papaína revela que $5126,8 \AA^{2}$ e $5127,3 \AA^{2}$ correspondem à região exposta e cadeia lateral respectivamente, onde $1220,2 \AA^{2} \mathrm{e}$ $1134,2 \AA^{2}$ correspondem à porção com carga (TABELA 7). 
TABELA 7 - Área de superfície acessível por solvente da molécula de papaína.

\begin{tabular}{lll}
\hline $\begin{array}{l}\text { ÁREA ACESSíVEL AO } \\
\text { SOLVENTE }\end{array}$ & CALCULADO & TEÓRICO* \\
\hline AAS total & & \\
AAS da estrutura (backbone) & $1300,1 \AA^{2}$ & $9726,2 \AA^{2}$ \\
AAS das cadeias laterais & $7842,2 \AA^{2}$ & - \\
AAS do C & $5161,2 \AA^{2}$ & - \\
AAS of N & $11132 \AA^{2}$ & - \\
AAS of N & - \\
AAS of O & $529,2 \AA^{2}$ & - \\
AAS of O- & $2155,1 \AA^{2}$ & - \\
AAS do S & $161,8 \AA^{2}$ & - \\
Exposta apolar & $21,8 \AA^{2}$ & - \\
Exposta polar & $5126,8 \AA^{2}$ & $5576,8 \AA^{2}$ \\
Exposta com carga & $2795,3 \AA^{2}$ & $1828,5 \AA^{2}$ \\
Cadeia lateral apolar & $1220,2 \AA^{2}$ & $1737,0 \AA^{2}$ \\
Cadeia lateral polar & $5127.3 \AA^{2}$ & - \\
Cadeia lateral c/ carga & $1580.7 \AA^{2}$ & - \\
Fracionada apolar & $1134.2 \AA^{2}$ & - \\
Fracionada polar & 0.56 & $0.61( \pm 0.03)$ \\
Fracionada c/ carga & 0.31 & $0.20( \pm 0.05)$ \\
Média residual & 0,13 & $0,19( \pm 0,05)$ \\
Média fracionada & $43,3 \AA^{3}$ & - \\
\hline Valores esperados & 0,2 & - \\
\hline
\end{tabular}

*Valores esperados de acordo com [94].

A porção acessivel apolar corresponde a $11545,5 \AA^{2}$, e a porção lateral a $3888,6 \AA^{2}$ (TABELA 8), frente a um volume total de $27682 \AA^{3}$ (TABELA 9). O peso molecular obtido corresponde a 23.323,21 Da e, apresenta correlação adequada com os dados da literatura, descritos como $23.500 \mathrm{Da}$ [26]. 
TABELA 8 - Área de superfície acessível por solvente para a cadeia lateral (exceto $\mathrm{N}, \mathrm{C}, \mathrm{O})$.

\begin{tabular}{ll}
\hline ÁREA ACESSíVEL AO SOLVENTE & CALCULADO \\
\hline Estendida apolar & $21867,8 \AA^{2}$ \\
Estendida polar & $11545,5 \AA^{2}$ \\
Estendida c/ carga & $3013,3 \AA^{2}$ \\
Cadeia lateral estendida apolar & $21741,3 \AA^{2}$ \\
Cadeia lateral estendida polar & $3888,6 \AA^{2}$ \\
Cadeia lateral estendida c/ carga & $2937,6 \AA^{2}$ \\
\hline
\end{tabular}

É relevante notar que, nos resultados obtidos, alguns parâmetros de cálculo, bem como as áreas atômicas e residuais, apresentam divergências se comparados aos dados apresentados pelos autores pioneiros, tal fato se atribui aos algoritmos empregados que, no respectivo período, eram aproximados, e os dados apresentados possuem menor erro implícito, conforme calculados analiticamente utilizando o programa ANAREA.

TABELA 9 - Volume calculado da molécula de papaína.

\begin{tabular}{lll}
\hline PROPRIEDADE & CALCULADO & TEÓRICO* \\
\hline Volume Total $\left(\mathrm{A}^{3}\right)$ & 27682,0 & 27971,8 \\
Volume residual médio $\left(\mathrm{A}^{3}\right)$ & $131,2 \pm 43,3$ & $125,0 \pm 40,0$ \\
Volume Fracionado médio & $1,0 \pm 0,1$ & $1,0 \pm 0,1$ \\
Peso Molecular $(\mathrm{Da})$ & 23323,21 & $23500^{\star *}$ \\
\hline
\end{tabular}

${ }^{*}[8] ;{ }^{* *}[26]$.

\subsubsection{3 ÁREA ACESSÍVEL AO SOLVENTE FRACIONADA}

A AAS fracionada da papaína apresentada a seguir (FIGURA 25) indica a superfície exposta de cada resíduo da papaína acessível ao contato com moléculas 
de água/solvente. Em geral, índices mais baixos de AAS correspondem aos resíduos hidrofóbicos ou localizados no interior da estrutura, enquanto valores elevados de AAS são atribuídos aos resíduos hidrofílicos ou localizados no exterior [81, 95].

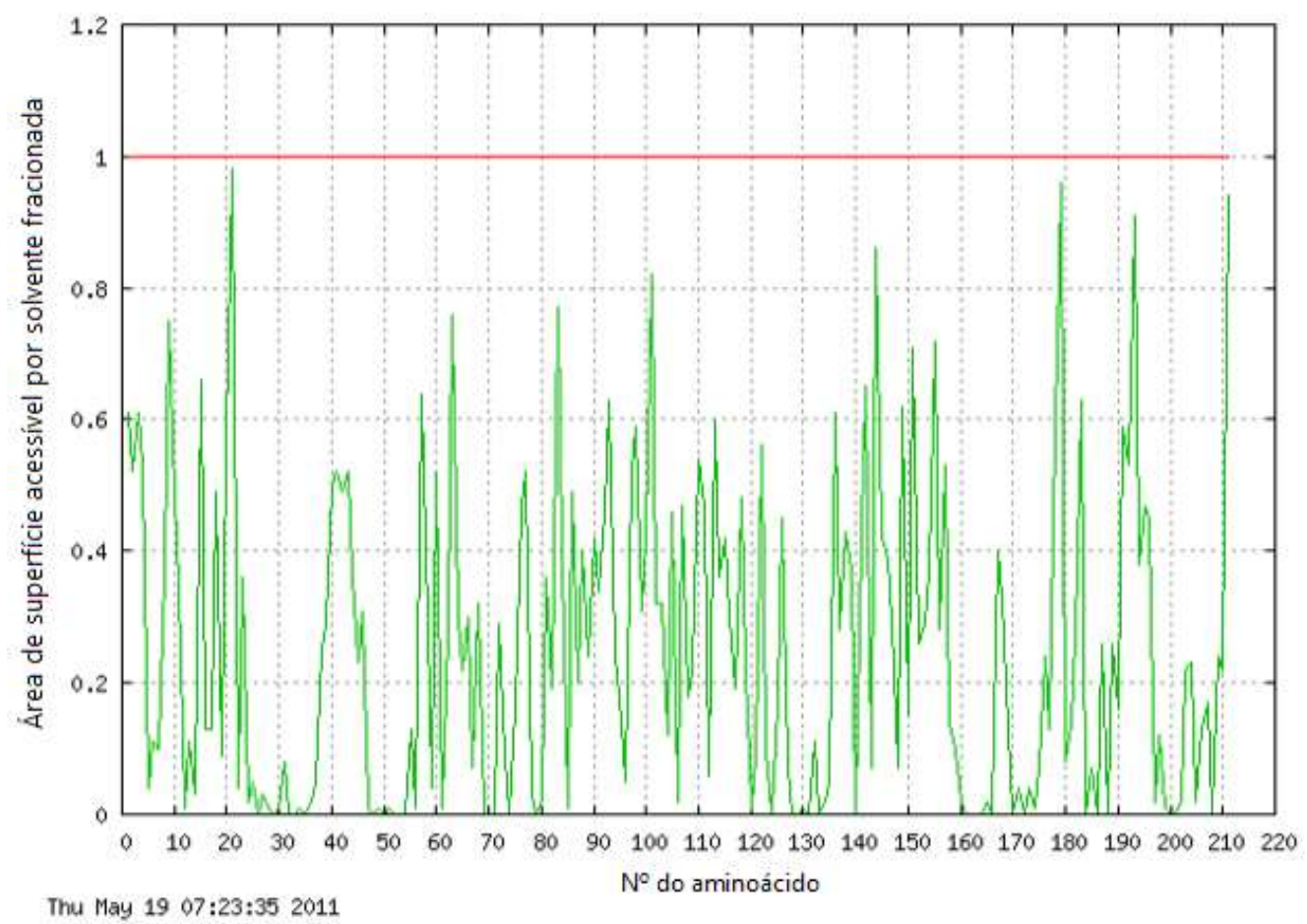

FIGURA 25 - Área acessível por solvente fracionada obtida para a molécula de papaína (9pap.pdb) utilizando o software VADAR.

O perfil apresentado revela uma predominância de resíduos com baixos índices de acessibilidade por solvente, inferiores a 0,5. Por outro lado, alguns resíduos apresentam uma grande área acessível por solvente, indicando que a disposição específica dos resíduos e a estrutura tridimensional da papaína conferem acessibilidade suficiente para permitir interações com as ciclodextrinas.

\subsubsection{DISPOSIÇÃO DOS AMINOÁCIDOS}

Com a finalidade de avaliar a possibilidade de interação da ciclodextrina com cada resíduo passível de complexação, foi realizado um estudo a partir de cada 
aminoácido da papaína fornecendo dados para descrever a formação do complexo, auxiliar na interpretação dos resultados e na seleção das técnicas a serem utilizadas para uma caracterização adequada do complexo formado.

\section{FENILALANINA}

A disposição e a ocorrência dos resíduos de fenilalanina na estrutura da papaína estão descritas na FIGURA 26, e correspondem aos resíduos Phe-28, Phe141, Phe-149 e Phe-207.

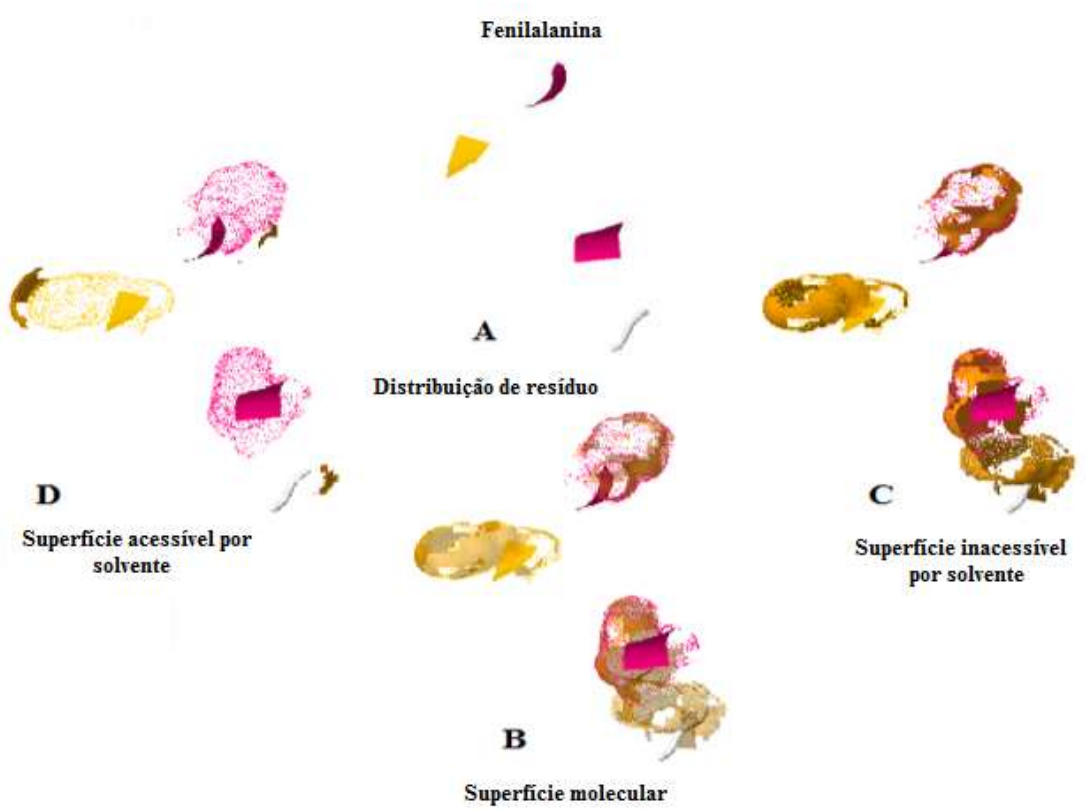

FIGURA 26 - Disposição e interação dos resíduos de fenilalanina presentes na papaína com o solvente, considerando que: A - distribuição dos resíduos; B superfície molecular; C - superfície inacessível por solvente; D - área acessível por solvente.

Conforme observado, a área acessível por solvente para tais resíduos é relativamente pequena (TABELA 10). Os valores estimados para a AAS variam de 6,2 a $29,5 \AA^{2}$, indicando pouca ou nenhuma possibilidade de interação com as 
moléculas de CDs, devido à disposição do aminoácido na estrutura tridimensional da molécula, sendo, portanto, menos suscetíveis à complexação com as ciclodextrinas.

A Phe-207 apresentou o maior índice de AAS entre os resíduos apresentados $\left(29,5 \AA^{2}\right)$; contudo, os resultados indicam baixa acessibilidade geral para estes resíduos devido às implicações bioquímicas impostas pela estrutura proteica da papaína.

TABELA 10 - Análise estrutural dos resíduos de fenilalanina presentes na papaína.

\begin{tabular}{ccccccc}
\hline $\begin{array}{c}\mathbf{N}^{\circ} \\
\text { Resíduo }\end{array}$ & $\begin{array}{c}\text { Estrutura } \\
\text { Secundária }\end{array}$ & $\begin{array}{c}\text { Superfície } \\
\text { lateral } \\
\text { AAS }\end{array}$ & $\begin{array}{c}\text { Superfície } \\
\text { fracionada } \\
\text { AAS }\end{array}$ & AAS & $\begin{array}{c}\text { AAS } \\
\text { fracionada }\end{array}$ & Volume \\
\hline 28 & $\mathrm{H}$ & 6,2 & 0,03 & 6,4 & 0,03 & 204,4 \\
141 & $\mathrm{H}$ & 0,0 & 0,00 & 0,0 & 0,00 & 205,1 \\
149 & $\mathrm{~B}$ & 15,2 & 0,08 & 15,2 & 0,07 & 189,3 \\
207 & $\mathrm{~B}$ & 29,5 & 0,16 & 29,5 & 0,13 & 188,2 \\
\hline \multicolumn{7}{l}{ AAS fracionada - 0,00 a 1,00; AAS - A2; Volume - A33; Hélices - "H"; Folhas $\beta-$ "B"; }
\end{tabular}

TRIPTOFANO

Os resíduos de triptofano encontrados na estrutura da papaína e sua respectiva interação com o solvente estão descritos graficamente na FIGURA 27 e correspondem ao Trp-7, Trp-26, Trp-69, Trp-177 e Trp-181. 


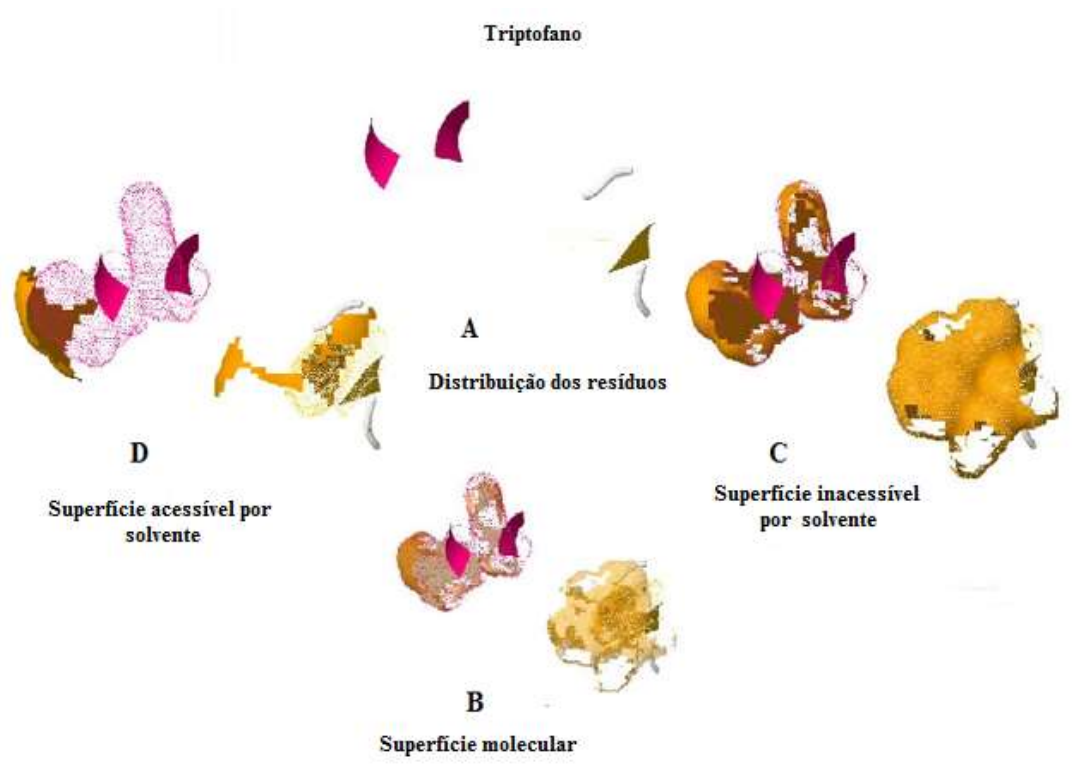

FIGURA 27 - Disposição e interação dos resíduos de triptofano presentes na papaína com o solvente, considerando que: A - distribuição dos resíduos; $\mathbf{B}$ - superfície molecular; C - superfície inacessível por solvente; D - área acessível por solvente.

TABELA 11 - Análise estrutural dos resíduos de triptofano.

\begin{tabular}{ccccccc}
\hline $\begin{array}{c}N^{\circ} \\
\text { Resíduo }\end{array}$ & $\begin{array}{c}\text { Estrutura } \\
\text { Secundária }\end{array}$ & $\begin{array}{c}\text { Superfície } \\
\text { lateral } \\
\text { AAS }\end{array}$ & $\begin{array}{c}\text { Superfície } \\
\text { fracionada } \\
\text { AAS }\end{array}$ & AAS & $\begin{array}{c}\text { AAS } \\
\text { fracionada }\end{array}$ & Volume \\
\hline 7 & B & 27,0 & 0,12 & 27,0 & 0,10 & 246,9 \\
26 & C & 4,0 & 0,02 & 12,8 & 0,05 & 240,8 \\
69 & H & 85,7 & 0,38 & 86,3 & 0,32 & 218,5 \\
177 & C & 50,9 & 0,22 & 64,7 & 0,24 & 213,3 \\
181 & C & 21,1 & 0,09 & 21,1 & 0,09 & 216,9 \\
\hline
\end{tabular}

AAS fracionada - 0.00 a 1,00; AAS - $\AA^{2}$; Volume - $\AA^{3}$; Hélices - "H"; Folhas $\beta$ - "B"; Estruturas não definidas (Coil) - "C";

Os valores da AAS calculados estão descritos na TABELA 11, e, embora apresentem valores relativamente superiores aos resíduos de fenilalanina, variando de 4,0 a $86,3 \AA^{2}$, a possibilidade maior de interação é atribuída apenas a dois resíduos, Trp-69 e Trp-177, localizados nas estruturas $\mathrm{H}$ e $\mathrm{C}$ respectivamente, os quais apresentaram 86,3 e $64,7 \AA^{2}$ de AAS residual, respectivamente. 
De maneira geral, valores de AAS superiores ou equivalentes a $60 \AA^{2}$ indicam acessibilidade ao solvente.

\section{TIROSINA}

Dentre os aminoácidos hidrofóbicos aromáticos presentes na estrutura da papaína está a tirosina, que, além da ocorrência em maior número, apresentou valores superiores da AAS (TABELA 12), indicando que a posição e disposição destes resíduos na molécula permitem uma maior interação entre o aminoácido e o solvente, e, por consequência, a ciclodextrina.

TABELA 12 - Análise estrutural dos resíduos de tirosina presentes na molécula da papaína.

\begin{tabular}{ccccccc}
\hline $\begin{array}{c}\mathbf{N}^{\circ} \\
\text { Resíduo }\end{array}$ & $\begin{array}{c}\text { Estrutura } \\
\text { Secundária }\end{array}$ & $\begin{array}{c}\text { Superfície } \\
\text { lateral } \\
\text { AAS }\end{array}$ & $\begin{array}{c}\text { Superfície } \\
\text { fracionada } \\
\text { AAS }\end{array}$ & AAS & $\begin{array}{c}\text { AAS } \\
\text { fracionada }\end{array}$ & Volume \\
\hline 4 & B & 120,9 & 0,59 & 128,5 & 0,53 & 184,5 \\
48 & B & 2,4 & 0,02 & 2,4 & 0,01 & 208,5 \\
61 & C & 119,9 & 0,59 & 124,8 & 0,52 & 163,8 \\
67 & C & 72,7 & 0,36 & 72,7 & 0,30 & 181,7 \\
78 & H & 122,2 & 0,60 & 126,1 & 0,52 & 180,9 \\
82 & B & 86,1 & 0,42 & 86,1 & 0,36 & 202,7 \\
86 & C & 1,5 & 0,01 & 1,6 & 0,01 & 195,0 \\
88 & C & 26,6 & 0,13 & 49,5 & 0,20 & 184,6 \\
94 & C & 150,9 & 0,74 & 151,6 & 0,63 & 169,2 \\
103 & B & 58,1 & 0,29 & 77,8 & 0,32 & 186,6 \\
116 & C & 88,0 & 0,43 & 101,4 & 0,42 & 169,9 \\
123 & H & 136,3 & 0,67 & 136,3 & 0,56 & 183,5 \\
144 & C & 16,5 & 0,08 & 17,5 & 0,07 & 195,3 \\
166 & B & 4,0 & 0,02 & 4,8 & 0,02 & 216,3 \\
170 & B & 30,6 & 0,15 & 30,6 & 0,13 & 201,9
\end{tabular}


TABELA 12 - Análise estrutural dos resíduos de tirosina presentes na molécula da papaína (Continuação).

$\begin{array}{llccccc}186 & \text { B } & 16,7 & 0,08 & 16,7 & 0,07 & 199,8 \\ 197 & \text { C } & 108,3 & 0,53 & 108,3 & 0,45 & 174,5 \\ 203 & \text { C } & 4,9 & 0,02 & 5,7 & 0,02 & 216,8 \\ 208 & \text { B } & 41,8 & 0,21 & 41,8 & 0,17 & 200,6\end{array}$

AAS fracionada - 0,00 a 1,00; AAS - $\AA^{2}$; Volume - $\AA^{3}$; Hélices - "H"; Folhas $\beta$ - "B"; Estruturas não definidas (Coil) - "C";

Particularmente os resíduos Tyr-4, Tyr-61, Tyr-67, Tyr-78, Tyr-82, Tyr-94, Tyr103, Tyr-116, Tyr-123 e Tyr-197 apresentam valores mais elevados, com alguns valores superiores a $100 \AA^{2}$, indicando que, em geral, os resíduos de tirosina encontram-se mais acessíveis quando comparados com os resíduos de fenilalanina e triptofano. A representação gráfica da interação destes resíduos com o solvente, bem como sua acessibilidade, está na FIGURA 28.

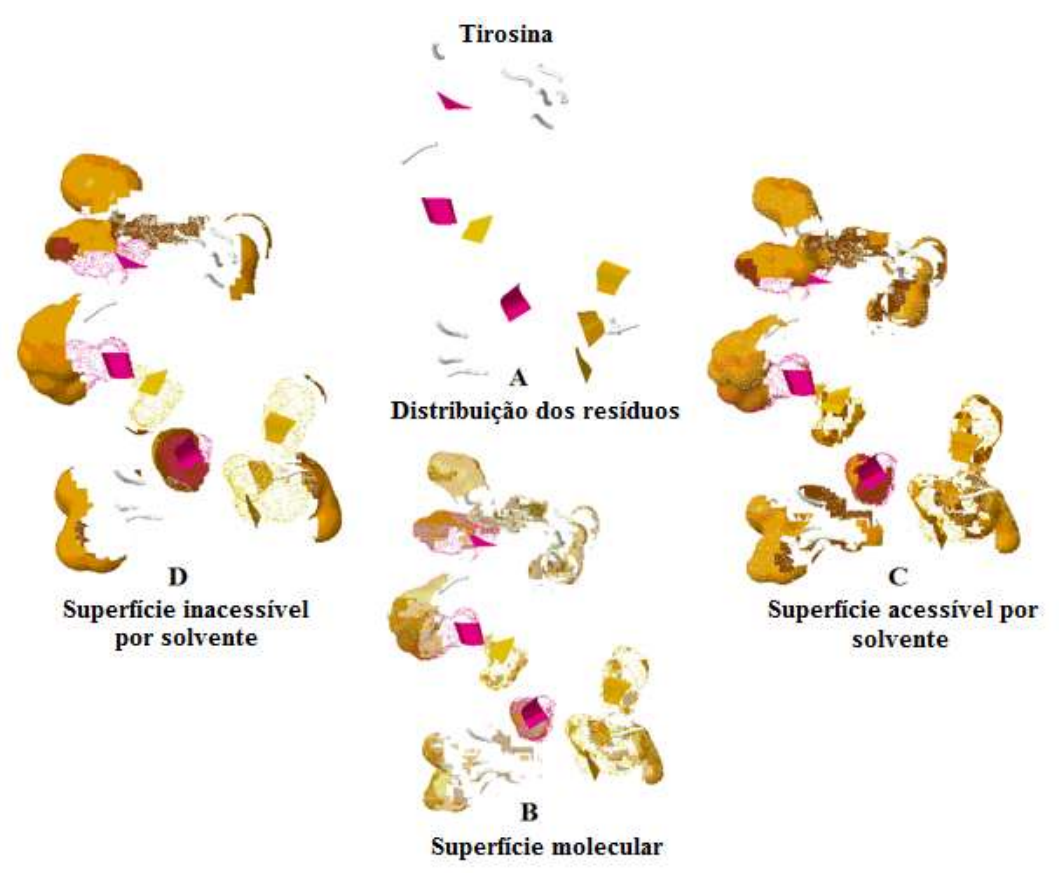

FIGURA 28 - Disposição e interação dos resíduos de tirosina presentes na papaína com o solvente, considerando que: A - distribuição dos resíduos; B - superfície molecular; C - superfície inacessível por solvente; D - área acessível por solvente. 
HISTIDINA

Os resíduos de histidina presentes na molécula de papaína (FIGURA 29), His81 e His-159 apresentam valores de AAS reduzidos (TABELA 13), o que indica baixa acessibilidade.

\section{Histidina}
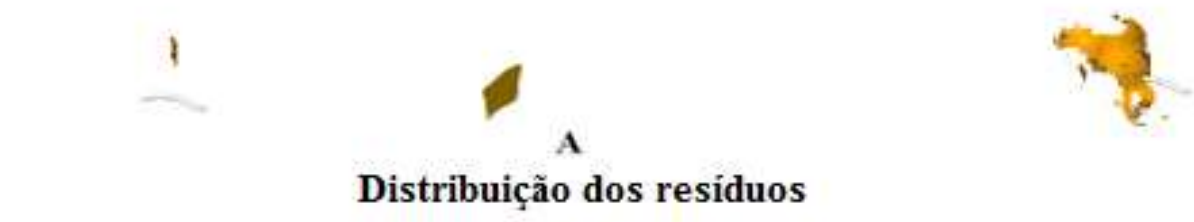

\section{Distribuição dos residuos}

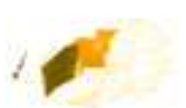

D

Superficie acessivel por solvente

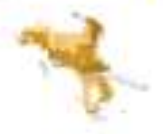

Superfície molecular

FIGURA 29 - Disposição e interação dos resíduos de histidina presentes na papaína com o solvente, considerando que: A - distribuição dos resíduos; B - superfície molecular; C - superfície inacessível por solvente; D - superfície acessível por solvente.

Cabe ressaltar que o resíduo His-159, em particular, faz parte do sítio ativo da enzima, composto por His-159, Cys-25 e Asn-175 e, deste modo, uma complexação neste local poderia acarretar em alterações na interação sítio-ativo/substrato, e que podem refletir diretamente na atividade enzimática. De maneira semelhante, a complexação com resíduos localizados próximos do sítio ativo podem comprometer a atividade enzimática devido ao possível impedimento estérico, capaz de dificultar ou impedir a ligação do substrato com o sítio ativo. 
TABELA 13 - Análise estrutural dos resíduos de histidina presentes na molécula da papaína.

\begin{tabular}{ccccccc}
\hline $\begin{array}{c}N^{\circ} \\
\text { Resíduo }\end{array}$ & $\begin{array}{c}\text { Estrutura } \\
\text { Secundária }\end{array}$ & $\begin{array}{c}\text { Superfície } \\
\text { lateral } \\
\text { AAS }\end{array}$ & $\begin{array}{c}\text { Superfície } \\
\text { fracionada } \\
\text { AAS }\end{array}$ & AAS & $\begin{array}{c}\text { AAS } \\
\text { fracionada }\end{array}$ & Volume \\
\hline 81 & B & 3,8 & 0,02 & 3,8 & 0,02 & 160,3 \\
159 & B & 27,5 & 0,17 & 27,9 & 0,14 & 166,8 \\
\hline
\end{tabular}

AAS fracionada - 0,00 a 1,$00 ;$ AAS - $\AA^{2}$; Volume - $\AA^{3}$; Folhas $\beta$ - "B";

PROLINA

Os resíduos de prolina presentes na molécula de papaína apresentam uma AAS elevada, com exceção dos resíduos Pro-129 e Pro-209 (TABELA 14), que apresentam AAS reduzidas, confirmando a possibilidade da interação destes resíduos com as moléculas de ciclodextrina.

TABELA 14 - Análise estrutural dos resíduos de prolina presentes na papaína.

\begin{tabular}{ccccccc}
\hline $\begin{array}{c}\mathbf{N}^{\circ} \\
\text { Resíduo }\end{array}$ & $\begin{array}{c}\text { Estrutura } \\
\text { Secundária }\end{array}$ & $\begin{array}{c}\text { Superfície } \\
\text { lateral AAS }\end{array}$ & $\begin{array}{c}\text { Superfície } \\
\text { fracionada } \\
\text { AAS }\end{array}$ & AAS & $\begin{array}{c}\text { AAS } \\
\text { fracionada }\end{array}$ & Volume \\
\hline 2 & C & 79,3 & 0,60 & 121,2 & 0,61 & 136,4 \\
15 & C & 102,7 & 0,77 & 102,7 & 0,66 & 109,0 \\
68 & H & 10,9 & 0,08 & 10,9 & 0,07 & 133,3 \\
87 & C & 76,0 & 0,57 & 76,1 & 0,49 & 116,1 \\
102 & C & 120,5 & 0,91 & 127,2 & 0,82 & 109,4 \\
115 & C & 48,3 & 0,36 & 55,5 & 0,36 & 111,6 \\
129 & B & 0,1 & 0,00 & 0,1 & 0,00 & 141,5 \\
152 & C & 107,9 & 0,81 & 109,2 & 0,71 & 121,5 \\
168 & C & 43,8 & 0,33 & 61,9 & 0,40 & 108,8 \\
209 & B & 0,3 & 0,00 & 0,5 & 0,00 & 131,3 \\
\hline
\end{tabular}

AAS fracionada - 0,00 a 1,00; AAS - $\AA^{2}$; Volume - $\AA^{3}$; Hélices - "H"; Folhas $\beta$-"B";

Estruturas não definidas (Coil) - "C"; 
Tais resultados apontam que as implicações da estrutura da papaína na formação de complexos de inclusão com ciclodextrinas acarretam em baixa acessibilidade para fenilalanina, histidina, bem como alguns resíduos de triptofano, e maior acessibilidade para tirosina e prolina. Destaca-se, então, a possibilidade de formação de complexos entre ciclodextrinas e papaína. Os resíduos de prolina e suas interações com o solvente estão representados na FIGURA 30.

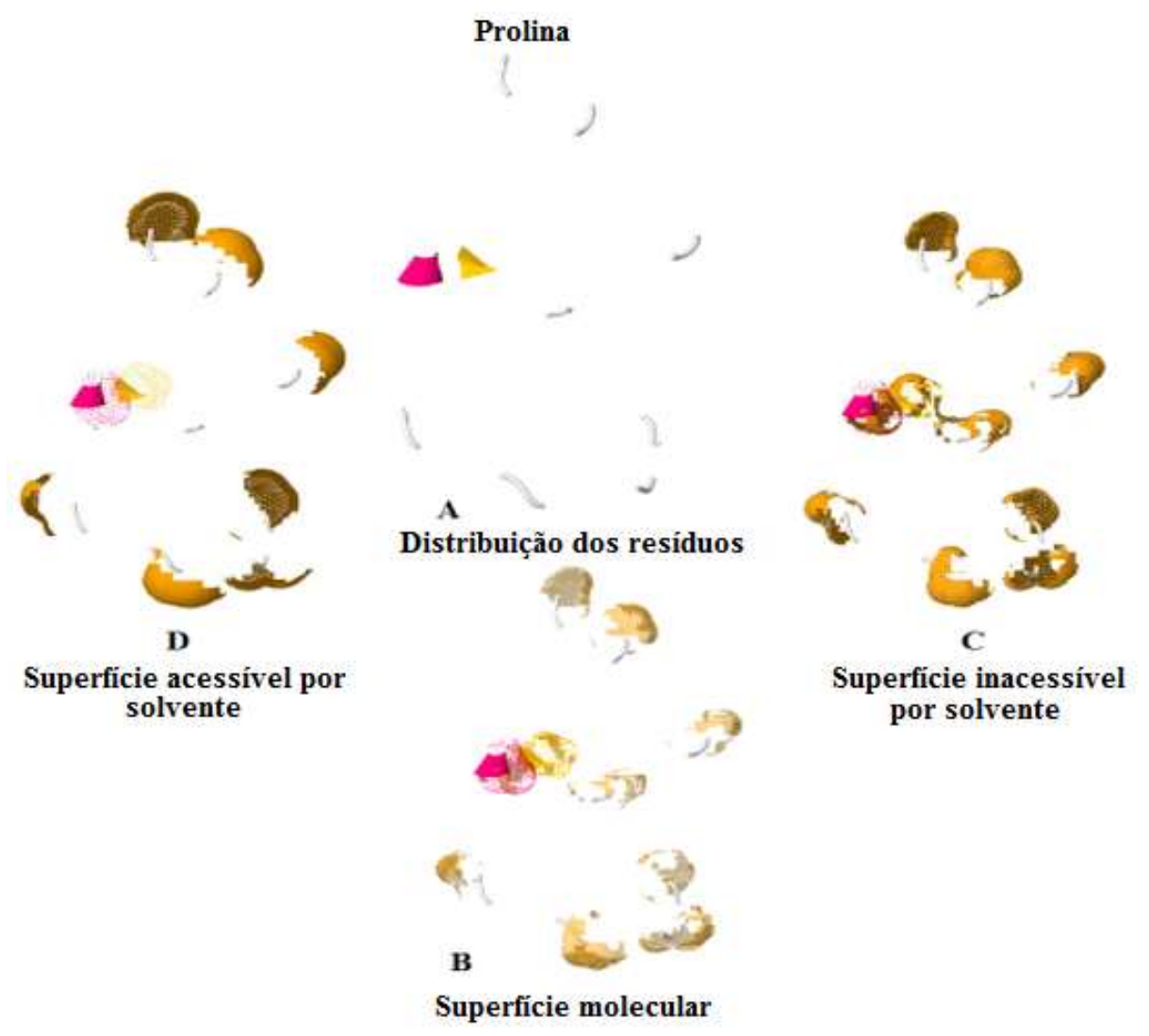

FIGURA 30 - Interação dos resíduos de prolina presentes na papaína com o solvente, considerando que: A - distribuição dos resíduos; B - superfície molecular; C superfície inacessível por solvente; D - superfície acessível por solvente.

\subsubsection{DETERMINAÇÃO DOS PARÂMETROS DE SÍNTESE DO COMPLEXO}

Visando estabelecer a concentração de ciclodextrina adequada para a formação do complexo, o complexo de papaína e $\beta$-ciclodextrina em diferentes 
proporções molares foi avaliado quanto à sua atividade enzimática e perfil de fluorescência.

Após a solubilização dos componentes $(T=0)$, não foram observados efeitos estatísticos sobre a atividade da papaína, considerando a adição de $\beta-C D$ até a proporção molar de 1:50. O perfil de atividade enzimática da papaína na presença da ciclodextrina está contido nas FIGURAS 31 e 32.

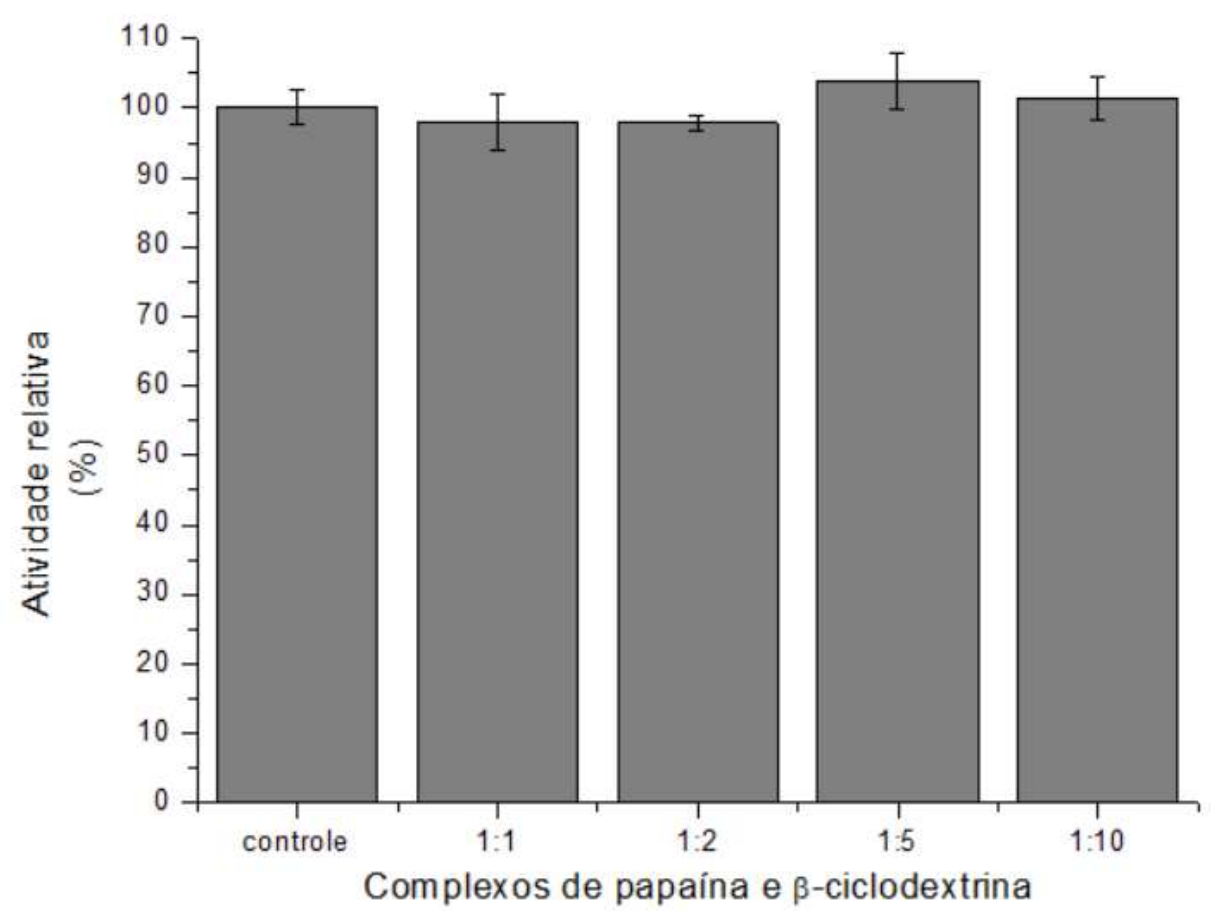

FIGURA 31 - Atividade enzimática da papaína em função da adição de concentrações distintas de ciclodextrina (1-10 $\left.\mathrm{nMol}^{-1}\right)$ após solubilização dos compostos $(\mathrm{T}=0)$.

Em concentrações superiores de ciclodextrina, foi observado uma redução da bioatividade da enzima, conforme os dados apresentados na FIGURA 32. Contudo, os valores só se apresentaram estatisticamente significativos em proporções molares superiores a 1:100.

A literatura reporta que a $C D$ influencia na bioatividade das enzimas, devido à formação do complexo molecular, e que, quando se encontram em altas concentrações, elas tendem a desestabilizar ou denaturar proteínas [56]. Tal efeito é atribuído à formação de complexo com resíduos do sítio ativo ou próximos a ele, de 
modo a impedir total ou parcialmente o encaixe do substrato. Outro fator é a redução da mobilidade.

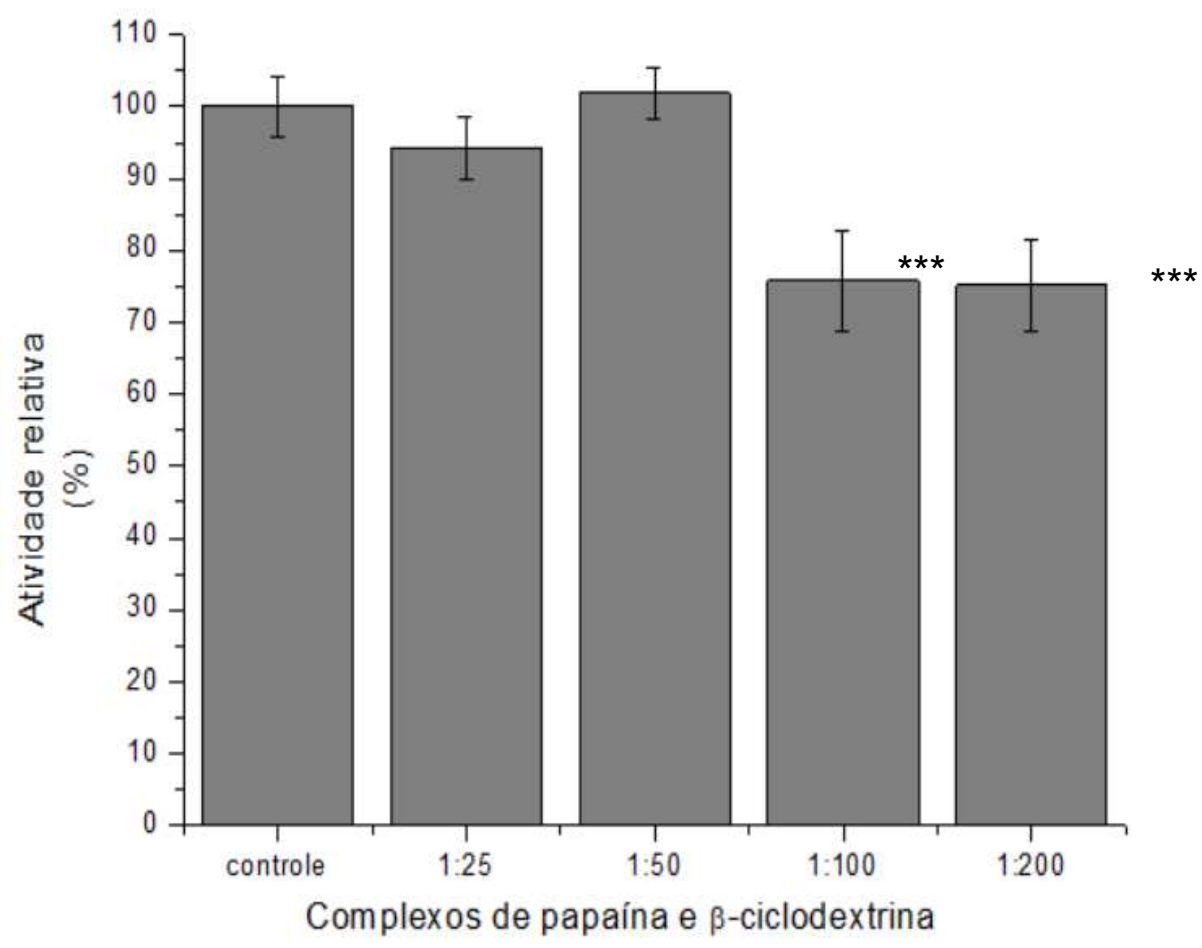

FIGURA 32 - Atividade enzimática da papaína em função da adição de concentrações distintas de ciclodextrina (25-200 $\left.\mathrm{nMol}^{-1}\right)$ após solubilização dos compostos ( $\left.\mathrm{T}=0\right)$.

A avaliação in silico da AAS revelou que, no caso específico da papaína, existem poucas chances de complexação com a his-159 (TABELA 13), e, deste modo, tal efeito sobre a atividade enzimática seria minimizado. Os resultados demonstram que, corroborando os ensaios computacionais, apenas em concentrações muito elevadas de ciclodextrina foi observado o decréscimo de bioatividade.

Almejando uma melhor visualização da influência da ciclodextrina sobre a papaína, os valores de atividade relativa em função das diferentes concentrações de $\beta-C D$ utilizadas foram estimados (FIGURA 33). Destaca-se o fenômeno de hipoativação, que ocorreu para os complexos na proporção molar de 1:100 e 1:200. 


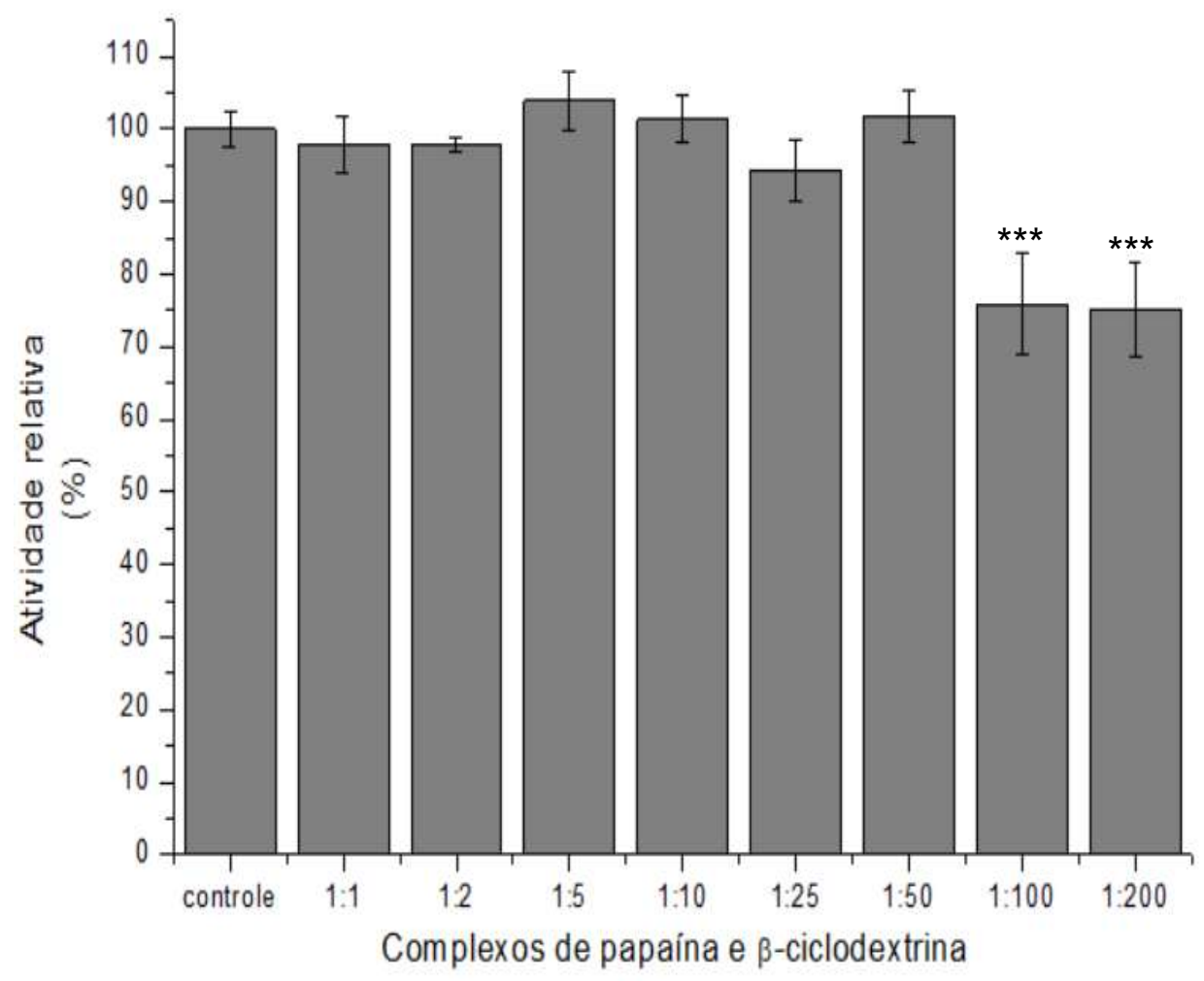

FIGURA 33 - Atividade relativa da papaína (papaína isolada considerado 100\%) em função da concentração de ciclodextrina após solubilização dos compostos.

No momento inicial $(T=0)$, os espectros de emissão de fluorescência obtidos utilizando excitação no comprimento de onda $280 \mathrm{~nm}$, relacionado aos resíduos aromáticos presentes na papaína, revelaram que os complexos quando contrastados com a enzima isolada (FIGURA 34) apresentaram perda significativa de fluorescência, com uma diminuição mais expressiva para a proporção molar de 1:5. 


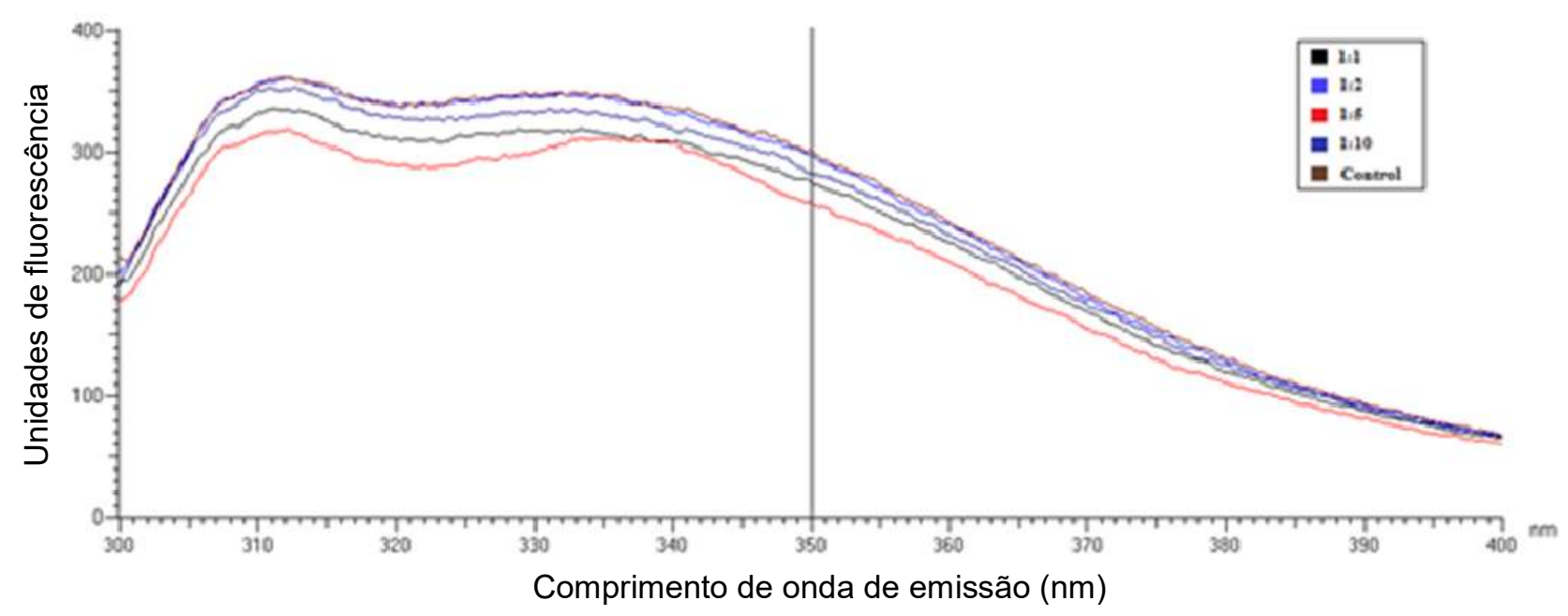

FIGURA 34 - Espectro de fluorescência (300-400 nm) dos complexos de papaína e ciclodextrina após solubilização dos compostos $(\mathrm{T}=0)$.

Tais distinções passam a ser mais pronunciadas com o aumento da concentração de ciclodextrina. Destacam-se as alterações observadas para as concentrações de 5-10 nmol $^{-1}$ de CD.

Corroborando as informações da literatura, bem como os efeitos de hipoativação desencadeados por concentrações maiores de ciclodextrina, os espectros emissão obtidos para estas amostras indicaram que, nas proporções molares superiores a 1:25, as modificações são ainda mais significativas e intensas, possivelmente indicando uma desestabilização da estrutura (FIGURA 35). Cabe ressaltar que não foram registrados deslocamentos de picos, apenas alterações que indicam mudanças no microambiente que envolve os resíduos aromáticos presentes na papaína [96].

De maneira mais específica, as modificações observadas no espectro de fluorescência indicam a ocorrência de dois fenômenos: a formação de uma conformação menos rígida como resultado do aumento da intensidade (1-10 ๆMol) e o desenvolvimento de uma estrutura mais compacta, observada para as concentrações maiores (25-200 ฤMol). Tais mudanças são atribuídas também devido às modificações no microambiente, de natureza mais apolar, gerado ao redor dos aminoácidos encapsulados, neste caso em específico, os resíduos aromáticos - Trp, Phe, His. 


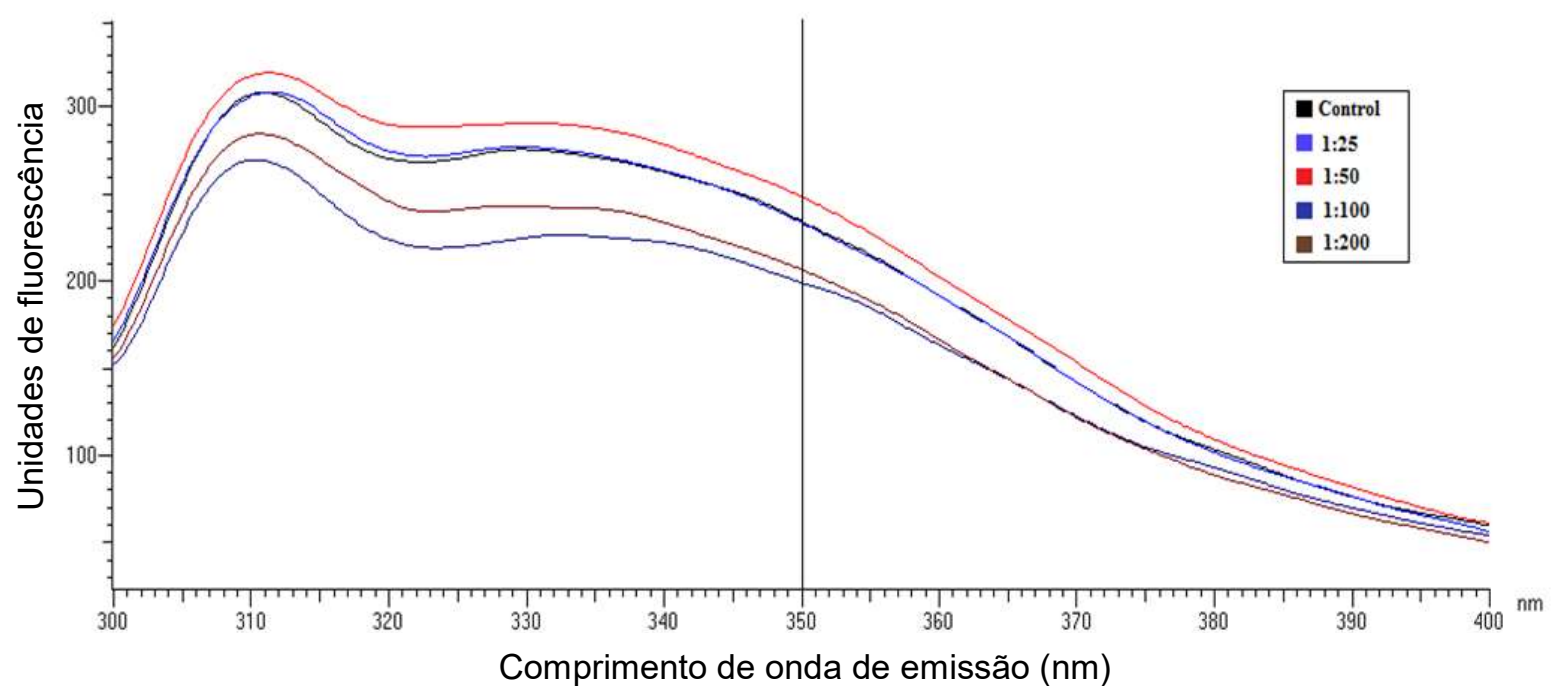

FIGURA 35 - Espectro de emissão $(300-400 \mathrm{~nm})$ dos complexos de papaína e ciclodextrina em diferentes proporções molares após solubilização dos compostos $(\mathrm{T}=0)$.

A interação da papaína e da ciclodextrina em função do tempo foi avaliada visando estabelecer o tempo de incubação a ser adotado para a realização da síntese do complexo, permitindo uma avaliação da influência deste parâmetro na formação do complexo.

Após 24 horas de incubação, os espectros de fluorescência (FIGURA 36) indicaram que existe, para todas as concentrações de $\beta-C D$, um aumento significativo da intensidade de fluorescência se comparada a papaína nativa, fornecendo uma evidência da formação do complexo.

A utilização dos complexos nas proporções molares maiores (superiores à 50 $\eta \mathrm{Mol}$ ) de $\mathrm{CD}$ foram descartados, considerando a perda de atividade enzimática registrada nos experimentos utilizando o substrato específico. 


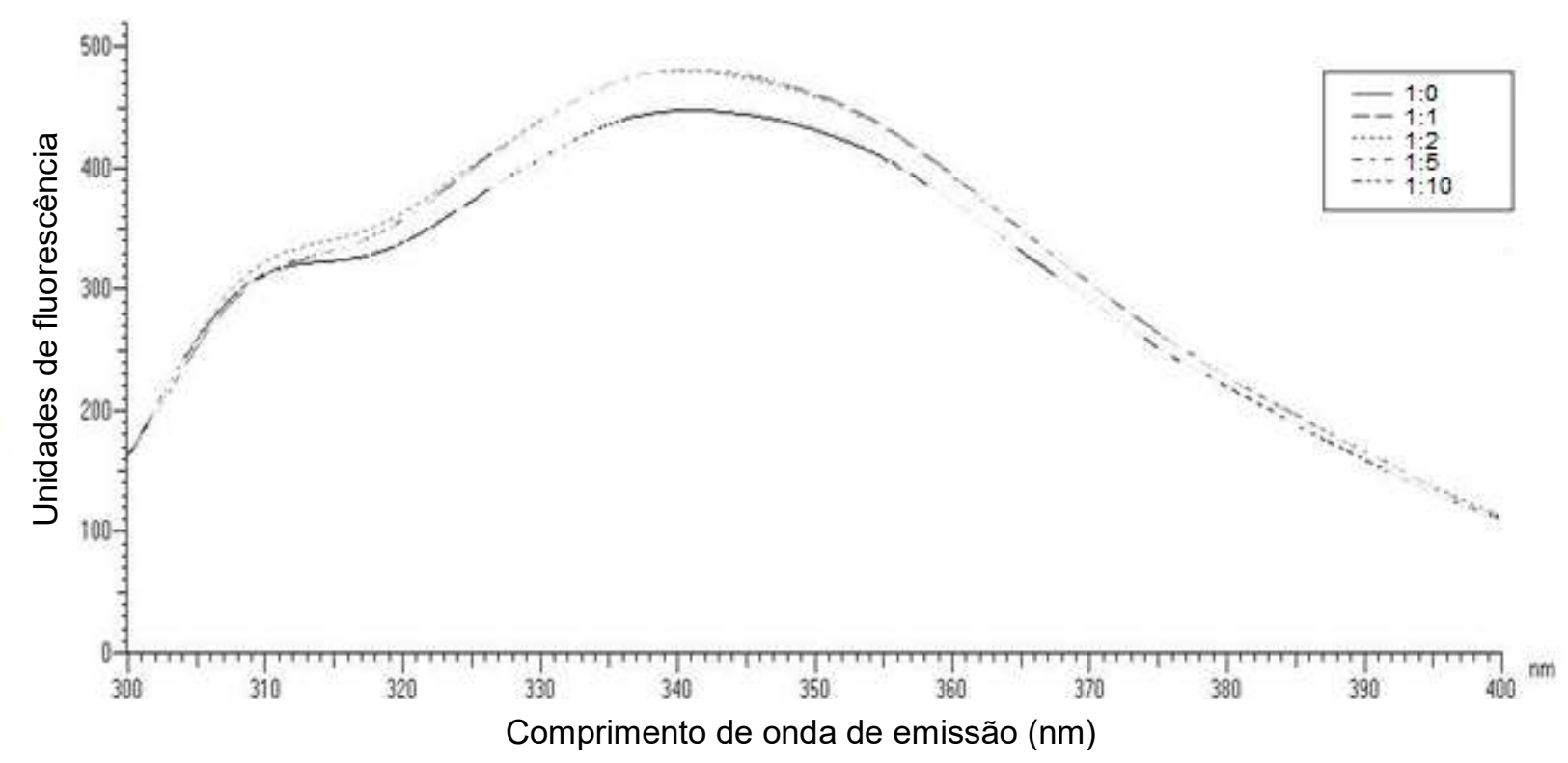

FIGURA 36 - Espectro de fluorescência da papaína e ciclodextrina após 24 horas de incubação.

A análise de bioatividade enzimática revelou decréscimo de atividade para todas as concentrações após 24 horas (FIGURA 37), com exceção da proporção molar de 1:10, que, embora tenha apresentados modificações nos perfis de fluorescência, não apresentou perda significativa da atividade enzimática.

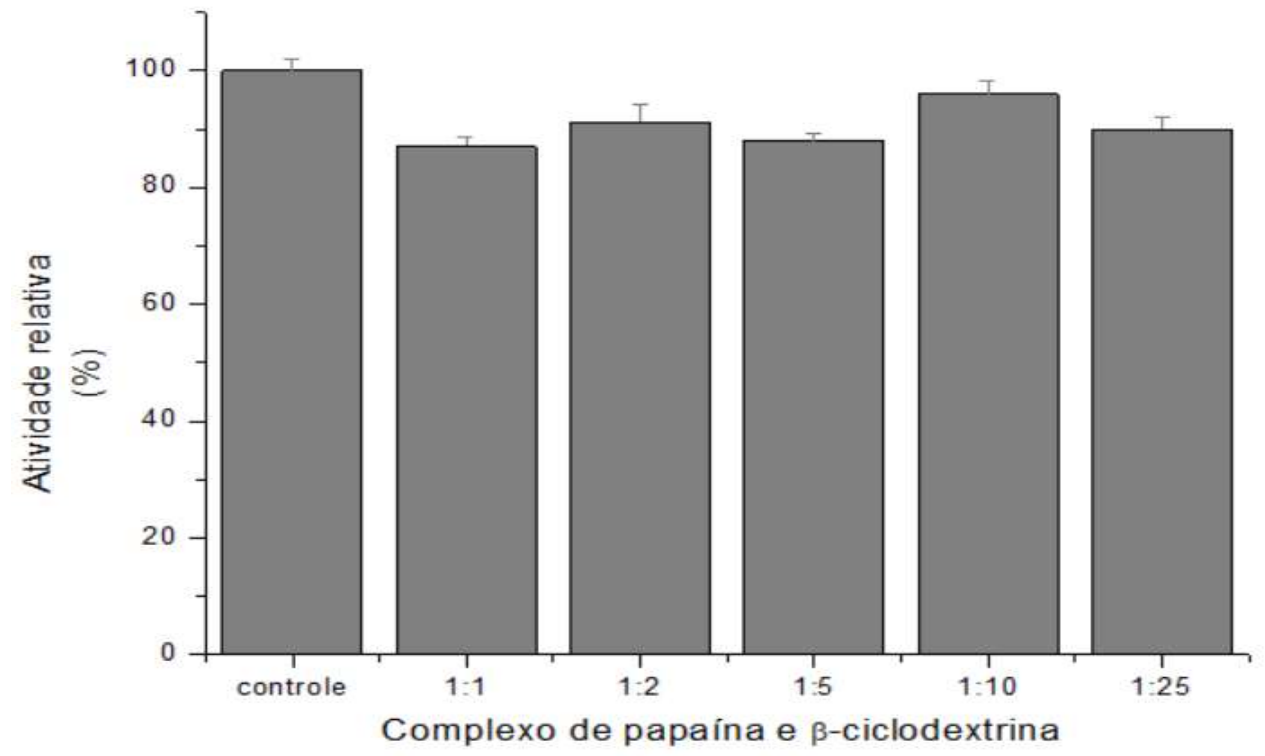

FIGURA 37 - Atividade enzimática dos complexos de papaína e $\beta$-ciclodextrina (1-25 $\eta$ १ol) após 24 horas de incubação. 
Decorridas 48 horas de incubação, a análise de fluorescência revelou que todos os complexos apresentaram diminuição da intensidade dos picos se comparados ao controle (FIGURA 38). Cabe ressaltar que a sensibilidade à hidrólise da enzima [8] aumenta de acordo com a exposição por longos períodos de incubação.

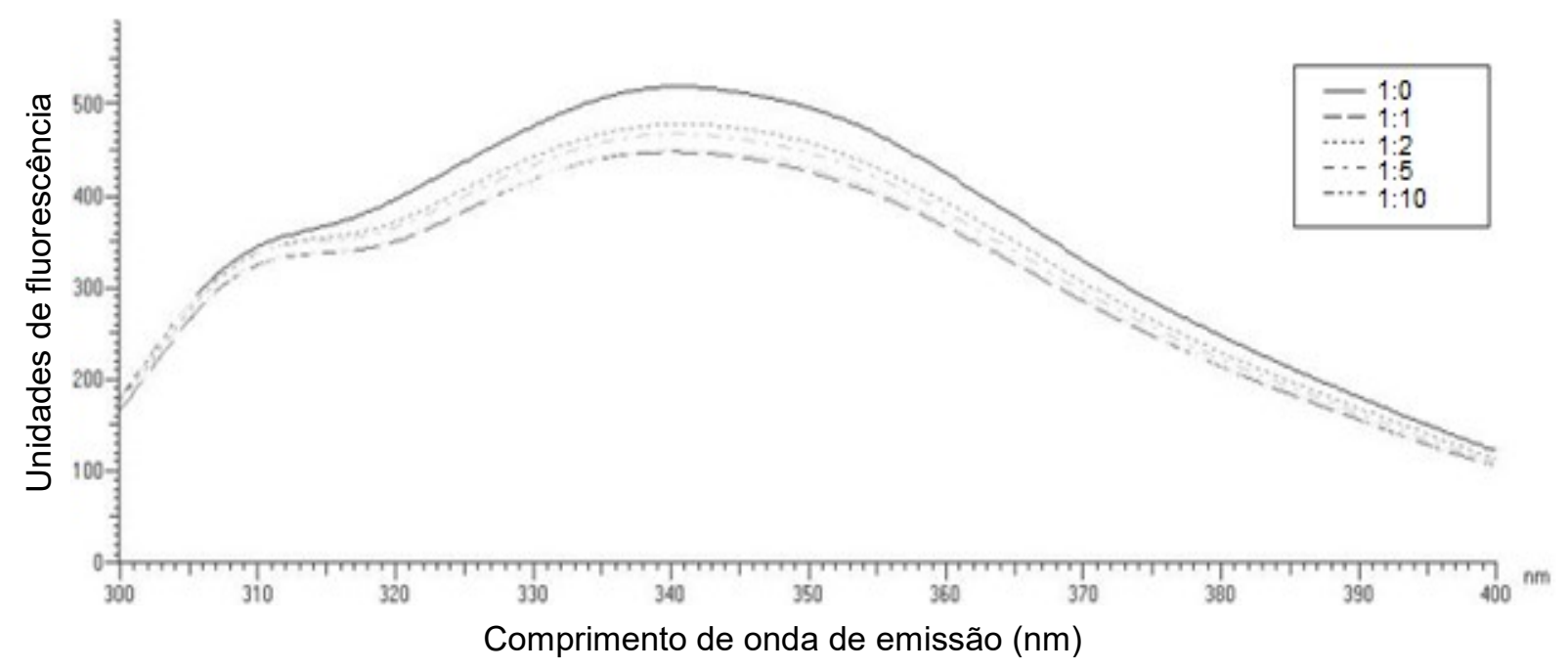

FIGURA 38 - Espectro de fluorescência de complexo de papaína e ciclodextrina em diferentes proporções molares no tempo de 48 horas.

Destaca-se que a proporção molar de 1:10 apresenta, novamente, modificações mais significativas em relação às demais amostras.

Com estes experimentos, foi possível selecionar a concentração de 1:10 como possível proporção molar adequada para a formação do complexo, embora caracterizações ainda sejam necessárias para confirmar tal escolha. O tempo de incubação selecionado foi de 24 horas, considerando que, nas decorridas 48 horas, o espectro de fluorescência indicou possível desestabilização da estrutura proteica e maior queda na bioatividade da enzima, corroborando os resultados obtidos.

A estequiometria dos complexos de ciclodextrina envolvem proporções molares de 1:1, 1:2; contudo, nestes casos o encapsulamento ocorre com praticamente a molécula toda, e, como resultado, observam-se modificações intensas nas propriedades físico-químicas do material como resultado deste fenômeno. No caso das proteínas, como os complexos são múltiplos, a localização exata destes 
complexos pode ou não assegurar modificações significativas na molécula encapsulada, resultando em alterações menos pronunciadas frente a complexos típicos.

As ciclodextrinas não complexadas presentes no meio contribuem para a manutenção da conformação original da proteína, favorecendo sua estabilidade e, em alguns casos, assegurando manutenção da estabilidade enzimática. Os resultados obtidos sugerem alterações mais significativas na faixa de 5-10 ฤMol, e deste modo, selecionamos a proporção molar de 1:10 (PAP: $\beta C D$ ) para a formação do complexo, considerando também os resultados computacionais.

Embora os resultados tenham evidenciado modificações mais significativas com uso de proporções molares superiores ao selecionado, o fator limitante que inviabiliza a utilização de concentrações mais elevadas de ciclodextrina corresponde à solubilidade destes oligossacarídeos [97,98], impossibilitando a execução dos processos em maior escala, além do efeito desestabilizante sobre proteínas.

\subsubsection{OTIMIZACÃO DO COMPLEXO DE PAPAINA E CICLODEXTRINA}

A influência do uso de diferentes ciclodextrinas e da trealose, açúcar não cíclico reconhecido por melhorar a estabilidade da papaína [12], na fluorescência da papaína em função do tempo foi avaliada.

Ao compararmos os espectros de fluorescência da papaína utilizando $\beta$ :CDs modificadas com 24 horas de incubação (FIGURA 39), um perfil distinto indica diferentes respostas frente ao uso de diferentes ciclodextrinas, onde as alterações mais significativas foram observadas para $\beta-C D$, ocasionando um aumento de fluorescência. $O$ complexo obtido com HP- $\beta C D$ se mostrou similar ao controle, e utilizando $D M-\beta C D$, uma redução na intensidade foi observada. $A$ trealose revelou um perfil similar ao da $D M-\beta C D$, porém com maiores alterações. 


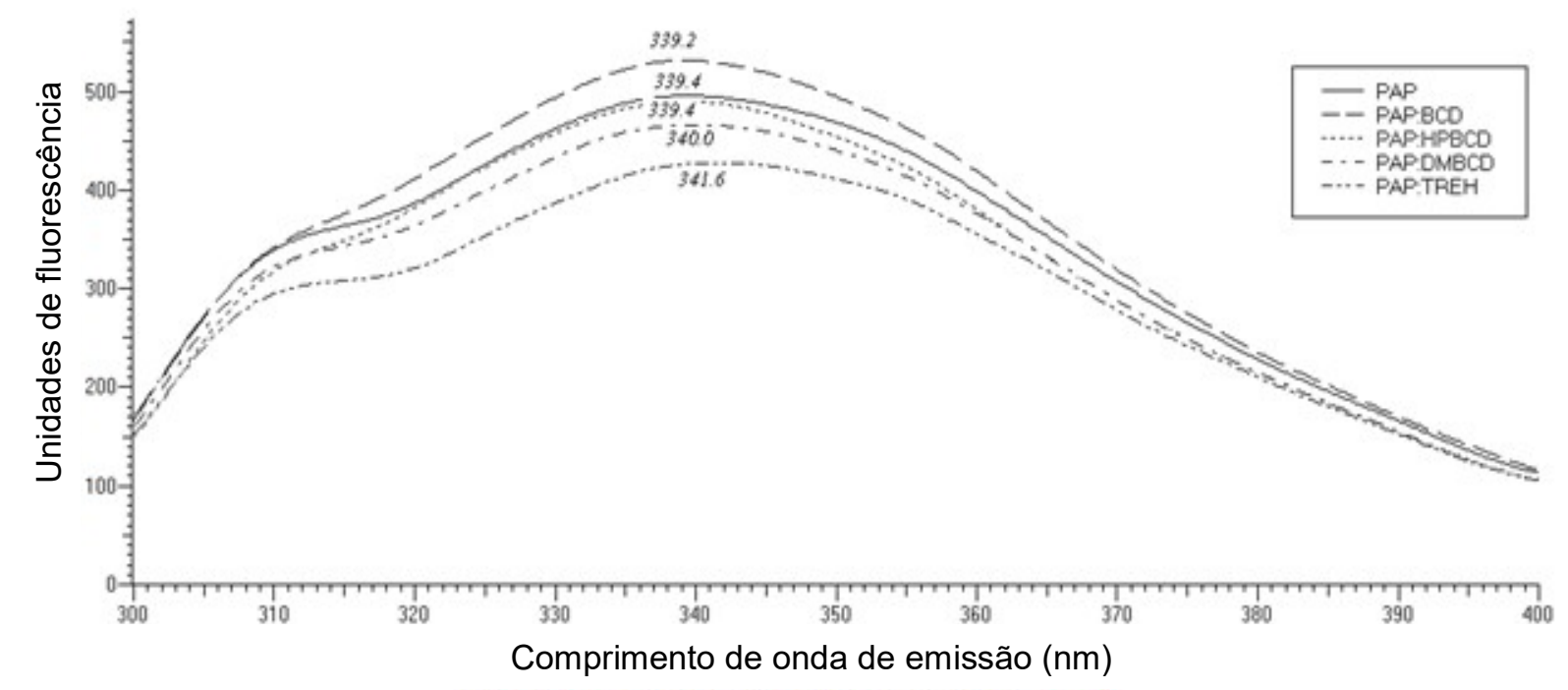

FIGURA 39 - Espectros de fluorescência dos complexos de papaína e diferentes ciclodextrinas após 24 horas de incubação.

As modificações apresentaram uma tendência a se tornarem mais significativas em função do tempo, contudo o período não foi estendido, uma vez que se estipulou o tempo de encapsulamento molecular de 24 horas, considerando perda de atividade característica da enzima em soluções aquosas.

Considerando que a alteração no perfil da enzima é diferenciada frente ao tipo de ciclodextrina utilizada, ressalta-se a necessidade de avaliar os resultados da caracterização biológica para ver qual delas é mais eficaz para atender às necessidades propostas no trabalho.

\subsubsection{SÍNTESE DO COMPLEXO DE PAPAÍNA E CICLODEXTRINA}

A síntese do complexo de papaína e $\beta-C D$ foi realizada utilizando os parâmetros determinados, como proporção molar de 1:10, 24 horas de incubação e agitação de $90 \mathrm{rpm}$. O processo de liofilização durou em torno de 3 a 4 dias, levando a formação de um pó altamente higroscópico. O rendimento do processo está em torno de $90 \%$. 
Após terminado o processo, o complexo desenvolvido foi embalado, selado à vácuo e devidamente identificado. O produto foi armazenado em freezer $\left(-20^{\circ} \mathrm{C}\right)$ até o momento do uso. O produto desenvolvido em uma embalagem própria está representado na FIGURA 40.
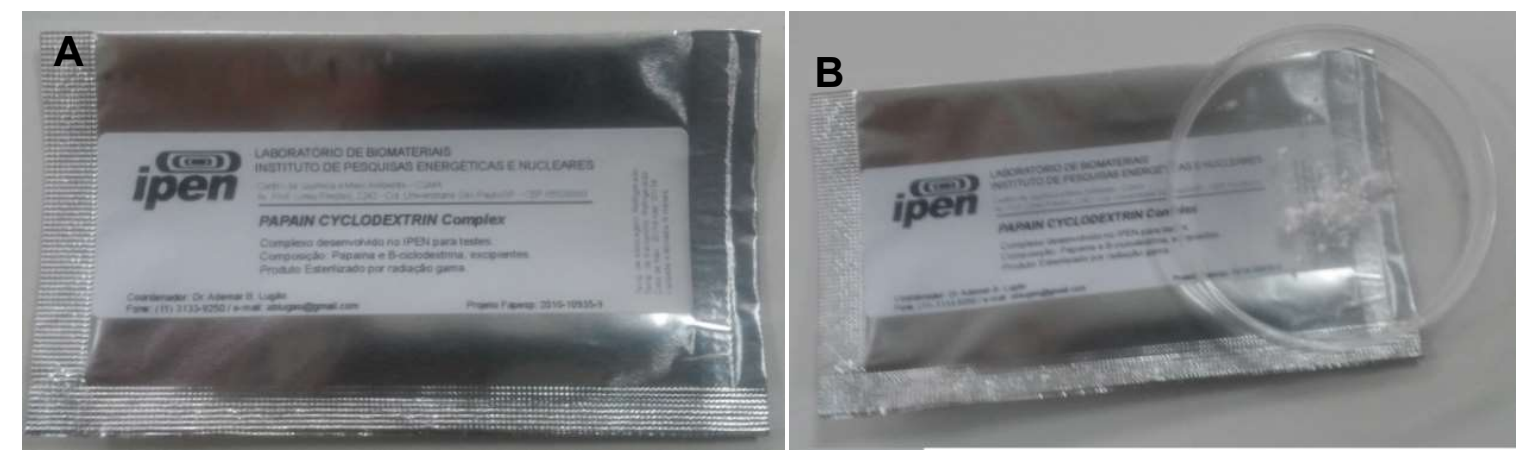

FIGURA 40 - Complexo de papaína e $\beta$-CD desenvolvido, considerando que: A embalagem contendo $1 \mathrm{~g}$ do complexo; B - complexo liofilizado.

\subsubsection{CARACTERIZACAO BIOLÓGICA DO COMPLEXO}

\subsubsection{CITOTOXICIDADE}

\section{QUERATINÓCITOS HUMANOS}

A avaliação da citocompatibilidade do complexo foi inicialmente estudada utilizando queratinócitos humanos, uma vez que estas são as células alvo, por comporem a camada mais externa da pele [85]. A FIGURA 41 contém os resultados de viabilidade celular frente ao estímulo utilizando papaína nativa como controle e o complexo sintetizado em diferentes proporções molares. 


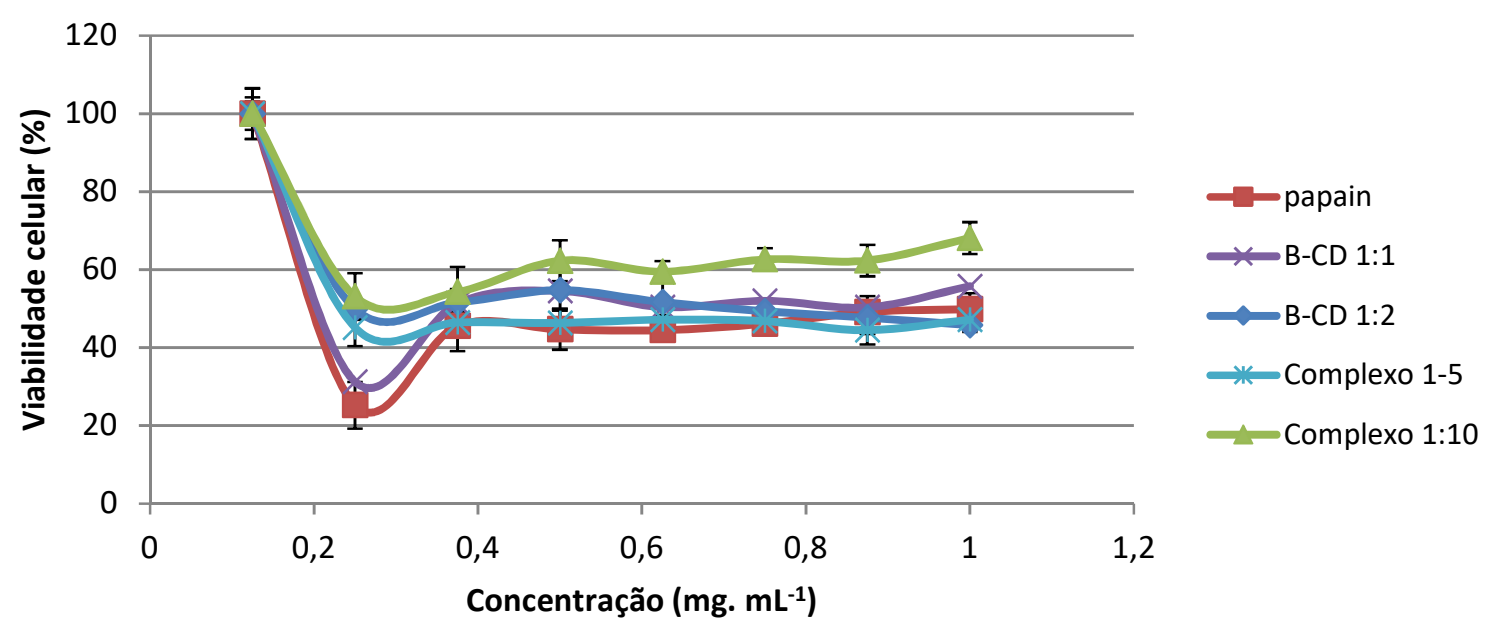

FIGURA 41 - Ensaio de viabilidade celular após contato da papaína e complexo em queratinócitos humanos, utilizando como corante vital o MTS.

A papaína nativa foi capaz de induzir a morte celular de maneira significativa em concentrações muito baixas, como inferiores a $0.2 \mathrm{mg} \cdot \mathrm{mL}^{-1}$. Estes dados corroboram a literatura, contudo, a enzima apresenta como característica uma ação semelhante à da tripsina (trypsin-like activity) [84], conhecida como efeito "detachment", causando o descolamento das células.

Deste modo, a toxicidade gerada parece estar mais relacionada com um impedimento da adesão celular e, portanto, impedindo a célula de desempenhar suas funções vitais. Por esta mesma razão, não se observa um efeito dose-dependente, porém, após atingir a concentração necessária para promover o descolamento, não há uma influência direta na perda de viabilidade em função do aumento da concentração de papaína, conforme observado na FIGURA 41.

A seleção da faixa de concentração para estudo da citotoxicidade da papaína foi fundamentada em estudos anteriores, que já apontaram essa faixa de concentração como tóxica nessa linhagem celular [25], de modo a permitir a identificação de um possível efeito das ciclodextrinas sobre a citotoxicidade intrínseca da enzima.

O emprego da $\beta$-ciclodextrina levou a um aumento nos índices de viabilidade celular de maneira dose dependente, uma vez que os melhores índices de viabilidade foram atingidos para o complexo na proporção molar de 1:10, corroborando os 
ensaios físico-químicos e ensaios computacionais. Tal alteração foi limitada com relação a modificar a resposta de tóxica para não tóxica, porém foram observadas melhoras significativas na viabilidade celular em torno de $30 \%$. Tal efeito foi observado em todas as concentrações testadas e proporções molares.

Sumarizando os resultados obtidos, com relação ao perfil citotóxico, o emprego da $\beta-C D$ como ferramenta para diminuir a toxicidade da enzima se mostrou eficaz com redução na toxicidade característica da papaína, porém não suficiente para eliminar o caráter citotóxico da enzima.

PBMC

De modo a determinar se a citotoxicidade observada de fato correspondia a ação citotóxica da enzima ou era apenas decorrente de efeitos sobre a adesão celular, células com propriedades distintas aos queratinócitos foram selecionadas. Para tanto, o ensaio de viabilidade celular foi realizado em PBMC. Estas células têm contato secundário com a lesão, e mesmo não correspondendo às células-alvo, elas possuem papel fundamental na resposta imune, além de não serem aderentes como os queratinócitos, o que permite uma avaliação precisa do efeito citotóxico da enzima sem influência do efeito sobre a adesão celular.

Decorridas 24 horas do estímulo com papaína (FIGURA 42), as concentrações foram viáveis até a concentração de $0,8 \mathrm{mg} \cdot \mathrm{mL}^{-1}$, considerando o material como citocompatível com índices de viabilidade celular superiores a $80 \%$. 


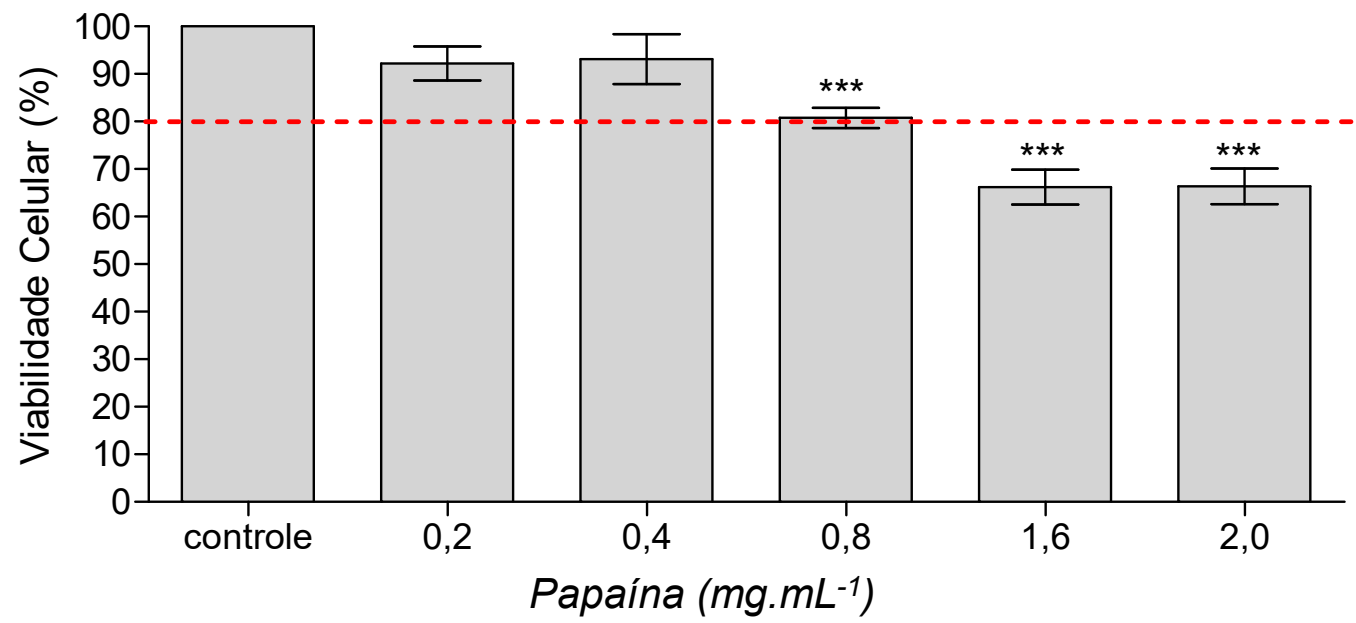

FIGURA 42 - Avaliação da citotoxicidade da papaína em PBMC após 24 horas de contato.

Após 72 horas de estímulo, apenas as concentrações de 0,2 e $0,4 \mathrm{mg} \cdot \mathrm{mL}^{-1}$ se mostraram citocompatíveis, enquanto as amostras em concentração igual ou superior a $0,8 \mathrm{mg} \cdot \mathrm{mL}^{-1}$ se mostraram citotóxicas (FIGURA 43). Esta informação permite identificar que existem ao menos dois parâmetros que influenciam na citotoxicidade da papaína, a concentração e o tempo, indicando que concentrações superiores podem ser seguras, desde que sejam utilizadas por um tempo reduzido.

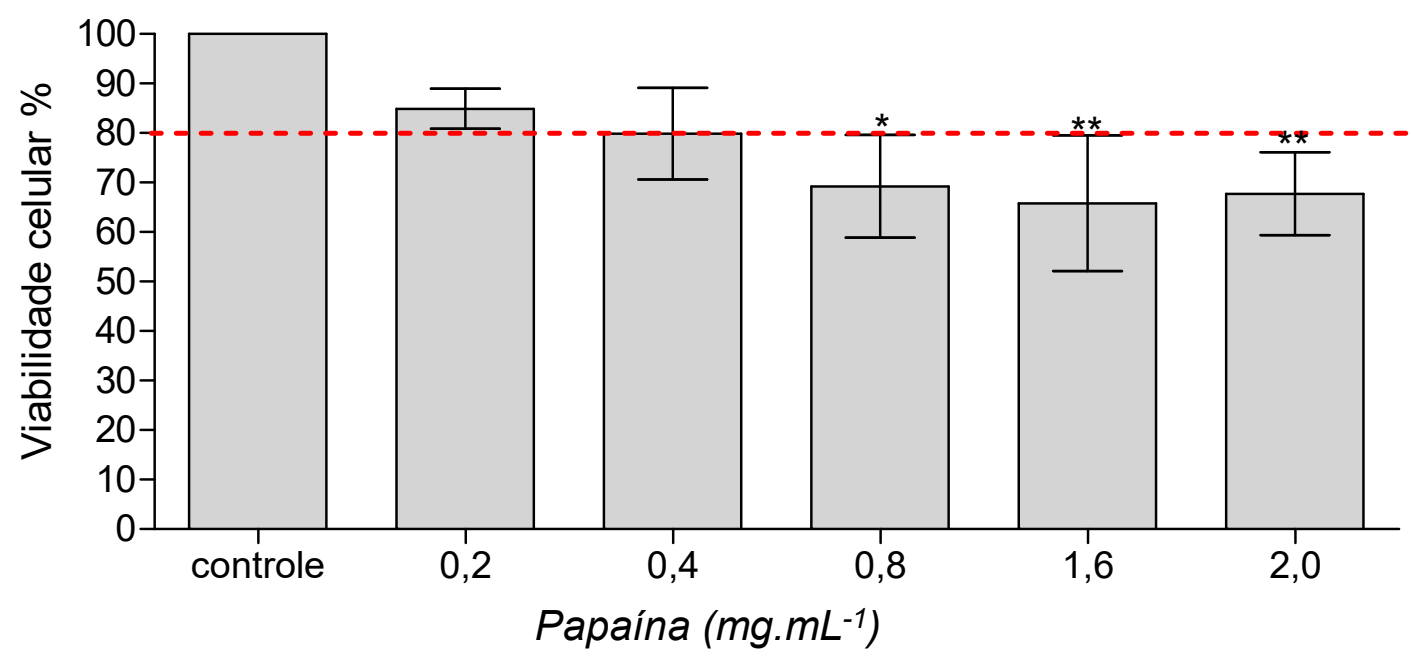

FIGURA 43 - Avaliação da citotoxicidade da papaína em PBMC após 72 horas de contato. 
Ao compararmos os resultados obtidos do estímulo de papaína frente aos queratinócitos com os resultados do PBMC, é possível distinguir um efeito citotóxico real observado no PBMC em relação ao efeito da adesão celular da papaína, evidenciado nos queratinócitos humanos.

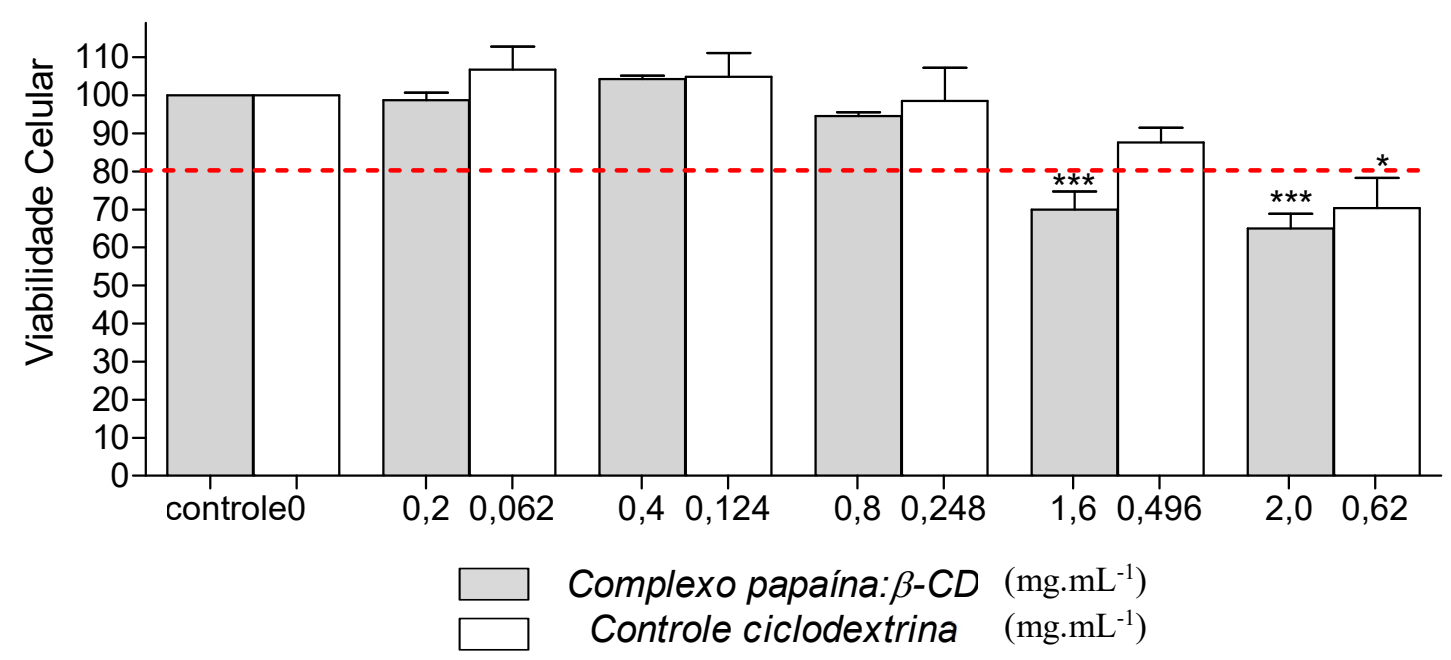

FIGURA 44 - Avaliação da citotoxicidade da papaína complexada com $B-C D$ em PBMC após 24 horas de contato.

Na presença do complexo na proporção molar de 1:10, a resposta celular foi ligeiramente distinta (FIGURA 44) decorridas 24 horas de contato, evidenciando um possível efeito citoprotetor, uma vez que os índices de viabilidade sofrem mudanças mínimas até a concentração de $0,8 \mathrm{mg} \cdot \mathrm{mL}^{-1}$.

Após 72 horas, tal efeito é ainda mais evidente, conforme observado na FIGURA 45. Os complexos não se mostraram mais citotóxicos e, de maneira semelhante ao efeito de 24 horas de estímulo, as concentrações viáveis foram estabelecidas como $0,8 \mathrm{mg} \cdot \mathrm{mL}^{-1}$. Tal efeito não foi observado para os queratinócitos humanos, considerando que a papaína já era citotóxica em concentrações muito mais baixas. 


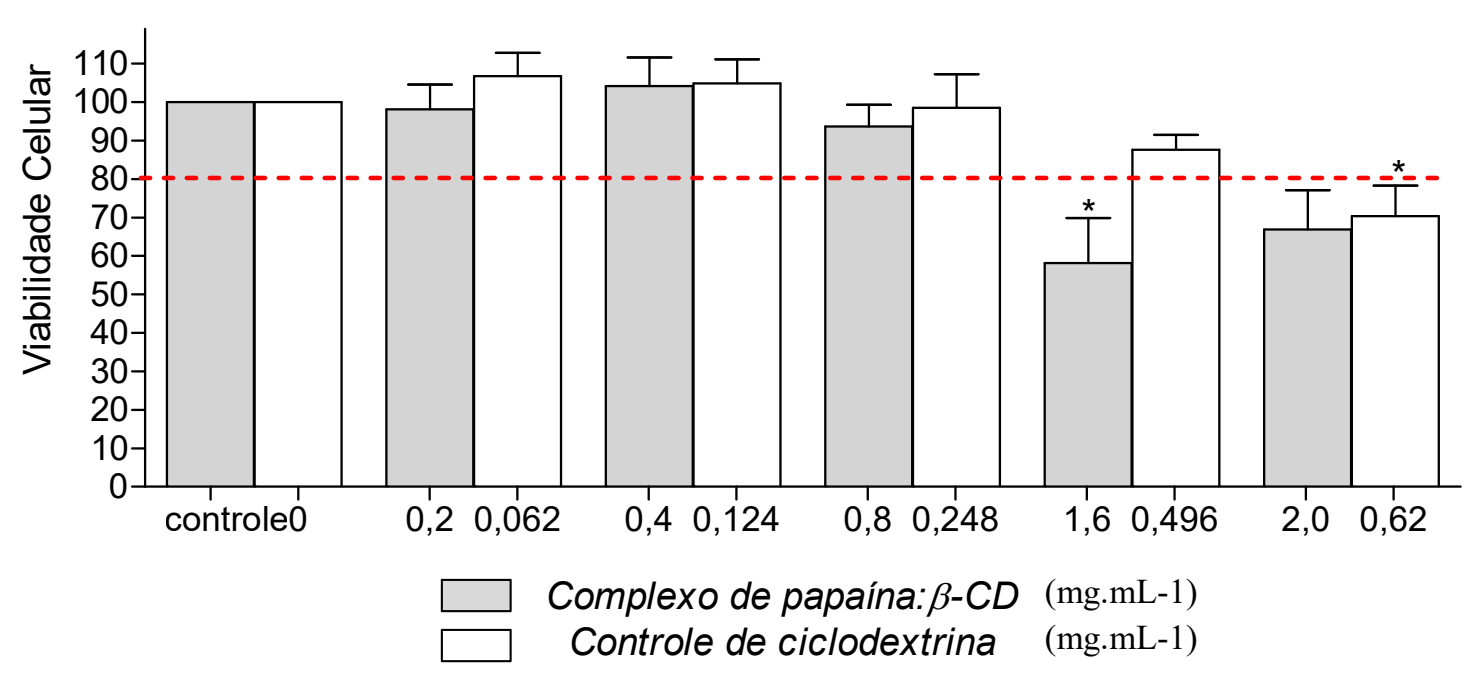

FIGURA 45 - Avaliação da citotoxicidade da papaína em PBMC após 72 horas de contato.

Considerando tais informações, é possível verificar que o efeito da formação do complexo acarreta melhora nos perfis de viabilidade celular, tornando possível o emprego da papaína no tratamento de feridas, seja visando debridamento ou cicatrização, com redução das reações adversas decorrentes do emprego da enzima isolada.

\subsubsection{AVALIÇÃO DO POTENCIAL INFLAMATÓRIO E IMUNOGÊNICO}

\section{LIGAÇÃO ANTÍGENO-ANTICORPO}

A avaliação de possíveis modificações na resposta imune desencadeada pela papaína foi realizada por meio de ensaios de ELISA, utilizando anticorpo policlonal específico obtido de cabra, com o objetivo de identificar possíveis modificações causadas pela irradiação e/ ou pela formação dos complexos com ciclodextrina.

A técnica selecionada permite detectar e determinar a ligação de anticorpos frente a um antígeno, além de fornecer dados quantitativos sobre a ligação. À natureza policlonal do anticorpo, ela assegura múltiplos epítopos de ligação com o antígeno e, desta forma, é adequada para monitorar as possíveis modificações na ligação da enzima com seu anticorpo específico frente à modificação realizada. 
Na FIGURA 46 observa-se perfil equivalente estatisticamente para a papaína livre e irradiada, e redução significativa da ligação com o anticorpo na presença da ciclodextrina.

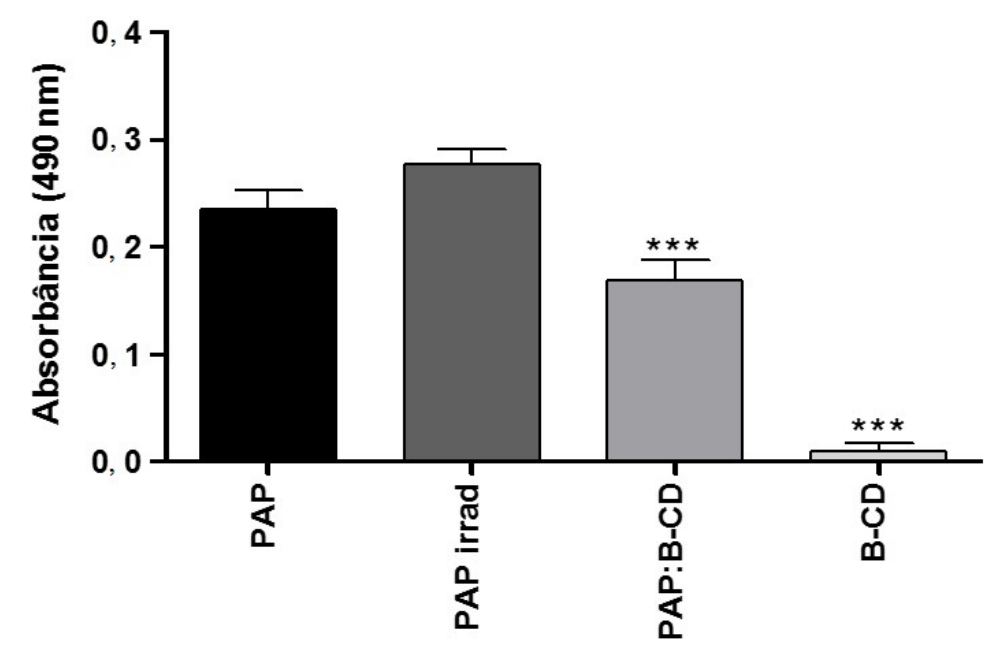

FIGURA 46 - Interação papaína-anticorpo por método de ELISA da papaína nativa, irradiada (10 kGy) e complexo de papaína e B-CD. ${ }^{* * *}=p<0,0001$.

De maneira mais específica, a irradiação da papaína, na dose estabelecida de 10 kGy, não desencadeou alteração ou modificação estrutural capaz de perturbar ou mascarar os sítios de ligação da enzima com o anticorpo específico (FIGURA 46), indicando que ao contrário do reportado na literatura para outros derivados proteicos [17], possivelmente, no caso da papaína, não seriam observadas diferenças na resposta imunológica frente à exposição do anticorpo ante à papaína irradiada e nativa.

Com relação ao emprego da ciclodextrina, os resultados evidenciaram o potencial de redução na resposta imunológica induzida pela papaína quando complexada com ciclodextrina, se comparada à proteína nativa; e, embora tal resultado seja limitado com relação a indicar e revelar possíveis efeitos de supressão na resposta imune, o mesmo consiste em evidência experimental de possível diminuição das reações imunológicas desencadeadas. É relevante destacar que as ciclodextrinas isoladas não apresentaram leitura significativa (controle negativo) e, 
deste modo, confirma a ausência de possível interferência deste componente no ensaio.

Dada a evolução na tecnologia das ciclodextrinas, a $\beta$-ciclodextrina, alvo do estudo, apresenta diversas modificações em seus radicais, incluindo grupamentos metil, dimetil, hidroxipropil e outras, a fim de melhorar as características deste oligossacarídeo cíclico, como solubilidade, hidrofobicidade, dentre outras. Deste modo, visando otimizar possíveis efeitos da complexação utilizando $\beta$-ciclodextrinas modificadas, o ensaio foi realizado empregando m- $\beta: C D, d m-\beta: C D$ e $h p-\beta: C D$.

Ao compararmos os perfis de ligação antígeno-anticorpo, observamos que as ciclodextrinas modificadas apresentam um efeito adicional sobre os sítios de ligação da papaína se comparadas à complexação utilizando $\beta$-ciclodextrina, revelados pelo decréscimo de intensidade na interação papaína-anticorpo para os complexos obtidos a partir de diferentes ciclodextrinas (FIGURA 47), onde se destaca um perfil de ligação decrescente na ordem de $B C D>M B C D>D M \geq H P$ respectivamente. Novamente as ciclodextrinas isoladas não apresentaram intensidade de ligação significativa com o anticorpo, excluindo possível interferência nos resultados.

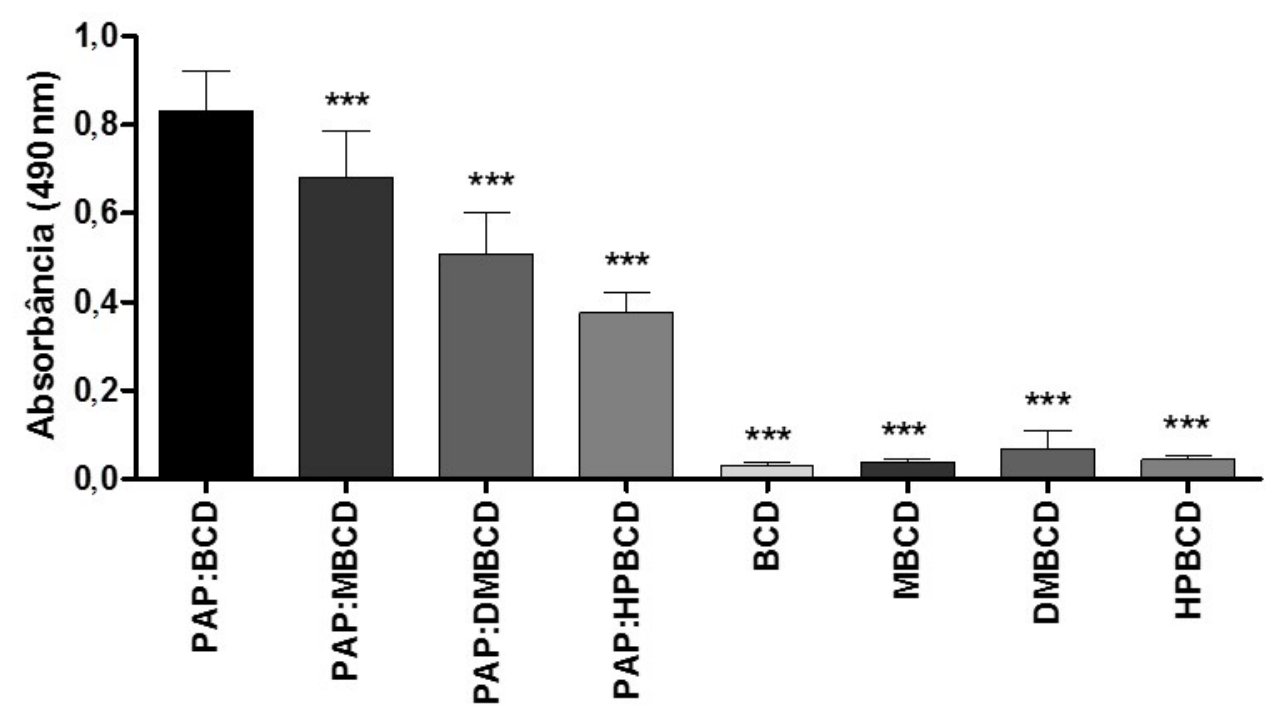

FIGURA 47 - Avaliação da ligação papaína-anticorpo por método de ELISA dos complexos de papaína e diferentes ciclodextrinas. ${ }^{* * *}=p<0,0001$. 
Estas informações fornecem evidências experimentais de que o emprego de tais ciclodextrinas poderia, eventualmente, reduzir ainda mais as possíveis respostas imunológicas desencadeadas pela papaína se comparadas a $\beta: C D$, embora o experimento realizado não permita identificação do motivo para tal modificação, seja por motivos de impedimento estérico ou por diferenças de polaridade.

$O$ emprego de tais $\beta: C D$ s modificadas, entretanto, não promove apenas benefícios com relação ao encapsulamento molecular utilizando $\beta$-ciclodextrina, uma vez que existem limitações atribuídas ao custo elevado [97], e à toxicidade em algumas vias de administração. De maneira mais específica, as ciclodextrinas metiladas ou lipofílicas são indicadas para uso oral, enquanto a hidroxipropil é útil para administração parenteral $[97,98,99]$.

A $\beta-C D$, embora apresente limites de solubilidade, permite um emprego de seus complexos, do ponto de vista farmacêutico, pelas vias oral e tópica, sendo em geral bem tolerado e empregado em medicamentos comercialmente disponíveis. No entanto, seu emprego via parenteral é restrito, justamente devido à sua baixa solubilidade [98].

As ciclodextrinas hidrofilicas, como a $h p: \beta-C D$, são bem toleradas via oral e intravenosa, em concentrações de baixas a moderadas. Em contrapartida, as ciclodextrinas mais lipofílicas, como a metil ou dm: $\beta-C D$, são amplamente absorvidas pelo trato gastrintestinal e são tóxicas para uso parenteral. Seu emprego por via oral é possível, porém restrito pela toxicidade [98,99].

\section{DOSAGEM DE CITOCINAS}

Partindo da premissa de possível supressão, ou ainda, de uma modificação nas propriedades de ligação antígeno-anticorpo, conforme observado experimentalmente, fez-se necessária a avaliação de possíveis mediadores envolvidos na resposta imunológica frente ao estímulo com a papaína livre e complexada. Para tal avaliação foi realizado o estímulo de esplenócitos murinos com as amostras, com posterior dosagem dos níveis de citocinas produzidos. 
A IL2 é uma interleucina essencial para o desenvolvimento e função regulatória das células $\mathrm{T}$, que desempenham o papel de inibir resposta imune e prevenir doenças autoimunes [100]. De maneira mais específica, a IL-2 promove a diferenciação de células $T$ em células $T$ efetoras e células $T$ de memória; quando estimulada por antígenos, tais interleucinas desempenham papel no combate a infecções, podendo também contribuir para supressão de doenças como a dermatite alérgica crônica [101].

A FIGURA 48 contém a dosagem de IL2 produzida a partir do estímulo com as amostras. Destaca-se um perfil mais pronunciado para a papaína irradiada e o complexo, evidenciando que tais modificações foram capazes de estimular a produção desta interleucina de maneira muito superior à enzima nativa, em nas concentrações mais baixas. Em concentrações maiores tal produção foi suprimida para todas as amostras avaliadas.

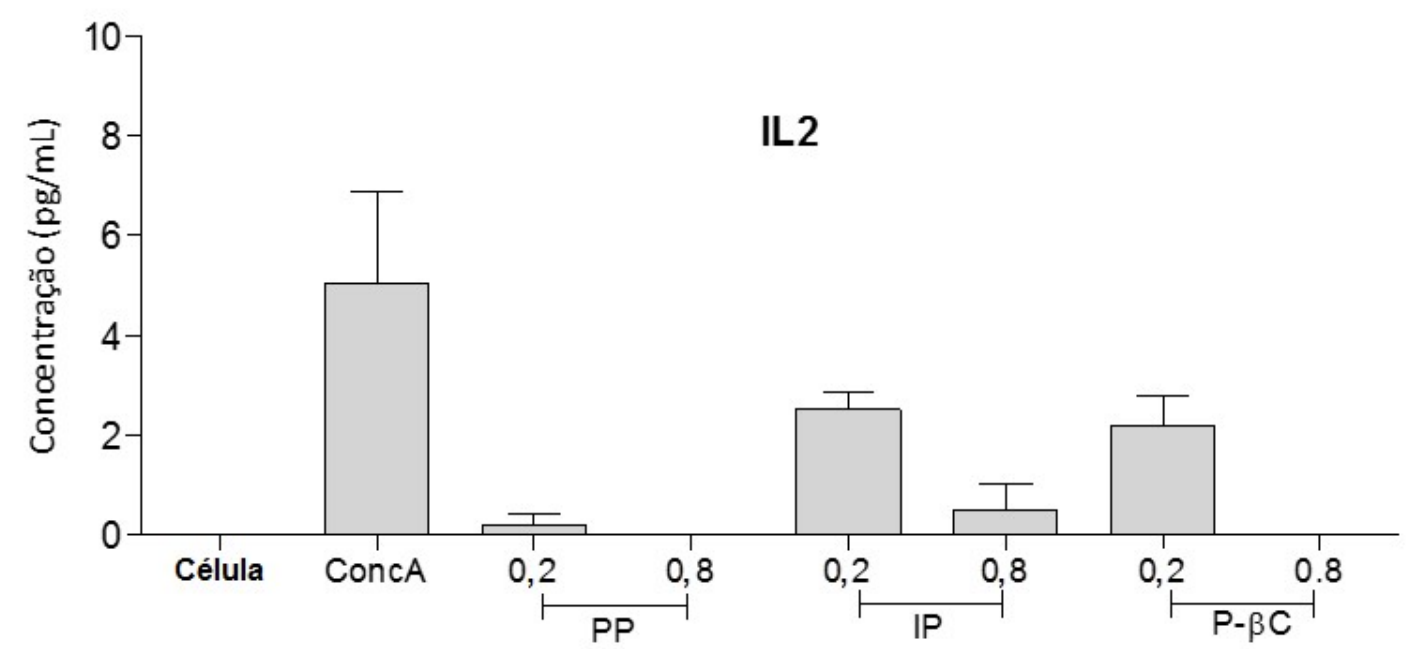

FIGURA 48 - Dosagens de IL2 produzidas por esplenócitos murinos expostos à papaína pura (PP), papaína irradiada (IP) e o complexo de papaína e $\beta$-ciclodextrina $(P-\beta C)$, realizada por citometria de fluxo usando o kit CBA.

O doseamento de IL6 (FIGURA 49) revelou que a produção desta interleucina ocorre de maneira basal, e tendo sido observadas diferenças pouco significativas frente ao estímulo com papaína nativa e complexada, se comparadas à produção basal. O estímulo com papaína irradiada levou a um leve aumento em tais níveis. 
A IL6 é uma citocina pró-inflamatória e altos níveis desta substância indicariam a presença de um processo inflamatório [102]. Desta forma, as alterações nos níveis de IL6 foram consideradas não significativas, com possível leve resposta próinflamatória indesejável, quando a enzima é irradiada.

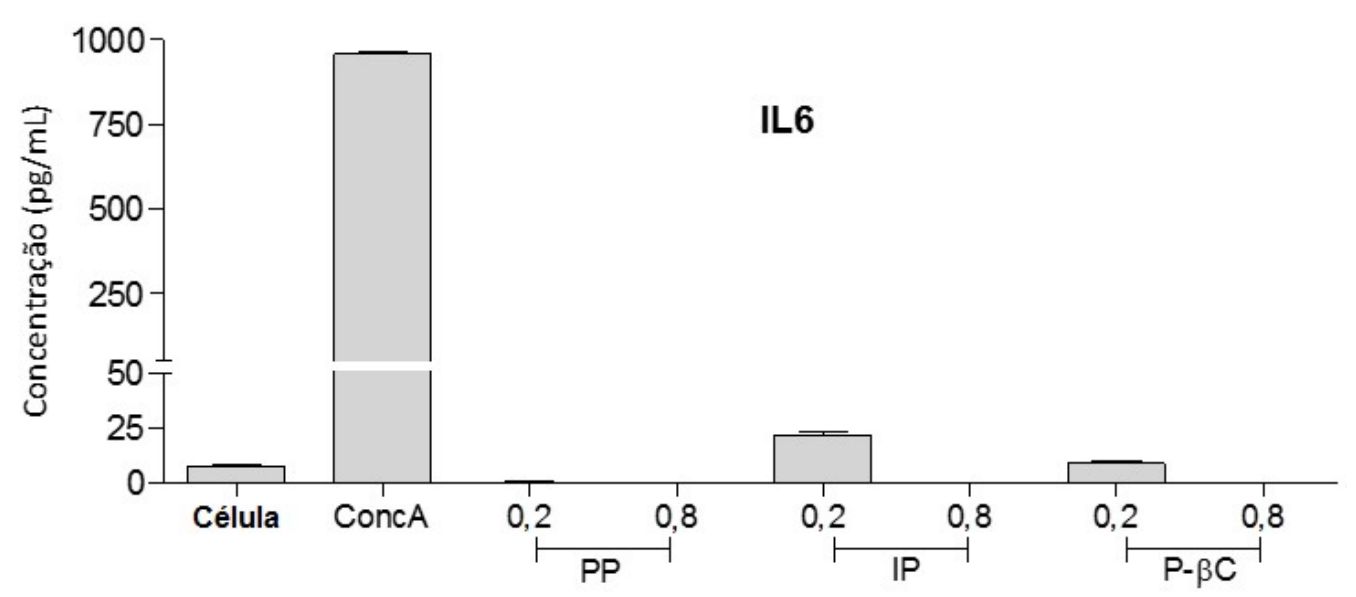

FIGURA 49 - Dosagens de IL6 produzidas por esplenócitos murinos expostos à papaína pura (PP), papaína irradiada (IP) e o complexo de papaína e $\beta$-ciclodextrina $(P-\beta C)$, realizada por citometria de fluxo usando o kit CBA.

Com relação a produção de IFNy (FIGURA 50), novamente, observa-se uma produção basal; após estímulos com as amostras, observa-se um efeito mínimo sobre os níveis celulares de IFNy, identificados por um leve aumento. Esta alteração foi menos significativa para o complexo. Contudo, os resultados observados são semelhantes quando comparados com alguns alérgenos quanto aos níveis de interferon local.

A importância desse interferon é que ele é um fator de ativação de macrófago, sendo a principal citocina efetiva da resposta imune celular, mostrando-se crucial para resolução de imunopatologias relacionadas à alergias [103]. Adicionalmente, essa citocina pode ser eficaz na redução da inflamação, e eosinofilia em dermatite severa alérgica [104]. 


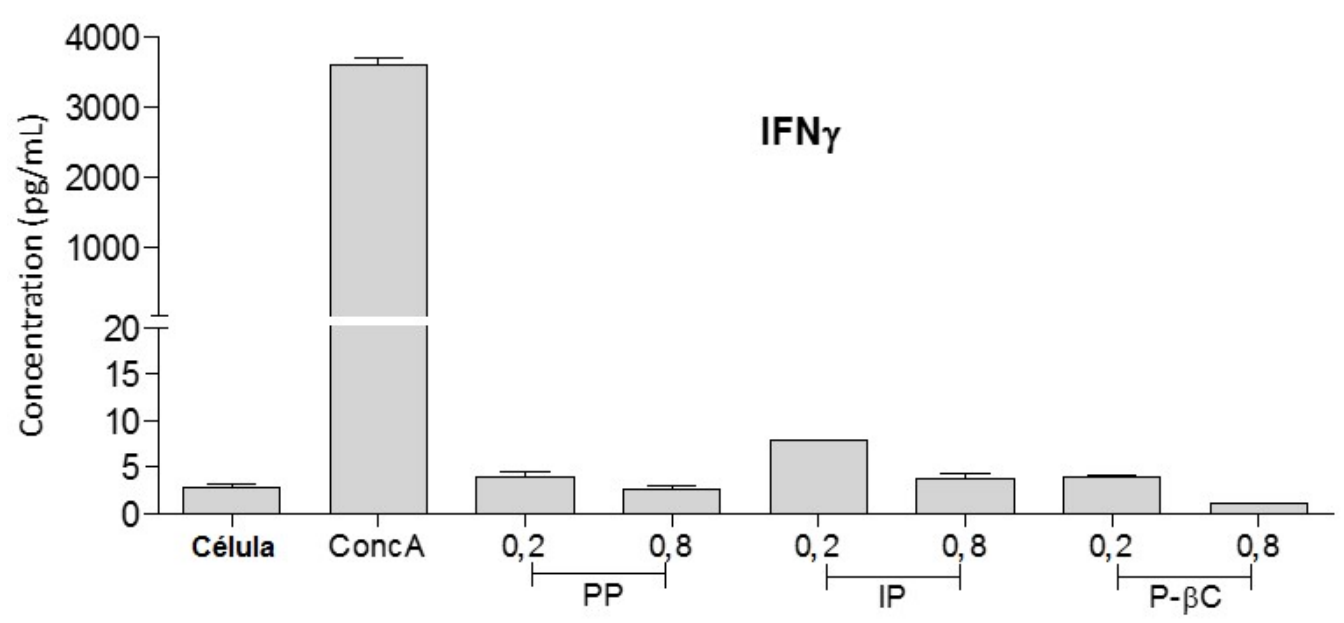

FIGURA 50 - Dosagens de IFNy produzidas por esplenócitos murinos expostos à papaína pura (PP), papaína irradiada (IP) e o complexo de papaína e $\beta$-ciclodextrina $(P-\beta C)$, realizada por citometria de fluxo usando o kit CBA.

Os níveis de TNFa não foram alterados em função dos estímulos realizados (FIGURA 51), excluindo possível relação desta citocina com a resposta imune desencadeada pela enzima. A não ativação deste fator é particularmente desejável, uma vez que esta citocina é altamente inflamatória [105].

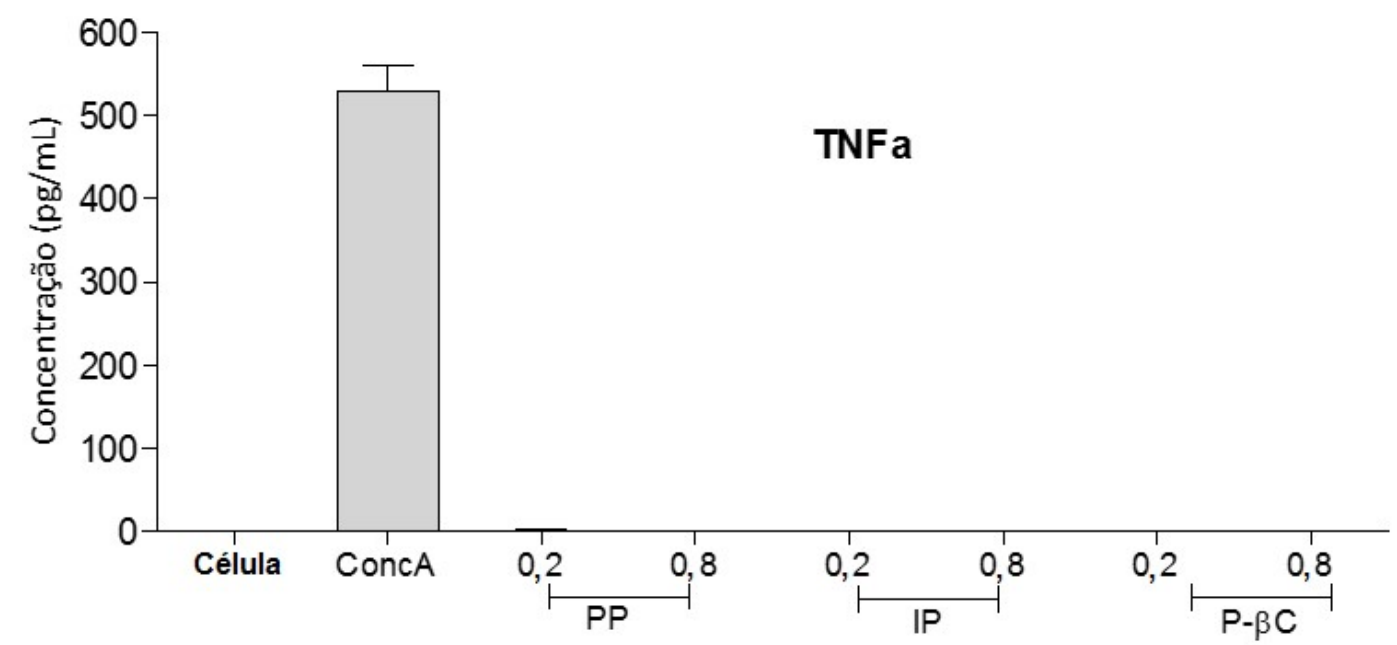

FIGURA 51 - Dosagens de TNFa produzidas por esplenócitos murinos expostos à papaína pura (PP), papaína irradiada (IP) e o complexo de papaína e $\beta$-ciclodextrina $(P-\beta C)$, realizada por citometria de fluxo usando o kit CBA. 
O mesmo perfil foi observado para IL17a (FIGURA 52) indicando que esta interleucina não participa da resposta do organismo frente à reação alérgica causada pela papaína. Esta interleucina apresenta importante ação pró-inflamatória e está associada a produção de IL6 [106].

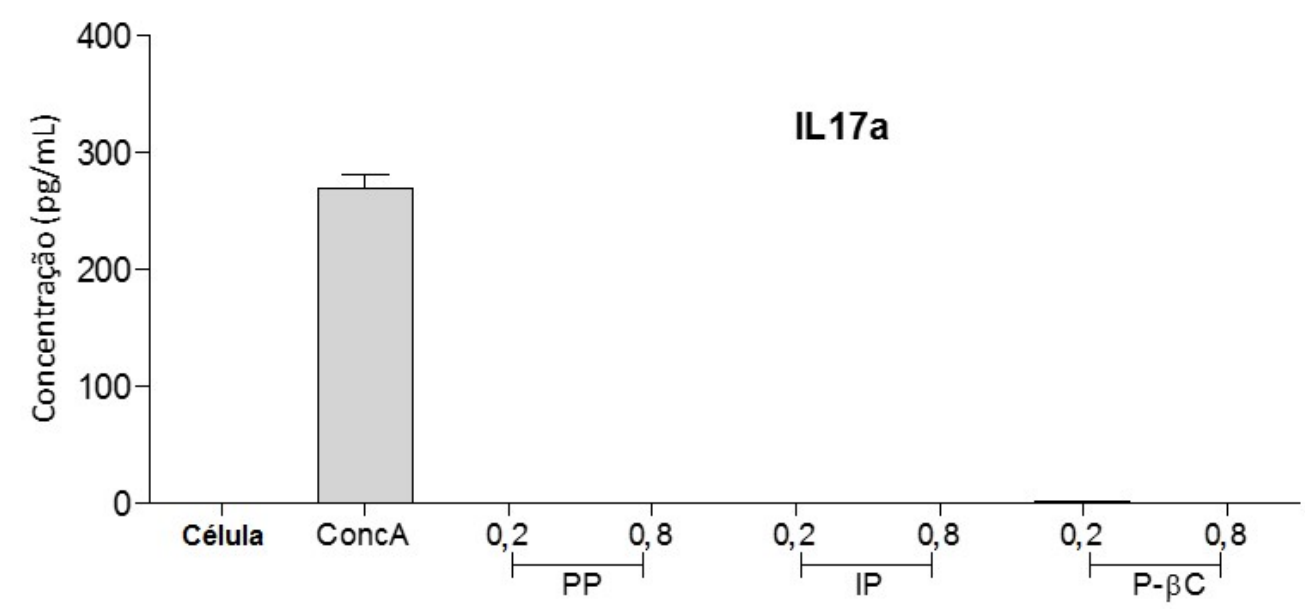

FIGURA 52 - Dosagem de IL 17a produzidas por esplenócitos murinos expostos à papaína pura (PP), papaína irradiada (IP) e o complexo de papaína e $\beta$-ciclodextrina $(P-\beta C)$, realizada por citometria de fluxo usando o kit CBA.

Os perfis de IL4 (FIGURA 53) também não sofreram alteração frente aos estímulos. Esta informação é relevante, considerando que uma produção exacerbada de IL-4 está diretamente associada a alergias, enquanto a ausência de produção desta citocina evidencia que as formulações testadas não são potencialmente alergênicas [107]. De maneira específica, a Interleucina-4 é uma citocinas que desempenha papel crucial na regulação de resposta imune, sendo capaz de causar supressão dos macrófagos e estimular produção de imunoglobulinas [107]. 


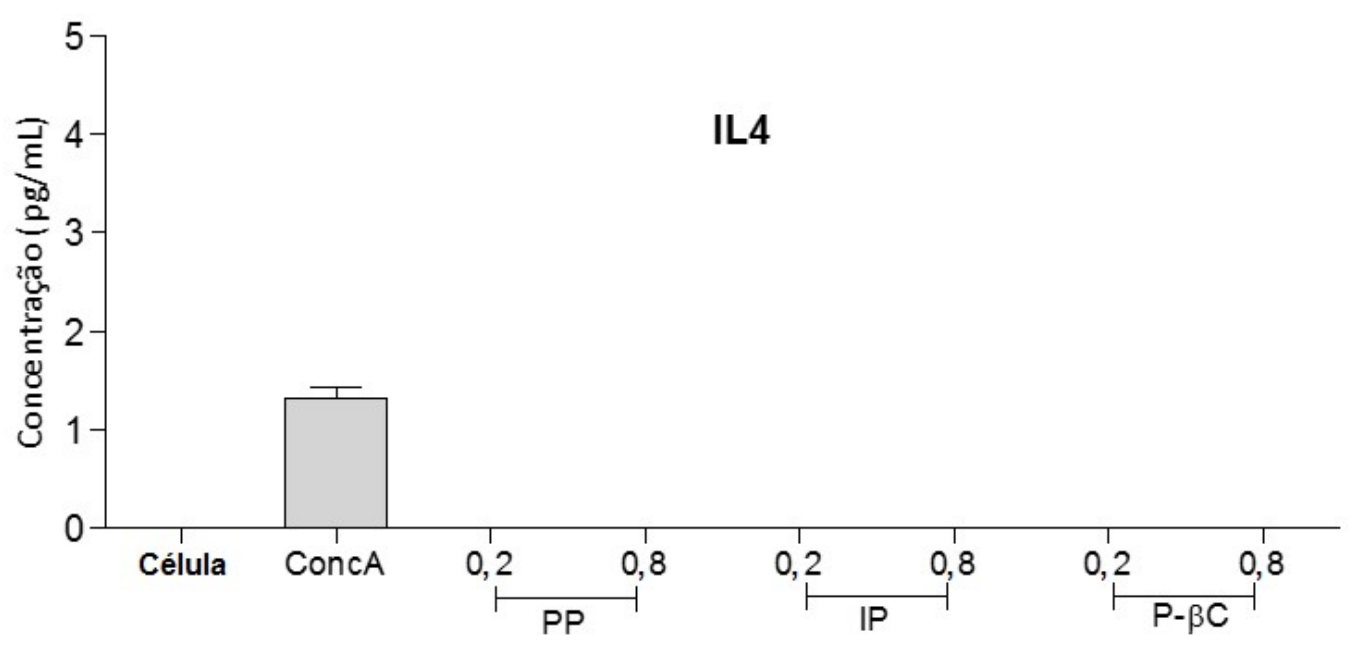

FIGURA 53 - Dosagens de IL4 produzidas por esplenócitos murinos expostos à papaína pura (PP), papaína irradiada (IP) e o complexo de papaína e $\beta$-ciclodextrina $(P-\beta C)$, realizada por citometria de fluxo usando o kit CBA.

A Il-10 é uma interleucina anti-inflamatória que modula inflamações promovidas por doenças alérgicas [108], e de maneira frequente, os níveis de IL10 são expressados em reações de natureza alérgica como asma, anafilaxia e alergia, regulando estas respostas mediadas por lgE, estando também relacionada com inflamação [109]. Embora a expressão desta interleucina esteja reduzida frente ao estímulo com papaína, papaína irradiada e o complexo (FIGURA 54), tal expressão é desejável, pois compõe resposta do sistema imune frente a reações alérgicas.

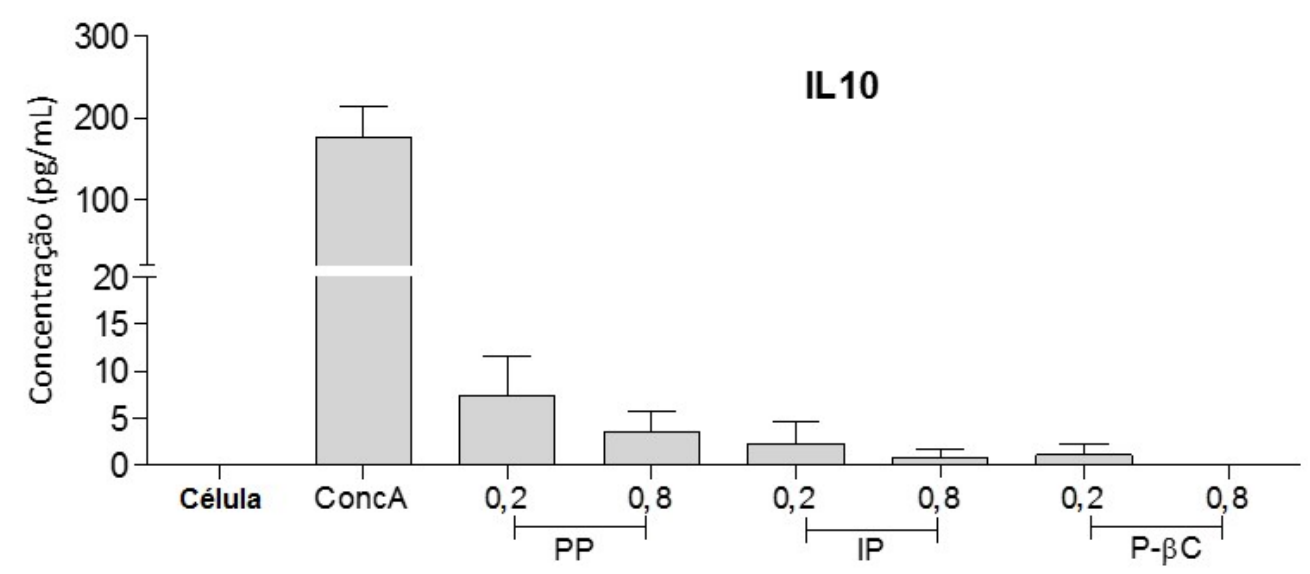

FIGURA 54 - Dosagens de IL10 produzidas por esplenócitos murinos expostos à papaína pura (PP), papaína irradiada (IP) e o complexo de papaína e $\beta$-ciclodextrina $(P-\beta C)$, realizada por citometria de fluxo usando o kit CBA. 
Em suma, o esplenócitos murinos apresentaram produção de citocinas pró e anti-inflamatórias frente ao estímulo com papaína, que aparentam estar em equilíbrio e a produção de IL10, que possivelmente corresponde a um dos principais mediadores da respostas imunogênicas induzidas pelo uso da papaína, se mostrou reduzida $\mathrm{O}$ emprego da radiação se mostrou pouco significativo sobre as citocinas envolvidas na inflamação, mas levou a redução significativa nos níveis de IL10, evidenciando possível supressão da reposta imune.

O complexo também foi capaz de alterar as citocinas relacionadas à inflamação, e de forma mais significativa se comparado à papaína pura e irradiada, ocasionou uma supressão da IL10, mais uma vez indicando possível redução nos efeitos indesejáveis. Os resultados indicaram ativação celular local, porém com ação balanceada entre IFNy e IL-10, sugerindo baixa ou nenhuma alergenicidade desencadeada pelas formulações.

Estes resultados corroboram os experimentos da capacidade de ligação da papaína com o anticorpo, onde foi observada menor capacidade de ligação do complexo com anticorpo específico e consequentemente, menor resposta imunológica.

\subsection{EFEITO DA IRRADIACÃO NA PAPAÍNA}

\subsubsection{EFEITOS DIRETOS DA IRRADIAÇÃO}

A irradiação da papaína em pó não acarretou perda de atividade biológica frente às doses de irradiação aplicadas (TABELA 15). Tal efeito se atribui a dois fatores: o primeiro relacionado à presença de dissulfito de sódio, potente agente antioxidante empregado no ajuste da atividade da enzima, que impede a oxidação da papaína; e o segundo, relacionado aos efeitos diretos da radiação, que, no caso da irradiação proteínas, são menos expressivos se comparados aos indiretos. 
TABELA 15 - Valores de atividade relativa (USP.U/mL) registrados em cada meio frente a dose de radiação especificada.

\begin{tabular}{ccccc}
\hline Amostra & $\mathbf{0 ~ k G y}$ & $\mathbf{5 ~ k G y}$ & $\mathbf{1 5 k G y}$ & $\mathbf{2 5}$ kGy \\
\hline $\begin{array}{c}\text { Pó } \\
\text { Solução }\end{array}$ & 240 & 240 & 240 & 240 \\
aquosa & 216,5 & 169,2 & 57,24 & 42,76 \\
$\begin{array}{c}\text { Tampão } \\
\text { fosfato }\end{array}$ & 283,1 & 258 & 243,5 & 233,8 \\
Gel & 255,12 & 241,5 & 226,1 & 201 \\
\hline
\end{tabular}

Em solução aquosa, a atividade enzimática da papaína sofreu alterações bruscas em função da dose, levando à inativação de quase 80 \% utilizando 15 kGy, corroborando a literatura. Tal fato é atribuído aos efeitos indiretos da irradiação, uma vez que, ao sofrer radiólise, a água libera radicais capazes de atacar a estrutura proteica e levar à inativação da papaína [68].

Visando confirmar tal teoria, a papaína foi irradiada em tampão fosfato contendo cisteína, um agente antioxidante natural, e observou-se que o decréscimo de atividade em função da dose de irradiação foi suprimido quase que na totalidade, confirmando a hipótese elaborada.

De modo a avaliar possíveis interferências das propriedades de difusão do meio, a papaína foi irradiada em gel, contendo a mesma concentração de cisteína da solução tampão. Novamente o decréscimo de atividade enzimática foi similar. A proteção conferida pelo gel e pelo tampão foram muito semelhantes, mesmo sob diferentes doses de radiação (0-25 kGy) e diferentes condições de difusão, confirmando, portanto, que os efeitos da exposição à radiação estão diretamente relacionados com os efeitos indiretos da irradiação. É importante destacar que a cisteína também é capaz de ativar a papaína e, por isso, os valores de atividade inicial estão maiores que os registrados para papaína em pó.

Visando à esterilização do complexo, estes resultados indicam a possibilidade de irradiação do complexo na forma sólida e posterior incorporação em condições assépticas a uma forma farmacêutica ou, ainda, permitindo aplicação direta, 
considerando o emprego do complexo como uma nova forma de apresentação da papaína.

\subsubsection{EFEITOS INDIRETOS DA RADIAÇÃO}

Considerando o papel dos efeitos indiretos da irradiação na atividade da papaína, um estudo específico da interação da papaína com os principais radicais oriundos da radiólise da água, $\mathrm{OH}^{\bullet} e e^{-} a q$ foi realizado.

\section{EFEITO DA OH•}

Para avaliar a interação da papaína com a $\mathrm{OH}^{\bullet}$ foi realizada uma varredura frente a cada pulso de radiação aplicado. $\mathrm{O}$ aduto papaína- $\mathrm{OH}^{\bullet}$ apresenta uma faixa máxima de absorbância entre 290 e 350 nm (FIGURA 55) e deste modo, a determinação da constante de reação foi realizada a $330 \mathrm{~nm}$.

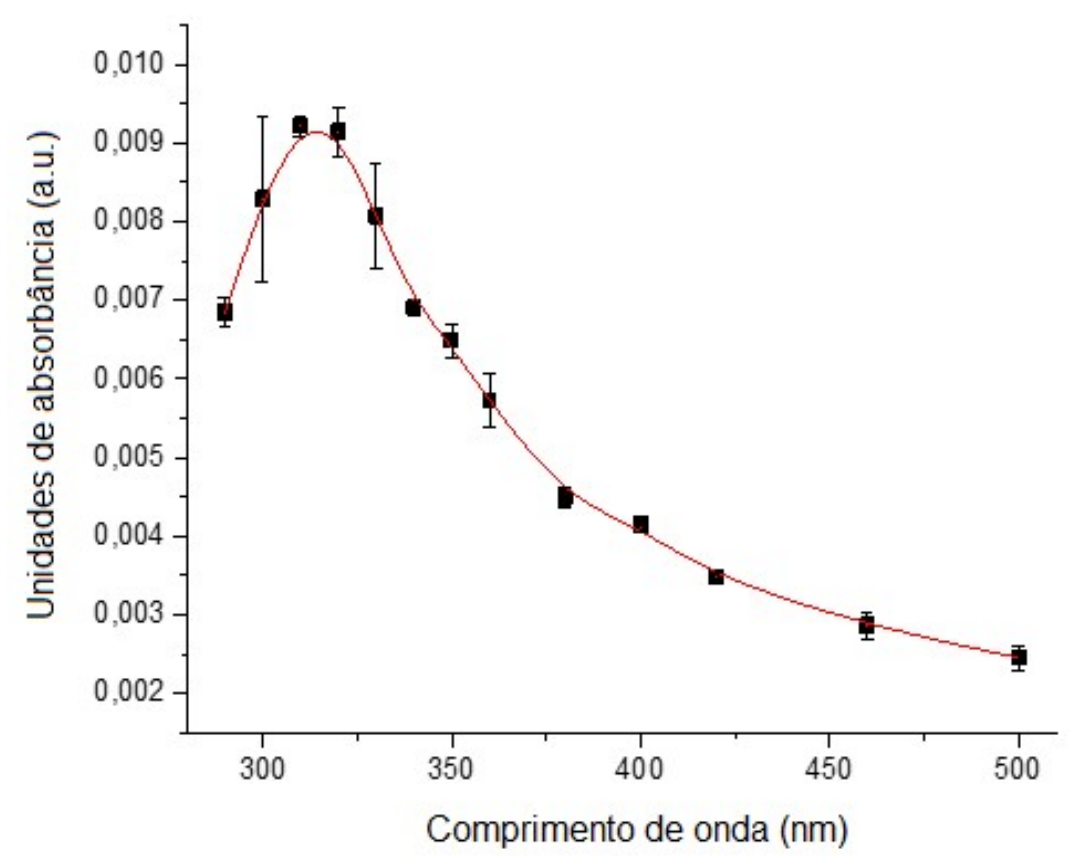

FIGURA 55 - Espectro de absorção no UV-Vis do aduto papaína-OH・ determinado por radiólise de pulso em atmosfera de $\mathrm{N}_{2} \mathrm{O}$. Pulso de $7 \mathrm{~ns}, 20$ Gy por pulso e $\lambda=290$ a $500 \mathrm{~nm}$. 
A cada pulso de radiação conferido, a formação e o decaimento do aduto foi foram acompanhados. A constante de reação, estabelecida como decaimento de cinética de primeira ordem ( $\left.k^{\prime}\right)$ dos radicais em função da concentração da enzima em uma escala de microssegundos (FIGURA 56).

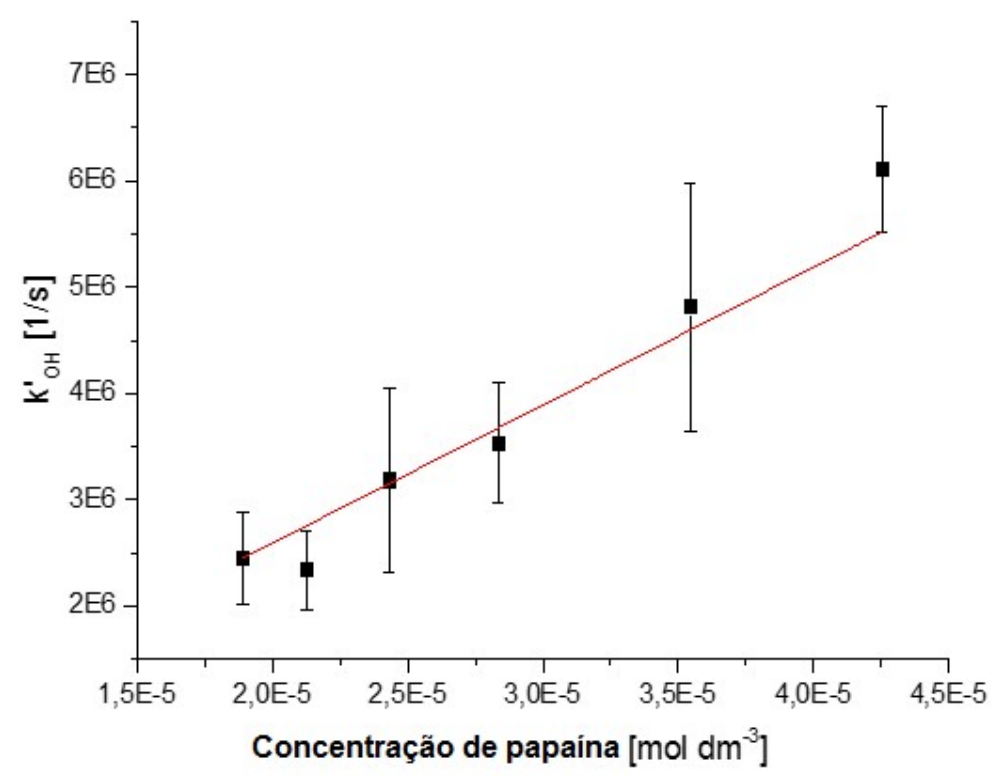

FIGURA 56 - Determinação da constante de reação do aduto papaína-OH ${ }^{\bullet}$ por radiólise de pulso em atmosfera de $\mathrm{N}_{2} \mathrm{O}$. Pulso de $7 \mathrm{~ns}, 20$ Gy por pulso e $\Lambda=330 \mathrm{~nm}$.

A constante de reação com $\mathrm{OH}^{\bullet}\left(\mathrm{kOH}^{\bullet}\right)$ com a papaína foi estabelecida como $1,3 \times 10^{11} \mathrm{dm}^{-3} \mathrm{~mol}^{-1} \mathrm{~s}^{-1}$. A literatura específica também descreve valores próximos aos obtidos, estabelecidos como $4,7 \times 10^{10} \mathrm{dm}^{-3} \mathrm{~mol}^{-1} \mathrm{~s}^{-1}[68,110]$. A discrepância obtida, possivelmente, consiste na diferença de purificação das papaínas utilizadas, já que a papaína utilizada neste trabalho corresponde ao grau de pureza bioquímico.

Os efeitos do $\mathrm{OH}^{\bullet}$ na molécula de papaína são capazes de desencadear a ativação da enzima, uma vez que o radical pode reagir diretamente com o resíduo cisteína-25, causando a oxidação do sítio ativo e, desta forma, inativando a enzima. Tais resultados evidenciam que embora a constante de reação com o $\mathrm{OH}^{\bullet}$ por resíduo seja baixa, a contribuição destes radicais para a inativação da enzima é relevante. 


\section{EFEITO DO E־AQ}

O elétron aquoso é uma molécula redutora, e seus efeitos na molécula da papaína são mais pronunciados sobre as pontes de dissulfeto, causando, assim, uma inativação irreversível da enzima [68].

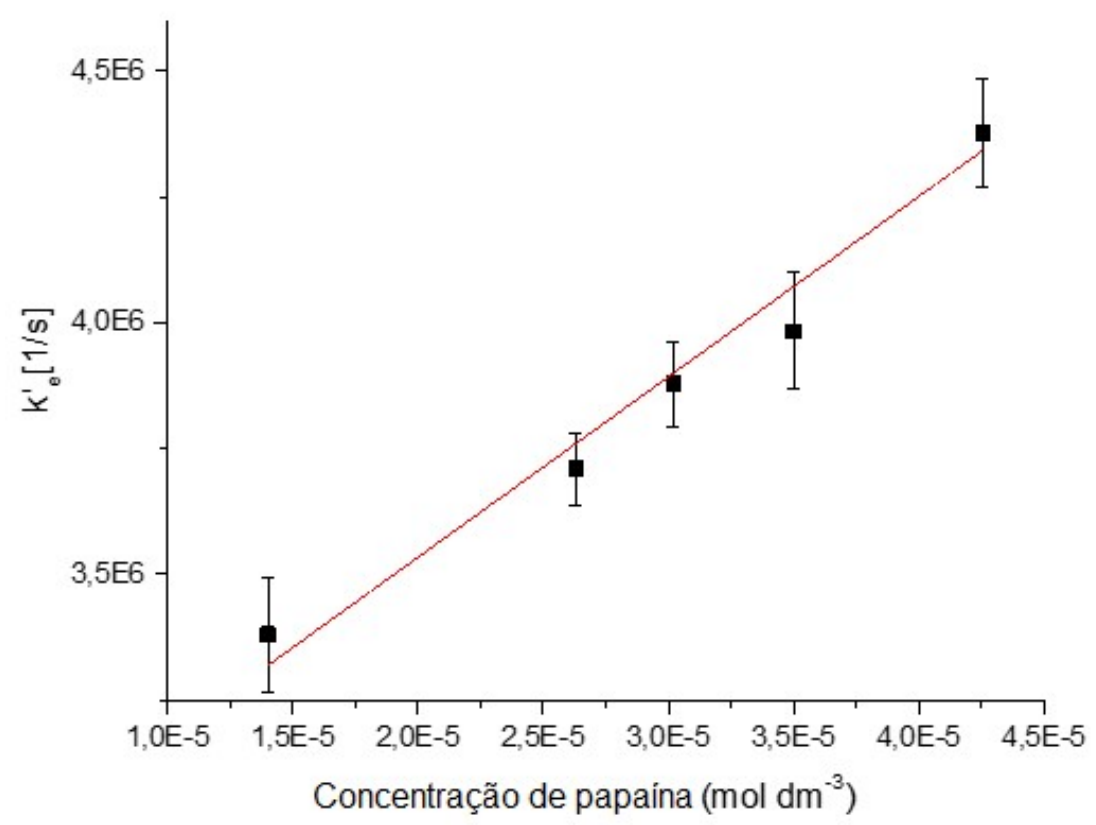

FIGURA 57 - Determinação da constante de reação do aduto papaína-e`aq. por radiólise de pulso. Pulso de $7 \mathrm{~ns}, 20$ Gy por pulso e $\Lambda=720 \mathrm{~nm}$.

A constante de reação da papaína com o $e^{-}$aq foi estabelecida como $1,44 \times 10^{6}$ para a molécula toda e 1,68 × $10^{5}$ para cada aminoácido (FIGURA 57), indicando contribuição de tal espécie reativa na degradação da enzima. No entanto, ao compararmos as constantes obtidas para o $\mathrm{e}^{-}$aq $\mathrm{e}^{\circ} \mathrm{OH}^{\bullet}$ respectivamente, observou-se que o elétron, embora exerça um efeito conhecido sobre a papaína, possivelmente não seja o principal responsável pela inativação da mesma, causada pela exposição à radiação, considerando os valores muito superiores obtidos para o $\mathrm{OH}^{\bullet}$. 


\subsection{DESENVOLVIMENTO DO HIDROGEL}

\subsubsection{HIDROGEL DE PVP}

Os hidrogéis à base de PVP apresentam translucidez característica e permite a visualização da ferida durante seu emprego como curativo (FIGURA 58), além de excelente biocompatibilidade, sendo, portanto, material de escolha para síntese de hidrogéis.

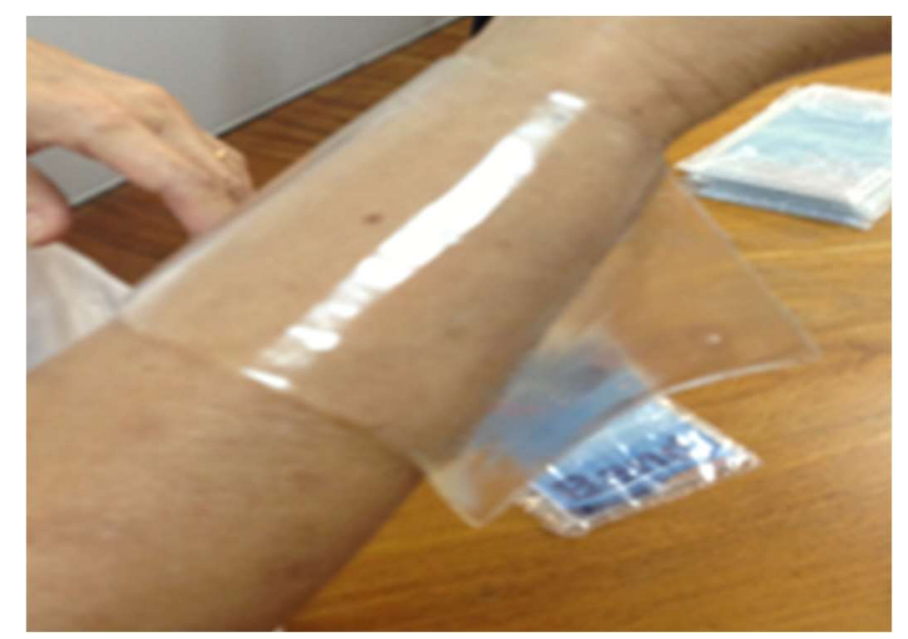

FIGURA 58 - Hidrogel de PVP desenvolvido.

As formulações protótipo utilizadas no estudo foram elaboradas considerando três compostos como base, o PVP, polímero a ser reticulado e formar a rede polimérica, o ágar, e o polietileno glicol. De maneira específica, o ágar foi empregado para permitir consistência mecânica adequada para as etapas de envase e exposição à radiação, e o polietileno glicol, para conferir plasticidade ao material.

Após a síntese do hidrogel, propriedades específicas dos sistemas foram avaliadas visando caracterização da forma farmacêutica, como integridade física (avaliação macroscópica), fração gel e intumescimento (TABELA 16).

Dentre os hidrogéis desenvolvidos, poucos apresentaram integridade física suficiente para aplicação como curativo. Dentre elas, as formulações mais adequadas 
para aplicação como curativo dérmico corresponderam as formulações $\mathrm{F}-2 \mathrm{~B}, \mathrm{~F}-2 \mathrm{C}$, F-2D, F-2E e F-2F.

TABELA 16 - Caracterização dos hidrogéis à base de PVP desenvolvidos.

\begin{tabular}{lcccccc}
\hline *Formulações & $\begin{array}{c}\text { PVP } \\
\text { (\%) }\end{array}$ & $\begin{array}{c}\text { PEG } \\
(\mathbf{\%})\end{array}$ & $\begin{array}{c}\text { Agar } \\
\text { (\%) }\end{array}$ & $\begin{array}{c}\text { Intumescimento } \\
\text { (\%) }\end{array}$ & $\begin{array}{c}\text { Fração gel } \\
(\%)\end{array}$ & Aprovadas \\
\hline F-1A & 6 & 0 & 0 & - & 95,39 & Não \\
F-2A & 6 & 1,5 & 0 & 121 & 76,62 & Não \\
F-3A & 6 & 5 & 0 & 263 & 44,30 & Não \\
F-1B & 6 & 0 & 0,5 & 27 & 90,02 & Não \\
F-2B & 6 & 1,5 & 0,5 & 127 & 64,54 & Sim \\
F-3B & 6 & 5 & 0,5 & 201 & 44,17 & Não \\
F-1C & 6 & 0 & 1,5 & 49 & 78,23 & Não \\
F-2C & 6 & 1,5 & 1,5 & 104 & 46,47 & Sim \\
F-3C & 6 & 5 & 1,5 & 92 & 41,43 & Não \\
F-1D & 15 & 0 & 0 & 242 & 90,54 & Não \\
F-2D & 15 & 1,5 & 0 & 438 & 82,15 & Sim \\
F-3D & 15 & 5 & 0 & 504 & 67,73 & Não \\
F-1E & 15 & 0 & 0,5 & 218 & 93,42 & Não \\
F-2E & 15 & 1,5 & 0,5 & 256 & 85,70 & Sim \\
F-3E & 15 & 5 & 0,5 & 282 & 92,97 & Não \\
F-1F & 15 & 0 & 1,5 & 185 & 87,12 & Não \\
F-2F & 15 & 1,5 & 1,5 & 124 & 72,57 & Sim \\
F-3F & 15 & 5 & 1,5 & 121 & 68,58 & Não \\
\hline
\end{tabular}

*Formulações desenvolvidas sem papaína;

Os níveis de intumescimento obtidos variaram entre $27-438 \%$, variando de acordo com a fração gel obtida (TABELA 16), que variou entre 44-95\%. Embora esses valores de intumescimento não sejam suficientes para assegurar uma membrana capaz de absorver o exsudato formado, esses níveis permitem o emprego 
do curativo em feridas pouco exsudativas ou, no caso de feridas com muito exsudato, recomendar-se-ia a troca frequente. Os valores de fração gel obtidos revelam uma boa porcentagem de reticulação do sistema.

A seguir demonstramos a caracterização morfológica, utilizando microscópio eletrônico de varredura em diferentes resoluções das amostras selecionadas (FIGURA 59). Destaca-se a homogeneidade das membranas obtidas.

O ágar foi utilizado, considerando que ele favorece a reticulação e a formação de uma estrutura policristalina, além de assegurar a integridade da membrana previamente ao processo de irradiação, o que permite um envase adequado. Fato este observado nos experimentos, nos quais a formulação F-2C contendo 6 \% PVP e 0,5\% ágar, e a F-2D, contendo $15 \%$ PVP, apresentaram melhores resultados.
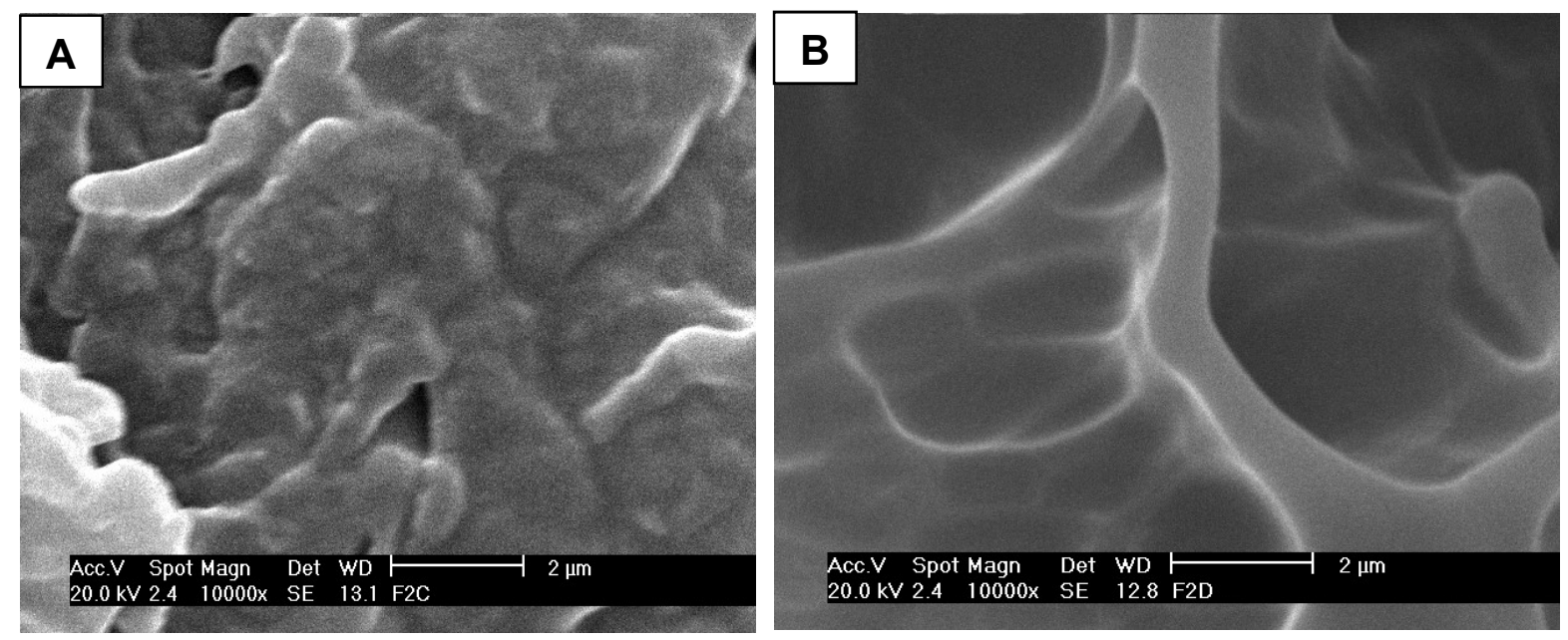

FIGURA 59 - Morfologia dos Hidrogéis desenvolvidos a base de PVP, considerando que: $\mathbf{A}-6 \%$ de PVP; $\mathbf{B}-15 \%$ de PVP.

As microscopias também indicaram (FIGURA 60 A e B) que o efeito do PEG na formação da membrana contribuiu para a homogeneidade do hidrogel, ao compararmos as formulações contendo diferentes concentrações de PEG, apresentando um perfil similar. 

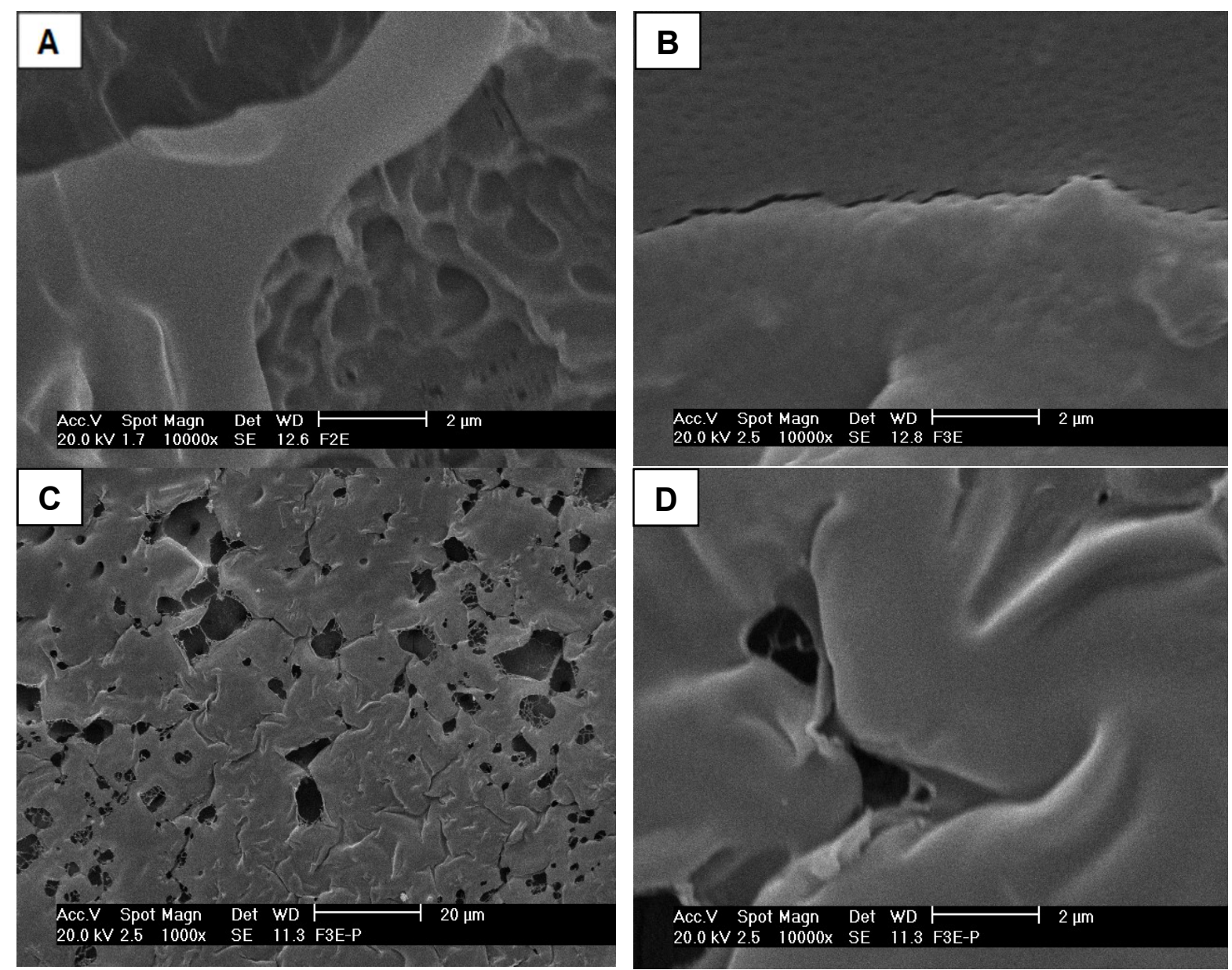

FIGURA 60 - Microscopia eletrônica dos hidrogéis à base de PVP, considerando que: A - $3 \%$ de PEG; $\mathbf{B}-5 \%$ de PEG; $\mathbf{C}-3 \%$ de PEG na presença de papaína $(0,5 \%$, p/p) com aumento de 1000x; D - 3 \% de PEG na presença de papaína de com aumento de $10.000 x$ na presença de papaína $0,5 \%$ (p/p).

Com relação à veiculação da papaína nas membranas selecionadas, todas as formulações conferiram resultados insatisfatórios - membrana de hidrogel com problemas de formação, indicando predomínio de cisão molecular ao invés de reticulação, levando à perda de viscosidade do sistema e ausência de integridade física. Exemplo de estrutura com papaína pode ser visualizado na FIGURA 60 C e D. Tais experimentos evidenciaram a necessidade de alteração do polímero-base. De maneira específica, ao adicionarmos a concentração de papaína de 0,5\% (p/p), observamos que o sistema apresenta baixa ou nenhuma capacidade de veiculação de papaína, sendo, portanto, inadequado para veiculação da enzima. 
De maneira alternativa, foi realizada a substituição do polímero empregado para o polivinil álcool, dada sua biocompatibilidade, elevada solubilidade em meio aquoso e baixo custo, vem sendo empregado extensivamente no desenvolvimento de hidrogéis.

\subsubsection{HIDROGEL DE PVA}

De modo a atender às necessidades de veiculação da papaína dentro da faixa terapêutica $(0,2-2 \%)$, foi selecionado o PVA como polímero base, dada a possibilidade de associar fenômenos de reticulação física, induzidos por ciclos de congelamento [111] e reticulação química [19], produzida em função da irradiação da amostra.

As membranas foram produzidas considerando a formulação base de $10 \%$ de PVA, concentração esta, que é usual para preparo de hidrogéis com este polímero [111], 1,5 \% de PEG e 1,5 \% de ágar, utilizando concentração de papaína de $2 \%$. Neste caso, ambas as concentrações levaram à formação da membrana, indicando maior capacidade de veiculação de papaína se comparado ao sistema obtido à base de PVP.

As embalagens desenvolvidas para preparo e acondicionamento, bem como 0 preparo dos hidrogéis desenvolvidos estão apresentados na FIGURA 61. 


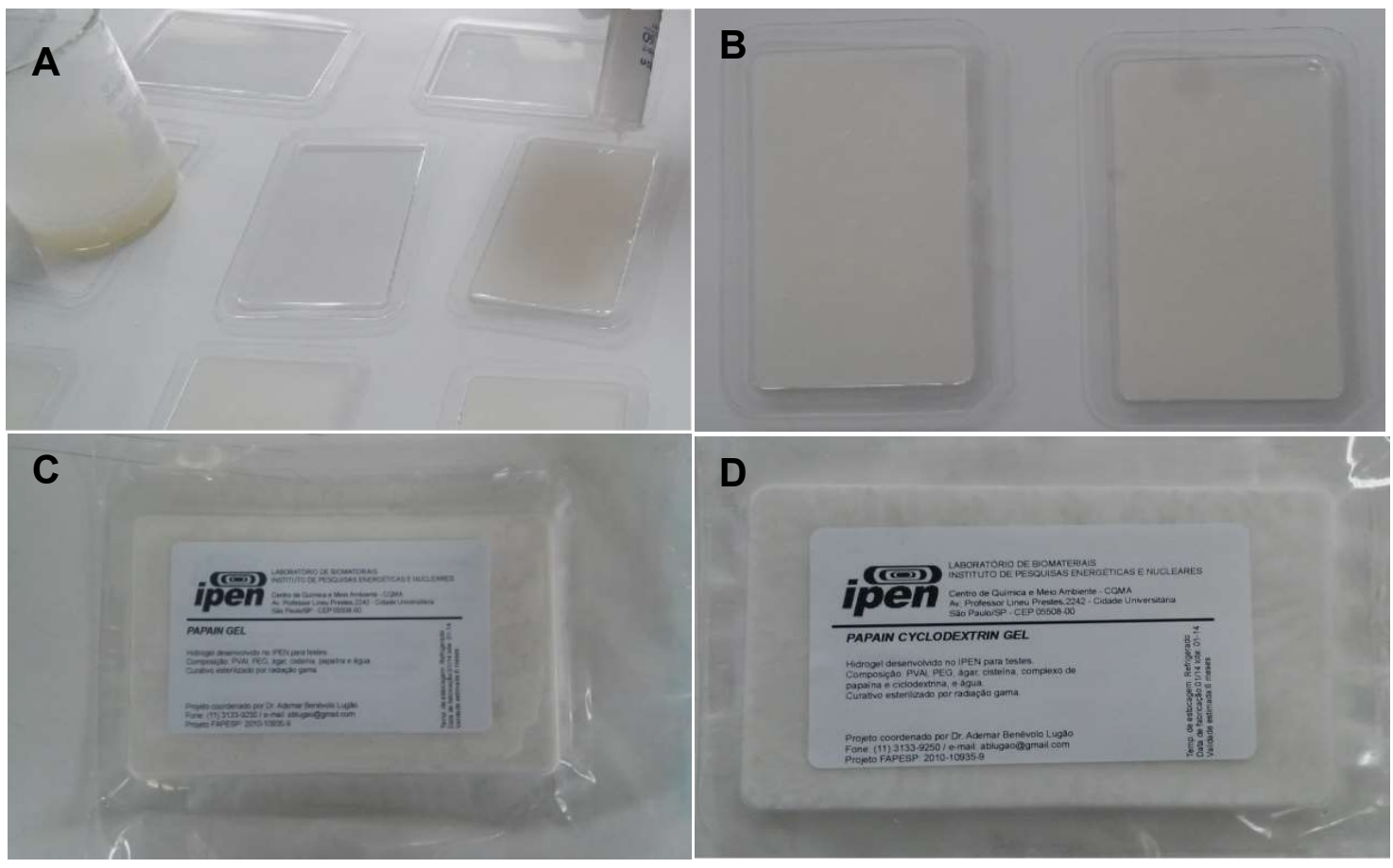

FIGURA 61 - Preparo e embalagem dos hidrogéis à base de PVA contendo papaína e o complexo de papaína e $\beta$-ciclodextrina, considerando que: $\mathbf{A}$ - disposição das soluções poliméricas nas embalagens; $\mathbf{B}$ - hidrogéis enformados; C e $\mathbf{D}$ - hidrogéis dispostos na embalagem final para e acondicionamento.

As membranas desenvolvidas a base de PVA apresentaram integridade física adequada para utilização como curativo, demonstrando propriedades físicas preservadas na presença de papaína (FIGURA 62).

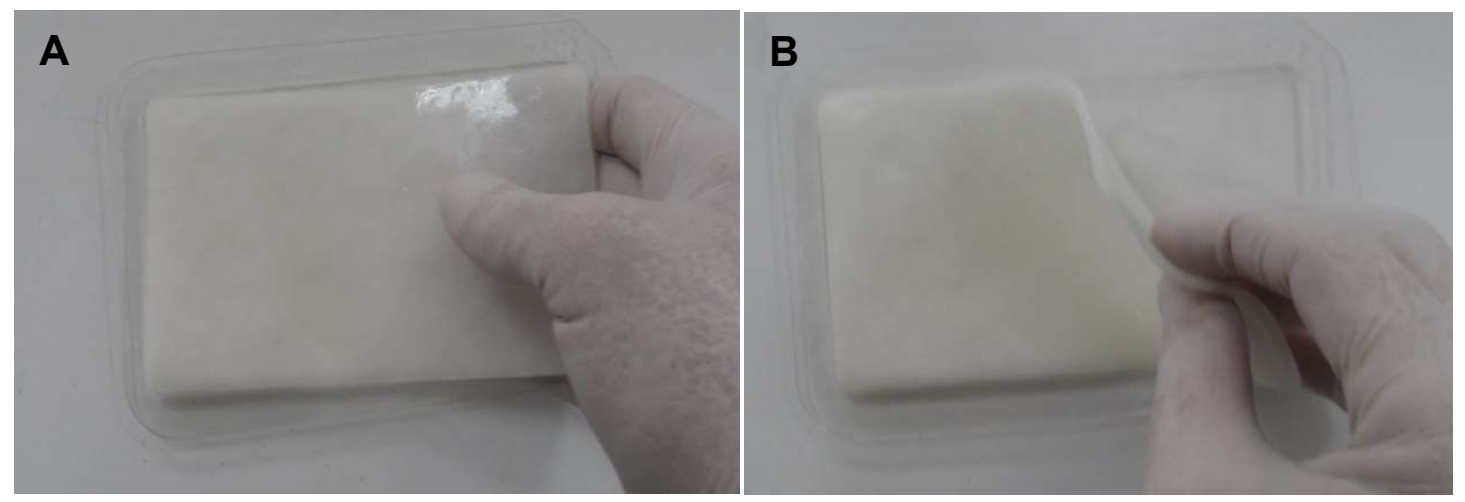

FIGURA 62 - Hidrogel contendo o complexo de papaína e $\beta$-ciclodextrina desenvolvido sendo manuseado, considerando que: $\mathbf{A}$ - ao início da remoção da placa; $\mathbf{B}$ - remoção quase completa. 
As propriedades físicas apresentadas pelos hidrogéis permitem seu uso como curativo primário, para diversas aplicações e locais (FIGURA 63), sendo ainda possível a aplicação de um curativo secundário. Adicionalmente, tais propriedades permitem também uma adequação do curativo à cada ferida, uma vez que é possível realizar o corte mecânico sem dificuldades, desde que realizado em condições assépticas.

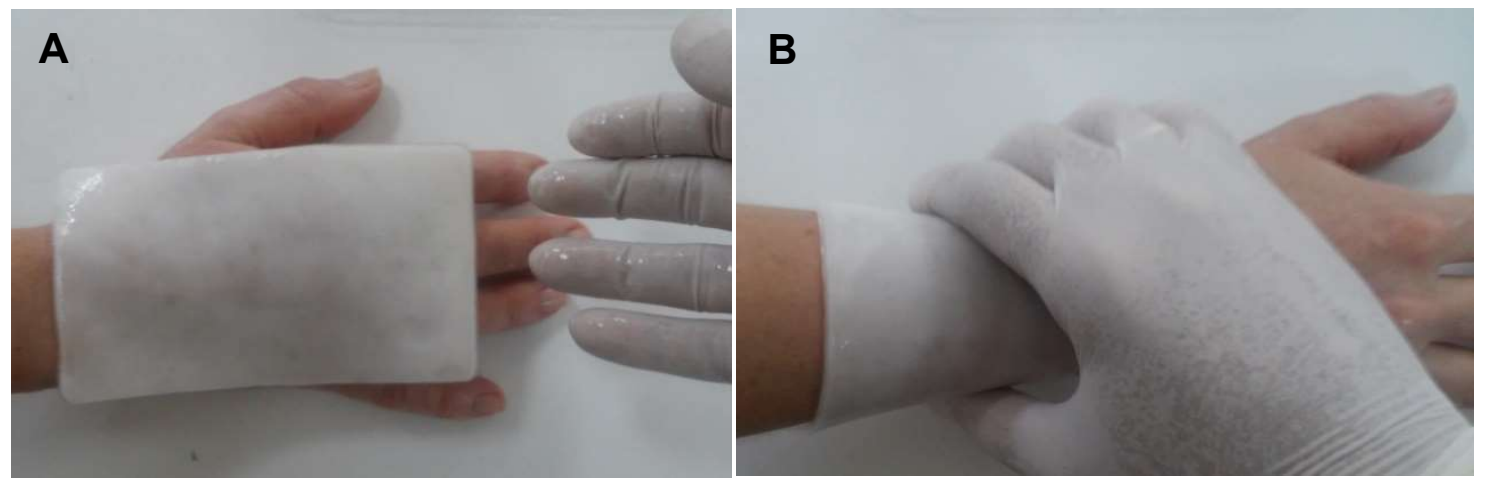

FIGURA 63 - Hidrogel desenvolvido sendo aplicado, considerando que: A - na mão; B - no antebraço.

Em suma, o hidrogel a base PVA se mostrou mais adequado para veiculação da papaína e do complexo em concentrações terapêuticas, correspondendo à forma farmacêutica alternativa ao sistema à base de PVP, observado como inadequado para veiculação de concentrações de papaína superiores a 0,5\%.

\subsubsection{PROPRIEDADES DE INTUMESCIMENTO}

O grau de intumescimento é uma propriedade relacionada com a interação polímero-solvente e o grau de reticulação do polímero. A medida é realizada considerando a massa em função do tempo. O intumescimento máximo das membranas foi atingido em torno de 8 horas e os valores estão descritos na TABELA 17. 
TABELA 17 - Avaliação das propriedades de intumescimento máximo dos hidrogéis desenvolvidos à base de PVA.

\begin{tabular}{lcc}
\hline Formulação & $\begin{array}{c}\text { Intumescimento } \\
\text { máximo (\%) }\end{array}$ & Desvio padrão \\
\hline A & 8,11 & 0,027 \\
B & 10,31 & 0,028 \\
C & 10,58 & 0,016 \\
D & 10,62 & 0,021 \\
E & 10,93 & 0,014 \\
F & 15,95 & 0,028 \\
G & 9,12 & 0,014 \\
Controle (1 ciclo) & 375,36 & 0,032 \\
Controle (3 ciclos) & 85,73 & 0,040 \\
\hline
\end{tabular}

Os hidrogéis a base de PVA apresentam, em geral, baixa capacidade de intumescimento. No caso do emprego da radiação ionizante associada a cristalização como rota de síntese, os níveis de intumescimento atingidos estavam na faixa de 8$15 \%$ na presença de papaína, dependendo da formulação (TABELA 17). A formulação $F$ apresentou maior capacidade de intumescimento, enquanto a formulação $A$, apresentou menores índices. Tal efeito pode ser atribuído a presença da ciclodextrina e cisteína, no entanto, a variação é pouco significativa.

Os hidrogéis controle, contendo apenas PVA, PEG e ágar apresentaram propriedades de intumescimento muito superiores aos obtidos para as mesmas membranas na presença de proteína e dos outros componentes (TABELA 17). Corroborando os resultados da literatura [49], a presença de proteínas acarreta diminuição intensa das propriedades de intumescimento apresentadas pelo hidrogel. Atribui-se tal efeito a alterações na pressão osmótica, e no tamanho de poros da rede formada, dificultando assim a expansão das cadeias poliméricas e reduzindo a absorção de água, por consequência [77].

Ao compararmos a influência dos ciclos de congelamento na formação do hidrogel destacamos que (TABELA 17) quanto mais se congela, mais se diminui o 
intumescimento, decorrente da formação de uma estrutura cristalina mais densa e rígida, e redução da fase amorfa.

De maneira prática, as propriedades de intumescimento são relevantes uma vez que esta propriedade está relacionada com possível capacidade de absorção de fluidos e exsudato pela membrana, podendo ou não restringir a aplicação do curativo em feridas exsudativas e, neste caso, é possível estabelecer que estes sistemas são mais recomendados para aplicação em feridas pouco exsudativas. No caso do debridamento de feridas exsudativas, uma solução pode ser utilizar o curativo por menos tempo, realizando trocas recorrentes, de modo a permitir uma manutenção adequada da ferida.

\subsubsection{FRAÇÃO GEL}

A fração gel é uma propriedade que avalia a porcentagem reticulada do sistema. No caso das formulações à base de PVA, os valores de fração gel variaram pouco, entre $82-86$ \% (TABELA 18). Destaca-se que o processo de cristalização associado a reticulação por radiação permitiu uma nanoestruturação adequada do sistema na presença de papaína.

TABELA 18 - Avaliação da fração gel dos hidrogéis à base de PVA desenvolvidos.

\begin{tabular}{lcc}
\hline Formulações & Fração Gel (\%) & Desvio padrão \\
\hline A & 83,84 & 0,742 \\
B & 86,02 & 1,095 \\
C & 84,33 & 0,177 \\
D & 82,69 & 0,117 \\
E & 83,48 & 1,717 \\
F & 85,30 & 0,075 \\
G & 82,19 & 0,585 \\
Controle (1 ciclo) & 93,35 & 1,15 \\
Controle (3 ciclos) & 87,70 & 2,01 \\
\hline
\end{tabular}


A principal diferença entre os hidrogéis de PVA e PVP é que o primeiro recebe grande influência da temperatura, podendo ou não desencadear um fenômeno denominado cristalização [111]. Esta cristalização, não apenas confere resistência mecânica à membrana como aproxima e reduz a quantidade de regiões amorfas dos polímeros.

Conforme podemos observar na TABELA 18 a fração gel diminuiu com os ciclos de congelamento. Tal fenômeno ocorre uma vez que a redução da fase amorfa, região-alvo das reticulações, restringe consideravelmente os sítios disponíveis para formação de reticulações [19,111]. Embora os valores de fração gel obtidos foram altos para os sistemas, especula-se que tais reticulações sejam majoritariamente físicas, e químicas em uma menor escala, indicando que o fenômeno da cristalização desempenha papel majoritário na manutenção da estrutura e integridade física do material.

Embora o hidrogel B tenha apresentado maiores índices de fração gel, tal valor é mínimo se comparado as demais formulações contendo papaína e na ausência de papaína, evidenciando experimentalmente que a presença dos demais componentes da formulação não exercem efeito significativo sobre a formação das reticulações e consequentemente da fração gel.

\subsubsection{DENSIDADE DE RETICULAÇÃO}

A densidade de reticulação revela detalhes sobre a nanoestrutura do material em se tratando de distribuição e tamanho médio dos poros do hidrogel. A avaliação da densidade de reticulação dos hidrogéis está descrita na TABELA 19.

Os níveis de densidade de reticulação dos sistemas avaliados indicaram uma diminuição da densidade de reticulação na presença de papaína e dos outros componentes. Na presença de ciclodextrina (formulação F) destaca-se uma maior densidade de reticulação, se comparado aos demais.

Embora tais diferenças tenham sido observadas, não houve distinção no perfil de liberação, indicando que na faixa de densidade de reticulação atingida não existem variações significativas com relação ao perfil de liberação. 
TABELA 19 - Valores de densidade de reticulação obtidos para os hidrogéis à base de PVA desenvolvidos para veiculação do complexo.

\begin{tabular}{lc}
\hline Formulações & Densidade de reticulação $\left.\mathbf{( M o l} / \mathbf{c m}^{3}\right)$ \\
\hline A & $2,93 \cdot 10^{-3}$ \\
B & $1,58 \cdot 10^{-3}$ \\
C & $1,48 \cdot 10^{-3}$ \\
D & $1,46 \cdot 10^{-3}$ \\
E & $1,36 \cdot 10^{-3}$ \\
F & $5,08 \cdot 10^{-4}$ \\
G & $2,167 \cdot 10^{-2}$ \\
PVA (1 ciclo) & $2,10^{-2}$ \\
PVA (3 ciclos) & $4,93 \cdot 10^{-1}$ \\
\hline
\end{tabular}

$\mathrm{Na}$ ausência de proteínas, observou-se que a densidade de reticulação atingiu valores muito superiores, evidenciando que o sistema se comporta de maneira distinta na presença da proteína. Tal fenômeno pode ser explicado pelo fato de que, na ausência de proteína, a reticulação não encontra barreiras ou implicações estereoquímicas, levando à formação de um hidrogel com maior densidade de reticulação.

A distribuição das proteínas na forma farmacêutica corresponde a um parâmetro de avaliação da qualidade do material, uma vez que uma membrana heterogênea não permitiria um debridamento adequado e uniforme, além de influenciar em outras propriedades, como as mecânicas, que podem acarretar em porções mais rígidas e outras mais frágeis.

O reagente de Bradford, corante específico para proteínas, ao entrar em contato com proteínas, adquire uma coloração azul, e permite ensaio a nível quantitativo e qualitativo. Destacamos que tal corante não possui interação com o polímero. Observou-se uma distribuição homogênea do corante sobre a membrana, evidenciando distribuição homogênea da papaína no hidrogel (FIGURA 64). 


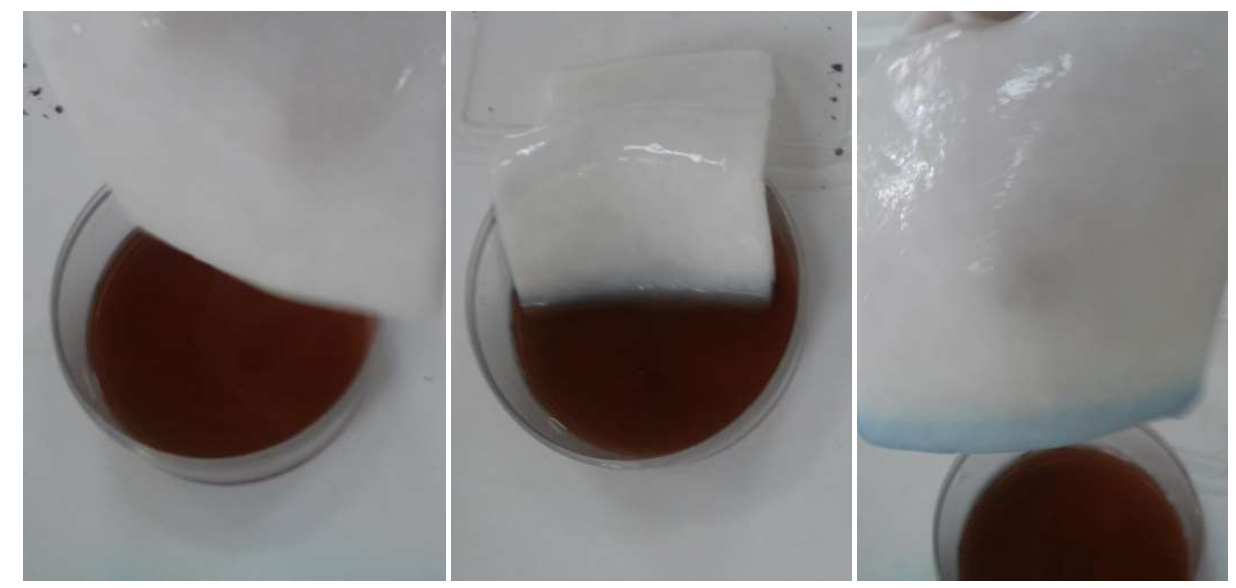

FIGURA 64 - Avaliação da distribuição das proteínas no hidrogel contendo complexo de papaína e $\beta$-ciclodextrina desenvolvido.

\subsubsection{VEICULAÇÃO DA PAPAÍNA E DO COMPLEXO}

A adição da papaína em etapa final permite redução nas etapas de processo, que poderiam acarretar perda de atividade biológica, minimizando a degradação enzimática relacionada à produção do hidrogel.

É relevante destacar que a formação dos hidrogéis à base de PVA não dependeu apenas da reticulação química promovida pela radiação, como foi observado para os hidrogéis à base de PVP. A cristalização permitiu associar a manutenção da atividade biológica e melhora nas propriedades da membrana, além de permitir a veiculação de maiores quantidades de papaína, efeito este que não ocorreu de maneira tão pronunciada em hidrogéis à base de PVP.

Com relação à translucidez, a adição de papaína em maiores concentrações contribuiu para uma perda considerável de translucidez dos hidrogéis. Adicionalmente, um comprometimento maior neste aspecto foi observado nos hidrogéis de PVA, decorrente da cristalização, que levou a formação de um hidrogel branco e opaco. Tal fenômeno não foi observado quando o PVP foi utilizado. 


\subsubsection{AVALIAÇÃO DA LIBERAÇÃO DO COMPLEXO PELO HIDROGEL}

A liberação da membrana foi simulada em sistema tampão (FIGURA 65) utilizando $\circ \mathrm{pH}$ fisiológico. Observa-se uma liberação pouco significativa nos momentos iniciais (até 6 horas de incubação). Decorridas 24 horas, o sistema atinge seu equilíbrio, e a liberação é mantida estável até as 48 horas de incubação.

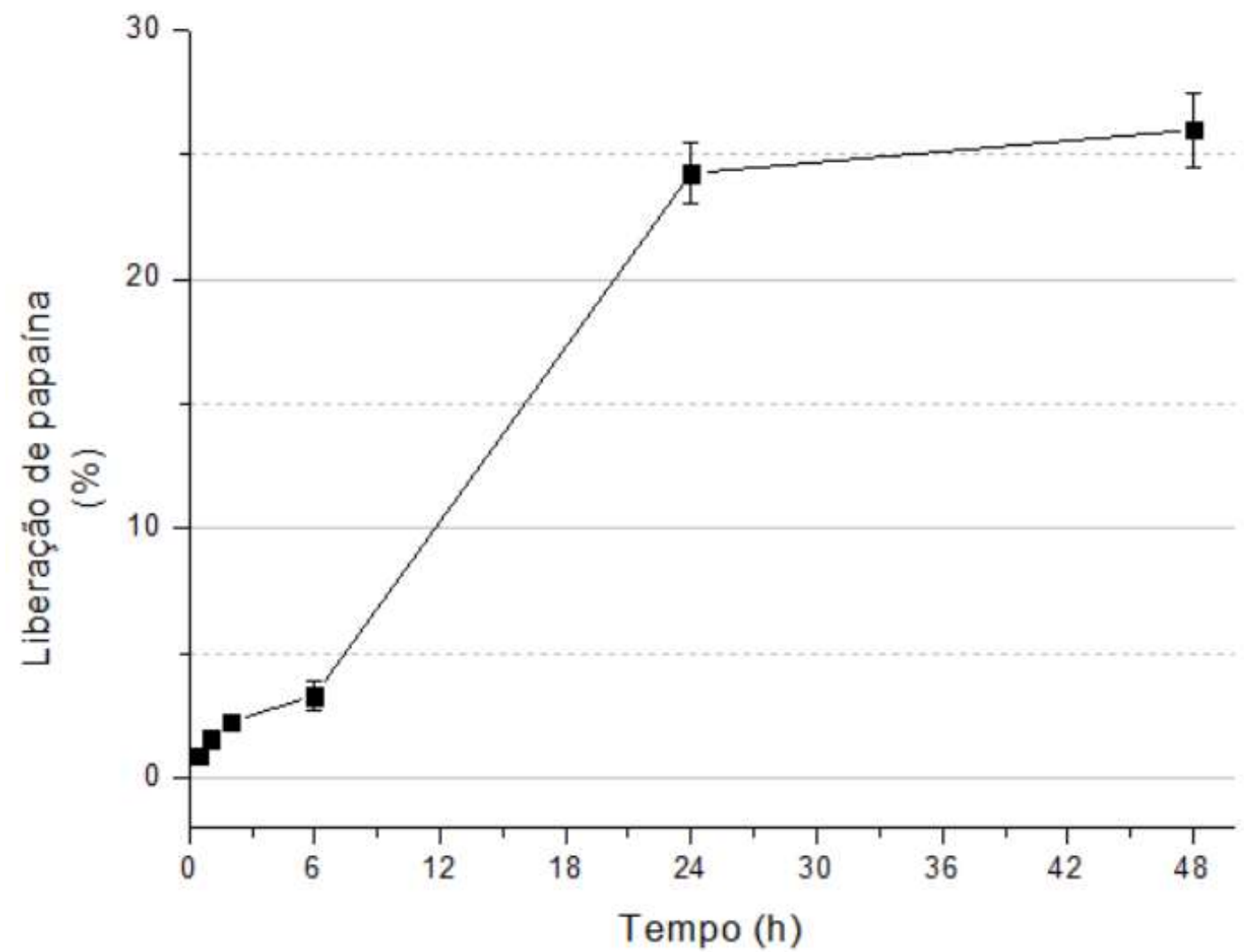

FIGURA 65 - Perfil de liberação dos hidrogéis à base de PVA.

Destaca-se que o perfil de liberação é muito similar ao perfil de intumescimento, confirmando a imobilização por enredamento, uma vez que, alterados os tamanhos dos poros, a liberação ocorre. Não foi observado um efeito "burst" inicial, conforme observado para outros hidrogéis poliméricos [113].

É relevante destacar que para a aplicação desejada, ou seja, na ferida, o contato do hidrogel com os fluidos biológicos é muito menor do que o contato promovido no ensaio, e, desta forma, os resultados indicam que existiria pouca ou 
nenhuma liberação e os efeitos seriam promovidos por efeito de contato. Tal informação é relevante uma vez que pode acarretar em menor taxa de reações adversas e problemas atribuídos ao emprego da papaína. O efeito terapêutico, então, seria promovido por efeito de contato majoritariamente.

A ausência de liberação nos momentos iniciais pode ser um indicativo de uma boa distribuição da proteína na membrana, uma vez que esse efeito inicial tende a ocorrer em função da liberação das proteínas presentes na superfície do hidrogel [114].

Ao observarmos a cinética de liberação da papaína e do complexo nas membranas desenvolvidas, observou-se um perfil similar, corroborando os resultados obtidos, nos quais pouca variação em outras propriedades como fração gel e intumescimento foram relatadas. A liberação da papaína ocorreu em torno de $26 \%$ do conteúdo inicial, evidenciando uma nanoestrutura capaz de impedir essa liberação e, dessa forma, tentar minimizar os efeitos adversos promovidos.

A avaliação da atividade biológica frente ao tempo (coletado após 24 horas de incubação) revelou que, destes $26 \%$ comparado à solução mãe contendo papaína a $2 \%$, a bioatividade medida é equivalente a uma atividade de $14,42 \%$, indicando a perda de atividade em função do processo estabelecida como aproximadamente 45 $\%$.

A FIGURA 66 revela o perfil de atividade dos hidrogéis contendo papaína e complexo frente ao hidrogel contendo apenas papaína nativa (hidrogel B). Observase que na presença de trealose e ciclodextrina, ambos com cisteína (formulação $\mathrm{F} \mathrm{e}$ $G)$, foram obtidos os valores máximos de atividade, indicando que o efeito da ciclodextrina foi similar ao do emprego da trealose.

O efeito da concentração de cisteína também influiu na bioatividade, indicando que, mesmo em concentrações baixas, esta molécula não só auxilia na atividade da enzima, mas atua na manutenção de sua estabilidade, conforme descrito em literatura [115]. 


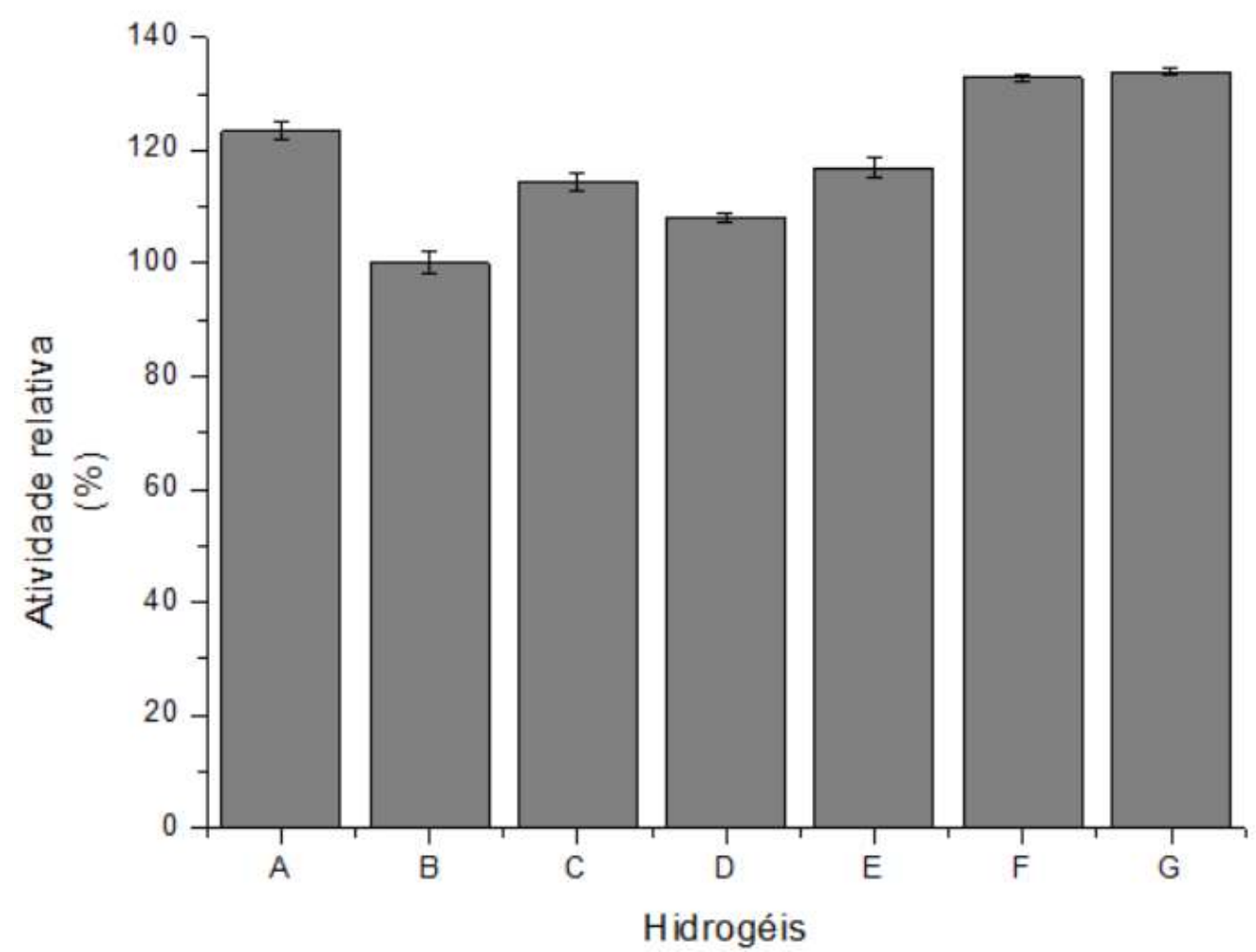

FIGURA 66 - Avaliação da bioatividade dos hidrogéis desenvolvidos 7 dias após irradiação.

\subsubsection{AVALIAÇÃO DO POTENCIAL CITOTÓXICO DO HIDROGEL}

\section{PBMC}

A citocompatibilidade do material foi avaliada frente às células mononucleares do sangue periférico, revelando o potencial citotóxico da forma farmacêutica. A FIGURA 67 contém os resultados de viabilidade celular obtidos após estímulo de 24 horas com os hidrogéis por contato direto.

A intenção deste teste foi de avaliar os possíveis efeitos citotóxicos da forma farmacêutica associada ao ativo. Os resultados indicaram um perfil citotóxico similar para todos os géis. No entanto, foi observado que ocorreu absorção do meio de cultura que continha as células suspensas durante o experimento, o que levou a uma contagem reduzida de células e baixos índices de viabilidade celular. 


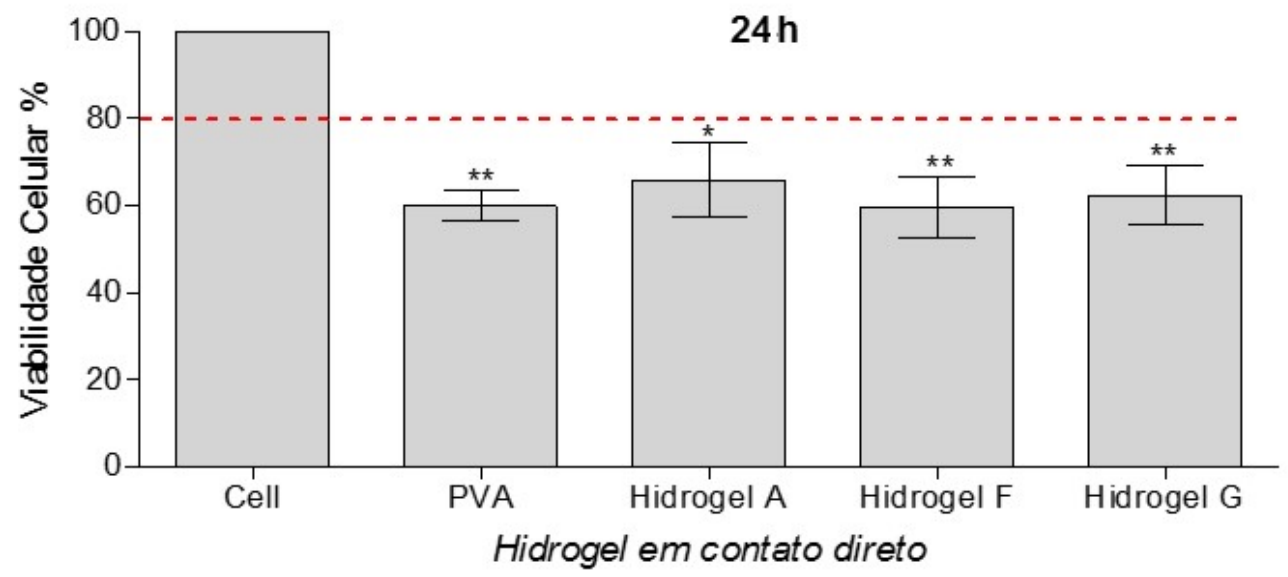

FIGURA 67 - Ensaio de citotoxicidade dos hidrogéis à base de PVA em contato direto com células mononucleares do sangue periférico.

O ensaio de citotoxicidade indireta das membranas foi realizado conforme preconizado pelas normas estabelecidas para avaliação biológica de biomateriais [93]. Para tanto, foram realizadas extrações dos hidrogéis e os volumes de meio extrator foram calculados com base na capacidade de intumescimento das membranas.

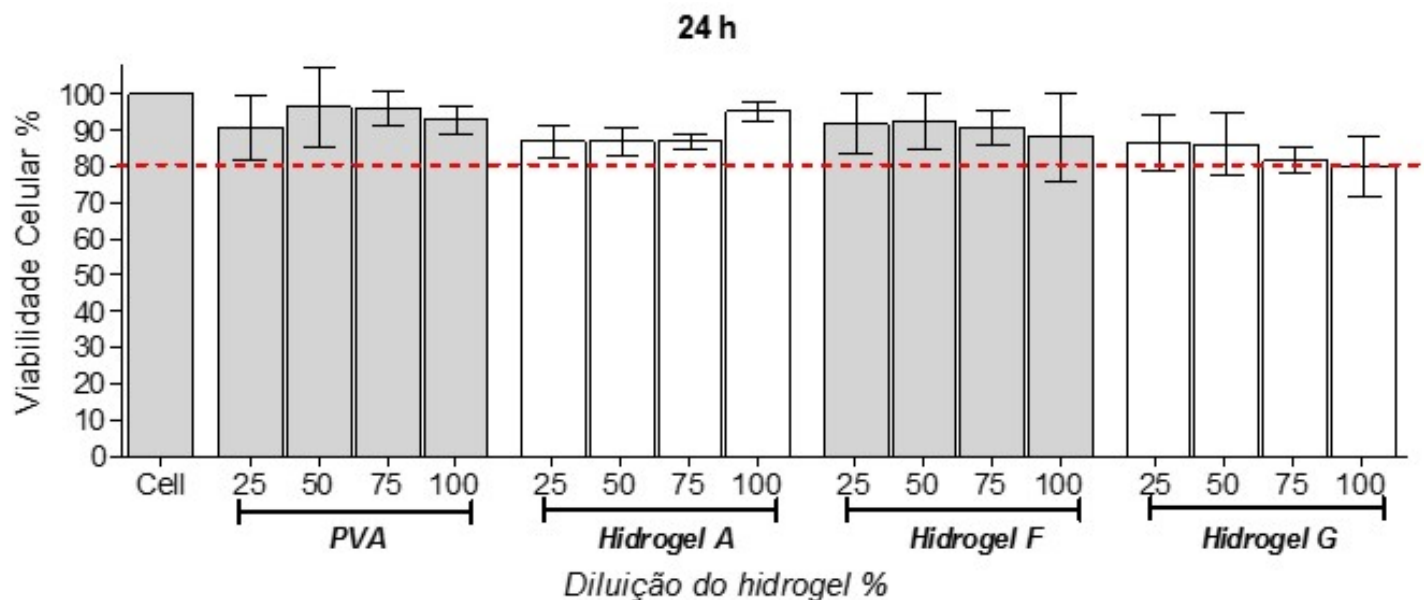

FIGURA 68 - Ensaio de citotoxicidade das extrações dos hidrogéis à base de PVA com células mononucleares do sangue periférico. 
Após estímulo de 24 horas com os extratos dos hidrogéis destaca-se uma citocompatibilidade adequada, não tendo sido observadas concentrações citotóxicas para nenhuma das concentrações dos extratos utilizados.

Decorridas 72 horas de estímulo (FIGURA 69) nenhuma toxicidade foi observada. Efeitos de proliferação celular foram observados, evidenciados pelo aumento da viabilidade celular se comparados às células isoladas.

No caso da papaína livre, tanto o tempo quanto a concentração são fatores importantes para desencadear a toxicidade da papaína. No entanto, para os hidrogéis desenvolvidos, não foram observados tais efeitos, devido à baixa liberação da papaína e do complexo por parte do hidrogel, além do efeito citoprotetor promovido pela ciclodextrina.

O conceito envolvido nas diluições é atribuído à possibilidade da presença de compostos tóxicos na formulação, como monômeros ou outros fragmentos possivelmente gerados na formação da membrana. Para tanto, o processo de extração foi realizado de maneira a garantir que a papaína presente estaria inativada. Entretanto, nas condições em que o teste foi realizado, as membranas não apresentaram citotoxicidade, estando de acordo com o que preconiza a norma para biomateriais [93].

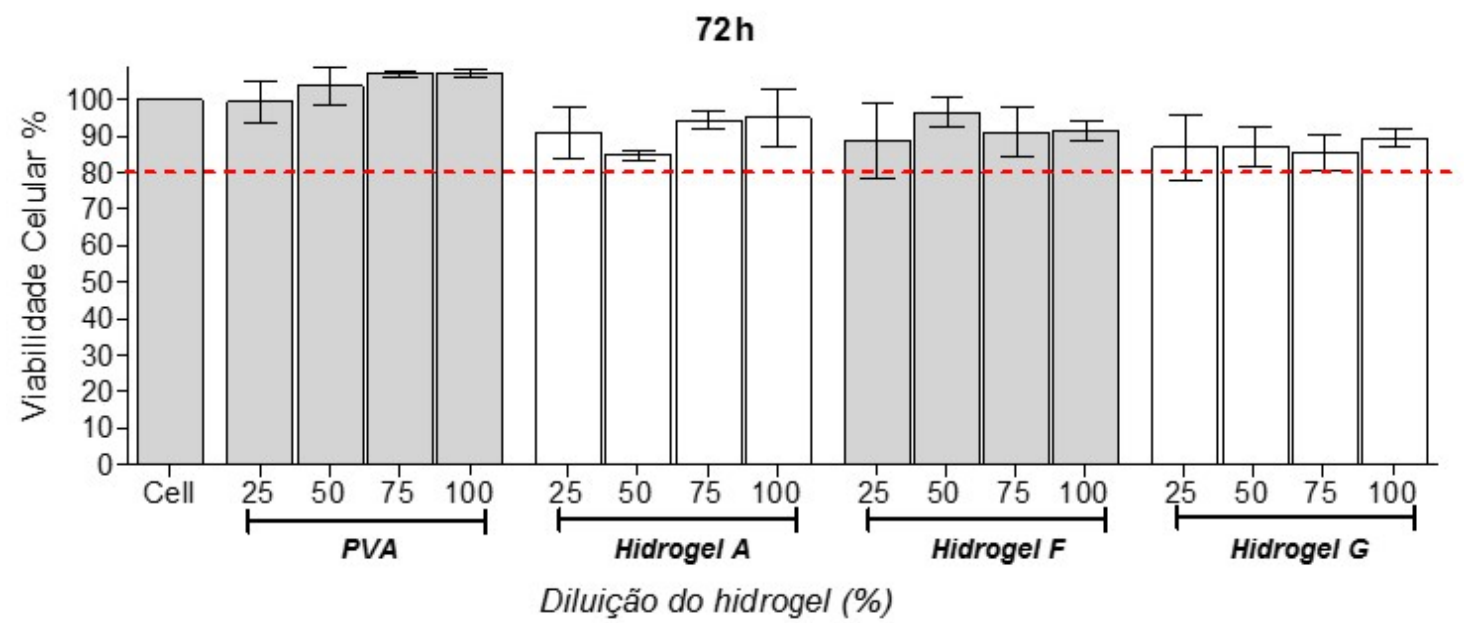

FIGURA 69 - Ensaio de citotoxicidade das extrações dos hidrogéis à base de PVA com células mononucleares do sangue periférico após 72 horas de estimulo. 


\subsubsection{AVALIÇÃO DO POTENCIAL INFLAMATÓRIO E IMUNOGÊNICO}

\section{DOSAGEM DE CITOCINAS}

A dosagem de citocinas foi realizada após o estímulo das células mononucleares do sangue periférico por 5 dias. As citocinas envolvidas na resposta dos esplenócitos frente ao estímulo do hidrogel corresponderam a IL2, IL6, IFNy, TNFa e IL10.

Com relação a IL2, destaca-se que o efeito foi desencadeado pelos extratos, indicando que por contato direto, não existe papaína suficiente para desencadear tal resposta. Os resultados obtidos estão descritos na FIGURA 70.

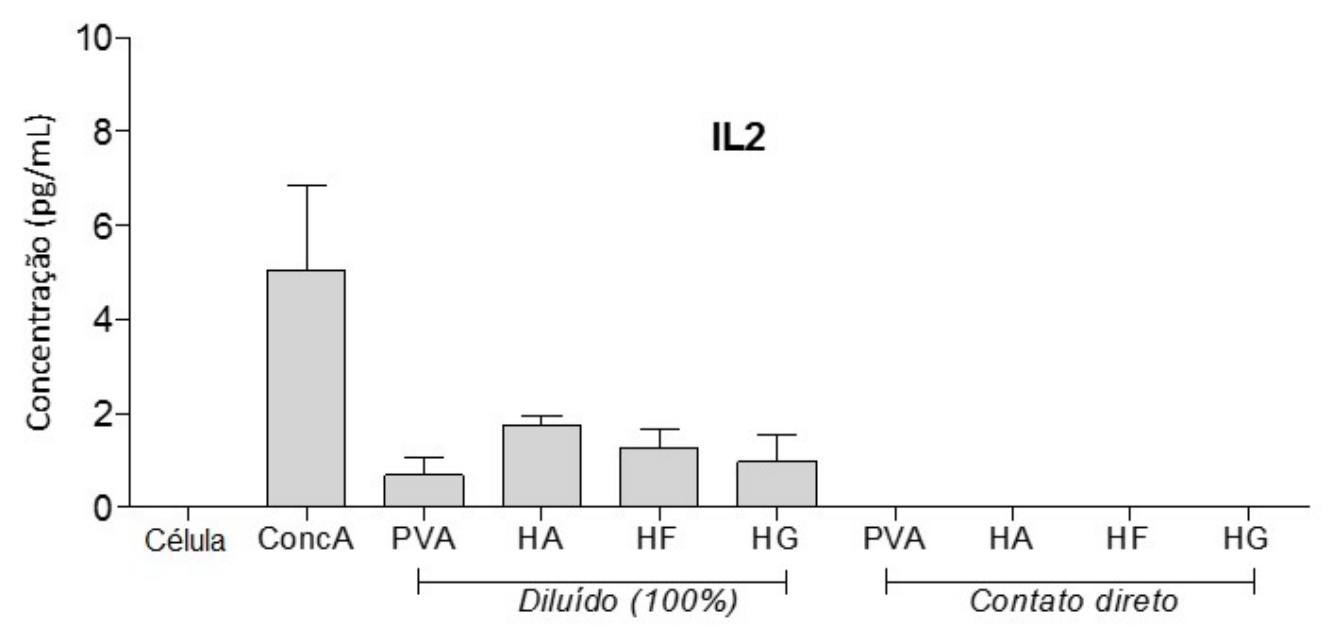

FIGURA 70 - Dosagem de IL2 produzidas por esplenócitos murinos expostos ao hidrogel e suas extrações, realizada por citometria de fluxo usando o kit CBA.

A IL6 foi observada para as diluições e apenas para o PVA isolado, indicando que a membrana sozinha é também capaz de desencadear resposta inflamatória. Entretanto, tal resposta é inibida na presença da papaína e do complexo (FIGURA 71). 


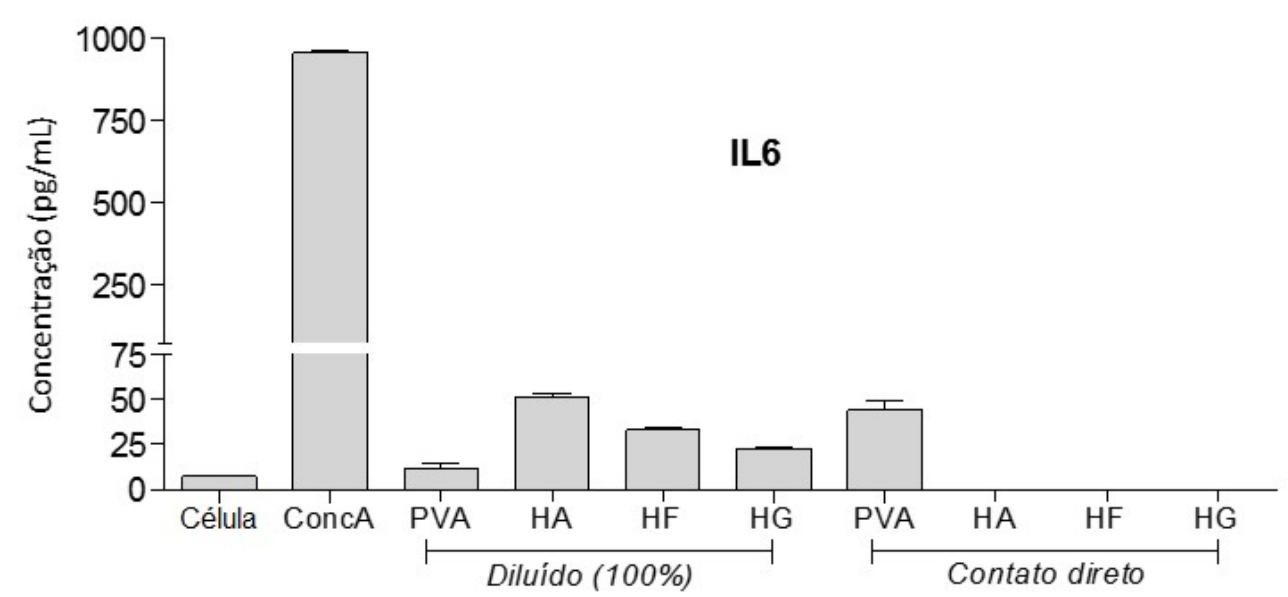

FIGURA 71 - Dosagem de IL6 produzidas por esplenócitos murinos expostos ao hidrogel e suas extrações, realizada por citometria de fluxo usando o kit CBA.

Os níveis de IFNy obtidos são inferiores ao nível basal celular e, portanto, estes efeitos são desprezíveis (FIGURA 72).

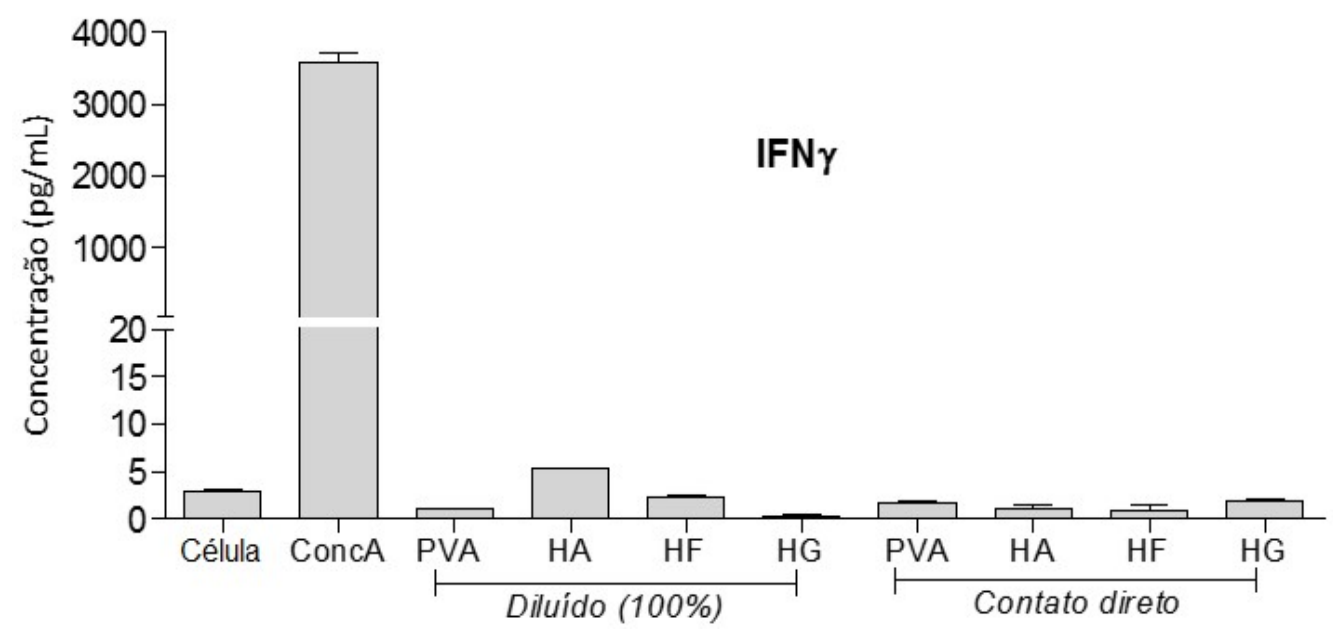

FIGURA 72 - Dosagem de IFNy produzidas por esplenócitos murinos expostos ao hidrogel e suas extrações, realizada por citometria de fluxo usando o kit CBA.

O hidrogel apresentou, também, um efeito sobre a produção de TNFa; porém, tal efeito parece estar relacionado com o polímero ou demais constituintes da matriz, uma vez que a formulação não induziu resposta por contato direto, apenas a membrana controle (FIGURA 73). 


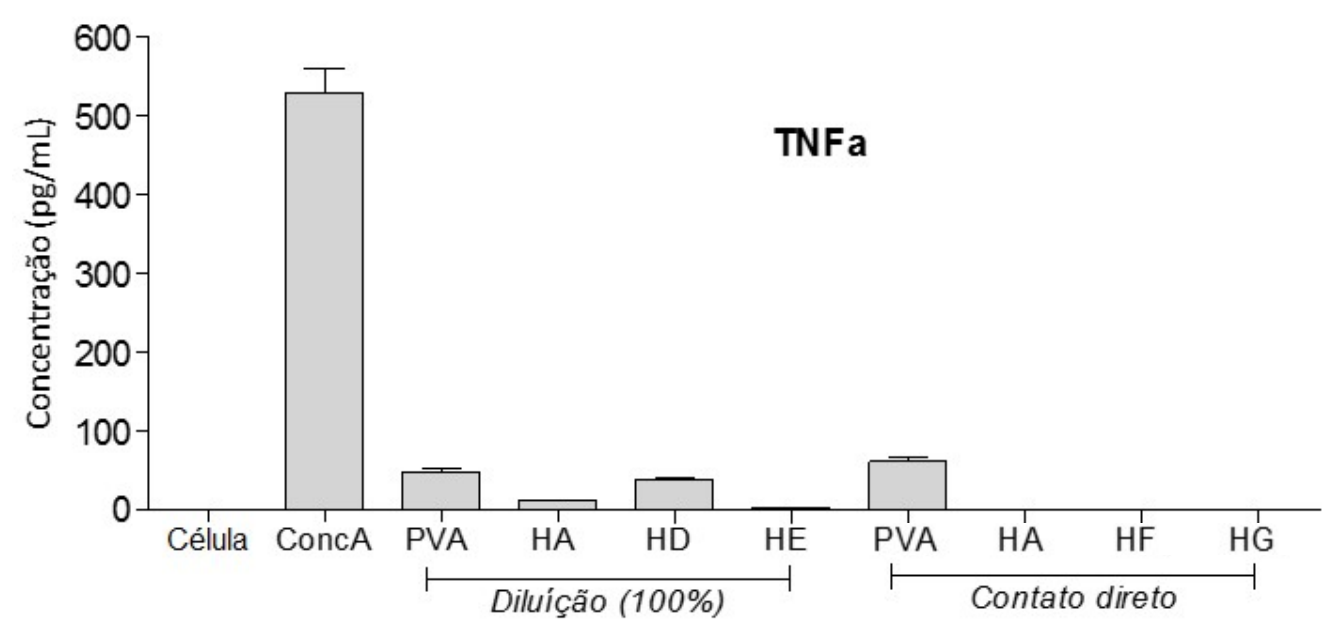

FIGURA 73 - Dosagem de TNFa, produzidas por esplenócitos murinos expostos ao hidrogel e suas extrações, realizada por citometria de fluxo usando o kit CBA.

É relevante destacar que um dos principais efeitos do estímulo com papaína observados corresponde aos níveis de IL10. Destaca-se que com relação ao hidrogel por contato direto, tal efeito não é observado (FIGURA 74). Esta informação permite compreender que os efeitos observados estão relacionados com a membrana em si, envolvendo de forma mais expressiva os mediadores pró e anti-inflamatórios, e outros que não foram observados para a papaína.

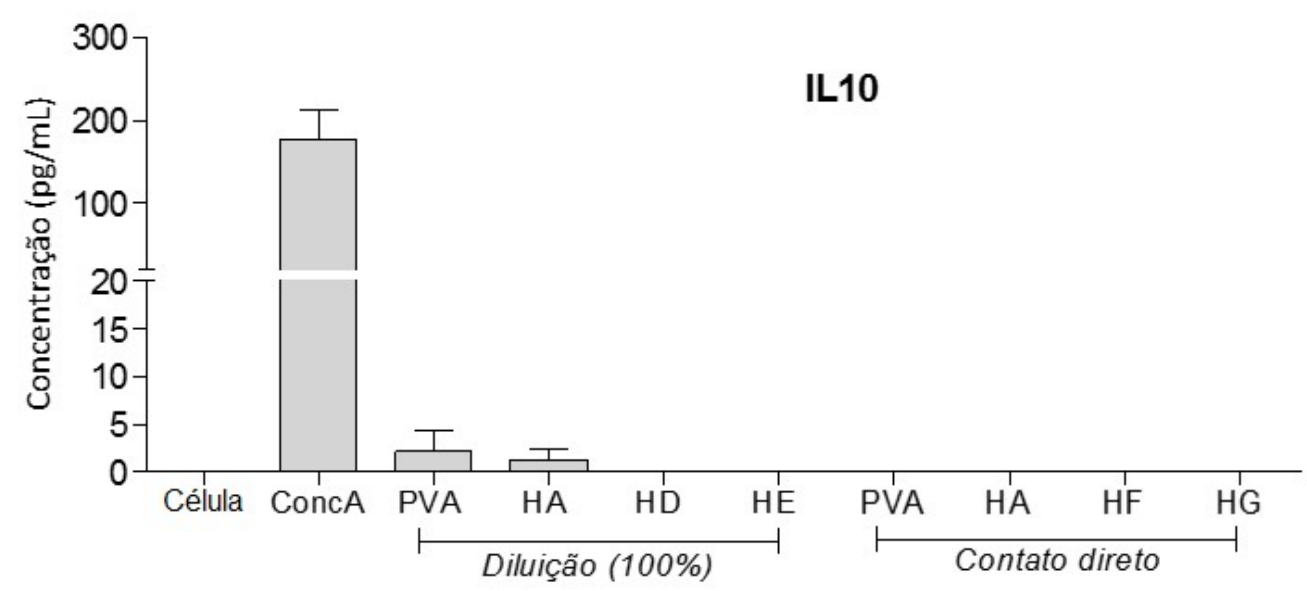

FIGURA 74 - Dosagem de IL10 produzidas por esplenócitos murinos expostos ao hidrogel e suas extrações, realizada por citometria de fluxo usando o kit CBA. 
Estes resultados indicam que o hidrogel desenvolvido apresenta potencial como uma forma de administração da papaína que, dada a sua nanoestrutura, não permite uma liberação significativa da papaína, minimizando, desta forma, os efeitos indesejáveis relacionados ao emprego da papaína, com ação através do contato. Adicionalmente, tais efeitos podem ser minimizados de modo mais efetivo se utilizarmos o complexo ao invés da enzima nativa.

\section{AVALIAÇÃO DO POTENCIAL ANTIMICROBIANO DO HIDROGEL}

A abordagem das propriedades antimicrobianas de dispositivos se torna relevante ao considerarmos a possibilidade de auxiliar na manutenção e recuperação da ferida através do controle da carga microbiana local, assim como diminuir a necessidade do emprego de agentes antibióticos ou biocidas utilizados e, consequentemente, reduzir a necessidade de intervenções cirúrgicas.
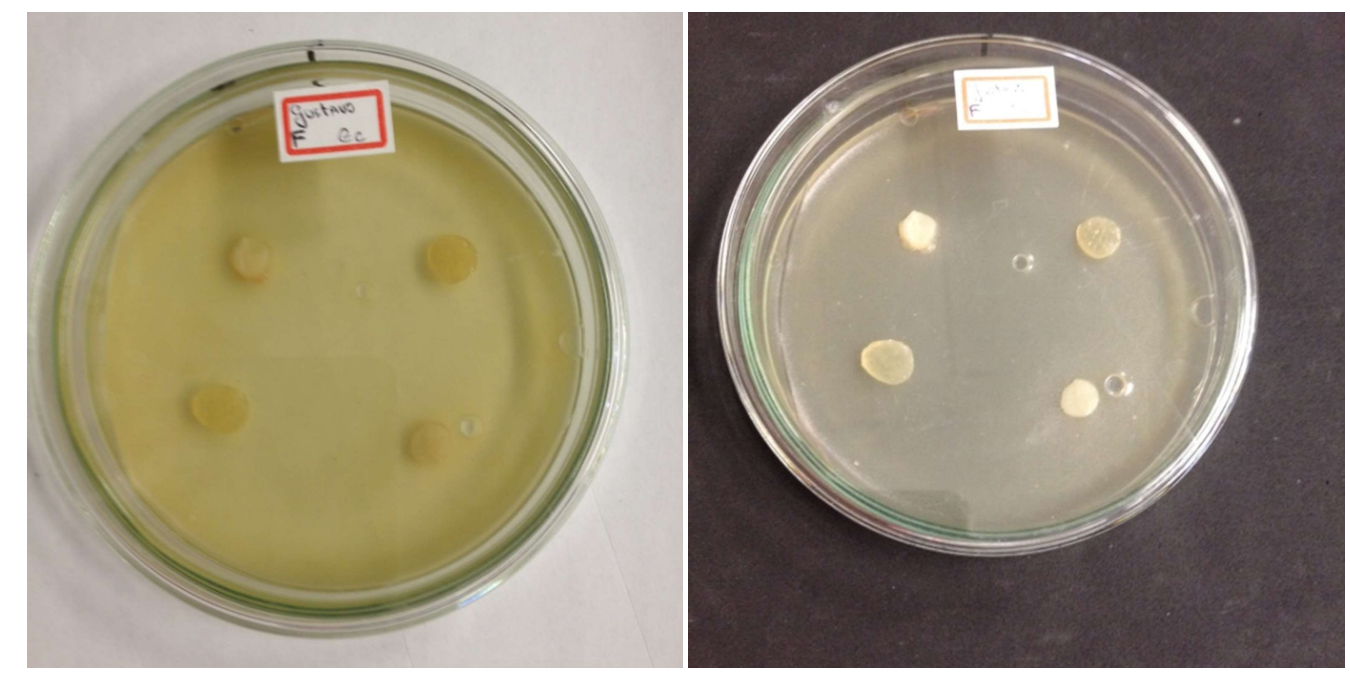

FIGURA 75 - Avaliação das propriedades antimicrobianas dos hidrogéis de PVA contendo papaína, complexo de papaína e $\beta$-ciclodextrina frente a cepa de Escherichia coli (ATCC 8739) em meio TSB utilizando método de difusão em disco.

De modo a avaliar as propriedades biocidas da forma farmacêutica, os hidrogéis à base de PVA contendo a papaína e o complexo (formulações $A, B, F$ e G) foram avaliados com relação a sua atividade contra bactérias gram positivas - 
Staphylococcus aureus; gram negativas - Escherichia coli e Pseudomonas aeruginosa, Klebsiella pneumoniae; fungo - Candida albicans;

A seleção de tais microrganismos, além de ter sido realizada em conformidade com a literatura específica [92], engloba os principais grupos de microrganismos patogênicos. Na FIGURA 75, os efeitos dos hidrogéis sobre o crescimento de Escherichia coli, ao contrário de um efeito inibitório, foi observado um crescimento sobre a superfície do hidrogel.

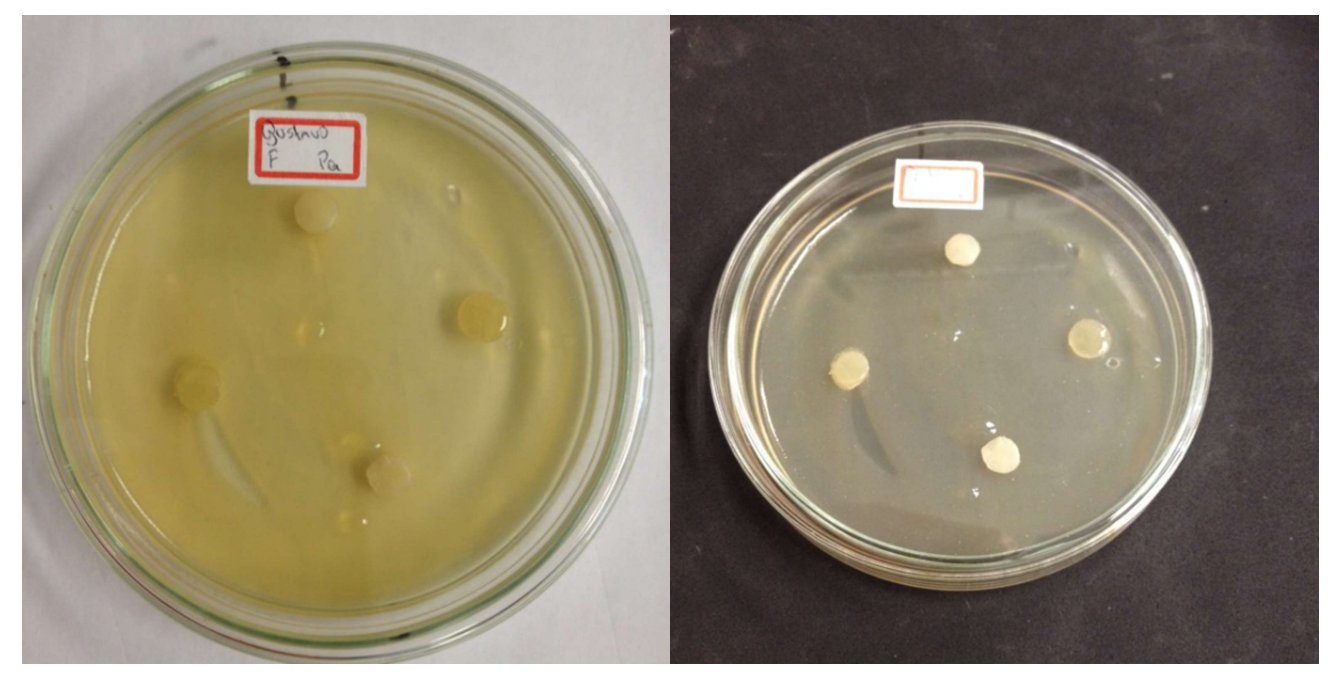

FIGURA 76 - Avaliação das propriedades antimicrobianas dos hidrogéis de PVA contendo papaína e complexo de papaína e $\beta$-ciclodextrina frente a cepa de Pseudomonas aeruginosa (ATCC 9027) em meio TSB utilizando método de difusão em disco.

O mesmo caso ocorreu quando avaliamos os hidrogéis frente a linhagens de Pseudomonas (FIGURA 76) e Staphylococcus aureus (FIGURA 77). 


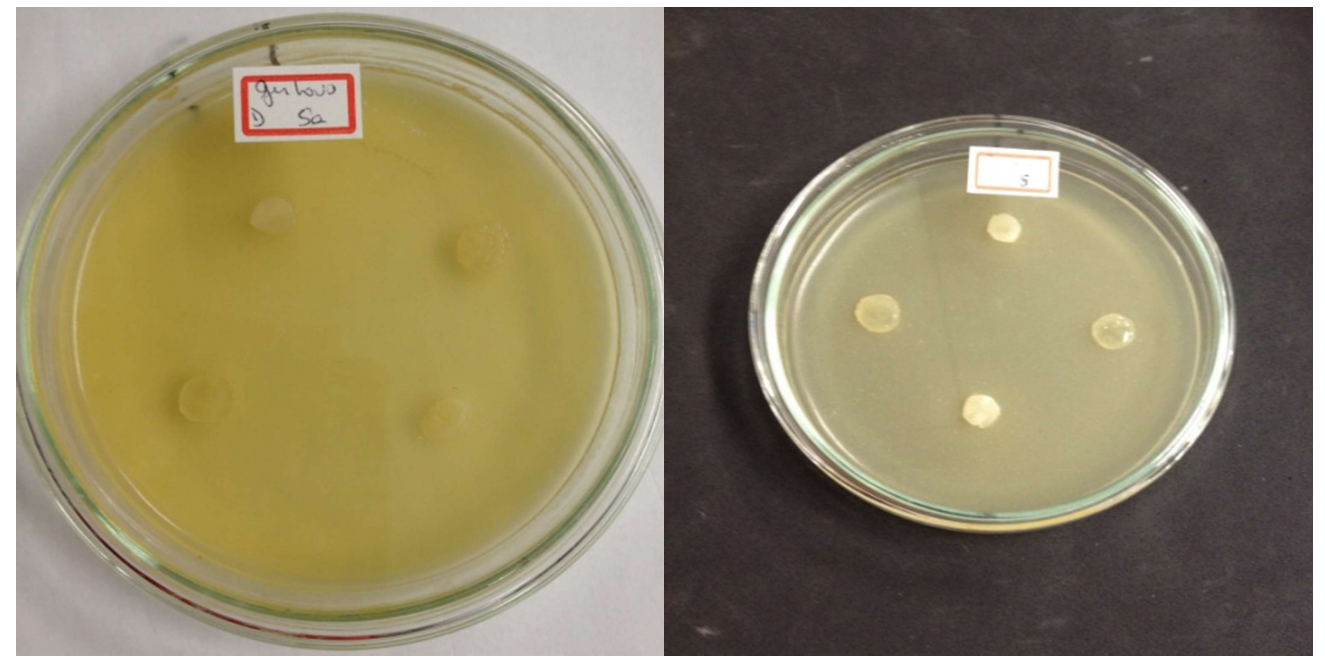

FIGURA 77 - Avaliação das propriedades antimicrobianas dos hidrogéis de PVA contendo papaína e complexo de papaína e $\beta$-ciclodextrina frente a cepa de Staphylococcus aureus (ATCC 6538).

A cepa de Candida albicans também não sofreu nenhum efeito inibitório frente à exposição ao hidrogel (FIGURA 78). Considerando os resultados dos ensaios microbiológicos realizados, destaca-se a ausência de capacidade biocida dos hidrogéis na presença ou ausência de papaína e/ou complexo, indicando que nas concentrações utilizadas $(2 \%, p / p)$ não foi observado nenhum efeito de inibição microbiana.

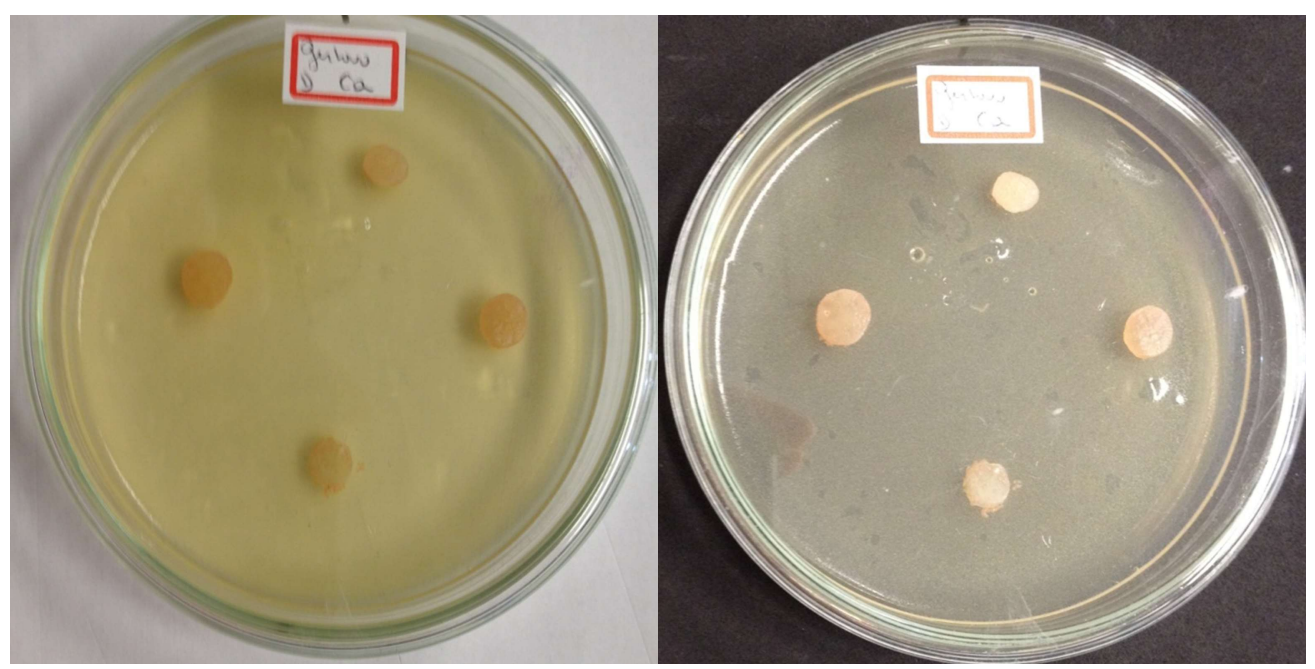

FIGURA 78 - Avaliação das propriedades antimicrobianas dos hidrogéis frente à cepa de Candida albicans (ATCC 10231). 


\section{AVALIAÇÃO DAS PROPRIEDADES DE ADESÃO CELULAR}

$\mathrm{Na}$ busca por identificar a interação entre o hidrogel e seus componentes, com as células da lesão ou ferida, a capacidade de permitir a adesão celular dos sistemas produzidos foi avaliada utilizando fibroblastos. Tal propriedade é de grande relevância para o desenvolvimento de curativos avançados, uma vez que a adesão celular sobre o curativo pode acarretar graves prejuízos aos pacientes e consequentemente dificultar o processo de cicatrização.

O processo de adesão celular é de fato uma ação tempo-dependente, portanto o cultivo foi realizado por 24 horas de modo a garantir tempo necessário para a realização do processo de adesão celular.

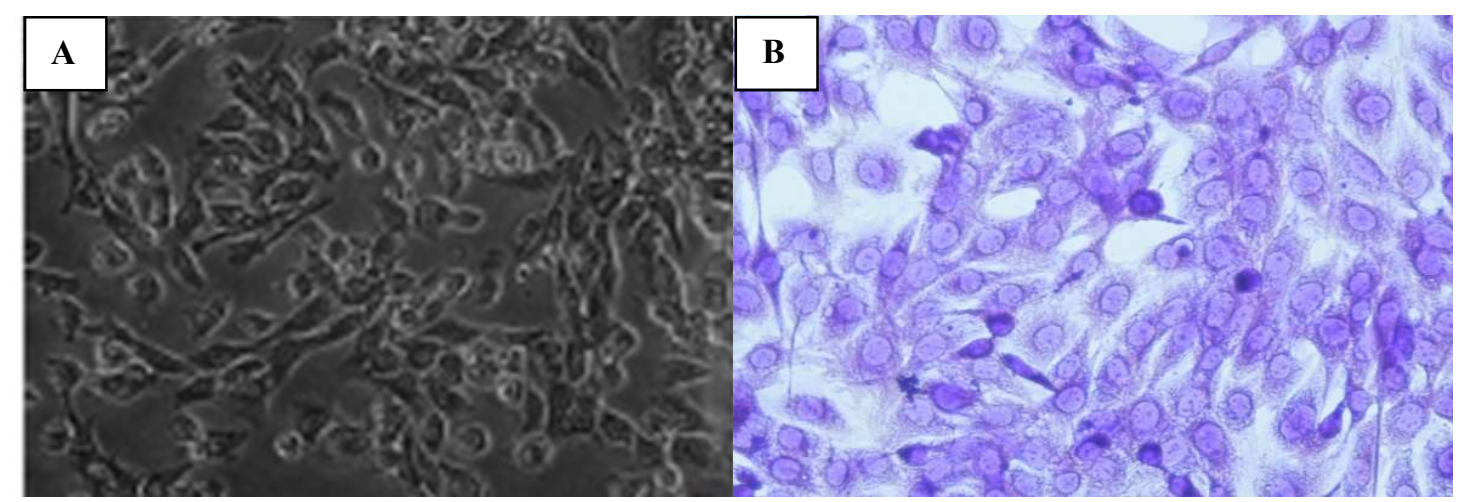

FIGURA 79 - Micrografia obtida por microscopia óptica (aumento de1000x) do controle de fibroblastos utilizados para o teste de adesão celular, considerando que: A - campo escuro; B - campo claro.

O controle de células (FIGURA 79) utilizado correspondeu às células em meio de cultura de modo a permitir a visualização e a contagem das células viáveis empregadas no ensaio, assegurando a viabilidade do mesmo e, permitindo a confirmação da ausência ou não de fibroblastos nos hidrogéis.

Os resultados obtidos por microscopia após cultivo das células sobre os hidrogéis está descrito na FIGURA 80 (A e B) e FIGURA 81 (A e B), onde observamse os hidrogéis sem a presença de células aderidas. 


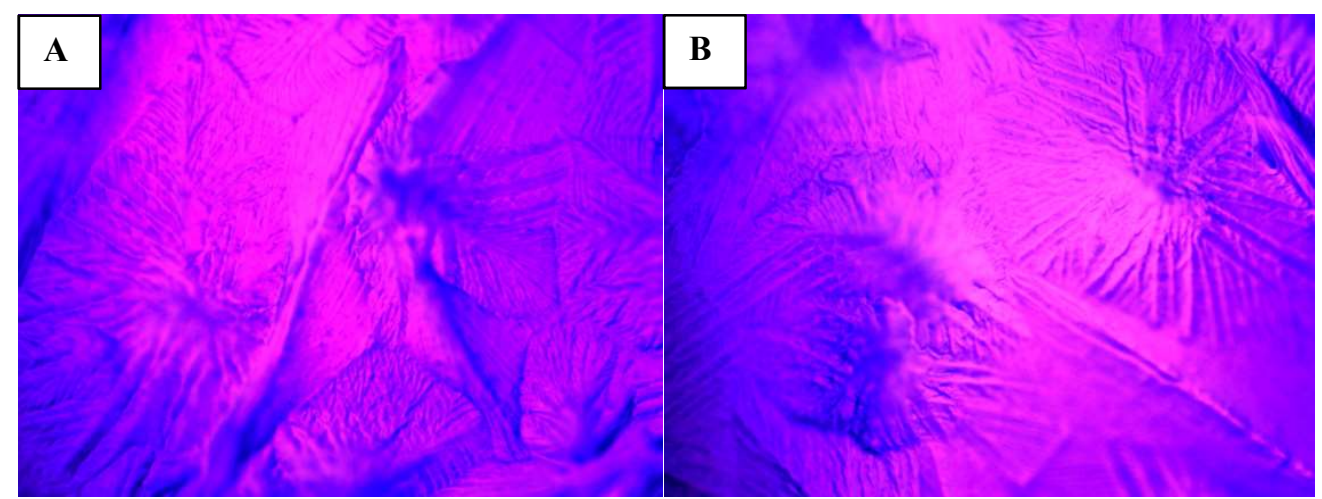

FIGURA 80 - Micrografia obtida por microscopia óptica do hidrogel de PVA sem papaína após 24 horas de contato com as células BALB/c 3T3 para o teste de adesão celular, considerando que: A - utilizando aumento de 1000x; B - utilizando aumento de 4000x.

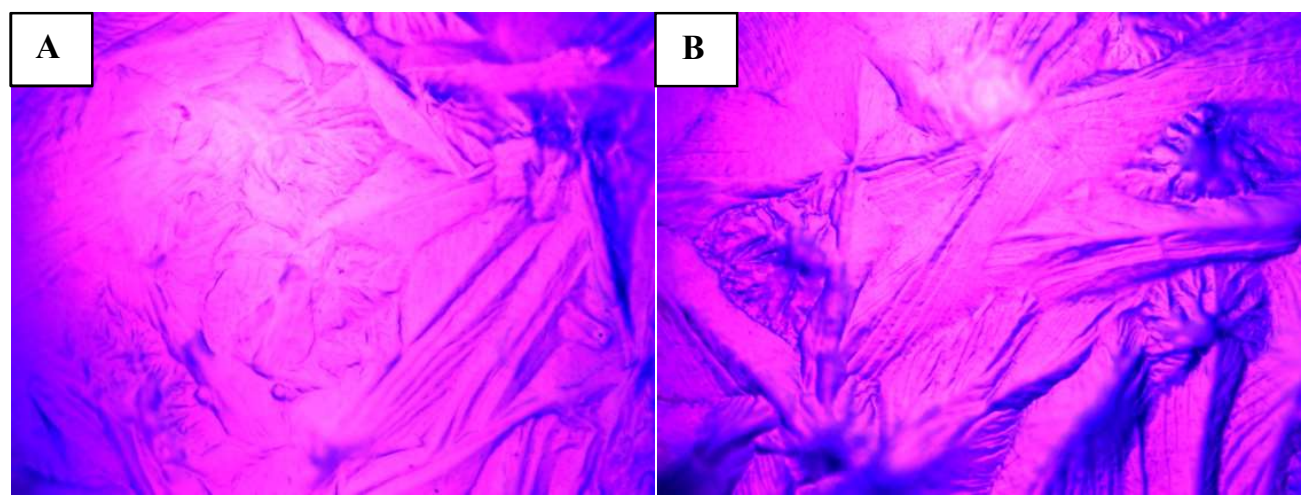

FIGURA 81 - Micrografia obtida por microscopia óptica (aumento de 1500x) do hidrogel à base de PVA após 24 horas de contato com as células BALB/c 3T3 para o teste de adesão celular, considerando que: $\mathbf{A}$ - hidrogel com papaína; $\mathbf{B}$ - hidrogel contendo o complexo.

Apesar do efeito conhecido da papaína sobre a adesão celular, o hidrogel de PVA, contendo ou não papaína em sua composição, não conferiu ambiente propício à adesão e ao crescimento dos fibroblastos. Tal informação é de grande relevância, considerando que o tratamento de queimaduras ou problemas de pele, requer o emprego de agentes ou dispositivos não aderentes, evitando assim problemas na cicatrização, remoção e troca do curativo. 


\section{CONCLUSÃO}

A avaliação in sílico das implicações estruturais da papaína indicou acessibilidade de resíduos-alvo para a formação do complexo, como Triptofano, fenilalanina e tirosina, evidenciando, desta forma, a possibilidade de formação de múltiplos complexos de inclusão entre a ciclodextrina e a papaína.

A formação do complexo acarretou redução da citotoxicidade da papaína, além de diminuir o reconhecimento por anticorpo específico e levar a uma diminuição na produção de citocinas murinas frente ao estímulo com papaína. Outro ponto relevante é que a formação do complexo não exerceu nenhum efeito significativo sobre a atividade proteolítica da papaína. Deste modo, o complexo liofilizado demonstrou adequado para a administração da papaína, com melhor biocompatibilidade e possível redução dos efeitos adversos decorrentes de seu uso tópico, se comparados a enzima isolada.

O emprego da radiação sobre a papaína isolada, objetivando redução dos efeitos imunológicos, apresentou algum efeito quando realizado em solução. A influência do processo de irradiação do complexo e da papaína a uma dose estabelecida de 10 kGy não foi capaz de desencadear alterações na resposta imune por meio da ligação com o anticorpo. No entanto, o doseamento de citocinas, revelou ausência de TNFa e IL-4 e, um pequeno aumento nos níveis de IL-2, IFNy e IL10, sugerindo possível redução da resposta imunogênica da papaína, porém de maneira menos efetiva que a complexação com ciclodextrinas. É relevante destacar que, embora a radiação seja conhecida por alterar e/ou reduzir as propriedades tóxicas e imunogênicas de proteínas e toxinas, tal efeito não se mostrou efetivo no caso da papaína dentro das condições avaliadas.

O hidrogel à base de PVA demonstrou ser uma forma farmacêutica adequada para veiculação do complexo e da papaína isolada por permitir a associação dos processos de cristalização e reticulação, e ainda promover a esterilização causada pela exposição à radiação gama, levando a formação de nanoestrutura adequada para veiculação destas substâncias em concentrações terapêuticas.

Tal sistema, contendo o complexo ou a papaína isolada se mostrou biocompatível e não aderente, além de apresentar integridade física adequada para 
utilização como curativo dérmico, mesmo não apresentando propriedades antimicrobianas frente as cepas estudadas.

Por fim, conclui-se que o desenvolvimento do complexo de papaína e ciclodextrina permitiu uma forma de apresentação biocompatível da enzima associada à possível redução nas reações adversas causadas pelo uso tópico da papaína. Adicionalmente, o hidrogel à base de PVA contendo o complexo de papaína e ciclodextrina desenvolvido apresentou propriedades adequadas para utilização como curativo primário, e, desta forma, constituindo novo dispositivo biomédico promissor para tratamento de feridas e úlceras dérmicas. 


\section{REFERÊNCIAS}

1. LOPES, P. Avaliação da eficácia e segurança da papaína como promotor de absorção cutâneo utilizando técnicas biofísicas e cultura celular de queratinócitos humanos. 2003. Tese (Doutorado) - Universidade de São Paulo, São Paulo.

2. TELGENHOFF, D., LAM, K., RAMSAY, S., VASQUEZ, V., VILLAREAL, K., SLUSAREWICZ, P., ALTAR, P., SHROOT, B. Influence of papain urea copper chlorophyllin on wound matrix remodeling. Wound Repair and Regeneration, v. 15, p. 727-735, 2007.

3. ROSENBERG, L., LAPIDA, O., BOGDANOV-BEREZOVSKYA, A., GLESINGERA, R., KRIEGERA, Y., SILBERSTEIN, E. SAGI, A., JUDKINS, K., SINGER, A. J. Safety and efficacy of a proteolytic enzyme for enzymatic burn debridement: a preliminary report. Burns, v. 30, p. 843-850, 2004.

4. FALABELlA, A. F. Debridement and wound bed preparation. Dermatologic Therapy, v. 19, p. 317-325, 2006.

5. POLLIZI, K., BOMMARIUS, A., BROERING, J., \& CHAPARRO-RIGGERS, J. Stability of biocatalysts. Current Opinion in Chemical Biology, v. 11, p. 220-225, 2007.

6. PIEPER, B., CALIRI, M. H. Nontraditional wound care: A review of the evidence for the use of sugar, papaya/papain, and fatty acids. Journal of Wound, Ostomy and Continence Nursing, v. 30, p. 175-183, 2003.

7. FOOD AND DRUG ADMINISTRATION. Topical drug products containing papain; Enforcement action dates. Department of Health and Human Services, 2008. (FDA - $2008-N-0481)$.

8. KAMPHUIS, I., KALK, K., SWARTE, M., DRENTH, J. Structure of papain refined at 1.65 angstron resolution. Journal of Molecular Biology, v. 179, p. 233-256, 1984.

9. MIYAMOTO, D., WATANABE, J., \& ISHIHARA, K. Highly stabilized papain conjugated with water-soluble phospholipid polymer chain having a reacting terminal group. Journal of Applied Polymer Science, v. 91, p. 827-832, 2004. 
10. KAUL, P., SATHISH, H. A., \& PRAKASH, V. Effect of metal ions on structure and activity of papain from Carica papaya. Nahrung/Food, v. 46, p. 2-6, 2002.

11. EDWIN, F., SHARMA, V., JAGANNADHAM, M. V. Stabilization of molten globule state of papain by urea. Biochemical and Biophysical Research Communications, v. 290, p. 1441-1446, 2002.

12. SATHISH, H., KUMARA, P., PRAKASH, V. Mechanism of solvent induced thermal stabilization of papain. International Journal of Biological Macromolecules, v. 41, p. 383-390, 2007.

13. GEEVER, L., COONEY, C., LYONS, J., KENNEDY, J., NUGENT, M., DEVERY, S., HIGGINBOTHAM, C. L. Characterization and controlled drug release from novel drug-loaded hydrogels. European Journal of Pharmaceutics and Biopharmaceutics, v. 69, p. 1147-1159, 2008.

14. AJJI, Z., OTHMAN, I., ROSIAK, J. Production of hydrogel wound dressings using gamma radiation. Nuclear Instruments and Methods in Physics Research, v. 229, p. 375-380, 2005.

15. HASSAN, C. M., TRAKAMPAN, P., PEPPAS, N. A. Water solubility characteristics of poly(vinyl alcohol) and gels prepared by freezing/thawing processes. Water Soluble Polymers, p. 31-40, 2002.

16. PACIOS, I., PASTORIZA, A., PIEROLA, I. Effect of the crosslinking density and the method of sample preparation on the observed microstructure of macroporous and conventional poly(N,N-dimethylacrylamide) hydrogels. Colloid and Polymer Science, v. 285, p. 263-272, 2006.

17. BYUN, MYUNG-WOO, LEE, JU-WOON, YOOK, HONG-SUN, JO, C., KIMB, HEE-YUN. Application of gamma irradiation for inhibition of food allergy. Radiation Physics and Chemistry, v. 63, n. 3-6, p. 369-370, 2002.

18. WORLD HEALTH ORGANIZATION. High dose irradiation: Wholesomeness of food irradiated with doses above 10 kGy. WHO Technical Report Series 890. Geneva, p. 9-37, 1999. 
19. ROSIAK, J., OLEJNICZAK, J. Medical Application of Radiation Formed Hydrogels. Radiation Physics and Chemistry, v. 42, p. 903-906, 1993.

20. LOFTSSON, T., BREWSTER, M. E. Pharmaceutical applications of cyclodextrins.

1. Drug solubilization and stabilization. Journal of Pharmaceutical Sciences. v. 85, n. 10, p. 1017-1025, 1996.

21. BREWSTER, M.E., LOFTSSON T. Cyclodextrins as pharmaceutical solubilizers. Advanced Drug Delivery Reviews, v. 59, n. 7, p. 645-666, 2007.

22. IRIE, T., UEKAMA, K. Cyclodextrins in peptide and protein delivery. Advanced Drug Delivery Reviews, v. 36, n. 1, p. 101-123, 1999.

23. DESAI, A, LEE, C., SHARMA, L., SHARMA, A. Lysozyme refolding with cyclodextrins: structure-activity relationship. Biochimie, v. 88, n. 10, p.1435-45, 2006.

24. BREWSTER, M.E., HORA, M.S., SIMPKINS, J.W., BODOR, N. Use of 2Hydroxypropyl- $\beta$-cyclodextrin as a solubilizing and stabilizing excipient for protein drugs. Pharmaceutical Research, v. 8, n. 6, p. 792-795, 1991.

25. VARCA, G. H., ANDRÉO-FILHO, N., FRACETO, L. F., KANEKO, T. M., FERRAZ, H. G., ESTEVES, N. M., ISSA, M. G., MATHOR, M. B., LOPES, P. S. Thermal characterization and cytotoxicity of complexes formed by papain and cyclodextrin. Journal of Biological Physics, v. 33, p. 463-475, 2008.

26. O'NEIL, M. The Merck index: An Encyclopedia of Chemicals, Drugs ans Biologicals. 13a. Ed. Whitehouse Station, 2001.

27. KIM, M., YAMAMOTO, D., MATSUMOTO, K., INOUE, M., ISHIDA, T., MIZUNO, H.,SUMIYA, S., KITAMURA, K. Crystal structure of papain-E64-c complex binding diversity of E64c to papain S2 and S3 subsites. Biochemistry Journal, v. 287, p. 797803, 1992.

28. DRENTH, J., JANSONIUS, J., KOEKOEK, R., SWEN, H., WOLTERS, B. Structure of Papain, Nature, v. 218, p. 929-932, 1968.

29. EDWIN, F., JAGANNADHAM, M. V. Single disulfide bond reduced papain exists in a compact intermediate state. Biochemical and Biophysics Acta, v. 1479, p. 6982, 2000. 
30. KILARA, A., SHAHANI, K. M. Preparation and properties of immobilized papain and lipase. Biotechnology and Bioengineering, v. 14, p. 1703-1714, 1977.

31. ARNON, R., Papain. Methods in Enzymology, v. 19, p. 226-244, 1970.

32. AMRY, E., MAMBOYA, F. Papain, a plant enzyme of biological importance: a Review. American Journal of Biochemistry and Biotechnology. v. 2, n. 8, p. 99104, 2012.

33. SCHECHTER, I., BERGER, A. On the size of the active site of proteases. I. Papain. Biochemical and Biophysical Research Communications, v. 27, n. 2, p. 157-62, 1967.

34. KIMMEL, J. R., SMITH, E. L. Crystalline papain: I. preparation, specificity, and activation. Journal of Biological Chemistry, v. 207, p. 515-531, 1954.

35. GRZONKA, Z., FRANCISZEK, K., WICZK., W. Cysteine proteases. Industrial Enzymes, v. 36, p. 181-185, 2007.

36. SELDON, T. A., HUGHES, K. E., MUNSTER, D. J., CHIN, D. Y., JONES, M. L. Improved protein-A separation of VH3 Fab from Fc after papain digestion of antibodies. Journal of Biomolecular Technology, v. 22, n. 2, p. 50-52, 2011.

37. ADAMCZYK, M., GEBLER, J. C., WU, J. Papain digestion of different mouse IgG subclasses as studied by electrospray mass spectrometry. Journal of Immunological Methods, v. 237, n. 1-2, p. 95-104, 2000.

38. Sigma-Aldrich. PAPAIN. Disponível em: http://www.sigmaaldrich.com/lifescience/metabolomics/enzyme-explorer/analytical-enzymes/papain.html. Acesso em: 03/12/2013.

39. KAISER, O., ALIUOS, P., WISSEL, K., LENARZ, T., WERNER, D., REUTER, G., KRAL, A., WARNECKE, A. Dissociated neurons and glial cells derived from rat inferior colliculi after digestion with papain. Plos One, v. 12, n. 8, p. e80490, 2013.

40. Genlantis: NeuroPapain enzyme. Disponível em: http://www.genlantis.com/neuropapain.html Acesso: 02/04/13. 
41. Bio-Rad: ID-Papain. Disponível em: http://www.bio-rad.com/en-uk/product/idpapain Acesso: 02/02/2013

42. Allanfill Enzyme Ointment. Disponível em: http://www.clinicalpharmacology.com/apps/images/photo us h/074/alla101j.jpg. Acesso: 02/10/2014.

43. Accuzyme SE. Disponível em: http://drugster.info/img/drug/121 121 3.jpg. Acesso: 02/10/2014.

44. MARIO ROXAS, N. D. The role of enzyme supplementation in digestive disorders. Alternative Medicine Review, v. 13, n. 4, p. 307-314, 2008.

45. Papain Papaya Enzyme - Swanson. Disponível em: http://www.swansonvitamins.com/swanson-premium-papain-papaya-enzyme-100mg-90-veg-caps Acesso: 02/05/13.

46. WANG, W. Lyophilization and development of solid protein pharmaceuticals. International. Journal of Pharmaceutics, v. 203, p. 1-60, 2009.

47. AFAQ, S, IQBAL, J. Immobilization and stabilization of papain on chelating sepharose: a metal chelate regenerable carrier. Electronic Journal of Biotechnology, v. 4, n. 3, 2001.

48. SAHOO, B., SAHU, S. K., BHATTACHARYA, D., DHARA, D., PRAMANIK, P. A novel approach for efficient immobilization and stabilization of papain on magnetic gold nanocomposites. Colloids and Surfaces B: Biointerfaces, v. 16, n. 101, p. 280-289, 2013.

49. FERRAZ, C. C., VARCA, G. H. C., LOPES, P.S., MATHOR, M. B., LUGÃO, A. B. Radio-synthesized polyacrylamide hydrogels for proteins release. Radiation Physics and Chemistry, v. 94, p. 186-189, 2014.

50. ZULLI, G., LOPES, P. S., LUGAO, A. B., ROGERO, S. O., OSTROSKY, E. A., VELASCO, M. V., BARBARA, M.C.S., MIYAMARU, L. L., MATHOR, M. B. Polymeric matrix development for incorporation and controlled release of papain. Controlled Release Society Newsletter, v. 25, p. 6-7, 2008. 
51. LI, F., XING, Y., DING, X. Immobilization of papain on cotton fabric by sol-gel method Immobilization of papain on cotton fabric by sol-gel method. Enzyme and Microbial Technology, v. 40, n. 7, p. 1692-1697, 2007.

52. Immobilized Papain (Agarose Resin). Disponível em: http://www.piercenet.com/product/immobilized-papain Acesso: 02/03/14.

53. LAD, R. Biotechnology in Personal Care. Cosmetic Science and Technology Series, v. 29. New York: Taylor \& Francis, 2006.

54. Cyclodextrins: Water Structure and Science. Disponível em: http://www1.lsbu.ac.uk/water/cyclodextrin.html Acesso em: 12/04/2013

55. VEIGA, F., PECORELLI, C., RIBEIRO, L. As Ciclodextrinas em Tecnologia Farmacêutica. Coimbra: Minerva Coimbra, 2006.

56. VARCA, G. H. C., ANDRÉO-FILHO, N., LOPES, P. S., FERRAZ, H. G. Cyclodextrins: an overview of the complexation of pharmaceutical proteins. Current Protein and Peptide Science, v. 11, p. 255-263, 2010.

57. HORSKÝ, J., PITHA, J. Inclusion complexes of proteins: Interaction of cyclodextrins with peptides containing aromatic amino acids studied by competitive spectrophotometry. Journal of inclusion phenomena and molecular recognition in chemistry, v. 18, n. 3, p. 291-338, 1994.

58. AACHMANN, F. L., OTZEN, D. E., LARSEN, K. L., WIMMER, R. Structural background of cyclodextrin-protein interactions. Protein Engineering, v. 16, n. 12, p. 905-912, 2003.

59. ULAŃSKI, P.; JANIK, I.; ROSIAK, J. M. Radiation formation of polymeric nanogels. Radiation Physics and Chemistry, v. 52, p. 289-294, 1998.

60. AKIYAMA, Y.; FUJIWARA, T., TAKEDA, S., IZUMI, Y.; NISHIJIMA, S. Preparation of stimuli-responsive protein nanogel by quantum-ray rradiation. Colloid and Polymer Science, v. 285, p. 801-807, 2007.

61. EAGLE, M., ROONEY, P., LOMAS, R., KEARNEY, J. N. Validation of radiation dose received by frozen unprocessed and processed bone during terminal sterilization. Cell Tissue Banking, v. 6, n. 3, p. 221-230, 2005. 
62. CHUAQUI, C., PETKAU, A. Chemical reactivity and biological effects of superoxide radicals. International Journal of Radiation Applications and Instrumentation, v. 30, n. 5-6, p. 365-373, 1987.

63. METODIEWA, D., DUNFORD, H. Spectral studies of intermediate species formed in one-electron reactions of bovine liver catalase at room and low temperatures. A Comparison with Peroxidase Reactions. International Journal of Radiation Biology, v. 62, p. 543-553, 1992.

64. Cadot, P., VAN hOEYVEld, E. M., Ceuppens, J. L., SteVens, E. A. Composition and stability of allergenic extracts made from gamma-irradited rye grass (Lolium perenne) pollen. Clinical and Experimental Allergy, v. 29, n. 9, p. 12481255, 1999.

65. LE CAËR, S. Water Radiolysis: Influence of Oxide Surfaces on H2 Production under lonizing Radiation. Water, v. 3, n. 1, p. 235-253, 2011.

66. GEBICKA, L.; METODIEVA, D.; BACHMA, S. The catalytic and peroxidatic activity of irradiated dilute aqueous solutions of catalase. Journal of Radioanalytical and Nuclear Chemistry, v. 116, p. 77-86, 1987.

67. DAVIES, K. J. A. Protein damage and degradation by oxygen radicals. I. general aspects. Journal of Biological Chemistry, v. 262, p. 9895-9901, 1987.

68. SAHA, A.; MANDAL, P. C.; BHATTACHARYYA, S. N. Radiation-Induced Inactivation of Enzymes - A Review. Radiation Physics and Chemistry, v. 46, n. 1, p.123-145, 1995.

69. ROSIAK J.M. Hydrogel dressings - Radiation Effects on Polymers, ACS Books Washington DC, v. 475, p. 271-299, 1991.

70. Kikgel: Aqual-Gel. Disponível em: http://kikgel.com.pl/?p=114 Acesso em: 07/08/13.

71. WOODS, C. A., JONES, L. W., FONN, D. Comfort and adaptation to silicone hydrogel lenses for daily. Eye \& Contact Lens, v. 34, n. 4, p. 215-223, 2008.

72. Lente de contato de hidrogel de silicone. Disponível em: http://www.optometry.co.uk/clinical/details?aid=1070 Acesso: 09/10/2013. 
73. XING, Q., YATES, K. VOGT, C., QIAN, Z., FROST, M. C., ZHAO, F. Increasing Mechanical Strength of Gelatin Hydrogels by Divalent Metal Ion Removal. Scientific Reports, v. 4, article number: 4706 doi:10.1038/srep04706

74. ISMAIL, H., IRANI, M., AHMAD, Z. Starch-Based Hydrogels: Present Status and Applications. International Journal of Polymeric Materials and Polymeric Biomaterials, v. 62, n. 7, 2013.

75. FOGAÇA, R., ZAMARION, V. M., ARAKI, K., TOMA, H. E., CATALANI, L. H. Hidrogel de PVP/AgNP/papaína para o tratamento de feridas crônicas. $32^{a}$ REUNIÃO ANUAL DA SOCIEDADE BRASILEIRA DE QUÍMICA, Fortaleza, CE, 2009.

76. CLEGG, D. W., COLLYER, A. A. Irradiation effects on polymers. New York, N.Y. Wiley Interscience, 1964.

77. FLORY, P.J. Principles of polymer chemistry. Ithaca, NY, Cornell University Press, 1953.

78. WILLARD, L., RANJAN, A., ZHANG, H., MONZAVI, H., BOYKO, R. F., SYKES, B. D. VADAR: a web server for quantitative evaluation of protein structure quality. Nucleic Acids Research, v. 31, n. 13, p. 3316-3319, 2003.

79. RICHMOND, T. J. Solvent accessible surface area and excluded volume in proteins. Journal of Molecular Biology, v. 178, p. 63-89, 1984.

80. SHRAKE, A., RUPLEY, J. A. Environment and exposure to solvent of protein atoms. Lysozyme and insulin. Journal of Molecular Biology, v. 79, p. 351-364, 1973.

81. RICHARDS, F. M. Areas, Volumes, Packing, and Protein Structure. Annual Reviews of Biophysics and Bioengineering, v. 6, p. 151-176, 1977.

82. Jmol: an open-source Java viewer for chemical structures in 3D. (v. 12.0.4.1.). Disponível em: http://www.jmol.org/.

83. ERLANGER, B. F., KOKOWSKY, N., COHEN, W. The preparation and properties of two new chromogenic substrates of tripsin. Archives of Biochemistry and Biophysics, v. 95, p. 271-278, 1961. 
84. FERRAZ, C. C., VARCA, G. H. C., VILA, M. M. D. C., LOPES, P. S. Validation of in vitro analytical method to measure papain activity in pharmaceutical formulations. International Journal of Pharmacy and Pharmaceutical sciences, v. 6, p. 658-661, 2014.

85. RHEINWALD, J.G., GREEN, H. Formation of keratinizing epithelium in culture by a cloned cell line derived from teratoma. Cell, v. 6, n. 3, p. 317-330, 1975.

86. BARLTROP, J. A., OWEN, T. C. 5-(3-carboxymethoxyphenyl)-2-(4,5dimethylthiazolyl)-3-(-4-sulphophenyl) tetrazolium, inner salt (MTS) and related analogs of 3-(4,5-dimethnthiazolyl)-2,5-diphenyltetrazolium bromide (MTT) reducing to purple water-soluble formazans as cell-viability indicators. Bioorganic \& Medicinal Chemistry Letters, v. 1, n. 1, p. 611-614, 1991.

87. INTERNATIONAL ORGANIZATION FOR STANDARDIZATION. Standard practice for use of the alanine-EPR dosimetry system (ISO/ASTM51607 - 13).

88. KAROLCZAK, S., HODYR, K.; POLOWINSKI, M. Pulse radiolysis system based on ELU-6E LINAC - II. Development and upgrading the system. Radiation Physics and Chemistry, v. 39, p. 1-5, 1992.

89. INTERNATIONAL ORGANIZATION FOR STANDARDIZATION. Sterilization of health care products -- Radiation sterilization -- Substantiation of 25 kGy as a sterilization dose for small or in frequent production batches. American Society for testing and materials, 1996 (ISO/TR 13409:1996).

90. AMERICAN SOCIETY FOR TESTING \& MATERIALS: Standard test methods for determination of gel content and swell ratio of crosslinked ethylene plastics. American Society for testing and materials, 2001 (ASTM D 2765-01).

91. HEWITT, W. Microbiological assay for pharmaceutical analysis: A rational approach. Interpharm/CRC, Press LLC, 2004.

92. INTERNATIONAL ORGANIZATION FOR STANDARDIZATION. Biological testing of medical devices - Tests for in vitro cytotoxicity. Switzerland, 2009 (ISO 10993-5). 
93. MORRIS, A., MACARTHUR, M., HUTCHINSON, E., THORNTON, J. Stereochemical quality of protein structure coordinates. Proteins, v. 12, p. 345-364, 1992.

94. MILLER S., JANIN J., LESK, A.M., CHOTHIA C. Interior and surface of monomeric proteins. Journal of Molecular Biology, v. 196, n. 3, p. 641-656, 1987.

95. WALSH, G. Proteins: Biochemistry and Biotechnology. $2^{\text {nd }}$ ed. Wiley, Blackwel, 2014.

96. LAKOWICZ J. R. Principles of fluorescence spectroscopy. $3^{\mathrm{a}}$ ed. Springer; 2006. Protein fluorescence, p. 529-575.

97. CHALLA, R., AHUJA, A., ALI, J., KHAR, R. K. Cyclodextrins in drug delivery: An updated review. AAPS PharmSciTech, v. 6, n. 2, p. E329-E357, 2005.

98. LOFTSSON, T., JARHO, P., MÁSSON, M., JÄRVINEN, T. Cyclodextrins in drug delivery. Expert Opinion in Drug Delivery. v. 2, n. 2, p. 335-351, 2005.

99. LOFTSSON, T., BREWSTER, M. E. Pharmaceutical applications of cyclodextrins: basic science and product development. Journal of Pharmacy and Pharmacology. v.62, n. 11, p. 1607-1621, 2010.

100. MALEK, T. R., PUGLIESE, A. Low-dose IL-2 as a therapeutic agent for tolerance induction. Immunotherapy, v. 3, n. 11, p. 1281-1284, 2011.

101. HERSHKO, A. Y., SUZUKI, R., CHARLES, N., ALVAREZ-ERRICO, D., SARGENT, J.L., LAURENCE, A., RIVERA, J. Mast cell interleukin-2 production contributes to suppression of chronic allergic dermatitis. Immunity, v. 35 , p. 562-571, 2011.

102. KALLEN, K.J., BÜSCHENFELDE, K.H., ROSE-JOHN, S. The therapeutic potential of interleukin-6 hyperagonists and antagonists. Expert Opinion on Investigation of Drugs, v. 6, n. 3, p. 237-266, 1997.

103. LEONARDO K TEIXEIRA, L.K., FONSECA, B. P. F., BARBOZA, B. A., VIOLA, J. P.B. The role of interferon-gamma on immune and allergic responses. Memórias do Instituto Oswaldo Cruz, v. 100, n. 1, p. 137-144, 2005. 
104. HANIFIN, J. M., SCHNEIDER, L. C., LEUNG, D. Y. M., ELLIS, C.N., JAFFE, H. S., IZU, A. E., BUCALO, L. R., HIRABAYASHI, S.E., TOFTE, S. J., CANTUGONZALES, G., MILGROM, H., BOGUNIEWICZ, M., COOPER, K. D. Recombinant interferon gamma therapy for atopic dermatitis. Journal of The American Academy of Dermatology, v. 28, p. 189-197, 1993.

105. POPA, C., NETEA, M. G., VAN RIEL, PIET L. C. M., VAN DER MEER, JOS W. M., STALENHOEF, A. F. H. The role of TNF- $\alpha$ in chronic inflammatory conditions, intermediary metabolism, and cardiovascular risk. The Journal of Lipid Research, v.48, p. 751-762, 2007.

106. IWAKURA Y1, NAKAE S, SAIJO S, ISHIGAME H. The roles of IL-17A in inflammatory immune responses and host defense against pathogens. Immunological Reviews, v.225, p. 57-79, 2008.

107. NELMS, K., KEEGAN, A. D., ZAMORANO, J., RYAN, J. J., PAUL, W. E. The IL4 receptor: signaling mechanisms and biologic functions. Annual Review of Immunology v. 17, p. 701-738, 1999.

108. URRY, Z. XYSTRAKIS, E., HAWRYLOWICZ, C. M. Interleukin-10-secreting regulatory T cells in allergy and asthma. Current Allergy and Asthma Reports, v.6, n. 5, p. 363-371, 2006.

109. NORTON, S. K., BARNSTEIN, B., BRENZOVICH, J., BAILEY, D.P., KASHYAP, M., SPEIRAN, K., FORD, J., CONRAD, D. WATOWICH, S., MORALLE, M.R., KEPLEY, C.L., MURRAY, P.J., RYAN, J. IL-10 Suppresses mast cell IgE receptor expression and signaling in vitro and in vivo. Journal of Immunology, v. 180, p. 28482854, 2008.

110. LAL, M. Radiation Induced Oxidation of Sulphydryl Molecules in Aqueous Solutions. A Comprehensive Review. Radiation Physics and Chemistry, v. 43, n. 6 , p. 595-611, 1994.

111. ALVES, M. H., JENSEN, B. E., SMITH, A. A., ZELIKIN, A. N. Poly(vinyl alcohol) physical hydrogels: new vista on a long serving biomaterial. Macromolecular Bioscience, v. 11, n10, p. 1293-1313, 2011. 
112. CHOWDHURY, M. N., ALAM, A. K., DAFADER, N. C., HAQUE, M. E., AKHTAR, F., AHMED, M. U., RASHID, H., BEGUM, R. Radiation processed hydrogel of poly (vinyl alcohol) with biodegradable polysaccharides. Bio-medical Materials and Engineering, v. 16, n. 3, p.223-228, 2006.

113. HOARE, T. R., KOHANE, D. S. Hydrogels in drug delivery: Progress and challenges. Polymer, v.49, n. 8, p. 1993-2007, 2008.

114. KHOURY, C. H. R., ADALSTEINSSON, T. H., JOHNSON, B., CRONE, W. C., BEEBE, D. J. Tunable microfabricated hydrogels - A study in protein interaction and diffusion. Biomedical Microdevices, v.5, n. 1, p. 35-45, 2003.

115. HOMAEI, A. A., SAJEDI, R. H., SARIRI, R., SEYFZADEH, S., STEVANATO, R. Cysteine enhances activity and stability of immobilized papain. Amino Acids, v. 38, n. 3, p. 937-942, 2010. 